

\section{TEKNOLOGI, INFORMASI, DAN KOMUNIKASI \\ (PRINSIP DAN APLIKASI DALAM STUDI PEMIKIRAN ISLAM)}

\section{Penulis}

Eni Fariyatul Fahyuni, S.Psi, M.Pd.I

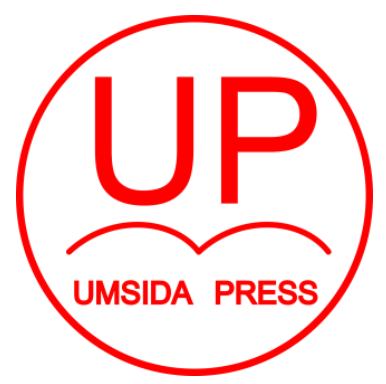

Diterbitkan oleh

UMSIDA PRESS

Jl. Mojopahit 666 B Sidoarjo

ISBN: 978-979-3401-60-7

Copyright@2017.

Authors

All rights reserved

1 |Teknologi, Informasi, dan Komunikasi 
TEKNOLOGI, INFORMASI, DAN KOMUNIKASI

(PRINSIP DAN APLIKASI DALAM STUDI PEMIKIRAN ISLAM)

Penulis :

Eni Fariyatul Fahyuni, S.Psi, M.Pd.I

\section{ISBN :}

978-979-3401-60-7

\section{Editor :}

Septi Budi Sartika, M.Pd

M. Tanzil Multazam, S.H., M.Kn.

\section{Copy Editor :}

Fika Megawati, S.Pd., M.Pd.

\section{Design Sampul dan Tata Letak :}

Mochamad Nashrullah, S.Pd

\section{Penerbit :}

UMSIDA Press

\section{Redaksi :}

Universitas Muhammadiyah Sidoarjo

J1. Mojopahit No 666B

Sidoarjo, Jawa TImur

\section{Cetakan pertama, Agustus 2017}

C Hak cipta dilindungi undang-undang Dilarang memperbanyak karya tulis ini dengan suatu apapun tanpa ijin tertulis dari penerbit.

2 |Teknologi, Informasi, dan Komunikasi 


\section{Kata Pengantar}

Puji syukur penyusun panjatkan kehadirat Allah Swt, karena hanya atas rahmad, hidayah serta inayahNya buku ajar mahasiswa yang berjudul "Teknologi, Informasi, dan Komunikasi (Prinsip dan Aplikasi dalam Studi Pemikiran Islam)" dapat terselesaikan dengan baik. Buku ajar ini disusun dan dibuat berdasarkan materi-materi yang ada yang bertujuan agar dapat menambah pengetahuan dan wawasan siswa dalam belajar serta agar siswa juga dapat memahami nilai-nilai dasar Islami yang dikembangkan manusia dalam berpikir dan bertindak.

Buku ajar ini membantu memahami sistem informasi yang dimulai dari perkembangan komputer, karena sistem informasi saat ini tidak bisa lepas dari perkembangan komputer. Selain itu beberapa konsep yang terdapat dalam sistem informasi juga dibahas dalam buku ini. Buku ajar ini lebih khusus diperuntukkan kepada para mahasiswa Universitas Muhammadiyah Sidoarjo yang sedang mengambil mata kuliah pembelajaran ICT atau mahasiswa universitas lainnya yang juga mempelajari mata kuliah yang serupa. Oleh karena itu beberapa contoh dan latihan yang ada pada buku ajar ini sebagian diambil dari dunia kemahasiswaan. Mudah-mudahan dengan mempelajari buku ini, para siswa akan mampu menghadapi masalah-masalah atau kesulitan-kesulitan yang timbul dalam pembelajaran dan dengan harapan semoga siswa mampu berinovasi dan berkreasi dengan potensi yang dimiliki.

Kami menyadari bahwa dalam pembuatan buku ajar Teknologi Informasi dan Komunikasi ini masih terdapat

3 | Teknologi, Informasi, dan Komunikasi 
kekurangan sehingga penulis berharap saran dan kritik dari pembaca sekalian agar penulis dapat meningkatkan dan memperbaiki penyajian materi yang lebih baik dari sebelumnya. Akhir kata penulis ucapkan terima kasih.

Sidoarjo, 6 Agustus 2017

Penulis

4 | Teknologi, Informasi, dan Komunikasi 


\section{DAFTAR ISI}

Cover

Identitas Buku

Kata Pengantar

Daftar isi

BAB I Teknologi dan Media Pembelajaran......................... 1

A. Posisi dan Fungsi Teknologi dan Media Pembelajaran .3

B. Landasan media pembelajaran ................................ 17

C. Karakteristik Media Pembelajaran............................27

D. Media Pembelajaran Dua Dimensi...........................29

E. ICT dalam Pembelajaran Inovatif ............................. 33

F. Profesionalitas Guru dalam Pembelajaran ................... 37

Rangkuman dan Soal ..................................................4 49

BAB II Memadukan Teknologi Dan Media Pembelajaran ...51

A. Karakteristik Pemrosesan Informasi ........................52

B. Strategi pembelajaran.......................................... 3

C. Media pembelajaran inovatif....................................5

D. Klasifikasi Bahan Ajar. ........................................6

Rangkuman dan Soal ...................................................9

BAB III Komunikasi Dalam Pembelajaran Berbasis ICT .... 11

A. Komunikasi dan Pembelajaran................................ 12

B. Proses Komunikasi dalam Pembelajaran .................... 16

C. Komunikasi Efektif dalam Pembelajaran...................21

D. Strategi Komunikasi Pembelajaran .............................38

5 | Teknologi, Informasi, dan Komunikasi 
Rangkuman dan Soal

BAB IV Media Pembelajaran Kontekstual Berbasis TIK ....47

A. Media Pembelajaran Berbasis Komputer......................48

B. Strategi Pembelajaran Dengan TIK …………...............51

C. Pemanfaatan Microsoft Power Point untuk

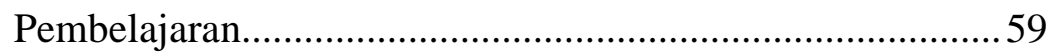

D. Inovasi Teknologi Informasi dan Komunikasi..............63

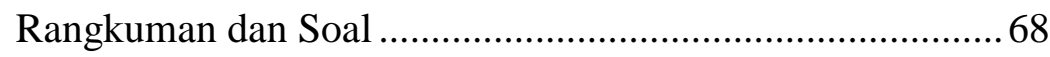

BAB V Media Pembelajaran Berbasis E-Learning ............... 71

A. Pemanfaatan Media E-learning ...................................... 72

B. Teknologi Penunjang E-learning...................................75

C. Pengajaran Berbasis Web............................................... 80

D. IT Pembelajaran Berbasis Multimedia...........................84

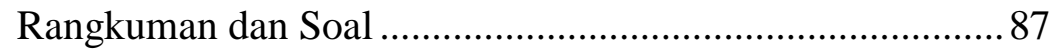

BAB VI Pemanfaatan Media Pembelajaran ........................... 89

A. Penggunaan Media Tidak Terprogram............................90

B. Penggunaan Media Terprogram .....................................91

C. Multimedia dalam Pembelajaran.....................................94

D. Prinsip-prinsip Multimedia ............................................ 100

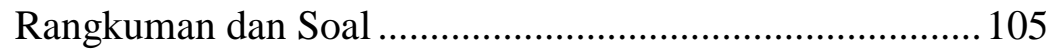

BAB VII Belajar Dengan Piranti Audio, Visual dan

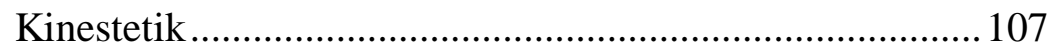

A. Media Pembelajaran Visual ......................................... 108

6 | Teknologi, Informasi, dan Komunileasi 
B. Fungsi Media Pembelajaran Visual .............................112

C. Manfaat Media Pembelajaran Visual ........................... 115

D. Jenis-jenis Media Pembelajaran Visual ...................... 116

E. Prinsip-prinsip Penggunaan Media Pembelajaran

Visual

F. Kriteria Pemilihan Media Visual ................................ 121

G. Pemanfaatan Media Audio dan Radio........................ 122

H. Media Pembelajaran Kinestetik .................................. 127

Rangkuman dan Soal ....................................................... 132

BAB VIII Orientasi Pembelajaran Abad 21 ........................ 134

A. Orientasi Baru Dunia Pendidikan................................. 135

B. Paradigma Pendidikan Abad-21 .................................. 138

C. Pembelajaran Berbasis Blended Learning .................. 141

D. Mengembangkan Kecakapan Siswa............................ 145

E. Pembelajaran Berbasis Teknologi Informasi .............. 149

F. Pembelajaran Secara Tatap Muka dan Virtual............ 153

G. Kompetensi Profesi Guru berbasis ICT .................... 156

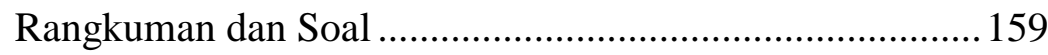

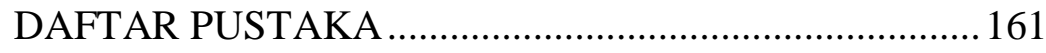

7 | Teknologi, informasi, dan Komunikasi 


\section{DAFTAR TABEL}

Table 1. Strategi mengolah materi berbasis komputer 51 Table 2. Tiga Pandangan Multimedia 96

Table 3 Pandangan tentang Desain Multimedia 98

8 |Teknologi, Informasi, dan Komuníkasi 


\section{DAFTAR GAMBAR}

Gambar 1. Interaksi siswa dengan media pembelajaran $\quad 8$

Gambar 2. Fungsi media dalam proses pembelajaran 12

Gambar 3. Posisi media dalam pembelajaran 13

Gambar 4. Kompleksitas proses pembelajaran 14

Gambar 5. Kerucut pengalaman Dale 22

Gambar 6. Interaksi penggunaan media pembelajaran $\quad 24$

Gambar 7. Bentuk layar atau screen OHP 31

Gambar 8. Berbagai bentuk media papan 31

Gambar 9. Berbagai bentuk media cetak 32

Gambar 10. Perkembangan teknologi, informasi, dan

komunikasi

Gambar 11. Komponen kompetensi guru 41

Gambar 12. Interaksi edukatif guru dan siswa 45

Gambar 13. Sistem blended learning 46

Gambar 14. Prinsip-prinsip multimedia learning 1

Gambar 15. Lingkungan sebagai sumber belajar 2

Gambar 16. Proses pembelajaran $\quad 15$

Gambar 17. Media pembelajaran berbasis komputer $\quad 49$

Gambar 18. Taksonomi komputer dalam pendidikan $\quad 54$

Gambar 19. Strategi pembelajaran peserta didik 59

Gambar 20. Microsoft Power Point 61

Gambar 21. Perkembangan teknologi dalam aspek kehidupan62

Gambar 22. Pembelajaran dengan power point 65

Gambar 23. Komponen e-learning $\quad 72$

Gambar 24. Jaringan internet yang dapat diakses untuk $\begin{array}{ll}\text { pembelajaran } & 74\end{array}$

Gambar 25. Karakteristik Pemanfaatan E-learning 76

Gambar 26. Pembelajaran Berbasis Web 81

Gambar 27. Media pembelajaran visual 109

g|Teknologi, informasi, dan Komunikasi 
Gambar 28. Ragam media pembelajaran visual 110

Gambar 29. Kombinasi penggunaan media pembelajaran 113

Gambar 30. Sistem pengolah informasi tradisional $\quad 117$

Gambar 31. Proses komunikasi visual 119

Gambar 32. Pembelajaran melalui media audio 125

Gambar 33. Belajar dengan kinestetik 129

Gambar 34. Belajar melalui kegiatan outbound $\quad 130$

Gambar 35. Siklus blended learning 137

Gambar 36. Ketrampilan pengetahuan Abad $21 \quad 139$

Gambar 37. Aktifitas Pembelajaran Berbasis Virtual dan

Tatap Muka 154

Gambar 38. Komunikasi antar peserta pada diskusi virtual 156 


\section{BAB I \\ Teknologi dan Media Pembelajaran}

$\mathrm{Bab}$ ini akan menjelaskan pentingnya teknologi dan media dalam proses belajar mengajar. Belakangan ini ketika sebagian besar orang-orang mendengar kata teknologi, mereka memikirkan dengan benda-benda seperti komputer, pemutar MP3, dan pesawat ulang alik. Kata teknologi selalu memiliki berbagai penafsiran, mulai dari sekedar piranti keras hingga cara yang sistematis dalam menyelesaikan masalah. Banyak pendidik beranggapan bahwa teknologi merupakan seluruh solusi pengajaran di dalam kelas. Komputer dan teknologi lainnya tidak membuat guru menjadi lebih bisa. Pada akhirnya gurulah yang harus memiliki beragam pengalaman kaitannya dengan proses pembelajaran di kelas. Kemajuan teknologi memainkan peranan penting dalam pendidikan. Teknologi dan media yang telah dirancang dan disesuaikan dengan kebutuhan peserta didik sehingga membantunya meraih potensi tertinggi mereka, terlepas dari apapun kemampuan bawaan yang mereka bawa sejak lahir. Bab ini menyajikan ringkasan mengenai arti, posisi dan fungsi teknologi dan media pembelajaran yang diharapkan

1 | Teknologi, Informasi, dan Komunikasi 
dapat berperan sebagai salah satu pendukung para guru untuk menuju pemenuhan tuntutan profesionalisme.

Bab ini memberikan perhatian khusus pada fungsi dan karakteristik teknologi dan media pembelajaran inovatif, diantaranya.

Posisi dan Fungsi Media Pembelajaran

Landasan Media Pembelajaran

Karakteristik Media Pembelajaran

Media Pembelajaran Dua Dimensi

ICT dalam Pembelajaran Inovatif

Profesionalitas Guru dalam Pembelajaran

2 | Teknologi, Informasi, dan Komunikasi 


\section{A. Posisi dan Fungsi Teknologi dan Media Pembelajaran}

Peran guru dan siswa dalam proses pembelajaran jelas berubah-ubah karena adanya pengaruh teknologi. Guru dan buku teks tidak lagi menjadi sumber belajar satu-satunya yang utama dan tidak ada bandingannya. Guru telah berubah peran menjadi seorang fasilitator pemerolehan informasi. Bahkan dengan beberapa tombol keyboard, para pelajar dapat menjelajahi berbagai informasi dunia, memperoleh akses dari perpustakaan dan sekumpulan informasi penting lainnya untuk mendapatkan pengetahuan dan ketrampilan barunya.Fenomena yang terjadi di kalangan masyarakat yang memandang bahwa tugas guru hanya seorang pengajar (pentransfer ilmu) di lingkungan pendidikan perlu untuk dirubah. Karena sejatinya seorang guru bukan hanya sebagai pengajar untuk mencerdaskan pola pemikiran anak didik yang dari tidak tahu menjadi tahu. Akan tetapi penting untuk dijelaskan tugas seorang guru yang sebenarnya dari aspek AlQur'an dan hadits. Tugas seorang guru yang pertama dan terpenting adalah pengajar (murabbiy, mu'allim). Firman Allah dalam surat An-Nahl (103) berikut ini.

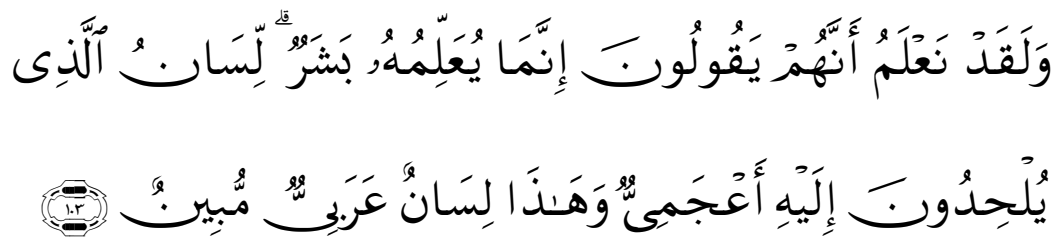

"Sesungguhnya Kami mengetahui bahwa mereka berkata: "Sesungguhnya Al Quran itu diajarkan oleh seorang

3 | Teknologi, Informasi, dan Komunikasi 
manusia kepadanya (Muhammad)". Padahal bahasa orang yang mereka tuduhkan (bahwa) Muhammad belajar kepadanya bahasa 'Ajam, sedang Al Quran adalah dalam bahasa Arab yang terang".

Belajar adalah suatu aktifitas di mana terdapat sebuah proses dari tidak tahu menjadi tahu, tidak mengerti menjadi mengerti, tidak bisa menjadi bisa untuk mencapai hasil yang optimal. Jadi belajar merupakan perubahan yang relatif permanen dalam perilaku atau potensi perilaku sebagai hasil dari pengalaman atau latihan yang diperkuat. Belajar merupakan suatu usaha sadar yang dilakukan oleh individu dalam perubahan tingkah lakunya baik melalui latihan dan pengalaman yang menyangkut aspek kognitif, afektif dan psikomotor untuk memperoleh tujuan tertentu. Menurut paham konstruktivistik, belajar merupakan hasil konstruksi sendiri (pebelajar) sebagai hasil interaksi dengan lingkungan belajarnya. Berdasarkan paradigma konstruktivisme tentang belajar tersebut, maka prinsip media mediated instruction menempati posisi cukup strategis dalam rangka mewujudkan proses belajar yang optimal. Ivent belajar yang optimal merupakan salah satu indikator untuk mewujudkan hasil belajar peserta didik yang optimal pula. Hasil belajar yang optimal juga merupakan cerminan hasil pendidikan yang berkualitas. Pendidikan berkualitas memerlukan sumber daya guru yang mampu dan siap berperan secara profesioanal dalam lingkungan sekolah dan masyarakat. Dalam era perkembangan Iptek yang begitu pesat ini, profesionalisme tidak cukup hanya dengan kemampuan membelajarkan siswa, tetapi juga harus mampu mengelola informasi dan lingkungan untuk memfasilitasi kegiatan belajar siswa 4 | Teknologi, Informasi, dan Komunikasi 
Setiap guru mempunyai keterbatasan dalam menyajikan materi pelajaran kepada para siswanya karena berbagai sebab, seperti: konsep yang abstrak, objek yang berbahaya, objek yang tidak terlihat secara kasat mata, dan biaya yang sangat mahal. Berbagai keterbatasan tersebut dapat diatasi antara lain dengan pemanfaatan teknologi informasi dan komunikasi (TIK) dalam rangka untuk mencapai tujuan pembelajaran. Islam memandang manusia sebagai mahluk yang dilahirkan dalam kaadaan fitrah atau suci, Tuhan memberi potensi yang bersifat jasmaniah dan rohaniah yang didalamnya terdapat bakat untuk belajar dan mengembangkan ilmu pengetahuan dan teknologi untuk kemaslahatan mansia itu sendiri. Sebagaimana firman Allah dalam Q.S Al-Baqarah ayat 31-33

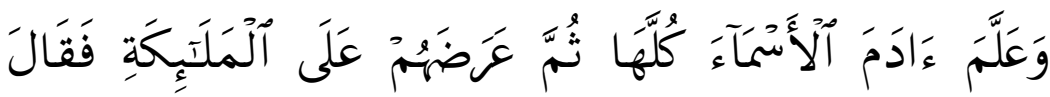

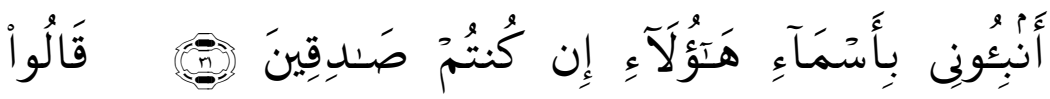

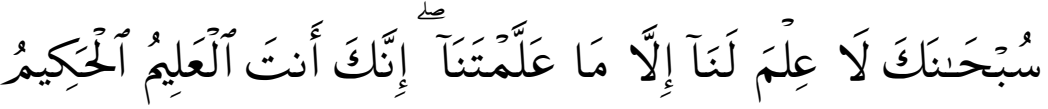

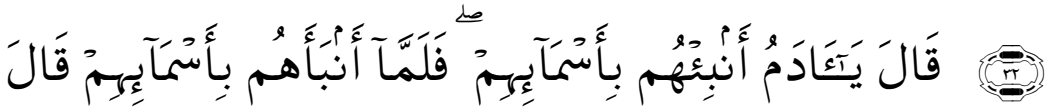

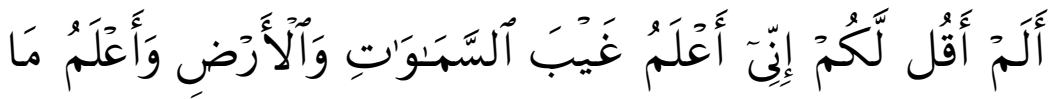
تُبْدُونَ وَمَا كُنتمُ تَكَتُهُونَ نَ 5 | Teknologi, Informasi, dan Komunikasi 
"Dia mengajarkan kepada Adam Nama-nama (benda) seluruhnya, kemudian mengemukakannya kepada Para Malaikat lalu berfirman: "Sebutkanlah kepada-Ku nama benda-benda itu jika kamu memang orang-orang yang benar!"Mereka menjawab: "Maha suci Engkau, tidak ada yang kami ketahui selain dari apa yang telah Engkau ajarkan kepada kami; Sesungguhnya Engkaulah yang Maha mengetahui lagi Maha Bijaksana." "Allah berfirman: "Hai Adam, beritahukanlah kepada mereka Nama-nama benda ini." Maka setelah diberitahukannya kepada mereka Namanama benda itu, Allah berfirman: "Bukankah sudah Ku katakan kepadamu, bahwa Sesungguhnya aku mengetahui rahasia langit dan bumi dan mengetahui apa yang kamu lahirkan dan apa yang kamu sembunyikan?"

Ayat diatas menjelaskan bahwa guru sebagai penggiat pembelajaran memiliki peran yang penting terhadap proses optimalisasi diri siswa untuk menghasilkan perubahan prilaku yang relatif permanent, berdasarkan alasan itulah seorang guru hendaknya mampu merencanakan serta menciptakan suasana atau lingkungan belajar secara kondusif bagi siswasiswanya. Namun, yang perlu digaris bawahi adalah bahwa guru bukanlah satu-satunya sumber belajar, dengan posisinya sebagai penggiat tadi ia pun harus mampu merencanakan serta menciptakan sumber-sumber belajar yang lainnya. Sumber itulah yang nantinya dapat dijadikan sebagai penyalur atau penghubung pesan ajar yang diadakan dan atau diciptakan secara terencana oleh para guru atau pendidik, sumber tersebut biasa dikenal sebagai media pembelajaran. Media pembelajaran dijadikan sebagai penghubung antara guru dan siswa agar tercipta komunikasi yang efektif. Sebagaimana firman Allah dalam Q.S. Yusuf (2)

6 | Teknologi, Informasi, dan Komunikasi 


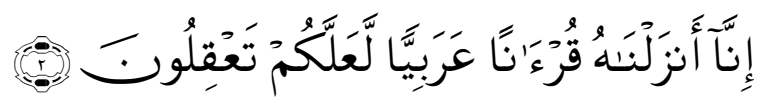

"Sesungguhnya Kami menurunkannya berupa Al Quran dengan berbahasa Arab, agar kamu memahaminya".

Ayat diatas menjelaskan secara detail bahwa menelaah Al-Qur'an yang berbahasa Arab dapat mengembangkan pemetaan pikiran seseorang, sedangkan pikiran yang terpetakan secara baik menjadi embrio bagi kemampuan seseorang dalam mencari dan memecahkan persoalan. Dalam hal ini, membaca dan menelaah Al-Qur'an bukan hanya mencerdaskan hati, melainkan mencerdaskan akal-rasional. Dalam dunia pendidikan, seorang guru muslim seyogyanya menjadikan Al Qur'an sebagai pedoman dalam mengajar. Menjadikannya sebagai referensi awal dalam segala hal yang akan ia ajarkan. Karena sesungguhnya Al Qur'an merupakan sebuah kitab yang universal dalam menerangkan segala persoalan, termasuk didalamnya mengenai media dalam pendidikan. Menurut Zakiah Daradjat, media pendidikan atau pembelajaran adalah suatu benda yang dapat diindrai, khususnya penglihatan dan pendengaran, baik yang terdapat di dalam maupun di luar kelas, yang digunakan sebagai alat bantu penghubung (media komunikasi) dalam proses interaksi belajar mengajar untuk meningkatkan efektivitas hasil belajar siswa (Zakiah Daradjat, 1995).

7 | Teknologi, informasi, dan Komunikasi 


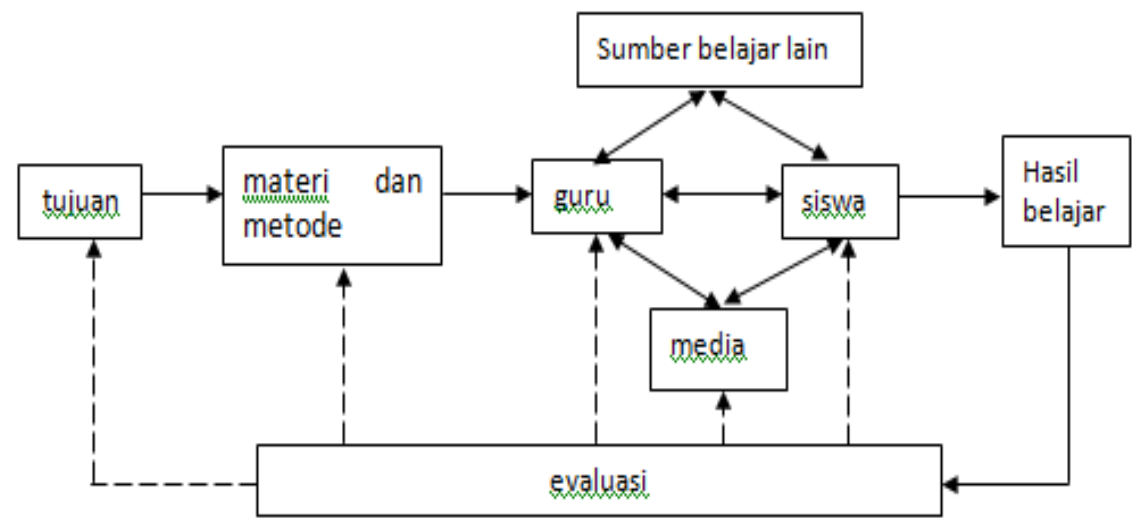

\section{Gambar 1. Interaksi siswa dengan media pembelajaran}

Dalam kegiatan interaksi antara siswa dengan lingkungan di atas, fungsi media dapat diketahui berdasarkan adanya kelebihan media dan hambatan yang mungkin timbul dalam proses pembelajaran. Dalam proses pembelajaran, media memiliki fungsi sebagai pembawa informasi dari sumber (guru) menuju penerima (siswa). Sedangkan metode adalah prosedur untuk membantu siswa dalam menerima dan mengolah informasi guna mencapai tujuan pembelajaran. Upaya dalam meningkatkan mutu pendidikan di Indonesia adalah melalui proses kegiatan belajar mengajar. Menurut Sadiman (1993) proses belajar mengajar pada hakekatnya adalah proses komunikasi, yaitu proses menyampaikan informasi dari sumber pesan melalui saluran atau media tertentu kepada penerima pesan. Pesan-pesan tersebut berupa nilai-nilai ajaran yang dituangkan dalam kurikulum dan disampaikan oleh guru atau sumber lain ke dalam simbolsimbol komunikasi visual maupun verbal. Dengan adanya 8 |Teknologi, Informasi, dan Komunikasi 
media pada proses belajar mengajar, diharapkan dapat membantu guru dalam meningkatkan prestasi belajar siswa.

Gerlach dan Ely yang dikutip Mulyono (2003) mengemukakan media pembelajaran dapat dimaknai secara luas dan sempit. Secara luas, media diartikan sebagai setiap orang, materi atau peristiwa yang dapat memberikan kesempatan kepada seiap individu untuk memperoleh pengetahuan, keterampilan dan sikap. Sedang dalam arti sempit, media pembelajaran adalah sarana non personal yang digunakan oleh guru untuk mendukung proses belajar mengajar agar mencapai kompetensi. Karakteristik dan kemampuan masing-masing media perlu diperhatikan oleh guru agar mereka dapat memilih media mana yang sesuai dengan kondisi dan kebutuhan. Media pembelajaran menempati posisi yang cukup penting sebagai salah satu komponen sistem pembelajaran. Tanpa media, proses pembelajaran sebagai proses komunikasi juga tidak akan bisa berlangsung secara optimal.

Hal demikian dapat kita pelajari dari kisah Nabi Adam yang diajarkan Allah untuk menguasai simbol sebagai sarana berfikir (termasuk menganalisis), dan dengan simbul itu ia bisa berkomunikasi menerina tranformasi pengetahuan, ilmu, internalisasi nilai dan sekaligus melakukan telaah ilmiah. Jadi proses Nabi Adam mulai dari tahap penciptaan awal manusia telah sampai pada tahap praekplorasi fenomena alam, yakni dengan kemampuan mengenali sifat, karakteristik dan perilaku alam. Hal ini bisa kita perhatikan pernyataan ayat 31 al-Maidah:

9 | Teknologi, informasi, dan Komunikasi 


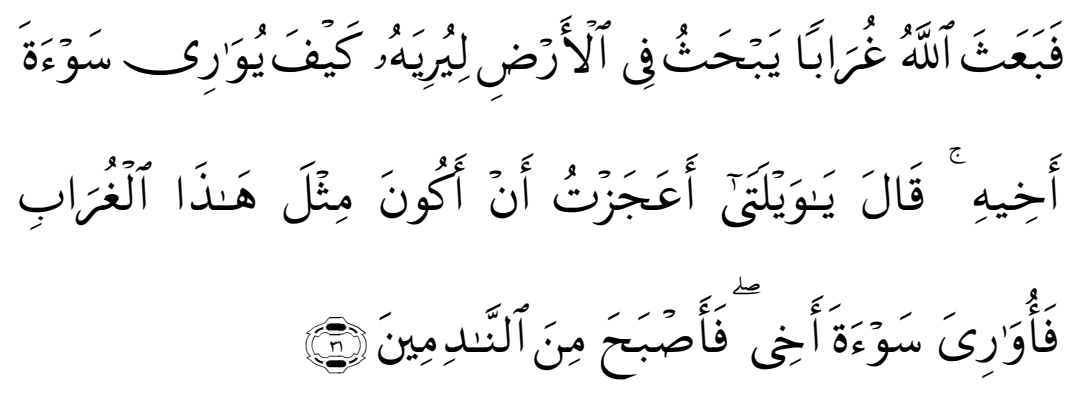

"Kemudian Allah menyuruh seekor burung gagak menggaligali di bumi untuk memperlihatkan kepadanya (Qabil) bagaimana seharusnya menguburkan mayat saudaranya. berkata Qabil: "Aduhai celaka Aku, mengapa aku tidak mampu berbuat seperti burung gagak ini, lalu aku dapat menguburkan mayat saudaraku ini?" karena itu jadilah Dia seorang diantara orang-orang yang menyesal".

Dari penjelasan ayat tersebut, dapat disimpulkan bahwa belajar dan pembelajaran merupakan aktivitas yang melekat secara inhern dalam diri manusia. Alasan inilah manusia dianugrahi potensi oleh Allah Swt untuk belajar dan mengajar sebagai bagian yang tak terpisah dengan tugas yang diembannya. Oleh karena itu Islam sebagai agama menegaskan bahwa belajar merupakan kewajiban bagi setiap muslim.

Berdasarkan beberapa pengertian yang telah dibahas dia atas, media pembelajaran penting digunakan sebagai sarana alat yang dapat merangsang pikiran, perasaan, perhatian, dan minat siswa sehingga akan terjadi proses belajar yang berkualitas untuk mencapai kompetensi peserta didik yang diharapkan. Media merupakan salah satu komponen

10 | Teknologi, Informasi, dan Komunikasi 
komunikasi, yaitu sebagai pembawa pesan dari komunikator menuju komunikan.

Dalam Al-Qur'an, banyak sekali ayat yang memerintahkan manusia untuk selalu menggunakan akal dan memahami serta merenungi segala ciptaan dan kebesaran Allah di alam ini.

"Maka apakah mereka tidak memperhatikan unta bagaimana dia diciptakan. Dan langit, bagaimana ia ditinggikan. Dan gunung-gunung ditegakkan. Dan bumi bagaimana ia dihamparkan". (Q.S.Al-Ghasyiah: 17-20)

Ayat diatas tentunya sejalan dengan yang diungkapkan Daryanto (2010) bahwa kedudukan media pembelajaran sangat penting untuk merangsang pikiran, perhatian dan juga minat belajar siswa, untuk itu perlu diperhatikan berbagai hal dalam pemilihan media, antara lain: 1) pemilihan media yang tepat dapat menarik perhatian siswa dan memberikan kejelasan obyek yang diamati, dan 2) bahan pembelajaran yang diajarkan di kelas disesuaikan dengan kemampuan dan pengalaman siswa. Dalam proses pembelajaran, media pengajaran merupakan wahana penyampaian informasi atau pesan pembelajaran yang sangat penting bagi siswa. Pembelajaran melalui penggunaan media, perlahan-lahan mampu menggeser sistem pembelajaran tradisional yang hanya menggunakan buku-buku teks (Dimyati, 2005). Guru tidak lagi sebagai satu-satunya sumber belajar bagi siswa. Dengan adanya media, siswa dapat belajar dimana saja, kapan saja dan dengan apa saja. Fungsi media dalam pembelajaran dapat ditunjukkan pada gambar berikut ini:

11 |Teknologi, ifformasi, dan Komunikasi 


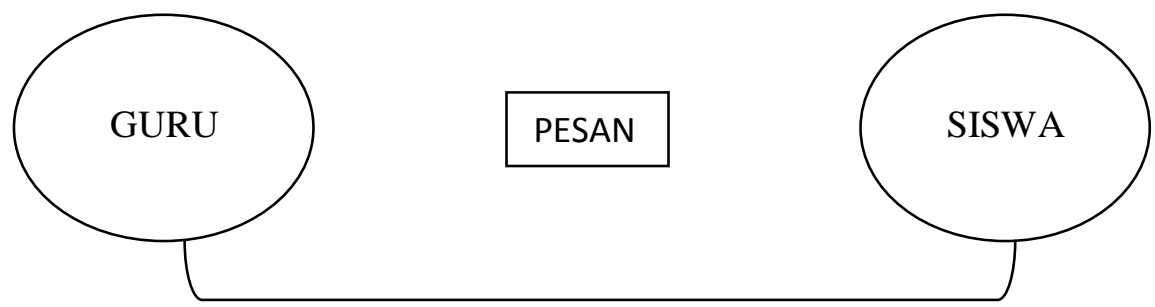

\section{Gambar 2. Fungsi media dalam proses pembelajaran}

Di lihat dari dasar filosofi, pembelajaran pada hakekatnya adalah proses komunikasi yang bertujuan untuk menyampaikan pesan/informasi sehingga dapat merangsang pikiran, perasaan dan minat serta perhatian peserta didik. Pembelajaran merupakan kegiatan yang membuat siswa belajar dengan melibatkan beberapa unsur intrinsic maupun ekstrinsik (berkaitan dalam diri siswa atau guru, termasuk lingkungan) guna tercapainya tujuan belajar mengajar yang telah ditentukan. Dengan adanya media pada proses belajar mengajar, diharapkan dapat membantu guru dalam meningkatkan prestasi belajar siswa. Oleh karena itu guru hendaknya menghadirkan media dalam setiap proses pembelajaran demi tercapainya tujuan pembelajaran. Posisi media pembelajaran sebagai komponen komunikasi ditunjukkan pada gambar sebagai berikut. 
Sumber Pengalaman

Pengalaman Penerima

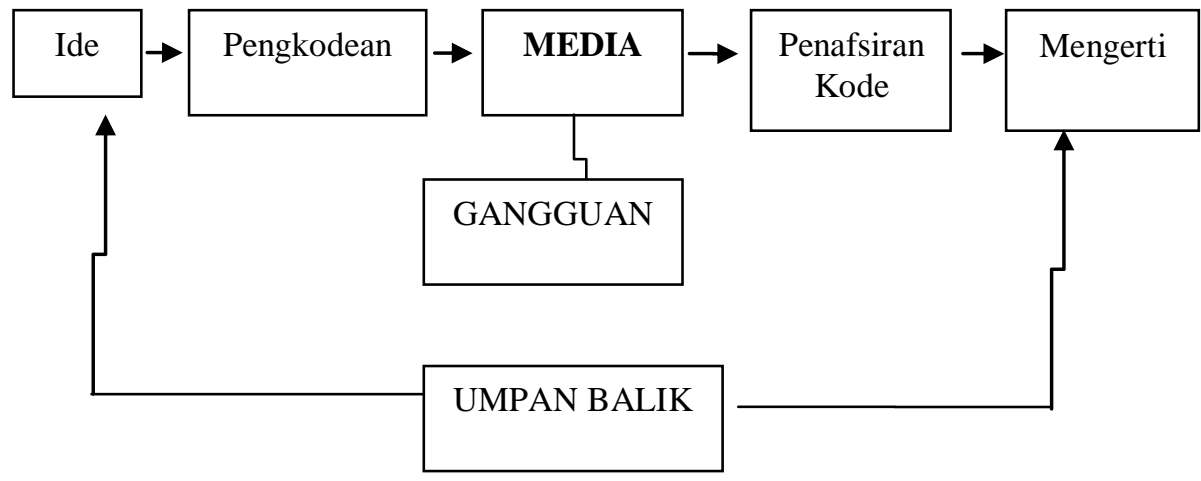

Gambar 3. Posisi media dalam pembelajaran

Kedudukan media sesuai yang digambarkan di atas berperan penting sebagai alat atau sarana teknis yang digunakan manusia untuk meningkatkan perbaikan/penyempurnaan lingkungannya. Kemajuan teknologi hakekatnya merupakan suatu pengetahuan manusia tentang cara menggunakan alat atau mesin untuk melaksanakan tugas pembelajaran secara efisien. Selain itu, dengan adanya teknologi dapat juga dikatakan sebagai pengetahuan, alat, dan sistem yang digunakan untuk membantu hidup lebih mudah dan lebih baik. Melalui pemanfaatan teknologi memungkinkan orang dapat berkomunikasi dengan lebih baik dan lebih cepat (Istiningsih: 2012).

13 | Teknologi, Informasi, dan Komunikasi 


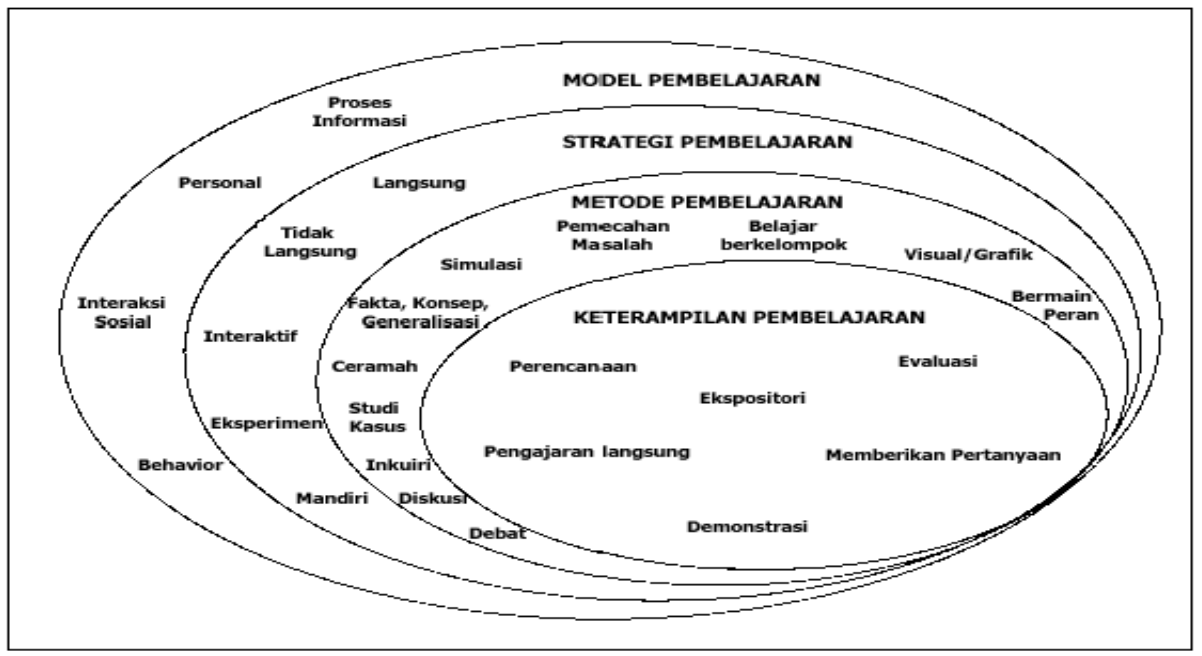

\section{Gambar 4. Kompleksitas proses pembelajaran}

Media pendidikan memiliki kegunaan mengatasi berbagai hambatan, antara lain: hambatan komunikasi, keterbatasan ruang kelas, sikap siswa yang pasif, pengamatan siswa yang kurang seragam, sifat obyek belajar yang kurang khusus sehingga tidak memungkinkan dipelajari tanpa media, tempat belajar yang terpencil dan lain sebagainya. Program pembelajaran yang menggunakan seperangkat media merupakan upaya efektif untuk meningkatkan daya tarik pembelajaran. Dengan memperhatikan kompleksitas proses belajar, maka ketepatan pemilihan media pembelajaran akan sangat berpengaruh terhadap hasil belajar siswa.

Istilah teknologi informasi dan komunikasi sudah sering digunakan dalam kehidupan sehari-hari termasuk dalam kegiatan pembelajaran. Namun sekalipun sudah sering digunakan, tampaknya masih terjadi pemahaman yang 14 | Teknologi, informasi, dan Komunikasi 
berbeda mengenai istilah TIK. Bahkan ada sebagian orang yang mengidentikkan TIK itu dengan komputer atau internet saja. Akibatnya setiap ada pembicaraan mengenai TIK, maka yang terlintas di dalam pemikiran yang bersangkutan adalah komputer dan internet. Di lingkungan pendidikan atau pembelajaran, sebagian guru pemahamannya masih terpusat pada komputer atau internet. Pemahaman yang demikian mengakibatkan bervariasinya sikap guru dalam memahami pemanfaatan TIK untuk pembelajaran.

Pemahaman lain mengenai teknologi dalam konteks pembelajaran di kelas adalah sebagai alat atau sarana yang digunakan untuk melakukan perbaikan/penyempurnaan kegiatan pembelajaran sehingga para siswa menjadi lebih otonom dan kritis dalam menghadapi masalah, yang pada akhirnya bermuara pada peningkatan hasil kegiatan belajar siswa. Teknologi dapat dan benar-benar membantu siswa dalam mengembangkan semua jenis ketrampilan, mulai dari tingkat yang sangat dasar sampai dengan tingkat ketrampilan berpikir yang lebih tinggi. (Istiningsih: 2012). Dengan demikian dapat dipahami bahwa penggunaan media pembelajaran berbasis ICT dapat meningkatkan kemampuan representasi siswa. Dalam teori representasi dijelaskan bahwa dengan menggunakan media pembelajaran berbasis teknologi, akan mempermudah proses pembelajaran sehingga meningkatkan kualitas pembelajaran dan dapat meningkatkan kemampuan representasi siswa. Semua teknologi berhubungan dengan pengambilan, pengumpulan (akuisisi), pengolahan, penyimpanan, penyebaran, dan penyajian informasi.

15 | Teknologi, Informasi, dan Komunikasi 
Pemahaman TIK yang demikian ini mencakup semua perangkat keras, perangkat lunak, kandungan isi (materi pelajaran) dan infrastruktur yang fungsinya berkaitan dengan dengan pengambilan, pengumpulan (akuisisi), pengolahan, penyimpanan, penyebaran, dan penyajian informasi (materi pelajaran). Sampai sejauh ini perkembangan teknologi pendidikan tidak hanya terbatas pada perkembangan yang terkini yaitu komputer dan internet. Artinya definisi teknologi pendidikan sebagai konsep multidimensional yang meliputi: 1) suatu proses sistematis yang melibatkan penerapan pengetahuan dalam upaya mencari solusi yang dapat digunakan dalam memecahkan masalah-masalah belajar dan pembelajaran; 2) produk seperti buku teks, program audio, program televisi, software komputer dan lain-lain; 3) suatu profesi yang terdiri dari berbagai kategori pekerjaan; dan 4) merupakan bagian spesifik dari pendidikan.

\section{Table 1. Perkembangan konsep komunikasi interaktif}

\begin{tabular}{|l|l|l|}
\hline \multicolumn{1}{|c|}{ Alat } & \multicolumn{1}{c|}{ Offline } & \multicolumn{1}{c|}{ Online } \\
\hline Teks & $\begin{array}{l}\text { Buku, majalah, surat } \\
\text { kabar, jurnal }\end{array}$ & $\begin{array}{l}\text { E-book, e- } \\
\text { magazine,e-news, } \\
\text { e-journal }\end{array}$ \\
\hline Suara gambar, & Tape player/recorder & Radio, telephone \\
\hline $\begin{array}{l}\text { Photo, proyektor } \\
\text { teks }\end{array}$ & Flash, fikr \\
\hline Film, suara, teks & $\begin{array}{l}\text { Film proyektor, video } \\
\text { player/recorder }\end{array}$ & Televisi \\
\hline Multimedia & Komputer & Internet \\
\hline
\end{tabular}

Perkembangan kearah komunikasi interaktif memiliki dampak terhadap perkembangan konsep teknologi pendidikan 16 | Teknologi, Informasi, dan Komunikasi 
yang banyak memperhatikan perubahan posisi decoder dan encoder dalam menerima, mengolah, dan menyampaikan feed back pesan sehingga terjadinya saling memberi informasi. Program pembelajaran pada hakekatnya ditujukan untuk kepentingan efesiensi pembelajaran, sehingga setiap penyelenggaraan pembelajaran perlu didasarkan atas prinsipprinsip pengajaran yang tepat. Dalam kaitan ini, keberhasilan untuk memecahkan masalah pembelajaran adalah sepenuhnya ditentukan oleh guru yang melaksanakan pemanfataan TIK itu sendiri. Para peneliti telah menyadari bahwa TIK tidak dapat diberlakukan sebagai variabel bebas tunggal dan prestasi belajar siswa tidak semata-mata hanya ditentukan oleh sebaik apapun siswa mencapai hasil tes standar tetapi juga ditentukan oleh kemampuan siswa untuk menggunakan ketrampilan berpikir tingkat tinggi (seperti: berpikir kritis, berpikir analitis, membuat inferensi dan pemecahan masalah)

\section{B. Landasan media pembelajaran}

Ada beberapa tinjauan tentang landasan penggunaan media pembelajaran, antara lain landasan filosofis, landasan psikologis dan landasan empiris.

\section{Landasan filosofis}

Perkembangan teknologi pendidikan tidak dapat dilepaskan dengan perkembangan teknologi pada umumnya. Berbagai perangkat pendidikan dan sarana pendidikan yang modern turut mendukung optimalisasi pembelajaran, baik di tingkat sekolah maupun dalam kehidupan kita sehari-hari. Perkembangan teknologi khususnya teknologi informasi dan komunikasi banyak menawarkan berbagai kemudahan-kemudahan dalam

17 | Teknologi, Informasi, dan Komunikasi 
menunjang proses belajar mengajar. Agar proses belajar mengajar dapat berhasil dengan baik, peserta didik sebaiknya diajak memanfaatkan semua alat inderanya. Guru sebaiknya berupaya menampilkan rangsangan (stimulus) yang dapat diproses dengan berbagai alat indera. Semakin banyak alat indera yang digunakan untuk menerima dan mengolah informasi, semakin besar pula kemungkinan informasi tersebut dapat dimengerti dan dapat dipertahankan dalam ingatan. Sebagaimana dalam firman Allah Q.S Al-Baqarah (30)

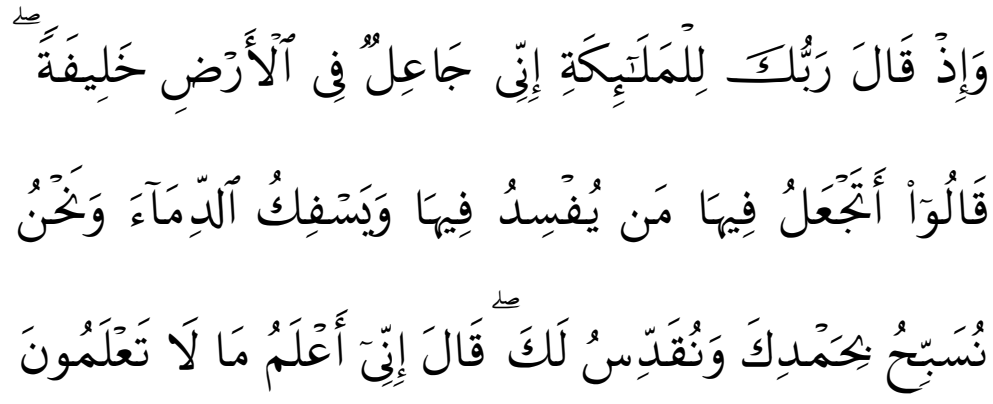

"Ingatlah ketika Tuhanmu berfirman kepada Para Malaikat: "Sesungguhnya aku hendak menjadikan seorang khalifah di muka bumi." mereka berkata: "Mengapa Engkau hendak menjadikan (khalifah) di bumi itu orang yang akan membuat kerusakan padanya dan menumpahkan darah, Padahal Kami Senantiasa bertasbih dengan memuji Engkau dan mensucikan Engkau?" Tuhan berfirman: "Sesungguhnya aku mengetahui apa yang tidak kamu ketahui."

18 | Teknologi, Informasi, dan Komuníkasi 
Dengan melihat berbagai macam objek ilmu atau fenomena, Allah memberikan berbagai macam tata cara dan sarana yang harus digunakan untuk meraih pengetahuan. Sarana yang dimiliki seorang manusia dimaksudkan berupa pendengaran, penglihatan, akal, serta hati. Dengan keempat sarana ini manusia bisa melakukan eksperimen, pengamatan, trial and error, diskusi dan berbagai cara-cara yang lain dengan memaksimalkan keempat sarana tersebut

Secara garis besarnya proses komunikasi menurut onong (1994) terbagi menjadi dua tahap, yakni secara primer dan secara sekunder: pertama, proses komunikasi secara primer adalah proses penyampaian pikiran dan atau perasaan seseorang kepada orang lain dengan menggunakan lambang atau symbol sebagai media. Lambang sebagai media primer dalam proses komunikasi adalah bahasa, isyarat, gambar, warna, dan lain sebagainya yang secara langsung mampu "menerjemahkan" pikiran dan atau perasaan komunikator kepada komunikan. Kedua, proses komunikasi secara sekunder adalah proses penyampaian pesan oleh seseorang kepada orang lain sengan menggunakan sarana atau alat yang sering digunakan dalam komunikasi.

Menurut Mayer (2009) dalam teori kognitif multimedia learning, bahwa peserta didik-peserta didik yang belajar dengan kata-kata dan gambar-gambar bisa menghasilkan $89 \%$ lebih banyak solusi kreatif dalam tes transfer dibandingkan peserta didik-peserta didik yang belajar dengan kata-kata saja. Saat kata-kata disajikan sebagai narasi, saluran auditori bisa digunakan untuk 
pemrosesan kata-kata. Pada saat yang sama, saluran visual bisa digunakan untuk pemrosesan gambar-gambar. Dengan cara ini, bebannya jadi berimbang diantara dua saluran sehingga tidak ada satu saluran yang kelebihan beban. Gambar-gambar masuk melalui mata (diproses disaluran pictorial) dan kata-kata terucapkan masuk lewat telinga (diproses disaluran verbal). Otak manusia memiliki tempat khusus untuk sejumlah pembelajaran yang disebut ingatan jangka panjang. Dari ungkapan tersebut dapat disimpulkan bahwa daya tarik dalam belajar mampu meningkatkan minat belajar dan memperpanjang ingatan terhadap pelajaran. Hal ini disebabkan visualisasi mencoba menggambarkan hakekat pesan dalam bentuk yang menyerupai keadaan yang sebenarnya. Pesan visual sangat efektif dalam memperjelas informasi. Melalui penggunaan media pengajaran diharapkan dapat mempertinggi kualitas belajar mengajar yang pada akhirnya dapat mempengaruhi kualitas hasil belajar siswa.

\section{Landasan psikologis}

Dengan memperhatikan kompleks dan uniknya proses belajar, maka ketepatan pemilihan media dan metode pembelajaran sangat berpengaruh terhadap hasil belajar siswa. Oleh sebab itu dalam pemilihan media, perlu memperhatikan kompleksitas dan keunikan proses belajar, memahami makna persepsi serta faktor yang berpengaruh diupayakan secara optimal agar proses pembelajaran dapat berlangsung efektif. 
Proses belajar mengajar di sekolah seringkali dihadapkan pada materi yang abstrak dan diluar pengalaman siswa sehari-hari, sehingga materi menjadi berat dan sulit diajarkan oleh guru dan sulit untuk dipahami oleh siswa. Dalam hal ini peran guru sebagai pengembang ilmu sangat besar untuk menentukan dan memilih serta melaksanakan pembelajaran yang tepat dan efisien bagi peserta didik bukan hanya berupa pembelajaran yang bersifat konvensional. Pembelajaran yang baik dapat ditunjang dari suasana pembelajaran yang kondusif serta hubungan komunikasi antara guru, siswa dapat berjalan dengan baik.

Jerome Burner (dalam Daryanto: 2010), mengemukakan bahwa dalam proses pembelajaran hendaknya menggunakan urutan dari belajar dengan gambaran atau film (iconic representation of experiment) kemudian ke belajar dengan simbol, yaitu menggunakan kata-kata (symbolic representation) dimulai dari siswa berpartisipasi dalam pengalaman nyata, kemudian menuju siswa sebagai pengamat kejadian nyata, dilanjutkan ke siswa sebagai pengamat terhadap kejadian yang disajikan dengan media, dan terakhir siswa sebagai pengamat kejadian yang disajikan dengan simbol. 


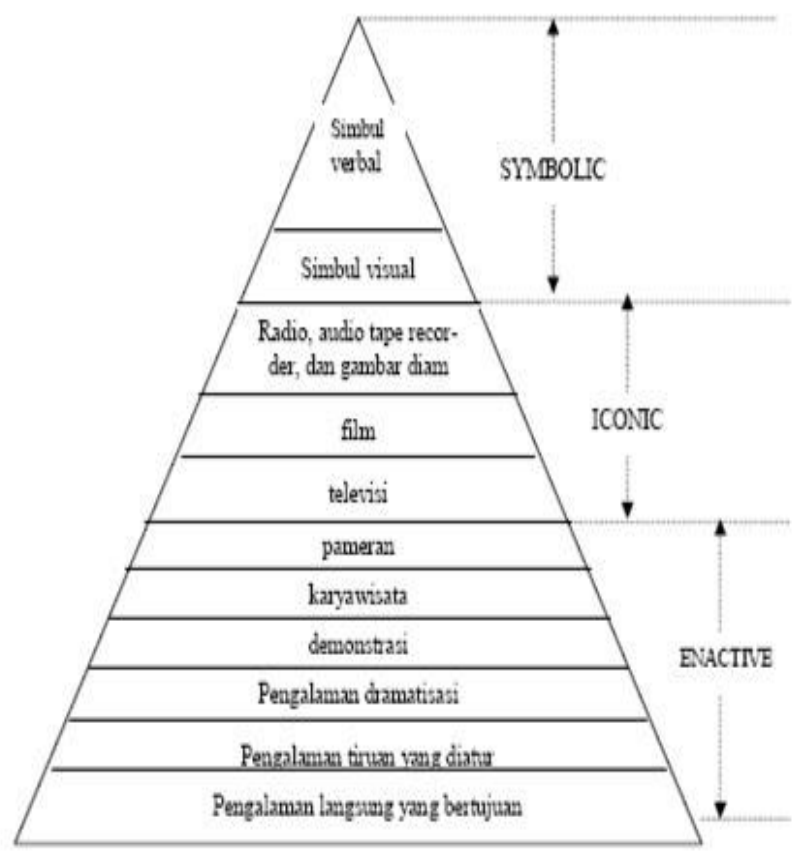

\section{Gambar 5. Kerucut pengalaman Dale}

Dalam menentukan jenjang konkrit ke abstrak Edgar Dale dengan Bruner pada gambar di atas memiliki faktor persamaan dan perbedaan diantara keduanya. Dale lebih menekankan siswa berperan aktif sebagai pengamat realitas/kejadian/peristiwa pada stimulus yang diamati, sedang Bruner menekankan pada proses mental siswa pada saat mengamati obyek.

\section{Landasan empiris}

Dalam Islam, baik pria maupun wanita mempunyaikesempatan yang sama untuk belajar. Dalam 22 | Teknologi, Informasi, dan Komuníkasi 
belajar tidak mengenal waktu, dan juga tidak mengenal gender. Sehingga setiap orang, baik pria maupun wanita bisa mengembangkan potensi yang diberikan oleh Allah Swt kepada kita sehingga potensi itu berkembang dan sampai kepada kesempurnaan yang diharapkan. Karena itulah, agama menganggap bahwa belajar itu termasuk bagian dari ibadah. Ibadah tidak terbatas kepada masalah shalat, puasa, haji, dan zakat. Bahkan belajar itu dianggap sebagai ibadah yang utama, karena dengan ilmulah kita bisa melaksanakan ibadah-ibadah yang lainnya dengan benar.

Seorang siswa yang telah melalui proses belajar, idealnya ditandai oleh munculnya pengalamanpengalaman psikologis dan baru yang positif. Pengalaman-pengalaman yang bersifat kejiwaan tersebut diharapkan dapat mengembangkan aneka ragam sifat, sikap, dan kecakapan yang konstruktif, bukan kecakapan yang destruktif. Dalam proses belajar mengajar, kehadiran alat/media mempunyai arti yang cukup penting. Karena dalam kegiatan tersebut, ketidakjelasan bahan yang disampaikan dapat dibantu dengan menghadirkan media sebagai perantara. Namun, meskipun begitu pentingnya alat/media bagi tercapainya tujuan pendidikan, masih banyak dijumpai lembagalembaga pendidikan yang kurang mementingkan suatu alat/media tersebut. Terbukti banyak ditemukan kasus pendidik yang tidak mempergunakan media sesuai dengan bahan yang diajarkan, sehingga dalam pembelajaran pendidikan agama Islam, peserta didik 
mengalami banyak kesulitan dalam menyerap dan memahami pelajaran yang disampaikan.

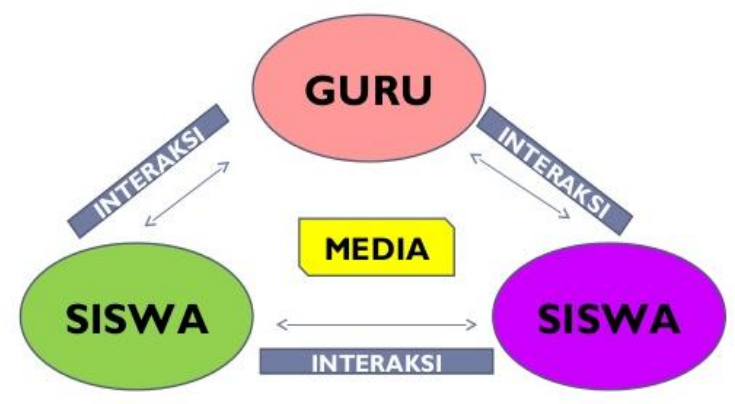

\section{Gambar 6. Interaksi penggunaan media pembelajaran}

Berdasarkan temuan penelitian menunjukkan bahwa terdapat interaksi antara penggunaan media pembelajaran dan karakteristik belajar siswa dalam menentukan hasil belajar siswa. Artinya siswa mendapat keuntungan yang signifikan bila ia belajar dengan menggunakan media yang sesuai dengan karakteristiknya. Temuan-temuan penelitian lainnya juga menunjukkan bahwa terdapat dampak positif antara penggunaan media pembelajaran dengan karakteristik belajar siswa dalam menentukan hasil belajar siswa. Artinya siswa akan mendapat keuntungan yang signifikan bila mereka belajar menggunakan media pembelajaran yang sesuai dengan karakteristik belajar mereka. Kisah Nabi Sulaiman yang memperkenalkan kemegahan istananya dengan berbagai kecanggihan pada saat itu, hal ini merupakan salah satu daya tarik dalam teknik komunikasi agar dapat berjalan dengan baik. Dalam melaksanakan tugasnya sebagai pendidik, guru 24 |Teknologi, informasi, dan Komunikasi 
perlu dilandasi langkah-langkah dengan sumber ajaran agama, sesuai firman Allah SWT dalam Surah An-Nahl ayat 44, yaitu:

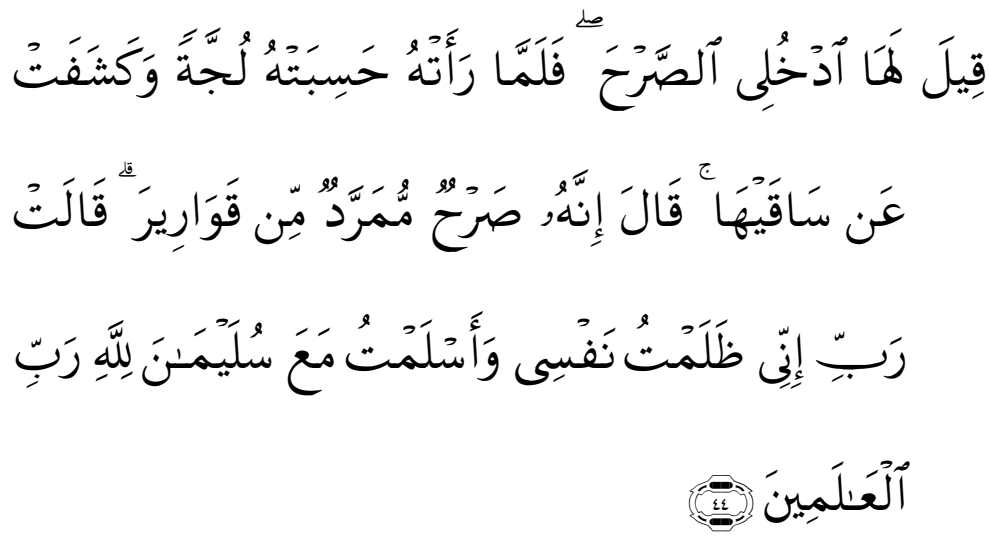

Dikatakan kepadanya: "Masuklah ke dalam istana". Maka tatkala Dia melihat lantai istana itu, dikiranya kolam air yang besar, dan disingkapkannya kedua betisnya. berkatalah Sulaiman: "Sesungguhnya ia adalah istana licin terbuat dari kaca". berkatalah Balqis: "Ya Tuhanku, Sesungguhnya aku telah berbuat zalim terhadap diriku dan aku berserah diri bersama Sulaiman kepada Allah, Tuhan semesta alam".

Hubungan ayat diatas dengan proses pembelajaran yang juga merupakan salah satu bentuk komunikasi berada di wilayah kajian pendidikan. Penggunaan media burung Hud-Hud oleh Nabi Sulaiman dalam menyampaikan surat kepada Ratu Balqis merupakan implementasi teknologi pada masa itu, sebab dengan penggunaan burung tersebut dapat membuat proses komunikasi lebih efektif dan efisien. Bahkan dalam pertemuan keduanya difasilitasi dengan sarana dan 25 | Teknologi, informasi, dan Komunikasi 
prasarana yang menggunakan teknologi canggih, sehingga dapat membuat suasana nyaman dan kondusif. Dengan demikian, dalam pembelajaran seharusnya dapat menggunakan media yang dapat memperlancar komunikasi dalam prosesnya, dan menggunakan sarana yang dapat membuat peserta didik nyaman, sehingga pembelajaran dapat mencapai tujuan secara maksimal.

Dalam masalah penerapan media pembelajaran, pendidik harus memperhatikan perkembangan jiwa keagamaan anak didik, karena faktor inilah yang justru menjadi sasaran media pembelajaran. Tanpa memperhatikan serta memahami perkembangan jiwa anak atau tingkat daya pikir anak didik, guru akan sulit diharapkan untuk dapat mencapai sukses. Hal ini sejalan dengan hasil penelitian Jamaluddin Alhuda yang menunjukkan terdapat interaksi antara penggunaan media pembelajaran dan karakteristik belajar siswa dalam menentukan hasil belajar siswa. Artinya, siswa mendapat keuntungan yang signifikan dengan menggunakan media yang sesuai dengan karakteristik gaya belajarnya.

Hasil penelitian Umi Faizah menunjukkan bahwa penggunaan media cerita bergambar sangat efektif dalam meningkatkan ketrampilan menyimak dan ketrampilan membaca siswa. Hal ini memberikan petunjuk bahwa penggunaan cerita bergambar lebih tepat diterapkan daripada pembelajaran yang hanya mengandalkan bukubuku paket sebagai satu-satunya sumber belajar, karena kisah memainkan peranan penting dalam menarik perhatian anak dan membangun pola pikirnya. Kisah menempati peringkat pertama sebagai landasan dasar 26 |Teknologi, Informasi, dan Komunikasi 
yang memberikan dampak positif pada akal dan pikiran anak.

Berdasarkan landasan empiris tersebut, maka pemilihan media pembelajaran hendaknya tidak berdasar kesukaan dan kemudahan guru dalam membuat dan merencanakan, tetapi harus mempertimbangkan kesesuaian antara karakteristik pebelajar, karakteristik materi pelajaran, dan karakteristik media pembelajaran itu sendiri.

\section{Karakteristik Media Pembelajaran}

Karakteristik media pembelajaran yang dibutuhkan oleh warga belajar sebenarnya mengacu pada kondisi atau karakteristik mereka yang memerlukan penyajian materi yang berbeda dengan orang dewasa lainnya. Peserta didik usia sekolah dasar berada pada tahap pra operasional konkret, pada tahap ini anak didik masih memerlukan pemahaman secara konkret. Melihat buku-buku tekstual yang tebal sekali halamannya, motivasi belajar mereka menurun, apalagi jika di dalamnya tidak disertakan gambar-gambar yang menarik. Jika demikian maka jangan harap rancangan pembelajaran bisa berjalan dengan baik. Dengan demikian media pembelajaran yang dibutuhkan warga belajar meliputi kriteria-kriteria berikut ini:

1. Mudah dipahami, maka perlu mempertimbangkan judul, isi, ringkasan, outline, penempatan dan pengunaan kotak, heading, pertanyaan, urutan, mengurutkan daftar, nomor dalam teks, pemberian isyarat dan lain sebagainya. Selain

27 | Teknologi, Informasi, dan Komunikasi 
mudah dipahami untuk memahami pesan yang disampaikan, terdapat beberapa cara yang dierapkan seperti: 1) memberikan garis bawah, 2) menempatkan sesuatu secara bersamaan (mempertimbangkan jarak kedekatan), 3) mengikuti bentuk umum (konsisten menerapkan bentuk/perlakuan) seperti kombinasi warna berdasarkan roda warna tradisional, dan 4) menggunakan kombinasi warna yang harmonis dan gambar kontras dengan backgroundnya.

2. Mudah untuk dibaca (ensure legability). Prinsip mudah dibaca perlu dipastikan yaitu tulisan jelas, bisa terbaca, dan gambar jelas terlihat, dan menghilangkan gangguan dalam transfer pesan. Terkait dengan hal tersebut, beberapa langkah yang dapat diterapkan dalam media pembelajaran, yakni: 1) media pembelajaran menggunakan petunjuk-petunjuk yang jelas, dan 2) menggunakan contoh-contoh yang mudah dipahami oleh warga belajar.

3. Mendesain media yang menarik, memasukkan sesuatu yang baru, texture interaktif, memilih style yang paling baik dan menggunakan warna yang menarik agar pembaca memberikan perhatian dan memikirkan pesan yang disampaikan dalam media pembelajaran. Untuk mendongkrak keterlibatan aktif warga belajar terhadap media pemelajaran yang disajikan dapat dilakukan antara lain: 1) pattern, meliputi keputusan tentative (berubahubah) salah satunya yang dianjurkan adalah "overall look" yaitu bagaimana pandangan mata pembaca kepada tampilan. Faktor utama yang berpengaruh pada overall look, yaitu: align (bentuk lurus dan penyatuan), bentuk,

28 | Teknologi, Informasi, dan Komunikasi 
keseimbangan, style, skema warna dan warna yang menarik, 2) alignment dimaksudkan dengan menempatkan elemen utama pada sebuah tampilan sehingga jelas hubungan bagian satu dengan yang lainnya, 3) shape berkenaan dengan pengaturan gambar dan verbal (teks), dan 4) balance atau bentuk keseimbangan. Dalam memilih warna patut dipertimbangkan untuk menumbuhkan respon emosi pembaca yaitu sebuah warna yang aktif, dinamis dan menumbuhkan rasa kehangatan dan kesejukan. Kecenderungan terhadap warna yang sejuk dan hangat dipengaruhi oleh usia bahkan bisa juga karena budaya pembaca. (Hafiz, 2008).

\section{Media Pembelajaran Dua Dimensi}

Media pembelajaran dua dimensi adalah sebutan umum untuk alat peraga pembelajaran yang hanya memiliki ukuran panjang dan lebar pada satu titik bidang datar. Media pembelajaran dua dimensi meliputi media grafis, media bentuk papan dan media cetak yang penampilan isinya tergolong dua dimensi (Daryanto, 2010).

\section{Media grafis}

Media grafis adalah suatu penyajian secara visual yang menggunakan titik-titik, garis-garis, gambargambar, tulisan-tulisan atau simbol visual yang lain dengan maksud untuk mengihtisarkan, menggambarkan dan merangkum suatu ide, data atau kejadian. Fungsi umum media grafis adalah untuk menyalurkan pesan dari sumber ke penerima pesan. Sedangkan fungsi khususnya adalah untuk menarik perhatian, memperjelas ide, 
mengilustrasikan atau menghiasi fakta yang mungkin akan cepat dilupakan atau diabaikan bila tidak digrafiskan.

Karakteristik media grafis dapat dilihat berdasarkan ciri-cirinya, kelebihan yang dimilikinya, kelemahannya, unsur-unsur desain dan kriteria pembuatannya, dan jenisjenisnya. Macam-macam media grafis diantaranya; 1) diagram yakni suatu gambaran sederhana untuk memperlihatkan hubungan timbal balik dalam proses pembelajaran mengenai fakta-fakta dan gagasan yang akan diuraikan; 2) grafik merupakan suatu grafis yang menggunakan titik-titik atau garis untuk menyampaikan informasi statistik yang saling berhubungan; 3) poster merupakan kombinasi visualisasi yang kuat dengan warna dan pesan dengan maksud untuk menangkap perhatian orang agar menanamkan gagasan yang berarti di dalam ingatannya; 4) kartun menggambarkan dalam bentuk lukisan atau karikatur tentang orang, gagasan atau situasi yang didesain untuk mempengaruhi opini masyarakat; dan 5) komik merupakan suatu bentuk kartun yang mengungkapkan karakter dan memerankan suatu berita dalam urutan yang erat dihubungkan dengan gambar dan di rancang untuk memberikan hiburan pada pembaca. 

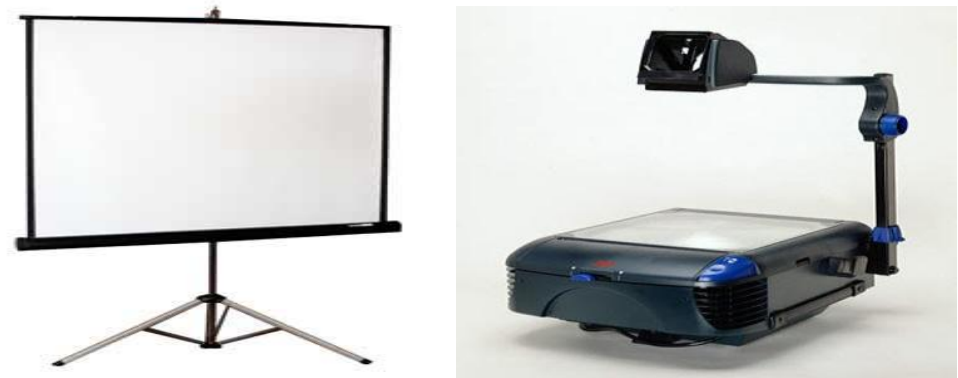

\section{Gambar 7. Bentuk layar atau screen OHP}

\section{Media Papan}

Media bentuk papan terdiri dari papan tulis, papan flannel, papan tempel dan papan magnet. Keuntungan menggunakan papan tulis adalah dapat digunakan disegala jenis tingkatan lembaga, mudah mengawasi keaktifan kelas, ekonomis dapat dibalik. Kekurangannya adalah memungkinkan sukarnya mengawasi aktivitas peserta didik, berdebu, kurang menguntungkan bagi guru yang tulisannya kurang bagus.

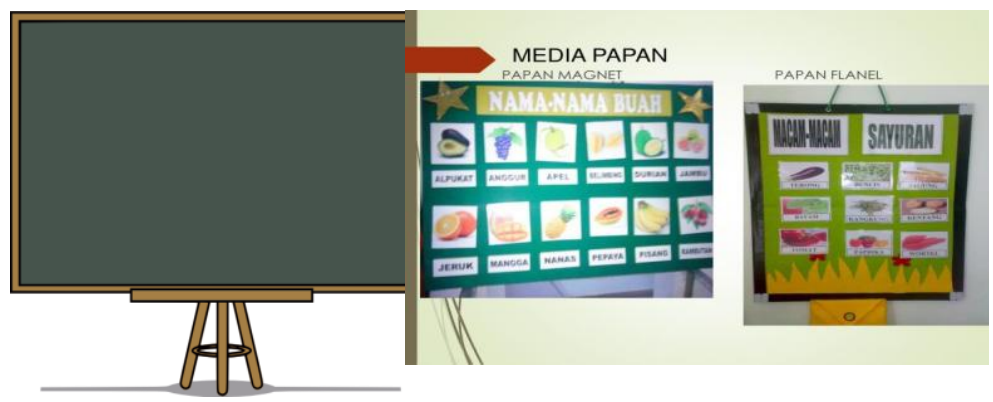

Gambar 8. Berbagai bentuk media papan

31 |Teknologi, Informasi, dan Komunikasi 


\section{Media Cetak}

Secara historis, istilah media cetak muncul setelah ditemukannya alat pencetak oleh Johan Gutenberg tahun 1456. Kcmudian dalam bidang percetakan berkembanglah produk alat pencetak yang semakin modern dan efektif dalam penggunaannya. Buku pelajaran sering disebut buku teks adalah suatu penyajian dalam bentuk bahan cetakan secara logis dan sistematis tentang suatu cabang ilmu pengetahuan atau bidang studi tertentu. Manfaat buku pelajaran antara lain: 1) sebagai alat pelajaran individual, 2) sebagai pedoman guru dalam mengajar, 3) sebagai alat untuk mendorong peserta didik memilih teknik belajar yang sesuai, dan 4) sebagai alat untuk meningkatkan kecakapan guru dalam mengorganisasi bahan pelajaran. Keuntungan penggunaan buku pelajaran adalah ekonomis, komprehensif dan sistematis, mengembangkan sikap mandiri siswa dalam belajar.

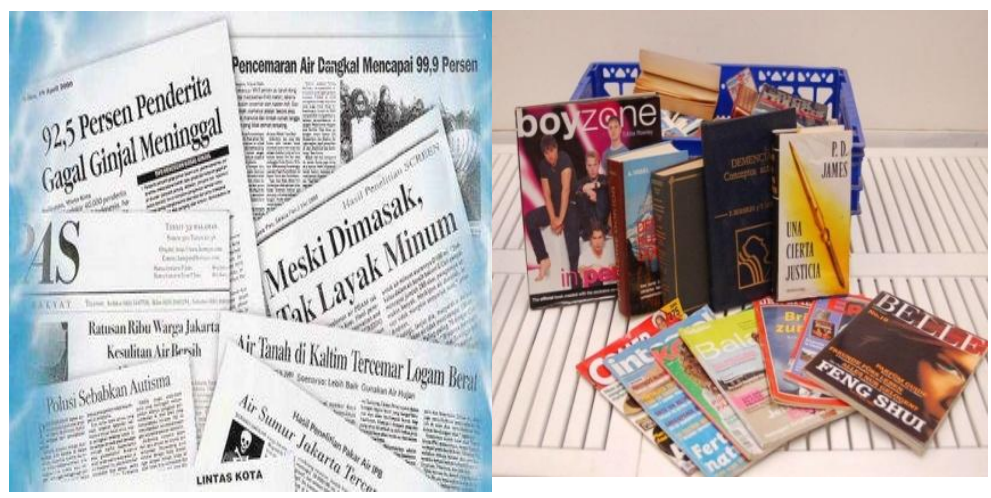

Gambar 9. Berbagai bentuk media cetak

32 | Teknologi, informasi, dan Komunikasi 


\section{E. ICT dalam Pembelajaran Inovatif}

TIK (Teknologi, Informasi dan Komunikasi) atau dalam bahasa Inggris ICT (Information and communication technology) saat ini sangat mempengaruhi kehidupan manusia dalam berbagai aspek. Semakin tinggi kemampuan dalam memanfaatkan TIK, akan semakin tinggi pula kemampuan bersaing dalam kehidupan. Teknologi komunikasi yang terus mengalami kemajuan akan mempengaruhi pola komunikasi masyarakat nantinya. Menurut Tandeur, et.al., (2006) : "Information and Communication Technology (ICT) plays an important role in society when we take into account the social, cultural and economic role of komputers and the Internet." Oleh karena itu, dapat dikatakan bahwa mengintegerasikan TIK dalam kehidupan khususnya dalam aspek pendidikan merupakan hal yang sangat penting saat ini.
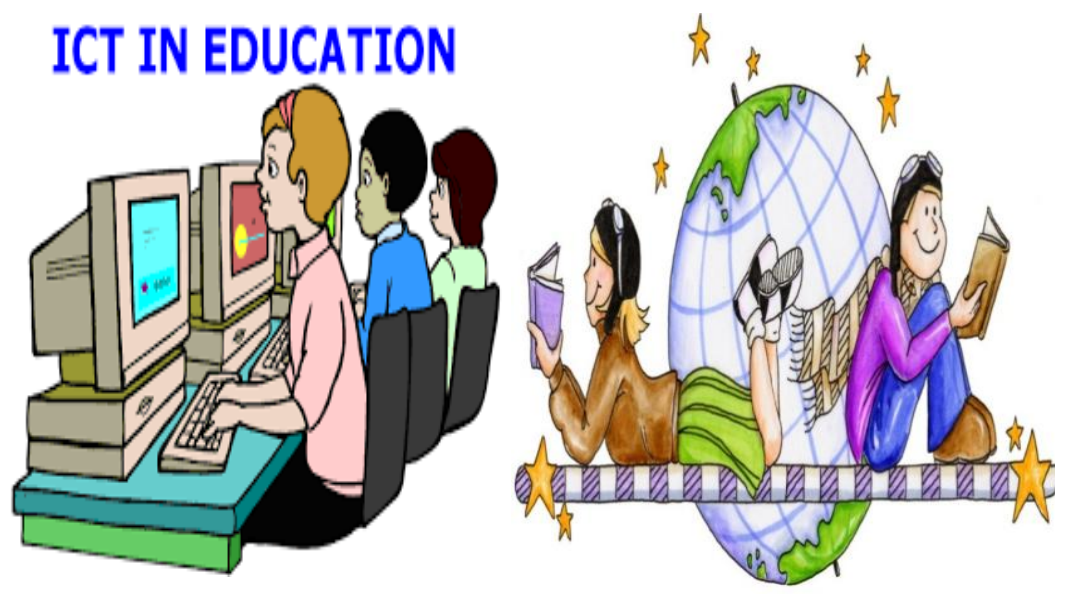

Gambar 10. Perkembangan teknologi, informasi, dan komunikasi

33 | Teknologi, Informasi, dan Komunikasi 
Pada dasawarsa terakhir ini, perkembangan ICT baik dilihat dari segi hardware maupun software sangatlah cepat. Umumnya, perkembangan perangkat ICT tersebut mengarah ke bentuk yang semakin kecil, harga yang semakin murah, kekuatan yang semakin powerfull, serta semakin terintegrasi dengan kehidupan sehari-hari. Kekayaan informasi yang sekarang tersedia di internet telah lebih mencapai harapan dan bahkan imajinasi para penemu sistemnya. Melalui internet dapat diakses sumber-sumber informasi tanpa batas dan aktual dengan sangat cepat. Adanya internet memungkinkan seseorang di Indonesia untuk mengakses perpustakaan di Amerika Serikat dalam bentuk Digital Library.

Saat ini hampir semua siswa tiap hari mengakses internet. Menurut Hardjito yang dikutip Waryanto (2012) menyatakan bahwa secara nyata internet memang akan bisa digunakan dalam setting pembelajaran di sekolah, karena memiliki karakteristik yang khas, yaitu: 1) sebagai media interpersonal dan juga sebagai media massa yang memungkinkan terjadinya komunikasi one-to-one maupun one-to-many, 2) memiliki sifat interaktif, dan 3) memungkinkan terjadinya komunikasi secara syncronous maupun asyncronous, sehingga memungkinkan terselenggarakannya ketiga jenis komunikasi yang merupakan syarat terselenggaranya suatu proses belajar mengajar.

Dalam pembelajaran abad-21 ini, guru dituntut untuk mampu menggunakan TIK sebagai sumber belajar, salah satunya dengan menggunakan akses internet. Internet merupakan sumber informasi yang tak terbatas (Slamet, 2009). Selain mampu menggunakan TIK sebagai sumber belajar, guru juga dituntut untuk mampu menciptakan 34 |Teknologi, informasi, dan Komuníkasi 
pembelajaran kreatif dan inovatif yang terintegrasi dengan TIK. Menurut Suhendar yang dikutip oleh Aloysius (2009), pembelajaran yang kreatif dan menyenangkan merupakan hal yang sangat penting, karena dapat membantu siswa untuk berhasil dalam pembelajaran, menciptakan solusi dalam memecahkan masalah, sangat mempengaruhi kehidupan siswa, menimbulkan rasa senang dan puas. Kemampuan guru dalam mengintegerasikan TIK ke dalam pembelajaran juga akan mempengaruhi kemampuan siswa secara signifikan dalam mencapai tujuan pendidikan.

Distance learning adalah suatu proses membawa informasi yang interaktif dan informasi pembelajaran yang ditujukan kepada siswa di suatu waktu, tempat dan tampilan (bentuk) yang tepat. Distance education adalah suatu situasi belajar antara tutor dan siswa yang dipisahkan oleh waktu atau tempat. Kontrol pembelajaran lebih besar berada pada siswa dari pada tutor, dan komunikasi antara tutor/guru dan siswa menggunakan media berteknologi komunikasi (Munir, 2008). Untuk pengembangan sistem jaringan TIK (ELearning), diperlukan perangkat keras penunjang terutama komputer sebagai peralatan kunci yang harus ada. Jumlah perangkat komputer dalam sebuah laboratorium pengendali tentunya akan dapat memudahkan pengaksesan seluruh materi pembelajaran yang telah dikembangkan. Selain itu, diperlukan jaringan komputer yang handal, seperti LAN, WAN, dan MAN. Adanya sistem koneksi yang bagus dengan jaringan internet sehingga bisa mengakses dunia global.

Sejak tahun 2000 UNESCO telah mendukung sekolah dasar dan menengah untuk menggunakan TIK, dengan menerbitkan berbagai buku mengenai TIK (John, 2012). Di 35 | Teknologi, Informasi, dan Komunikasi 
Indonesia, Permendiknas nomor 16 tahun 2007 telah mengatur standar kualifikasi akademik dan kompetensi guru. Salah satu Standar kompetensi guru Pendidikan Anak Usia Dini (PAUD) sampai dengan sekolah menengah pada kompetensi pedagogik adalah mampu memanfaatkan teknologi informasi dan komunikasi untuk kepentingan pembelajaran yang diampu dan pada kompetensi profesional yaitu mampu memanfaatkan teknologi informasi dan komunikasi untuk pengembangan diri (Kemendiknas, 2007).

Menurut Daniel (2012), teknologi, informasi, dan komunikasi, atau ICT adalah suatu kombinasi antara teknologi informatika dan teknologi komunikasi. TIK adalah alat untuk mendapatkan nilai tambah dalam menghasilkan suatu informasi yang cepat, lengkap, akurat, transfaran dan mutakhir. (Munir, 2009) TIK dapat diartikan sebagai segala sesuatu yang memudahkan manusia dalam menyalurkan informasi secara cepat dan efektif, baik berupa program maupun peralatan.

Beberapa jenis TIK yang paling sering diketahui oleh masyarakat umum adalah komputer (PC), laptop, printer, LCD projector, internet, intranet, dan lain-lain. Namun sebenarnya, televisi, radio, dan handphone juga termasuk ke dalam perangkat TIK. TIK terdiri dari hardware dan software. Hardware atau perangkat keras adalah segala sesuatu peralatan teknologi yang berupa fisik yang bisa disentuh. Software atau perangkat lunak adalah sistem yang dapat menjalankan atau yang berjalan dalam perangkat keras tersebut. Software dapat berupa operating sistem (OS), aplikasi, ataupun konten (Sudirman, 2009).

36 | Teknologi, Informasi, dan Komunikasi 


\section{F. Profesionalitas Guru dalam Pembelajaran}

Pengertian dasar kompetensi (competency) adalah kemampuan atau kecakapan. Padanan kata yang berasal dari kata bahasa Inggris itu cukup banyak dan yang lebih relevan dengan pembahasan ini adalah kata proficiency dan abilty yang memiliki arti kurang lebih sama yakni kemampuan. Hanya proficiency lebih sering digunakan orang untuk menyatakan kemampuan berperingkat tinggi. Kompetensi juga berarti: .... the state of being legally competent or qualified (Mcleod dalam Muhibbinsyah, 2010) yakni keadaan berwewenang atau memenuhi syarat menurut ketentuan hukum. Adapun kompetensi guru menurut Muhibbinsyah (2010), kompetensi guru merupakan kemampuan seorang guru dalam melaksanakan kewajiban-kewajibannya secara bertanggungjawab dan layak. Jadi kompetensi profesionalitas guru dapat diartikan sebagai kemampuan dan kewenangan guru dalam menjalankan profesi keguruannya. Artinya guru yang piawai dalam melaksanakan profesinya dapat disebut sebagai guru yang kompeten dan professional. Hal ini sebagaimana firman Allah Swt dalam Q.S Luqman ayat (13)

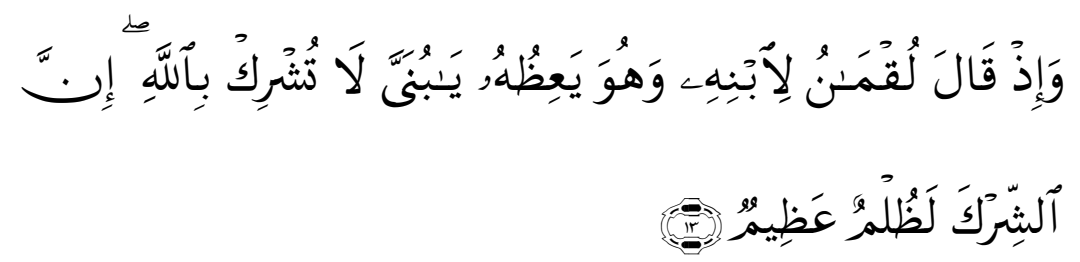

"dan (ingatlah) ketika Luqman berkata kepada anaknya, di waktu ia memberi pelajaran kepadanya: "Hai anakku, janganlah kamu mempersekutukan Allah, Sesungguhnya

37 | Teknologi, Informasi, dan Komunikasi 
mempersekutukan (Allah) adalah benar-benar kezaliman yang besar".

Ayat al-Qur'an diatas menjelaskan bahwa sifat-sifat yag harus dimiliki oleh orang tua sebagai guru pertama dan utama adalah mengajarkan ketuhanan yang pada akhirnya anak akan memiliki nilai hikmah atau kesadaran tentang kebenaran yang diperoleh melalui ilmu dan rasio. dapat bersukur kepada Allah, suka menasihati anaknya agar tidak mensekutukan Allah, memerintahkan anaknya agar melaksanakan salat, sabar dalam menghadapi penderitaan, dan lain sebagainya.

Kedudukan orang tua sangat penting dalam membina dan mendidik anak-anaknya, karena orang tua yang paling bertanggung jawab terhadap anak keturunannya. Dalam hal ini tugas dan peran seorang guru menentukan keberhasilan dalam mencapai peningkatan mutu pembelajaran. Kymet Selvi (2008) menyatakan bahwa dengan kompetensi guru yang bagus maka guru tersebut memiliki kemampuan yang baik pula dalam bidang pendidikan. Hal itui diungkapkan "teachers' competencies have been broadening with respect to reform studi es in education, development of teacher education, scientific results of educational science and other fields".

Kompetensi guru telah diperluas sehubungan dengan reformasi di bidang pendidikan, pengembangan pendidikan guru, hasil ilmiah ilmu pendidikan dan bidang lainnya. Guru merupakan penggerak utama penyelenggaraan pendidikan di suatu lembaga pendidikan. Kepemimpinan guru di jenjang pendidikan menengah sangat dibutuhkan para siswa karena guru harus mengajarkan ilmu pengetahuan. Di samping itu,

38 | Teknologi, informasi, dan Komunikasi 
guru juga mendidik siswanya dengan nilai-nilai untuk membentuk kepribadian karena pendidikan seharusnya berperan dalam pembentukan kepribadian manusia (Tilaar, 1999).

Dalam proses belajar mengajar, guru mempunyai tugas untuk mendorong, membimbing, dan memberi fasilitas belajar bagi siswa untuk mencapai tujuan. Teaching learning process is a planned interaction that promotes behavioral change that is not a result of maturation or coincidence (Teresa Banks, 2000). (Proses belajar mengajar adalah interaksi direncanakan mencapai perubahan perilaku yang bukan merupakan hasil dari pematangan atau kebetulan).

Kompetensi profesional guru dapat dilihat dari memberikan layanan profesional kepada peserta didik agar tujuan pembelajaran tercapai. Indikator professional guru dalam Permendiknas nomor 6 tahun 2007 meliputi: (1) mampu menyusun program pengajaran maupun praktik. (2) mampu menyajikan program pengajaran dan praktik. (3) mampu melaksanakan evaluasi proses dan hasil pembelajaran atau praktik. (4) mampu melaksanakan analisis hasil evaluasi belajar atau praktik. (5) mampu menyusun dan melaksanakan program perbaikan dan pengayaan. (6) mampu menyusun dan melaksanakan program bimbingan dan penyuluhan. (7) mampu membimbing siswa dalam kegiatan ekstra kurikuler atau dalam KTSP. (8) mampu melaksanakan bimbingan terhadap guru yang jabatan gurunya masih di bawahnya. (9) mampu membuat karya tulis atau karya ilmiah di bidang pendidikan. (10) mampu membuat alat pelajaran atau alat peraga. (11) mampu menciptakan karya seni. (12) mampu mengikuti kegiatan pengembangan kurikulum. (13) mampu 39 | Teknologi, Informasi, dan Komunikasi 
melaksanakan bimbingan karir siswa. (14) melaksanakan tugas tertentu di sekolah. (15) mampu melaksanakan kegiatan evaluasi pendidikan.

Kemampuan profesional guru merupakan salah satu bentuk layanan, bantuan dan pembinaan yang diberikan kepala sekolah kepada guru untuk mengembangkan dan memperbaiki proses belajar mengajar di kelas baik secara individu maupun kelompok. Tujuan kemampuan profesional guru adalah untuk memperoleh bagan tentang kegiatan pembelajaran dan kegiatan pengelolaan kelas yang dilakukan guru. Proses pembelajaran akan benar-benar menyenangkan jika guru mampu mengemasnya dengan teknologi pembelajaran. Teknologi memiliki peranan penting dalam menentukan kualitas kehidupan umat manusia mempengaruhi segala aspek kehidupan sekaligus memengaruhi kualitas budaya dari suatu bangsa. Guru di abad ini berhadapan dengan kenyataan, bahwa para siswa yang hadir disekolah telah memiliki kekayaan informasi yang mereka peroleh diluar sekolah seperti televisi dan internet.

40 | Teknologi, Informasi, dan Komunileasi 


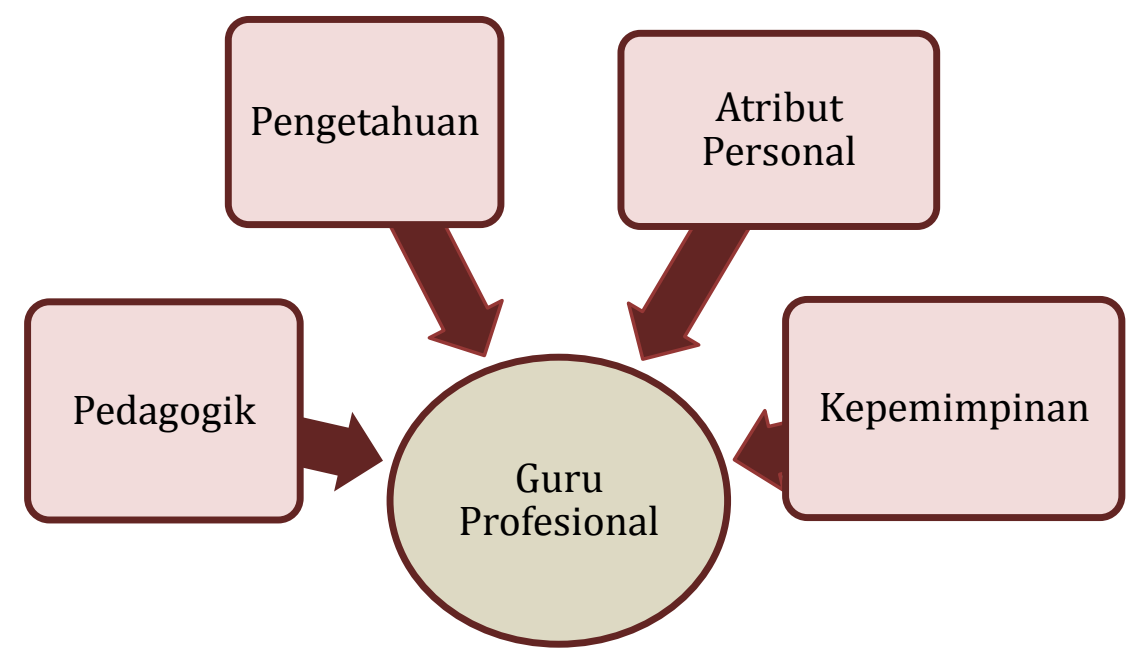

\section{Gambar 11. Komponen kompetensi guru}

Menurut Mulyasa (2011:106) guru dituntut untuk memiliki kompetensi dalam pemamfaatan teknologi terutama internet (e-learning). Karena penggunaan teknologi dalam pendidikan dimaksudkan untuk memudahkan kegiatan pembelajaran dan dapat diakses dengan mudah oleh peserta didik sehingga tujuan pembelajaran dapat tercapai. Untuk mencapai tujuan pembelajaran guru harus mampu menciptakan kondisi sedemikian rupa agar berbagai potensi dan kemampuan yang beragam itu dapat dikembangkan secara optimal. Salah satu wahana untuk mengembangkan kemampuan, potensi, minat dan bakat siswa melalui kegiatankegiatan ekstrakurikuler. Melalui kegiatan ekstra kurikuler minat, bakat dan kemampuan siswa akan merasa dihargai dan memiliki peluang untuk mengembangkan kemampuannya secara optimal tanpa dihambat oleh berbagai kegiatankegiatan akademik pembelajaran semata.

41 | Teknologi, informasi, dan Komunikasi 
Kemampuan guru dalam berkomunikasi secara efektif juga manjadi penentu terhadap keberhasilan proses pembelajaran.Wayne K. Hoy (2008) mengatakan communication, in sum, is a relational process during which sources transmit messages using symbols, signs, and contextual cues to express meaning, to have receivers construct similiar understandings, and to influence behavior. Komunikasi merupakan proses relasional di mana sumber mengirimkan pesan dengan menggunakan simbol-simbol, tanda-tanda, dan sebuah isyarat untuk mengungkapkan makna, agar dapat mempengaruhi perilaku dan si penerima pesan dalam hal ini adalah siswa memiliki pemahaman serupa terhadap apa yang disampaikan oleh komunikator/penyampai pesan dalam hal ini adalah guru.

Untuk mengetahui sejauh mana tujuan pembelajaran telah tercapai, maka seorang guru perlu melakukan penilaian. Alan B. Knox (2002) mengatakan evaluation of material typically user citeria, guidelines and rubrics to assess various features that are important for assessing the quality of specific material maksudnya materi evaluasi biasanya digunakan sebagai pedoman untuk menilai kualitas tertentu. Guru harus bisa mengembangkan alat penilaian yang tepat untuk dapat mengukur kemajuan belajar dan hasil belajar dan memanfaatkan hasil penilaian

tersebut untuk melakukan perbaikan proses atau dapat digunakan untuk meningkatkan hasil pembelajaran, mendiagnosis kelemahan-kelemahan atau kesulitan yang dialami siswa selama proses pembelajaran berlangsung atau untuk menjadi bahan refleksi.

42 | Teknologi, informasi, dan Komuníkasi 
Selain memiliki kompetensi pedagogik sebagaimana yang diuraikan di atas, guru wajib memiliki kompetensi kepribadian yang utuh yang dapat dijadikan panutan dalam seluruh segi kehidupan. Dalam Permendiknas No. 16 tahun 2007 membagi indikator kompetensi kepribadian secara rinci ke dalam 5 sub kompetensi yaitu 1) bertindak sesuai norma agama, hukum, sosial dan kebudayaan yang berlaku 2) tampil sebagai pribadi yang jujur dan berakhlak mulia 3) menampilkan diri sebagai pribadi yang mantap 4) menunjukkan etos kerja dan tanggung jawab yang tinggi dan merasa bangga menjadi guru 5) menjunjung tinggi kode etik profesi guru.

Tenaga pendidik adalah ujung tombak dalam mencerdaskan kehidupan bangsa, melalui berbagai jenis, jalur dan jenjang pendidikan. Anak didik adalah anggota masyarakat yang akan masuk ke dalam dunia pendidikan (persekolahan) dan akan dikembalikan kepada masyarakatnya. Sekolah membekali siswa dengan ilmu pengetahuan, nilai-nilai agama dan nilai-nilai kehidupan, serta keterampilan hidup supaya mereka hidup dengan baik dalam masyarakat.

Guru sebagai tenaga profesional harus memiliki kode etik yang mengatur sikap dan perilaku profesionalitasnya. Kode etik merupakan pedoman sikap dan perilaku bagi anggota profesi dalam layanan professional maupun dalam hubungan dengan masyarakat. sehubungan dengan sikap dan prilaku guru, Sudarwan Danim (2010) mengatakan bahwa Kode etik merupakan norma dan asas yang disepakati dan diterima oleh guru sebagai pedoman sikap dan prilaku dalam melaksanakan tugas profesi sebagai pendidik, anggota 43 | Teknologi, Informasi, dan Komunikasi 
masyarakat dan warga negara. Pedoman sikap dan prilaku dimaksud adalah nilai-nilai moral yang membedakan perilaku guru yang baik dan buruk, yang boleh dan tidak boleh dilaksanakan selama menunaikan tugas-tugas profesionalitasnya untuk mendidik, mengajar, membimbing, mengarahkan, melatih, menilai dan mengevaluasi peserta didik serta pergaulan sehari-hari di dalam dan di luar sekolah.

Sesuai dengan perkembangan zaman dan teknologi, dimensi pengetahuan semakin meluas, maka seorang guru yang professional dituntut untuk mampu mengatasi perkembangan itu dengan meningkatkan profesionalitasnya. Peranan guru sangat menentukan dalam usaha peningkatan mutu pendidikan formal. Untuk itu guru sebagai agen pembelajaran dituntut mampu menyelenggarakan proses pembelajaran dengan sebaik-baiknya. Guru mempunyai fungsi dan peran yang sangat strategis, oleh karena itu perlu dikembangkan sebagai profesi yang bermartabat. Kemampuan guru dalam kegiatan pembelajaran memang sangat diperlukan.

Kegiatan proses pembelajaran, guru atau dosen (pendidik) sebagai figure sentral pengajar dan siswa sebagai subyek belajar, dituntut berperan dalam rangka mencapai tujuan pendidikan di sekolah. Bersamaan dengan itu, guru dan siswa dituntut dalam hal pengetahuan, sikap, agar proses belajar mengajar dapat terlaksana denagn efektif dan efisien. Dapat digambarkan proses belajar mengajar sebagai berikut.

44 |Teknologi, Informasi, dan Komuníkasi 


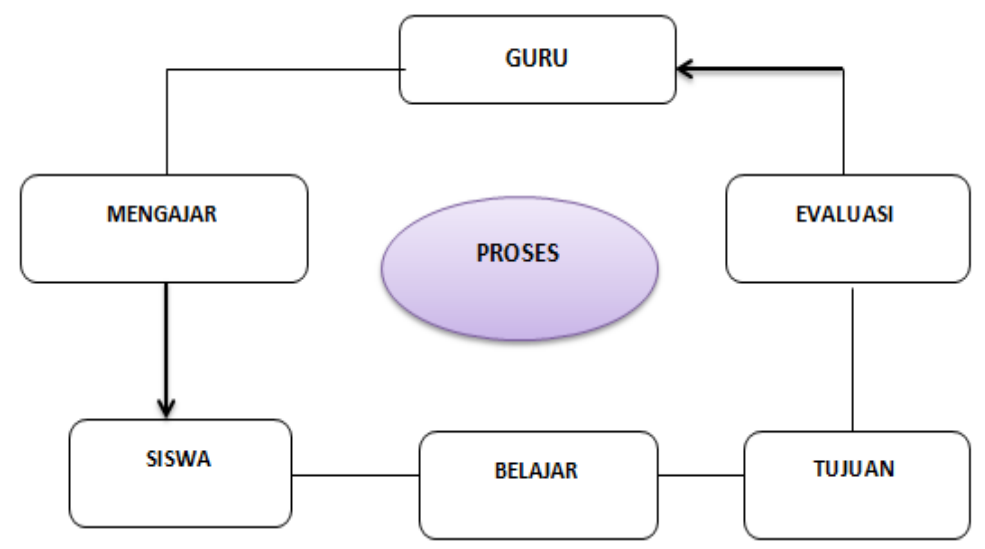

\section{Gambar 12. Interaksi edukatif guru dan siswa}

Menurut Makmun dalam Mukhtar (2012) proses pembelajaran merupakan suatu rangkaian interaksi anatara siswa dengan guru dalam rangkaian mencapai tujuannya. Maknanya terjadi perilaku belajar pada siswa dan perilaku mengajar pada pihak guru yang terjadi hubungan interaktif yang bersifat mengikat antara aktivitas kedua belah pihak.

Blended merupakan campuran, kombinasi yang baik. Sedangkan learning memiliki makna umum yakni belajar, dengan demikian sepintas mengandung makna pola pembelajaran yang mengandung unsur pencampuran, atau penggabungan antara satu pola dengan pola yang lainnya. Menurut Thorne (2003), blended learning adalah perpaduan dari teknologi multimedia, CD ROM, video streaming, kelas virtual, voicemail, email dan telefon conference, animasi teks online dan video-streaming.

45 | Teknologi, Informasi, dan Komunileasi 
Harding, Kaczynski dan Wood (2005) menyatakan blended learning merupakan pendekatan pembelajaran yang mengintegrasikan pembelajaran tradisonal tatap muka dan pembelajaran jarak jauh dengan menggunakan sumber belajar online dan beragam pilihan komunikasi yang dapat digunakan oleh guru dan siswa.

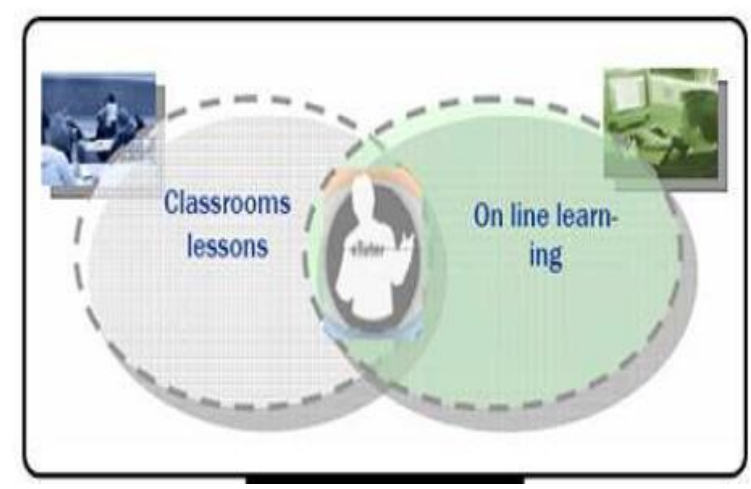

\section{Gambar 13. Sistem blended learning}

Pendekatan ini memungkinkan penggunaan sumber belajar online, terutama yang berbasis weblog, dengan tanpa meninggalkan kegiatan tatap muka. Dengan pelaksanaan blended learning ini, pembelajaran berlangsung lebih bermakna karena keragaman sumber belajar yang mungkin diperoleh. Secara sederhana dapat dikatakan bahwa blended learning adalah pembelajaran yang mengkombinasikan antara tatap muka (pembelajaran secara konvensional, dimana antara pelajar dan pengajar saling berinteraksi secara langsung, masing-masing dapat bertukar informasi mengenai bahanbahan pengajaran), belajar mandiri (belajar dengan berbagai modul yang telah disediakan) serta belajar mandiri secara

46 | Teknologi, Informasi, dan Komunikasi 
online. Sebuah penelitian yang dilakukan oleh Algozinne, dkk (2007) yang berjudul mengatakan "Ensuring a qualified teacher in every classroom is a central part of the latest agenda to strengthen public education and maximize student achievement. Effective teaching and delivering quality instruction are lifelong and critical goals of professional development of teachers". Hasil penelitian tersebut memastikan bahwa seorang guru yang berkualitas dalam tiaptiap kelas adalah suatu bagian terpenting untuk memperkuat pendidikan dan memaksimalkan prestasi siswa.

Pengajaran efektif dan pengiriman instruksi berkualitas adalah tujuan kritis dan kekal tentang pengembangan para guru profesional. Karena keberadaan guru yang profesional dapat meningkatkan prestasi siswa dan adanya output yang baik mampu meningkatkan kualitas sekolah. Proses belajar mengajar terhadap peran serta seorang guru sangatlah penting. Karena seorang guru dituntut untuk memiliki kemampuan yang baik dalam menyampaikan materi pelajaran. Tujuannya adalah agar materi yang disampaikan dapat diterima baik oleh para siswa. Sehingga pemahaman siswa dapat meningkat.

Salah satu bentuk profesional guru tersebut adalah keterampilan guru dalam pembelajaran yang merupakan keahlian dan kemampuan serta keahlian khusus dalam bidang keguruan sehingga ia mampu melakukan tugas dan fungsinya. Dapat juga dikatakan guru tersebut telah terdidik dan terlatih dengan baik, serta memiliki pengalaman yang kaya di bidang pembelajaran. Gusley (2002: 381) menyatakan "high quality professional development is a central component in nearly modern proposal for improving education. Policy makers 47 | Teknologi, informasi, dan Komunikasi 
increasingly recognize that schools can be no better than the teachers and administrators who work within them". (Kualitas pengembangan professional yang tinggi merupakan komponen utama dalam hamper setiap proposal modern untuk meningkatkan pendidikan. Para pembuat kebijakan semakin menyadari bahwa sekolah bisa tidak lebih baik dari para guru dan administrator yang bekerja dalam diri mereka).

48 | Teknologi, Informasi, dan Komunileasi 


\section{Rangkuman dan Soal}

1. Pendidik bukanlah satu-satunya sumber belajar. Sumber itulah yang nantinya dapat dijadikan sebagai penyalur atau penghubung pesan ajar yang diadakan dan atau diciptakan secara terencana oleh para guru atau pendidik yang biasa dikenal sebagai media pembelajaran. Media pembelajaran dijadikan sebagai penghubung antara guru dan siswa agar tercipta komunikasi yang efektif.

2. Media pembelajaran penting digunakan sebagai sarana alat yang dapat merangsang pikiran, perasaan, perhatian, dan minat siswa sehingga akan terjadi proses belajar yang berkualitas untuk mencapai kompetensi peserta didik yang diharapkan. Media merupakan salah satu komponen komunikasi, yaitu sebagai pembawa pesan dari komunikator menuju komunikan.

3. Penerapan media pembelajaran harus memperhatikan perkembangan jiwa keagamaan anak didik atau tingkat daya pikir anak didik. Hal ini karena adanya interaksi antara penggunaan media pembelajaran dan karakteristik gaya belajarnya.

4. Distance learning adalah suatu proses membawa informasi yang interaktif dan informasi pembelajaran yang ditujukan kepada siswa di suatu waktu, tempat dan tampilan (bentuk) yang tepat.

5. Blended learning merupakan pendekatan pembelajaran yang mengintegrasikan pembelajaran tradisonal tatap muka dan pembelajaran jarak jauh dengan menggunakan sumber belajar online dan beragam pilihan komunikasi yang dapat digunakan oleh guru dan siswa

49 | Teknologi, Informasi, dan Komunikasi 


\section{Latihan Soal}

1. Jelaskan maksud pernyatakan bahwa guru dan siswa dalam proses pembelajaran memiliki peran yang berubah-ubah karena adanya pengaruh teknologi?

2. Jelaskan apa yang dimaksud media merupakan salah satu komponen komunikasi yaitu sebagai pembawa pesan dari komunikator menuju komunikan?

3. Dalam kegiatan proses pembelajaran, guru atau dosen (pendidik) sebagai figure sentral pengajar dan siswa sebagai subyek belajar. Jelaskan maksudnya?

4. Jelaskan secara rinci tentang distance learning?

5. Apa dan bagaimana pelaksanaan dari program blended learning?

50 | Teknologi, Informasi, dan Komunikasi 


\section{BAB II \\ Memadukan Teknologi Dan Media Pembelajaran}

Bab ini menjelaskan tentang berbagai perbedaan konsep penerimaan informasi di antaranya melalui dua saluran informasi yang diterima oleh manusia, yakni berdasarkan modalitas sensori dan mode presentasi. Pendekatan modalitas sensori fokus pada apakah si peserta didik pada awalnya memproses materi melalui modal visual dan auditorinya. Menurut pendekatan modalitas sensori, satu saluran memproses materi yang terepresentasikan secara visual dan saluran lain memproses materi yang terepresentasikan secara auditori. Tampilnya lambang-lambang visual untuk memperjelas lambang verbal sehingga memungkinkan siswa lebih mudah memahami makna pesan yang disampaikan dalam proses pembelajaran. Hal ini disetbabkan bahwa visualisasi mencoba menggambarkan hakikat suatu pesan dalam bentuk yang menyerupai keadaan yang sebenarnya.

Bab ini lebih lanjut memberi perhatian khusus pada kolaborasi antara teknologi dan media pembelajaran inovatif, diantaranya

1. Karakteristik Pemrosesan Informasi

2. Strategi pembelajaran

3. Media pembelajaran inovatif

4. Klasifikasi Bahan Ajar

51 | Teknologi, Informasi, dan Komunikasi 


\section{A. Karakteristik Pemrosesan Informasi}

Pesan-pesan instruksional multimedia menawarkan teknologi pembelajaran yang berpotensi sangat kuat, yakni sistem untuk meningkatkan pembelajaran bagi manusia. Perbedaan terkait dengan multimedia learning terletak pada pemrosesan kata-kata tercetak (yakni teks on-screen) dengan suara-suara backgraound. Teks on-screen pada awalnya diproses dalam saluran verbal menurut pendekatan modalitas sensori (Mayer, 2009).

Pesan-pesan multimedia yang dirancang seiring dengan tata cara otak manusia bekerja akan lebih mungkin mengarah ke pembelajaran yang penuh arti, dibandingkan dengan pesan multimedia yang dirancang tidak seiring kerja otak manusia. Menurut Mayer (2009: 203), saat kata-kata disajikan sebagai narasi, saluran auditori bisa digunakan untuk pemrosesan kata-kata. Pada saat yang sama, saluran visual bisa digunakan untuk pemrosesan gambar-gambar. Dengan cara ini, bebannya jadi berimbang diantara dua saluran sehingga tidak ada satu saluran yang kelebihan beban. Gambar-gambar masuk melalui mata (di proses di saluran visual/pictorial) dan kata-kata terucapkan masuk lewat telinga (di proses di saluran auditori/verbal).

52 | Teknologi, Informasi, dan Komunikasi 
Multimedia Sensory

Presentation Memory

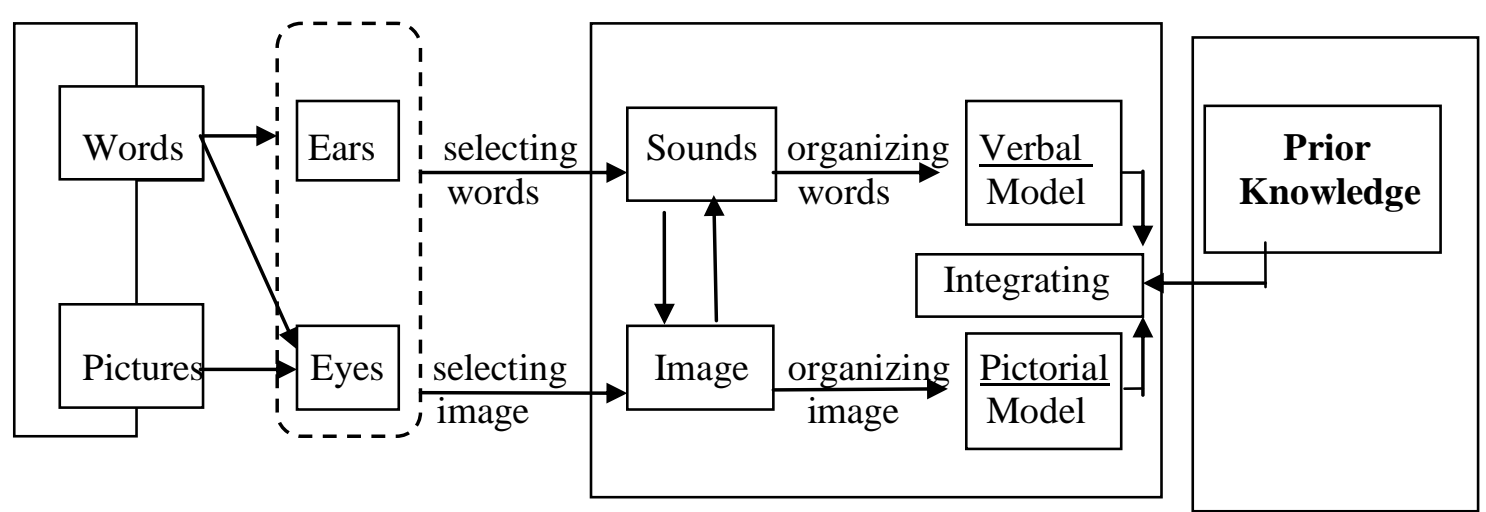

Gambar 14. Prinsip-prinsip multimedia learning
Long-Term

Memory

Working Memory

Prior 
Teori kognitif multimedia learning di atas didasarkan pada tiga asumsi dasar yakni: a) orang memiliki saluran auditori dan saluran visual yang terpisah, b) saluran-saluran itu memiliki kapabilitas yang terbatas, c) pembelajaran penuh makna itu melibatkan orang secara aktif memilih, menata dan memadukan informasi auditori dan visual yang masuk. Sebagaimana diungkapkan oleh Mayer (2009) dalam teori kognitif multimedia learning, bahwa peserta didik-peserta didik yang belajar dengan kata-kata dan gambar-gambar bisa menghasilkan $89 \%$ lebih banyak solusi kreatif dalam tes transfer dibandingkan peserta didik-peserta didik yang belajar dengan kata-kata saja. Saat kata-kata disajikan sebagai narasi, saluran auditori bisa digunakan untuk pemrosesan kata-kata. Pada saat yang sama, saluran visual bisa digunakan untuk pemrosesan gambar-gambar. Dengan cara ini, bebannya jadi berimbang diantara dua saluran sehingga tidak ada satu saluran yang kelebihan beban. Gambar-gambar masuk melalui mata (diproses disaluran pictorial) dan kata-kata terucapkan masuk lewat telinga (diproses disaluran verbal).

Adapun kegunaan sumber belajar sebenarnya tidak terlepas dari tujuan agar sumber belajar itu menjadi bermakna. Bahan ajar yang pendidik buat harus benar-benar diharapkan mampu membuat peserta didik menguasai kompetensi yang diharapkan. Dalam mencapai kriteria tersebut, seorang perancang pembelajaran atau pembang bahan ajar, bukan hanya membuat produk bahan ajar tetapi juga mengembangkan strategi pembelajaran, penyajian informasi, latihan dan umpan balik, pengujian dan kegiatan lanjutan. Strategi ditetapkan berdasarkan teori-teori

1 | Teknologi, informasi, dan Komunikasi 
pembelajaran, hasil-hasil penelitian, karakteristik media, isi dan karakteristik pebelajar yang menerima pembelajaran. Hafiz dalam penelitannya (2008) menyatakan tiga variabel utama pembelajaran adalah kondisi, metode dan hasil belajar. Dalam metode itu sendiri terdapat strategi penyampaian yang merupakan metode untuk menyampaikan pembelajaran.

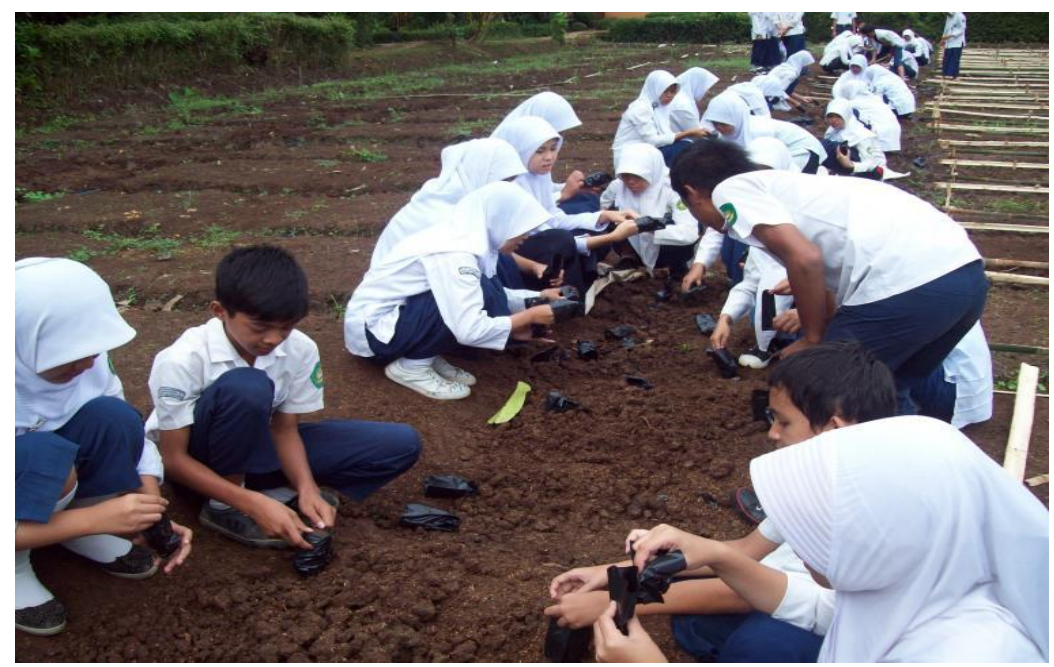

Gambar 15. Lingkungan sebagai sumber belajar

Gambar di atas menguatkan bahwa agar proses belajar mengajar dapat berhasil dengan baik, peserta didik sebaiknya diajak memanfaatkan semua alat inderanya. Guru sebaiknya berupaya menampilkan rangsangan (stimulus) yang dapat diproses dengan berbagai alat indera. Semakin banyak alat indera yang digunakan untuk menerima dan mengolah informasi, semakin besar pula kemungkinan informasi tersebut dapat dimengerti dan dapat dipertahankan dalam ingatan.

2 | Teknologi, Informasi, dan Komunikasi 
Ada beberapa manfaat yang bisa diperoleh dari kegiatan pembelajaran di luar kelas (outdoor study) dan memilki kelebihan yang mendukung pada pembelajaran siswa, di antaranya sebagai berikut: 1) mendorong motivasi belajar siswa, karena menggunakan setting alam terbuka sebagai sarana kelas, untuk memberikan dukungan pembelajaran secara menyeluruh yang dapat menambah aspek kegembiraan dan kesenangan; 2) guru mampu menciptakan suasana pembelajaran yang menyenangkan karena dapat bereksplorasi menciptakan suasana belajar seperti bermain; 3) mengasah aktivitas fisik dan kreativitas siswa karena menggunakan strategi belajar sambil melakukan atau mempraktikkan sesuai dengan penugasan.

Selain memiliki kelebihan, pendekatan di luar kelas sebagai pendekatan pembelajaran juga memiliki kelemahan yakni memerlukan perhatian yang ekstra dari guru pada saat pembelajaran karena menggunakan media yang sesuai dengan kenyataannya di luar sekolah sehingga memungkinkan peserta didik tidak serius dalam belajar.

\section{B. Strategi pembelajaran.}

Kegiatan merancang pembelajaran memerlukan pengetahuan yang bersifat kompleks, kreatif dan professional. Hal ini selaras dengan kompetensi merancang strategi pembelajaran yang merupakan bagian dari standar kompetensi pembelajar (guru). Kompetensi dalam merancang strategi pembelajaran yang dimaksud antara lain:

1. Strategi pengelolaan pembelajaran dalam penelitian Hafiz (2008) disebutkan tiga strategi pengelolaan

3 | Teknologi, Informasi, dan Komunileasi 
pembelajaran, diantaranya: 1) penjadwalan penggunaan strategi pengajaran, 2) pembuatan catatan kemajuan belajar siswa, 3) pengelolaan motivasi, dan 4) kontrol belajar dan juga penetapan strategi tepat digunakan dalam pembelajaran.

2. Strategi pengorganisasian pembelajaran, seorang desainer/pengembang perlu: 1) memahami dan mengorganisasikan kapabilitas belajar, dan 2) memaknai kondisi, 3) strategi kognitif, 4) sikap, dan 5) ketrampilan motorik.

3. Strategi penyampaian pembelajaran yang ideal dapat ditentukan atas beberapa hal berikut ini: 1) pertimbangan sasaran, karakteristik pebelajar, tujuan pembelajaran dan penilaian yang diperlukan, 2) meninjau kembali hasil analisis dan identifikasi tujuan pembelajaran, 3) merencanakan komponen pembelajaran, 4) menentukan kelompok pebelajar, 5) menentukan materi dan media, serta 6) memilih dan mengembangkan sistem yang terbaik untuk mempertimbangkan langkah dan keputusan yang telah dibuat.

4. Strategi penilaian pembelajaran menitikberatkan pada pembahasan metode, alat ukur dan instrument penilaian yang tepat untuk digunakan menilai, baik proses maupun hasil pembelajaran yang telah dilakukan dan dicapai oleh pebelajar. Adapun untuk pebelajar, penilaian pembelajaran berfungsi sebagai umpan balik untuk memperbaiki proses pembelajaran. Penilaian pembelajaran terkait erat dengan hasil belajar.

4 | Teknologi, informasi, dan Komunikasi 


\section{Media pembelajaran inovatif}

Untuk memahami maksud bahan ajar, kita dapat menelusuri pandangan dari beberapa ahli tentang pengertian istilah tersebut. Menurut National Centre for Competency Based Training dalam Andi Prastowo (2012), bahan ajar adalah segala bentuk bahan yang digunakan untuk membantu guru atau instruktur dalam melaksanakan pembelajaran dikelas. Dari pengertian tersebut dapat kita pahami bahwa bahan (baik informasi, alat, maupun teks) yang disusun secara sistematis, yang menampilkan sosok utuh dari kompetensi yang dikuasai peserta didik dalam kegiatan pembelajaran dengan tujuan perencanaan dan penelaahan implementasi pembelajaran. Bahan ajar merupakan sebuah susunan atas bahan-bahan yang berhasil dikumpulkan dan berasal dari berbagai sumber belajar yang dibuat secara sistematis. Untuk membuat bahan ajar yang baik setidaknya ada enam komponen yang perlu kita ketahui, diantaranya yaitu:

1. Petunjuk belajar, komponen pertama ini meliputi petunjuk bagi peserta didik dan pendidik. Didalamnya dijelaskan tentang bagaimana pendidik sebaiknya mengajarkan materi kepada siswa dan bagaimana pula peserta didik sebaiknya mmepelajari materi bahan ajar tersebut.

2. Kompetensi yang akan dicapai sebagai pendidik kita harus menjelaskan dan mencantumkan dalam bahan ajar tersebut dengan standart kompetensi, kompotensi dasar dan indikator pencapaian hasil yang harus dikuasai oleh peserta didik. Dengan demikian jelaslah tujuan yang harus dicapai oleh peserta didik.

5 | Teknologi, Informasi, dan Komunikasi 
3. Informasi pendukung merupakan berbagai informasi tambahan yang dapat melengkapi bahan ajar, sehingga siswa semakin mudah untuk menguasai pengetahuan yang akan mereka peroleh, selain itu pengetahuan siswapun akan semakin komprehensif.

4. Latihan merupakan suatu bentuk tugas yang diberikan kepada peserta didik untuk melatih kemampuan mereka setelah mempelajari bahan ajar. Dengan demikian kemampuan yang mereka pelajari akan semakin terasah dan terkuasai dengan matang.

5. Petunjuk kerja atau lembar kerja berisikan satu lembar atau beberapa lembar kertas yang berisi sejumlah langkah procedural cara pelaksanaan kegiatan tertentu yang harus dilakukan peserta didik.

6. Evaluasi terdiri atas sejumlah pertanyaan yang ditujukan kepada peserta didik untuk mengukur seberapa jauh penguasaan kompetensi yang berhasil mereka kuasaia setelah mengikuti proses pembelajaran.

\section{Klasifikasi Bahan Ajar.}

Bahan ajar memiliki klasifikasi dan bentuk. Namun demikian para ahli telah membuat kategori untuk macammacam bahan ajar sebagaimana yang diuraikan berikut ini (Prastowo, 2012)

1. Bahan ajar menurut bentuknya dibedakan menjadi empat macam, diantaranya:

a) Bahan cetak (printed) yakni sejumlah bahan yang disiapkan dalam kertas yang dapat berfungsi untuk keperluan pembelajaran atau penyampaian informasi.

6 | Teknologi, Informasi, dan Komunileasi 
b) Bahan ajar dengar (audio), yakni semua sistem yang menggunakan sinyal radio secara langsung, dapat didengar oleh seseorang atau sekelompok orang.

c) Bahan ajar pandang dengar (audiovisual), yakni segala sesuatu yang memungkinkan sinyal audio dapat dikombinasikan dengar gambar bergerak secara sekuensial.

d) Bahan ajar interaktif (interactive teaching material), yakni kombinasi dari dua atau lebih media (audio, visual, grafik, gambar, teks dan video) yang oleh penggunanya dimanipulasi atau diberi perlakuan untuk mengendalikan suatu perintah atau perilaku alami dalam suatu presentasi. Contohnya compact disk interactive.

2. Bahan ajar menurut cara kerjanya dibedakan menjadi lima macam, antara lain:

a) Bahan ajar yang tidak diproyeksikan, yakni bahan ajar yang tidak memerlukan proyektor untuk memproyeksikan isi di dalamnya, sehingga peserta didik bisa langsung (membaca, melihat dan mengamati) bahan ajar tersebut.

b) Bahan ajar yang diproyeksikan, yakni bahan ajar yang memerlukan proyektor agar bisa dimanfaatkan atau dipelajari oleh peserta didik. Misal penggunaan filmstrip dalam komputer dll.

c) Bahan ajar audio, yakni bahan ajar yang berupa sinyal audio yang direkam dalam suatu media rekam, untuk mempergunakannya harus menggunakan alat pemain (player) media rekam tersebut.

7 | Teknologi, Informasi, dan Komunikasi 
d) Bahan ajar video, yakni bahan ajar yang memerlukan alat pemutar yang biasanya berbentuk video tape player, VCD player, VCD player dll.

e) Bahan ajar (media) komputer, yakni berbagai jenis bahan ajar noncetak yang membutuhkan komputer untuk menayangkan. Contohnya komputer mediated instruction, komputer based multimedia dan sebagainya.

3. Bahan ajar menurut sifatnya dibagi menjadi empat macam, diantaranya:

a) Bahan ajar yang berbasis cetak, misalnya buku pamphlet, panduan belajar siswa, majalah, koran dll.

b) Bahan ajar yang berbasiskan teknologi, misalnya audio cassette, siaran radio, slide, filmstrips, video cassette, multimedia dll.

c) Bahan ajar yang digunakan untuk praktik atau proyek, missal kit sains, lembar bservasi, lembar wawancara dll.

d) Bahan ajar yang dibutuhkan untuk keperlan interaksi manusia, misalnya telepon, handpone, video conference dll.

8 |Teknologi, Informasi, dan Komunikasi 


\section{Rangkuman dan Soal}

1. Ada dua cara mengonsepkan perbedaan di antara dua saluran informasi yang diterima oleh manusia, yakni berdasarkan modalitas sensori dan mode presentasi. Pendekatan modalitas sensori fokus pada apakah si peserta didik pada awalnya memproses materi melalui matanya (misal: gambar, video, animasi dan kata-kata tercatak) atau telinganya (misal: kata-kata yang terucapkan dan suara backgraound). Menurut pendekatan modalitas sensori, satu saluran memproses materi yang terepresentasikan secara visual dan saluran lain memproses materi yang terepresentasikan secara auditori.

2. Terdapat tiga asumsi dasar tentang teori kognitif multimedia learning, yakni: a) orang memiliki saluran auditori dan saluran visual yang terpisah, b) saluransaluran itu memiliki kapabilitas yang terbatas, c) pembelajaran penuh makna itu melibatkan orang secara aktif memilih, menata dan memadukan informasi auditori dan visual yang masuk.

3. Teori kognitif multimedia learning menyatakan bahwa peserta didik-peserta didik yang belajar dengan katakata dan gambar-gambar bisa menghasilkan $89 \%$ lebih banyak solusi kreatif dalam tes transfer dibandingkan peserta didik-peserta didik yang belajar dengan katakata saja.

4. Bahan ajar merupakan sebuah susunan atas bahanbahan yang berhasil dikumpulkan dan berasal dari berbagai sumber belajar yang dibuat secara sistematis.

9 | Teknologi, informasi, dan Komunikasi 
Untuk membuat bahan ajar yang baik setidaknya ada enam komponen yang perlu kita ketahui, diantaranya yaitu: 1) petunjuk belajar, 2) kompetensi yang akan dicapai sebagai pendidik, 3) informasi pendukung, 4) latihan, 5) petunjuk kerja atau lembar kerja, 6) evaluasi terdiri atas sejumlah pertanyaan yang ditujukan kepada peserta didik.

5. Bahan ajar memiliki klasifikasi dan bentuk, diantaranya; 1) bahan ajar menurut bentuknya, 2) bahan ajar menurut kerjanya, dan 3) bahan ajar menurut sifatnya

\section{Latihan Soal}

1. Jelaskan secara rinci perbedaan makna antara modalitas sensori dan mode presentasi?

2. Jelaskan kaitannya tiga asumsi dasar dalam teori kognitif multimedia learning?

3. Jelaskan inti dari teori kognitif learning yang dikemukakan oleh Mayer?

4. Bahan ajar merupakan susunan atas bahan-bahan yang berhasil disusun dari berbagai sumber secara sistematis. Jelaskan komponen informasi pendukung yang dimaksud didalamnya?

5. Jelaskan perbedaan klasifikasi bahan ajar menurut bentuk, cara kerja dan sifatnya? 


\section{BAB III}

\section{Komunikasi Dalam Pembelajaran Berbasis ICT}

Bab ini menjelaskan tentang proses pengiriman informasi dari satu pihak kepada pihak lain untuk tujuan tertentu. Komunikasi dikatakan efektif apabila komunkasi yang terjadi menimbulkan arus informasi dua arah, yaitu dengan munculnya feedback dari pihak penerima pesan tersebut berkomunikasi. Banyak bukti menunjukkan bahwa komunikasi memegang peran penting dalam kehidupan manusia. Dapat dilihat berhasil atau tidaknya seseorang dalam membina hidup, berkarier, bahkan berpolitik tidak lepas dari kemampuan orang tersebut dalam berkomunikasi. Orang-orang besar tidak akan menjadi tokoh terkenal tanpa mereka mampu melakukan komunikasi dengan baik.

Rasullah Muhammad Saw, telah menjadi contoh konkret, panutan, sekaligus guru komunikasi terbaik dalam sejarah. Apa yang diucapkan Nabi adalah apa yang dikerjakan. Komunikasi verbal Rasullah senantiasa sesuai dengan komunikasi nonverbal atau tindakan beliau. Kejujuran antara ucapan dan tindakan itulah yang kemudian menyebabkan Muhammad disebut sebagai Al-Amin. Sebuah sebutan karena kredibilitas sebagai komunikator yang jujur.

Bab ini selanjutnya mengulas lebih mendalam tentang proses terjadinya komunikasi dalam pembelajaran berbasis ICT, diantaranya.

1. Komunikasi dan Pembelajaran

2. Proses Komunikasi dalam Pembelajaran

3. Komunikasi Efektif dalam Pembelajaran

4. Strategi Komunikasi Pembelajaran

11 | Teknologi, Informasi, dan Komunikasi 


\section{A. Komunikasi dan Pembelajaran \\ 1. Pengertian Komunikasi}

Ibrahim at-Taymi, berpendapat bahwa "seseorang mukmin ketika hendak berbicara, dia berpikir dahulu, jika bermanfaat diucapkan, jika tidak bermanfaat tidak diucapkan, sedangkan orang kafir (durhaka) lisannya mengalir saja”. Komunikasi merupakan tindakan melaksanakan kontak antara pengirim dan penerima, dengan bantuan pesan; pengirim dan penerima memiliki beberapa pengalaman bersama yang memberi arti pada pesan dan simbol yang dikirim oleh pengirim, dan diterima serta ditafsirkan oleh penerima. (Suranto: 2005).

Wilbur Schramm sebagaimana dikutip Elly (2007) menegaskan bahwa unsur utama dalam komunikasi mencakup lima unsur utama, yaitu komunikator, pesan, media, komunikan, dan efek. Tidak seluruh definisi dikemukakan di sini, tetapi berdasarkan definisi yang ada di atas dapat diambil pemahaman bahwa: pertama, Komunikasi pada dasarnya merupakan suatu proses penyampaian informasi. Dilihat dari sudut pandang ini, kesuksesan komunikasi bergantung pada desain pesan atau informasi dan cara penyampaiannya. Kedua, Komunikasi adalah proses penyampaian gagasan dari seseorang kepada orang lain. pengirim pesan atau komunikator memiliki peran yang paling menentukan dalam keberhasilan komunikasi, sedangkan komunikan atau penerima pesan hanya sebagai objek yang pasif. Ketiga, Komunikasi diartikan sebagai proses penciptaan arti terhadap gagasan atau ide yang disampaikan. Pemahaman ini menempatkan tiga komponen, yaitu pengirim, pesan, dan penerima pesan pada posisi yang seimbang. Proses 12 | Teknologi, Informasi, dan Komuníkasi 
ini menuntut adanya proses encoding oleh pengirim dan decoding oleh penerima sehingga informasi dapat bermakna.

Begitu juga halnya dengan kualitas pembelajaran, sangat dipengaruhi oleh efektif tidaknya komunikasi yang terjadi di dalamnya. Komunikasi efektif dalam pembelajaran kepada peserta didik, di mana peserta didik mampu memahami maksud pesan sesuai dengan tujuan Komunikasi efektif dalam pembelajaran kepada peserta didik, di mana peserta didik mampu memahami maksud pesan sesuai dengan tujuan yang telah ditentukan, sehingga menambah wawasan ilmu pengetahuan dan teknologi serta menimbulkan perubahan tingkah laku menjadi lebih baik. Guru yang dalam hal ini sebagai komunikator adalah pihak yang paling bertanggung jawab terhadap berlangsungnya komunikasi yang efektif dalam pembelajaran sehingga guru sebagai pengajar dituntut memiliki kemampuan berkomunikasi yang baik agar menghasilkan proses pembelajaran yang efektif.

\section{Pengertian Pembelajaran}

Pembelajaran adalah rangkaian peristiwa (events) yang mempengaruhi pembelajaran sehingga proses belajar dapat berlangsung dengan mudah (Gagne dan Brigga: 1979). Pembelajaran tidak hanya terbatas pada event-event yang dilakukan oleh guru, tetapi mencakup semua event yang mempunyai pengaruh langsung pada proses belajar yang meliputi kejadian-kejadian yang diturunkan dari bahan-bahan cetak, gambar, program radio, televisi, film, slide,maupun kombinasi dari bahan-bahan tersebut.

Sardiman AM (2005) dalam bukunya yang berjudul "Interaksi dan Motivasi dalam Belajar Mengajar" menyebut 13 | Teknologi, Informasi, dan Komunikasi 
istilah pembelajaran dengan interaksi edukatif. Menurut beliau, Menurut beliau, ang dianggap interaksi edukatif adalah interaksi yang dilakukan secara sadar dan mempunyai tujuan untuk mendidik, dalam rangka mengantar peserta didik ke arah kedewasaannya. Pembelajaran merupakan proses yang berfungsi membimbing para peserta didik di dalam kehidupannya, yakni membimbing mengembangkan diri sesuai dengan tugas perkembangan yang harus dijalani. Proses edukatif memiliki ciri-ciri: a) ada tujuan yang ingin dicapai; b) ada pesan yang akan ditransfer; c) ada pelajar; d) ada guru; e) ada metode; f) ada situasi ada penilaian.

Suatu sistem instruksional dan pola pengelolaan tertentu yang disunsun sebelumnya pada saat mendesain atau mengadakan pemilihan, dan pada saat menggunakan, untuk mewujudkan terjadinya proses belajar yang berarah tujuan dan terkontrol, dan yang: a) didesain untuk mencapai kompetensi tertentu atau tingkah laku akhir dari suatu pembelajaran; b) meliputi metodologi instruksional, format, dan urutan sesuai desain; c) mengelola kondisi tingkah laku; d) meliputi keseluruhan prosedur pengelolaan; e) dapat diulangi dan diproduksi lagi; f) telah dikembangkan mengikuti prosedur; g) telah divalidisi secara empirik. (Yusufhadi:1986)

14 | Telenologi, informasi, dan Komunikasí 


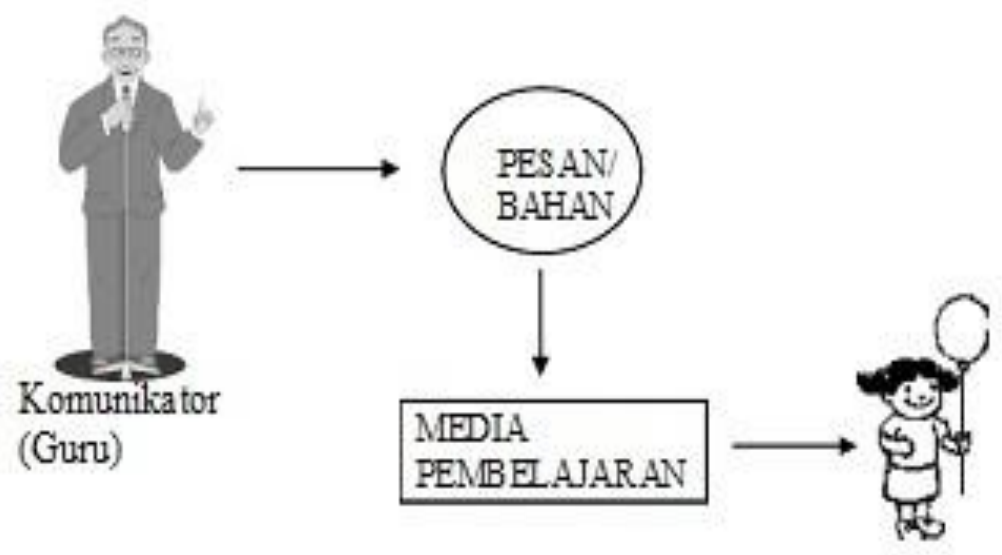

Gambar 16. Proses pembelajaran

Berdasarkan gambar di atas, secara sederhana, definisi pembelajaran (instruction) bermakna sebagai upaya yang dilakukan untuk membelajarkan seseorang atau kelompok orang melalui berbagai upaya (effort) dan berbagai strategi, metode, dan pendekatan ke arah pencapaian tujuan yang telah direncanakan. Pembelajaran dapat pula dipandang sebagai kegiatan guru secara terprogram dalam desain instruksional untuk membuat siswa belajar secara aktif yang menekankan pada penyediaan sumber belajar. Dengan demikian, pembelajaran pada dasarnya merupakan kegiatan terencana yang mengondisikan/merangsang seseorang agar bisa belajar dengan baik sesuai dengan tujuan pembelajaran. Oleh sebab itu, kegiatan pembelajaran akan bermuara pada dua kegiatan pokok. Pertama, bagaimana orang melakukan tindakan perubahan tingkah laku melalui kegiatan belajar. Kedua, bagaimana orang melakukan tindakan penyampaian ilmu pengetahuan melalui kegiatan mengajar. Hal ini menunjukkan 15 | Teknologi, informasi, dan Komunikasi 
bahwa makna pembalajaran merupakan kondisi eksternal kegiatan belajar, yang antara lain dilakukan oleh guru dalalm mengondisikan seseorang untuk belajar. Paparan di atas mengilustrasikan bahwa belajar merupakan proses internal siswa dan pembelajaran merupakan kondisi eksternal belajar. Dari segi guru belajar merupakan akibat tindakan pembelajaran.

Dalam pembelajaran terjadi proses komunikasi untuk menyampaikan pesan dari pendidik kepada peserta didik dengan tujuan agar pesan dapat diterima dengan baik dan berpengaruh terhadap pemahaman serta perubahan tingkah laku. Dengan demikian, keberhasilan kegiatan pembelajaran sangat bergantung pada efektivitas proses komunikasi yang terjada dalam pembelajaran tersebut.

\section{B. Proses Komunikasi dalam Pembelajaran \\ 1. Proses Komunikasi}

Komunikasi merupakan suatu proses yang melibatkan dua orang atau lebih dan di dalamnya terjadi pertukaran informasi dalam mencapai suatu tujuan tertentu. Komunikasi adalah suatu proses yang dinamis, bukan yang bersifat statis sehingga memerlukan tempat, menghasilkan perubahan dalam usaha mencapai hasil, melibatkan interaksi bersama, serta melibatkan suatu kelompok.

Dilihat dari pprosesnya, komunikasi dibedakan atas komunikasi verbal dan komunikasi nonverbal. Komunikasi verbal adalah komunikasi dengang menggunakan bahasa, baik bahasa tulis maupun bahasa lisan, sedangkan komunikasi nonverbal adalah komunikasi yang menggunakan isyarat, gerak-gerik, gambar, lambang, mimik muka, dan sejenisnya.

16 | Teknologi, Informasi, dan Komunikasi 
Ketercapaian tujuan merupakan keberhasilan komunikasi. Di dalam komunikasi terdapat 5 elemen yang terlibat, yaitu sender (pengiriman informasi), receiver (penerima informasi), informasi, feedback dan media. Kelima komponen tersebut dapat dilihat pada uraian di bawah ini.

a. Komunikator (pengirim pesan)

Komunikator merupakan sumber dan pengirim pesan. Kredibilitas komunikator yang membuat komunikan percaya terhadap isi pesan sangat berpengaruh terhadap keberhasilan komunikasi.

b. Pesan yang disampaikan

Pesan harus memiliki daya tarik tersendiri, sesuai dengan kebutuhan penerima pesan, adanya kesamaan pengalaman tentang pesan, dan ada peran dalam memenuhi kebutuhan penerima.

c. Komunikan (penerima pesan)

Agar komunikasi bejalan lancar, komunikan harus mampu manafsirkan pesan, sadar bahwa pesan sesuai dengan kebutuhannya, dan harus ada perhatian terhadap pesan yang diterima.

d. Konteks

Komunikasi belangsung dalam setting atau lingkungan tertentu. Lingkungan yang kondusif sangat mendukung keberhasilan komunikasi.

e. Sistem penyampaian

Sistem penyampaian berkaitan dengan metode dan media. Metode dan media yang digunakan dalam proses komunikasi harus disesuaikan dengan kondisi atau karakteristik penerima pesan

17 | Teknologi, informasi, dan Komunikasi 
Hal yang harus menjadi perhatian utama dan sering kita lupa adalah receiver (penerima informasi) dari PBM adalah manusia (siswa), maka sudah selayaknya seorang pendidik memperlakukan siswanya “ sebagia manusia”, jangan memperlakukan mereka sebagai mesin atau objek yang tidak memiliki perasaan. Pahami diri Anda sebagai seorang manusia untuk kemudian posisikan diri Anda ke dalam posisi siswa Anda, rasakan apa yang disenanginya, dan jauhi apa yang dibencinya. Sudah saatnya komunikasi Sudah saatnya komunikasi yang terjadi di dalam PBM merupakan sebuah komunikasi berkualitas yang mengedepankan rasa "kemanusiaan", dengan demikian akan tercapai sebuah kualitas dari komunikasi yang efektif yang akan berefek pada peningkatan kualitas diri setiap orang yang terlibat di dalamnya.

Unsur yang paling penting dalam komunikasi bukan sekedar pada apa yang kita tulis atau kita katakan, tetapi pada karakter kita dan bagaimana kita menyampaikan pesan kepada penerima pesan. Jadi syarat utama dalam komunikasi efektif adalah karakter yang kukuh yang dibangun dari integritas pribadi yang kuat. Integritas pribadi menghasilkan kepercayaan dan merupakan dasar jenis deposito yang berat. Integritas merupakan fondasi utama dalam membangun komunikasi yang efektif karena tidak ada persahabatan yang lebih dari sekedar kejujuran (honesty). Kejujuran mengatakan kebenaran atau menyesuaikan realitas dengan kata-kata kita dengan realitas.integritas adalah menyesuaikan realitas dengan kata-kata kita. Integritas bersifat aktif, sedangkan kejujuran besifat pasif. Seorang pendidik akan menjadi faktor yang terus disorot oleh siswa. Oleh karena itu, apabila Anda 18 | Teknologí, Informasi, dan Komunikasi 
seorang pendidik diharapkan bisa menjadi teladan yang baik bagi siswa dalam setiap perilakunya.

Dengan demikian, proses komunikasi dapat berlangsung satu arah dan dua arah. Komunikasi yang dianggap efektif adalah komunikasi yang menimbulkan arus informasi dua arah, yaitu dengan munculnya feedback dari penerima pesan. Dalam proses komunikasi yang baik akan terjadi tahapan pemaknaan terhadap pesan (meaning) yang akan disampaikan oleh komunikator, kemudian komunikator melakukan proses encoding, yaitu interpretasi atau mempersepsikan makna dari pesan tadi, dan selanjutnya dikirim kepada komunikan melalui channel yang dipilih. Pihak komunikan menerima informasi dari pengirim dengan melakukan proses decoding, yaitu menginterpretasi pesan yang diterima, dan kemudian memahaminya sesuai dengan maksud komunikator. Singkronisasi pemahaman antara komunikan dengan komunikator akan menimbulkan respons yang disebut dengan umpan balik.

\section{Desain Pesan dalam Pembelajaran}

Pembelajaran sebagai proses komunikasi dilakukan secara sengaja dan terencana, karena memiliki tujuan yang telah ditetapkan terlebih dahulu. Agar pesan pembelajaran yang ingin ditransformasikan dapat sampai dengan baik, maka Malcolm sebagaimana dikutip oleh Abdul Gaffur (2006) menyarankan agar guru-guru mendesain pesan pembalajaran dengan memperhatikan prinsip-prinsip sebagai berikut.

a. Kesiapan dan Motivasi

19 | Teknologi, Informasi, dan Komunikasi 
Kesiapan di sini mencakup kesiapan mental dan fisik. Motivasi terdiri dari motivasi internal dan eksternal, yang dapat ditumbuhkan dengan pemberian penghargaan, hukuman, serta deskripsi mengenai keuntungan an kerugian dari pembelajaran yang akan dilakukan.

b. Alat Penarik Perhatian

Pada dasarnya perhatian/konsentrasi manusia adalah jalang, sering berubah-ubah dan berpindah-pindah (tidak fokus) sehingga dalam mendesain pesan belajar, guru harus pandai-pandai membuat daya tarik, untuk mengendalikan perhatian siswa pada saat belajar. Pengendali perhatian yang dimaksud dapat berupa: warna, efek musik, pergerakan/perubahan, humor, kejutan, ilustrasi verbal dan visual, serta sesuatu yang aneh.

c. Partisipasi Aktif Siswa

Guru harus berusaha membuat peserta didik aktif dalam proses pembelajaran. Untuk menumbuhkan keaktifan siswa harus dimunculkan rangsangan-rangsangan, berupa tanya jawab, praktik dan latihan, drill, membuat rangkaian, kritik dan komentar, serta pemberian proyek (tugas).

d. Pengulangan

Agar peserta didik dapat menerima dan memahami materi dengan baik, maka penyampaian materi sebaiknya dilakukan berulang kali. Pengulangan dapat berupa pengulangan dengan metode dan media yang sama, pengulangan dengan metode dan media yang berbeda, preview, overview, atau penggunaan isyarat.

e. Umpan Balik

20 | Teknologi, Informasi, dan Komunikasi 
Dalam proses pembelajaran, sebagaimana yang terjadi pada komunikasi, adanya feedback merupakan hal yang penting. Umpan balik yang tepat dari guru dapat menjadi pemicu semangat bagi siswa. Umpan balik yang diberikan dapat berupa informasi kemajuan belajar siswa, penguatan terhadap jawaban benar, meluruskan jawaban yang keliru, memberi komentar terhadap pekerjaan siswa, dan dapat pula memberi impan balik yang menyeluruh terhadap performansi siswa.

f. Menghindari Materi yang Tidak Relevan

Agar materi pelajaran yang diterima peserta belajar tidak menimbulkan kebingungan atau bias dalam pemahaman, maka sedapat mungkin harus dihindari materi-materi yang tidak relevan dengan topik yang dibicarakan. Untuk itu, dalam mendesain pesan perlu diperhatikan bahwa yang disajikan hanyalah informasi yang penting, memberikan outline materi, memberikan konsep-konsep kunci yang akan dipelajari, membuang informasi distraktor, dan memberikan topik diskusi.

Desain pesan pembelajaran merupakan tahapan yang penting untuk dilakukan oleh guru, agar proses belajar mengajar berlangsung secara efektif. Dengan mendesain materi pelajaran terlebih dahulu, akan memudahkan guru dalam melaksanakan proses pembelajaran di kelas.

\section{Komunikasi Efektif dalam Pembelajaran}

Komunikasi dikatakan efektif apabila terdapat aliran informasi dua arah antara komunikator dan komunikan, dan informasi tersebut sama-sama direspons sesuai dengan harapan kedua pelaku komunikasi tersebut. Setidaknya

21 | Teknologi, informasi, dan Komunikasi 
terdapat lima aspek yang perlu dipahami dalam membangun komunikasi yang efektif. Kelima aspek tersebut adalah sebagai berikut.

1. Kejelasan; hal ini dimaksudkan bahwa dalam komunikasi harus menggunakan bahasa dan mengemas informasi secara jelas sehingga mudah diterima dan dipahami oleh komunikan.

2. Ketepatan; ketepatan atau akurasi ini menyangkut penggunaan bahasa yang benar dan kebenaran informasi yang disampaikan.

3. Konteks; konteks atau sering disebut dengan situasi, maksudnya adalah bahwa bahasa dan informasi yang disampaikan harus sesuai dengan keadaan dan lingkungan tempat komunikasi itu terjadi.

4. Alur; bahasa dan informasi yang akan disajikan harus disusun dengan alur atau sistematika yang jelas sehingga pihak yang menerima informasi cepat tanggap.

5. Budaya; aspek ini tidak saja menyangkut bahasa dan informasi, tetapi juga berkaitan dengan tatakrama dan etika.

Santoso Sastropoetro sebagaimana dikutip oleh (Riyono Pratikno: 1987) berkomunikasi efektif berarti bahwa komunikator dan komunikan sama-sama memiliki pengertian yang sama tentang suatu pesan,atau sering disebut dengan "the communication is in tune". Agar komunikasi dapat bejalan secara efektif, harus dipengaruhi beberapa syarat:

a) menciptakan suasana komunikasi yang menguntungkan;

b) menggunakan bahasa yang mudah ditangkap dan dimengerti;

22 | Teknologi, Informasi, dan Komunikasi 
c) pesan yang disampaikan dapat menggugah perhatian atau minat bagi pihak komunikan;

d) pesan dapat menggugah kepentingan komunikan yang dapat menguntungkan;

e) pesan dapat menumbuhkan suatu penghargaan bagi pihak komunikan.

Terkait dengan proses pembelajaran, komunikasi dikatakan efektif jika pesan yang dalam hal ini adalah materi pelajaran dapat diterima dan dipahami, serta menimbulkan umpan balik yang positif oleh siswa. Komunikasi efektif dalam pembelajaran harus didukung dengan keterampilan antarpribadi yang harus dimiliki oleh seorang guru. Komunikasi antarpribadi merupakan komunikasi yang berlangsung secara informal antara dua orang individu. Komunikasi ini berlangsung dari hati ke hati, karena di antara kedua belah pihak terdapat hubungan saling mempercayai. Komunikasi antarpribadi akan berlangsung secara efektif apabila pihak yang berkomunikasi menguasai keterampilan komunikasi. Hal ini sebagaimana firman Allah Swt dalam Q.S. Al Hujurat (49:13)
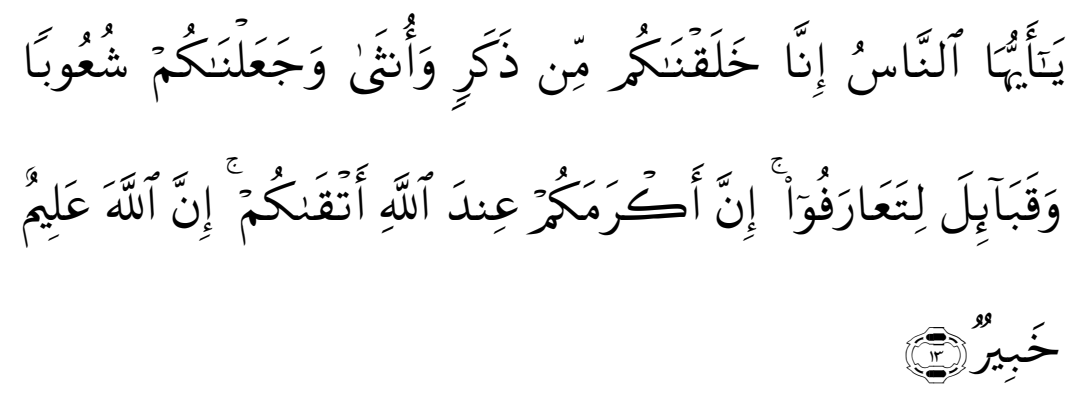

23 | Teknologi, Informasi, dan Komunikasí 
"Hai manusia, Sesungguhnya Kami menciptakan kamu dari seorang laki-laki dan seorang perempuan dan menjadikan kamu berbangsa - bangsa dan bersuku-suku supaya kamu saling kenal-mengenal. Sesungguhnya orang yang paling mulia diantara kamu disisi Allah ialah orang yang paling taqwa diantara kamu. Sesungguhnya Allah Maha mengetahui lagi Maha Mengenal”.

Ayat diatas menunjukkan bahwa saling mengenal yang dimaksudkan itu tidak membedakan suku, ras, bahasa, kebudayaan, bahkan ideologi. Maka, ketika manusia tidak peduli dengan lainnya, tidak mau saling mengenal atau dengan istilah lain lebih menonjolkan sikap egoistiknya, maka berarti ia telah kehilangan sifat dasar kemanusiaannya.

Dalam kegiatan belajar mengajar, komunikasi antarpribadi merupakan suatu keharusan, agar terjadi hubungan yang harmonis antara pengajar dengan peserta belajar. Keefektifan komunikasi dalam kegiatan belajar mengajar ini sangat bergantung pada kedua belah pihak. Namun, karena pengajar yang memegang kendali kelas, maka tanggung jawab terjadinya komunikasi dalam kelas yang sehat dan efektif terletak pada tangan pengajar. Keberhasilan pengajar dalam mengemban tanggung jawab tersebut dipengaruhi oleh keterampilannya dalam melakukan komunikasi ini.

\section{Hukum Komunikasi}

Untuk membangun komunikasi yang efektif, maka perlu memperhatikan Lima Hukum Komunikasi yang Efektif (The 5 Inevitable Laws of Effective Communcation), yang 24 |Teknologi, Informasi, dan Komunikasi 
disingkat REACH yang berarti merengkuh atau meraih. Karena komunikasi itu pada dasarnya adalah upaya bagaimana kita meraih perhatian, cinta kasih, minat, kepedulian, simpati, tanggapan, maupun respons positif dari orang lain (Elin Rusoni: 2006).

a. Hukum ke-1: Respect

Katakanlan, tiap-tiap orang berbuat menurut bakatnya (keadaannya) masing-masing. Maka tuhan-mu lebih mengetahui siapa yang lebih benar jalannya (Q.S. Al-Isra [17]: 84). Hukum pertama dalam mengembangkan komunikasi yang efektif adalah sikap menghargai setiap individu yang menjadi sasaran pesan yang kita sampaikan. Harus dipahami bahwa seorang pendidik harus bisa menghargai setiap siswa yang dihadapinya. Rasa hormat dan saling menghargai merupakan hukum yang pertama dalam kita berkomunikasi dengan orang lain. Sebagaimana firman Allah Swt:

"Hai manusia sesungguhnya kami menciptakan kamu sekalian dari seorang laki-laki dan seorang perempuan dan menjadikan kamu berbangsa-bangsa dan berkabilah-kabilah supaya kamu saling kenalmengenal. Sesungguhnya orang yang paling mulia di antara kamu di sisi Allah adalah orang yang paling bertaqwa di antara kamu. Sesungguhnya Allah Maha Mengetahui dan Maha Mengenal". (Q.S. Al Hujarat [49]: 13)

\section{b. Hukum ke-2: Empathy}

Dapat dikatakan bahwa Islam adalah agama empati, yakni agama yang mengajarkan pengikutnya untuk selalu merasakan apa yang dirasakan orang lain. Jika ada yang sakit 25 | Teknologi, informasi, dan Komunikasi 
di antara mereka, maka yang lain pun ikut merasakan sakitnya. Jika ada yang kurang beruntung, maka yang lain pun juga bisa merasakan bagaimana menjadi orang yang beruntung. Kepekaan empati Rasulullah ini disebutkan juga dalam salah satu ayat Al-Quran. Disebutkan bahwa telah datang kepadamu seorang Rasul dari bangsamu, yang sedih hatinya melihat penderitaanmu, yang senang melihat kamu bahagia, dan kepada orang mukmin beliau (Muhammad) penuh dengan kasih dan sayang. Inilah kepekaan kepemimpinan tulen yang membuat Nabi Muhammad dicintai umatnya sampai sekarang.

Empati adalah kemampuan kita untuk menempatkan diri kita pada situasi atau kondisi yang dihadapi oleh orang lain. salah satu prasyarat utama dalam memiliki sikap empati adalah kemampuan kita untuk mendengarkan atau mengerti terlebih dahulu sebelum didengarkan atau dimengerti oleh orang lain. Secara khusus kemampuan untuk mendengarkan sebagai salah satu dari 7 kebiasaan manusia yang sangat efektif, yaitu kebiasaan untuk mengerti terlebih dahulu, baru dimengerti. Inilah yang disebut dengan komunikasi empatik. Dengan memahami dan mendengarkan orang lain terlebih dahulu, kita dapat membangun keterbukaan dan kepercayaan yang kita perlukan dalam membangun kerja sama atau sinergi dengan orang lain. rasa empati akan memampukan kita untuk dapat menyampaikan pesan (message) dengan cara dan sikap yang akan memudahkan penerima pesan (reciever) menerimanya.

Oleh karena itu, dalam ilmu pemasaran (marketing), memahami perilaku konsumen, kita dapat empati dengan apa yang menjadi kebutuhan, keinginan, minat, harapan, dan 26 | Teknologi, Informasi, dan Komunikasi 
kesenangan dari konsumen. Demikian halnya dengan bentuk komunikasi di dunia pendidikan. Kita perlu saling memahami dan mengerti keberadaan, perilaku, dan keinginan siswa. Rasa empati akan menimbulkan respek atau penghargaan, dan rasa respek akan membangun kepercayaan yang merupakan unsur utama dalam membangunsebuah suasana kondusif di dalam proses belajar-mengajar. Jadi, sebelum kita membangun komunikasi atau mengirimkan pesan, kita perlu mengerti dan memahami empati calon penerima pesan kita sehingga nantinya pesan kita akan dapat tersampaikan tanpa ada halangan psikolog atau penolakan dari penerima.

c. Hukum ke-3: Audible (Dimengerti)

Makna audible, antara lain: dapat didengarkan atau dimengerti dengan baik. Jika empati berarti kita harus mendengar terlebih dahulu ataupun mampu menerima umpan balik dengan baik, maka audible berarti pesan yang kita sampaikan dapat diterima oleh penerima pesan. Hukum ini mengatakan bahwa pesan harus disampaikan melalui media atau delivery channel sehingga dapat diterima dengan baikoleh penerima pesan. Hukum ini mengacu pada kemampuan kita untuk menggunakan berbagai media maupun perlengkapan atau alat bantu audio-visual yang akan membantu kita agar pesan yang kita sampaikan dapat diterima dengan baik. Sebagaimana sabda Rasulullah: "Bagi segala sesuatu itu ada metodenya, dan metode masuk surga adalah ilmu".

d. Hukum ke-4: Clarity (Jelas)

Bahasa adalah alat komunikasi antar manusia. Kita telah menemukan bahwa terdapat perbedaan dalam cara-cara orang berbicara. Ada berbicara panjang lebar, padahal 27 | Teknologi, informasi, dan Komunileasi 
informasi yang didapat sedikit saja, sementara ada yang memiliki pengetahuan yang banyak, tetapi membutuhkan kekuatan untuk mengungkapkan dan menyampaikannya. Bahkan ada yang memperpanjang pembicaraan, sementara dia tahu bahwa hal itu bisa diringkas tanpa menghilangkan sedikitpun inti dari pembicaraannya. Rasulullah telah memberikan contoh/teladan tentang bagaimana cara menyampaikan pesan sebagaimana diriwayatkan oleh sayyidah Aisyah: "Rasulullah tidak berbicara dengan sambung-menyambung seperti yang kalian lakukan ini. Akan tetapi, pembicaraan Rasulullah terpisah-pisah dengan jeda. Jika seseorang menghitung kata-katanya, tentu ia dapat menghitungnya, sedangkan jika Rasulullah mengucapkan satu kalimat, dia mengulanginya sebanyak tiga kali agar dapat diingat."

Selain dapat dimengerti dengan baik, maka hukum keempat yang terkait dengan itu adalah kejelasan dari pesan itu sendiri sehingga tidak menimbulkan multiinterpretasi atau berbagai penafsiran yang lainnya. Clarity dapat pula berarti keterbukaan dan transparasi. Dalam berkomunikasi kita perlu mengembangkan sikap terbuka (tidak ada yang ditutupi atau disembunyikan) sehingga dapat menimbulkan rasa percaya (trust) dari penerima pesan. Karena tanpa keterbukaan akan timbil sikap saling curiga dan pada gilirannya akan menurunkan semangat dan antusiasme siswa dalam proses belajar-mengajar.

Tujuan pembelajaran harus disampaikan dengan jelas, sistematis dan teratur, serta didukung oleh penggunaan alat bantu peraga jika memang diperlukan. Semakin siswa merasakan mendapatkan banyak ilmu dari Anda, maka siswa 28 | Teknologi, Informasi, dan Komunikasi 
akan semakin terpacu untuk terus menghadiri dan memperhatikan pelajaran yang Anda sampaikan. Dengan cara seperti ini siswa tidak akan menganggap lagi proses belajarmengajar sebagai formalitas, tetapi akan menganggapnya sebagai sebuah kebutuhan pokok bagi kehidupannya.

e. Hukum ke-5: Humble (Rendah Hati)

Hukum kelima dalam membangun komunikasi yang sangat efektif adalah sikap rendah hati. Sikap ini merupakan unsur yang terkait dengan hukum pertama untuk membengun rasa menghargai orang lain, biasanya didasari oleh sikap rendah hati yang kita miliki.

Pada kitab "Ta'lim al-Muta'allim" terdapat syair tentang kerendahan hati yang berbunyi :

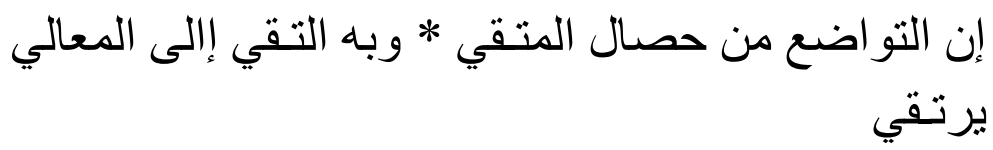

Sesungguhnya rendah hati adalah salah satu ciri orang yang bertaqwa. Dengannya, orang yang bertaqwa mencapai derajat kemuliaan.

Nabi Muhammad Saw. juga telah memerintahkan kita untuk selalu bersikap rendah hati. Dalam sebuah hadis beliau bersabda : Sesungguhnya Allah Swt. telah mewahyukan kepadaku agar beliau bertawadu',sehingga tak seorang pun menyombongkan diri kepada yang lain, atau seseorang tiada menganiaya kepada yang lainnya. (H.R. Muslim)

Ketika ditanya mengenai arti tawadu' (rendah hati), alFudhail menjawab, "kamu tunduk kepada kebenaran dan 29 | Teknologi, Informasi, dan Komunikasi 
patuh kepadanya. Walaupun engkau mendengarnya dari anak kecil, engkau tetap menerimanya. Bahkan, meskipun engkau mendengarnya daari orang terbodoh, engkau tetap menerimanya". Hal terakhir yang harus ada di dalam diri para pendidik adalah sikap mental yang dipenuhi semangat dan kesungguhan. Semua teori yang disebutkan di atas tidak akan cukup berat jika memang tidak dibarengi dengan sebuah kesungguhan dan semangat yang kita singkat dengan SOUL (4 spirit for SOUL).

\section{1) Spirit for $\underline{\text { Servicing }}$}

Hal ini mungkin menjadi sesuatu yang sering dilupakan insan pendidikan. Pekerjaan mulia yang ada di hadapan sering kali tidak dibungkus dengan sebuah semangat yang tulus untuk melayani. Melayani peserta didik tercinta, melayani orang yang memberikan kepercayaan kepada Anda, melayani cikal bakal kader bangsa colon penyelamat bangsa untuk keluar dari krisis. Munculkan semangat ini dalam diri Anda, semangat yang lebih untuk melayani.

2) Spirit for giving an Outstanding Performance

Semangat melayani saja tidak cukup, Anda sebagai insan pendidikan harus berani menaikkan level pelayanan Anda menjadi pelayanan dengan semangat memberikan Outstanding Performance semangat memberikan hasil yang terbaik bagi semua tugas dan pelayanan yang menjadi amanah Anda.

3) Spirit for Understanding

Hal selanjutnya yang tidak kalah penting adalah semangat yang tulus yang muncul dari dalam diri untuk lebih

30 | Teknologi, Informasi, dan Komunikasi 
mendengarkan dan mengerti keinginan siswa yang Anda didik.

\section{4) Spirit for Loving}

Kemudian, munculkanlah semangat untuk lebih mencintai siswa seperti mencintai anak sendiri, dan cintai diri mereka seperti kita mencintai diri sendiri. Lakukan hal ini, maka siswa akan melihat ketulusan kita untuk kemudian akan bersama-sama dengan kita meraih kesuksesan dalam proses belajar-mengajar,

Komunikasi yang efektif dalam proses pembelajaran sangat berdampak terhadap keberhasilan pencapaian tujuan. Komunikasi dikatakan efektif apabila terdapat aliran informasi dua arah antara komunikator dan komunikan dan informasi tersebut sama-sama direspons sesuai dengan harapan kedua pelaku komunikasi tersebut. Jika dalam pembelajaran terjadi komunikasi yang efektif antara pengajar dengan siswa, maka dapat dipastikan bahwa pembelajaran tersebut berhasil. Sehubungan dengan hal tersebut, maka para pengajar, pendidik, atau instruktur pada lembaga-lembaga pendidikan atau pelatihan harus memiliki kemampuan komunikasi yang baik. Kemampuan komunikasi yang dimaksud dapat berupa kemampuan memahami dan mendesain informasi, memilih dan menggunakan saluran atau media, serta kemampuan komunikasi antarpribadi dalam proses pembelajaran.

\section{Ketrampilan Diskusi Kelompok}

Diskusi kelompok adalah suatu proses yang teratur yang melibatkan sekelompok orang dalam interaksi tatap muka yang informal dengan berbagai pengalaman atau 31 |Teknologi, Informasi, dan Komunikasi 
informasi, pengambilan kesimpulan, atau pemecahan masalah. Diskusi kelompok merupakan strategi yang memungkinkan siswa menguasai suatu konsep atau memecahkan suatu masalah melalui satu proses yang memberi kesempatan untuk berpikir, berinteraksi sosial, serta berlatih bersikap positif. Dengan demikian, diskusi kelompok dapat meningkatkan kreativitas siswa, serta membina kemampuan berkomunikasi. Keterampilan membimbing diskusi kelompok kecil bertujuan sebagai berikut.

1. Siswa dapat saling memberi informasi atau pengalaman dalam menjelajahi gagasan baru atau masalah yang harus dipecahkan mereka.

2. Siswa dapat mengembangkan pengetahuan dan kemampuan untuk berpikir dan berkomunikasi.

3. Siswa terlibat dalam perencanaan dan pengambilan keputusan.

Komponen-komponen keterampilan membimbing diskusi adalah sebagai berikut.

a) Memusatkan perhatian siswa pada tujuan dan topik diskusi. Aspek-aspek yang dapat dilakukan adalah sebagai berikut.

1) Rumuskan tujuan dan topik yang akan dibahas pada awal diskusi.

2) Kemukakan masalah-masalah khusus.

3) Catat perubahan atau penyimpangan diskusi dari tujuan.

4) Rangkum hasil pembicaraan diskusi.

b) Memperjelas masalah maupun usulan/pendapat. Aspaekaspek yang dapat dilakukan adalah sebagai berikut.

1) Merangkum usulan tersebut sehingga menjadi jelas.

32 | Teknologi, Informasi, dan Komunikasí 
2) Meminta komentar siswa dengan mengajukan pertanyaan-pertanyaan yang membantu mereka memperjelas atau mengembangkan ide tersebut.

3) Menguraikan gagasan siswa dengan memberi informasi tambahan atau contoh-contoh yang sesuai sehingga kelompok dapat memperoleh informasi secara lebih jelas.

c) Menganalisis pandangan/pendapat siswa. Di dalam diskusi sering terjadi perbedaan pendapat di antara anggota kelompok. Dengan demikian, guru hendaknya mampu menganalisis alasan perbedaan tersebut dengan cara sebagai berikut.

1) Meneliti apakah alasan tersebut memang mempuyai dasar yang kuat.

2) Menjelaskan hal-hal yang disepakati maupun yang tidak disepakati.

d) Meningkatkan usulan siswa. Aspek-aspek yang dapat dilakukan adalah sebagai berikut.

1) Mengajukan pertanyaan-pertanyaan yang menantang siswa untuk berpikir.

2) Memberikan contoh-contoh verbal yang sesuai secara tepat.

3) Memberikan waktu untuk berpikir.

4) Memberikan dukungan kepada usulan pendapat siswa dengan penuh perhatian.

e) Menyebarkan kesempatan berpartisipasi. Aspek-aspek yang dapat dilakukan adalah sebagai berikut.

1) Mencobah memancing usulan siswa yang enggan berpartisipasi dengan mengarah langsung secara bijaksana.

33 | Teknologi, informasi, dan Komunikasi 
2) Mencegah terjadinya pembicaraan serentak dengan memberi giliran kepada siswa yang pendiam terlebih dahulu.

3) Secara bijaksana mencegah siswa yang suka memonopoli pembicaraan.

4) Mendorong siswa untuk mengomentari usulan temannya sehingga interaksi antarsiswa dapat ditingkatkan.

f) Menutup diskusi. Aspek-aspek yang dapat dilakukan adalah sebagai berikut.

1) Dengan bantuan para siswa, membuat rangkuman hasil diskusi.

2) Memberi gambaran tentang tindak lanjut hasil diskusi.

3) Mengajak siswa untuk menilai proses maupun hasil diskusi yang telah tercapai.

Ketrampilan membimbing diskusi kelompok kecil memiliki dua prinsip. Pertama, diskusi hendaknya berlangsung dalam "iklim terbuka". Hal ini ditandai dengan adanya keantusiasan berpartisipasi, kehangatan hubungan antarpribadi, kesediaan menerima dan mengenal lebih jauh topik diskusi, dan kesediaan menghargai pendapat orang lain. Dengan demikian, semua anggota kelompok mempunyai keinginan untuk dikenal dan dihargai, dapat merasa aman dan bebas mengemukakan pendapat. Kedua, perlu perencanaan dan persiapan yang matang, yaitu: 1) topik yang dipilih hendaknya sesuai dengan tujuan yang akan dicapai, minat, dan kemampuan siswa; 2) masalah hendaknya mengandung jawaban yang kompleks, bukan jawaban yang tunggal; 3) adanya informasi pendahuluan yang berhubungan dengan topik tersebut agar para siswa memiliki latar belakang 34 | Teknologi, informasi, dan Komunikasi 
pengetahuan yang sama sehingga mampu pemberikan penjelasan dan pertanyaan-pertanyaan yang dapat memotivasi siswa.

\section{Ketrampilan Mengelola Kelas}

Pengelolaan kelas adalah keterampilan guru untuk menciptakan dan memelihara kondisi belajar optimal dan mengembalikannya bila terjadi gangguan dalam proses belajar mengajar. Dalam melaksanakan keterampilan mengelola kelas, maka perlu diperhatikan komponen keterampilan yang berhubungan dengan penciptaan dan pemeliharaan kondisi belajar yang optimal (bersifat preventif) berkaitan dalam kemampuan guru dalam mengambil inisiatif dan mengendalikan pelajaran, dan bersifat represif, keterampilan yang berkaitan dengan respons guru terhadap gangguan siswa yang berkelanjutan dengan maksud agar guru dapat mengadakan tindakan remedial untuk mengembalikan kondisi belajar yang optimal. Komponen keterampilan mengelola kelas terbagi dua.

1. Keterampilan yang berhubungan dengan penciptaan dan pemeliharaan kondisi belajar yang optimal, meliputi halhal berikut ini.

a) Menunjukkan sikap tanggap. Sikap tanggap ini dapat ditunjukkan oleh guru untuk membuktikan bahwa ia ada bersama dengan para siswanya, memberikan perhatian, sekaligus mengontrol kepedulian dan ketidakacuhan para siswanya. Sikap tanggap ini dapat dilakukan dengan cara memandang secara seksama, gerak mendekati, memberi pertanyaan sserta 35 | Teknologi, Informasi, dan Komunikasí 
memberikan reaksi atas gangguan dan ketidakacuhan siswa dalam bentuk teguran.

b) Membagi perhatian. Pengelolaan kelas yang efektif dapat terjadi jika guru mampu membagi perhatian kepada beberapa kegiatan dalam waktu yang sama dengan cara berikut ini.

1) Visual, mengalihkan pandangan dari satu kegiatan ke kegiatan yang lain dengan kontak pandang terhadap kelompok siswa atau seorang siswa secara individual.

2) Verbal, dengan cara memberikan komentar, penjelasan, pertanyaan dan sebagainya terhadap aktivitas seorang siswa sementara ia memimpin kegiatan siswa yang lain.

c) Memusatkan perhatian kelompok. Kegiatan siswa dalam belajar dapat dipertahankan jiak guru mampu memusatkan perhatian siswa untuk melakukan tugas secara berkelompok atau bekerja sama. Memusatkan dapat dilakukan dengan cara berikut ini.

1) Memberikan tanda, misalnya dengan menciptakan atau membuat situasi tentang hal sebelum menyampaikan materi.

2) Menuntut tanggung jawab, atas keterlibatan siswa dalam suatu kegiatan, baik dalam melaporkan hasil kerja kelompok, memperagakan sesuatu atau memberikan tanggapan.

d) Memberikan petunjuk-petunjuk yang jelas. Guru harus sering kali memberikan arahan dan petunjuk yang jelas dalam proses pembelajaran, sehingga siswa tidak kebingungan.

36 |Teknologi, Informasi, dan Komunikasi 
e) Menegur. Apabila terjadi penyimpangan dan pelanggaran tingkah laku siswa sehingga menggangu proses pembelajaran di dalam kelas, guru hendaknya memberikan teguran dengan memperhatikan hal-hal sebagai berikut.

1) Tegas dan jelas tertuju kepada siswa yang mengganggu.

2) Menghindari peringatan yang kasar dan menyakitkan.

3) Menghindari ocehan atau ejekan, lebih-lebih yang berkepanjangan.

f) Memberi penguatan. Untuk menanggulangi siswa yang mengganggu atau tidak melakukan tugas, maka penguatan dapat diberikan sesuai dengan masalah yang muncul.

2. Keterampilan berhubungan dengan pengembalian kondisi belajar yang optimal, meliputi.

1) Modifikasi perilaku. Modifikasi perilaku menurut Bootzin yang dikutip dalam Soetarlinah Soekadji (1983) merupakan usaha untuk menerapkan prinsipprinsip proses belajar maupun prinsip-prinsip psikologi hasil eksperimen lain pada perilaku manusia.

2) Melakukan pendekatan pemecahan masalah kelompok.

3) Memperlancar terjadinya kerja sama yang baik dalam pelaksanaan tugas.

4) Memelihara kegiatan-kegiatan kelompok.

5) Menemukan dan memecahkan tingkah laku yang menimbulkan masalah. Seorang guru harus

37 | Teknologi, informasi, dan Komunikasi 
memaksimalkan untuk memecahkan masalah tersebut dengan seperangkat cara untuk mengendalikan perilaku siswa tersebut.

\section{Strategi Komunikasi Pembelajaran}

Dalam berkomunikasi. Seorang komunikator dalam hal ini adalah guru harus dapat menggunakan perasaan/emosi dalam menghadapi audiensnya karena audien/peserta didik adalah makhluk yang berperasaan. Sebagaimana Allah menciptakan hati sebagai tempat bersemayamnya perasaan emosi (aathifah). Allah membagi emosi manusia menjadi dua kutub, yaitu baik dan buruk, seperti juga yang perna dikatakan Sigmund Freud (Ellys, 2012) yaitu emosi positif (libido), seperti kasih sayang, haru, senang, dan gembira; dan emosi negatif (thanatos), seperti marah, benci, takut yang berlebihan, dan sedih yang berlebihan.

Lebih lanjut Ellys (2012) mengemukakan bahwa emosi pada diri komunikator dapat dikenali sebagai berikut.

1. Lembut; menurut Freud dalam hipotesis agresi-frustasi manusia dinyatakan bahwa orang-orang akan muncul emosi negatifnya seperti marah ketika dihalangi dalam memenuhi kebutuhannya dan gembira bila keinginannya tercapai. Seorang komunikator harus menghimpun emosi positif dengan memperbanyak maaf, rasa terima kasih, penghargaan dan kekuatan terhadap audiensnya. Pada hakikatnya, seorang komunikator bukanlah memiliki kekuasaan yang tinggi dan kekuatan fisik yang hebat, tetapi memiliki pengendalian diri saat marah. Firman Allah Swt QS. Ali Imran (134):

38 | Teknologi, Informasi, dan Komunikasi 

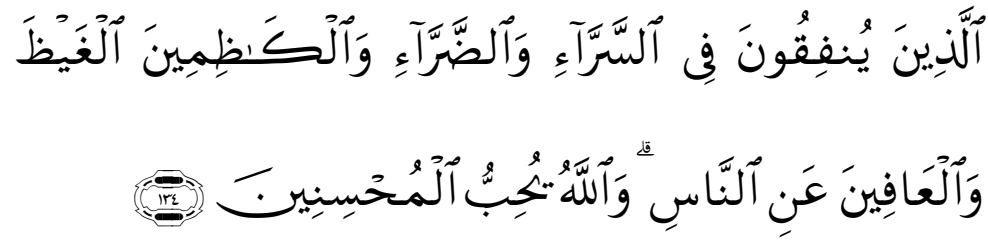

" (yaitu) orang-orang yang menafkahkan (hartanya), baik di waktu lapang maupun sempit, dan orang-orang yang menahan amarahnya dan mema'afkan (kesalahan) orang. Allah menyukai orang-orang yang berbuat kebajikan" Abu Huraira pun meriwayatkan bahwa Rasulullah pernah bersabda, "orang yang kuat bukanlah yang menang gulat, tetapi orang yang mampu menahan diri ketika ia marah (shur'ah)." (H.R. Bukhari)

2. Kasih sayang; Aristoteles menyarankan agar seorang komunikator mempunyai sikap hangat kepada audiensnya. Perasaan permusuhan hendaknya diubah menjadi solidaritas. Sebagaimana sabda Rasulullah:

"Kecerdasan akal sesudah beriman adalah yang menuntun pelakunya berbuat kasih sayang kepada sesama manusia dan dapat diandalkan dalam berpendapat tanpa bantuan orang lain. sesungguhnya orang yang ahli kebaikan di dunia, maka adalah ahli kebaikan di akhirat dan sesungguhnya ahli kemunkaran di dunia mereka adalah ahli kemunkaran di akhirat."

3. Percaya diri; rasa ketakutan biasanya datang dari gambaran mental tentang adanya bencana-bencana yang dapat terjadi. Oleh karena itu, seorang komunikstor harus dapat menjelaskan suatu peristiwa yang dapat dibuktikan dan tidak abstrak atau absurd. Kepercayaan dapat

39 | Teknologi, Informasi, dan Komunikasi 
dibangun oleh penjelasan bahwa bahaya itu jauh dari diri kita. Karena itu, seorang komunikator harus dapat menghilangkan rasa takut yang tidak beralasan dan hanya kepada Allah-lah ia pantas takut, tiada yanf lain. takut kepada Allah dan kukuh dengan keyakinan pada kekuatan-nya, artinya iman telah bertahta dalam diri si komunikator. Sebagaimana firman Allah Swt:
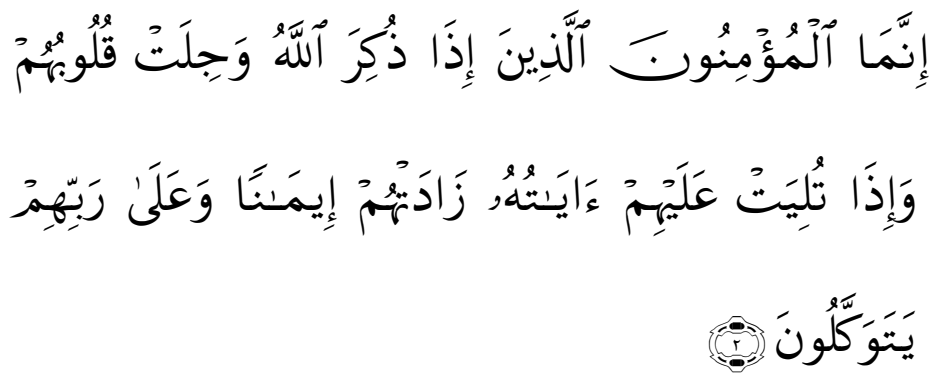

"Sesungguhnya orang beriman itu adalah mereka yang apabila disebut nama Allah gemetarlah hati mereka, dan apabila dibacakan ayat-ayat-nya bertambahlah iman mereka (karenanya) dan kepada tuhan-mulah mereka bertawakal." (Q.S. al-anfal [8]:2).

Apabilah rasa takut kepada Allah sudah tertanam dalam hati, maka akan tegaklah kepercayaan diri pada diri komunikator/guru. Sikap percaya diri seorang guru tentu saja sangat dibutuhkan karena untuk dapat meyakinkan umat atau khalayak harus didahului oleh adanya keyakinan pada diri sendiri.

4. Rasa malu; seorang guru sekaligus komunikator tidak boleh merasa malu terhadap kelemahan dan kekurangannya. Rasa malu boleh hinggap bila akan melakukan hal-hal yang negatif dan merugikan orang lain.

40 |Teknologi, Informasi, dan Komunikasi 
rasa malu positif sebagai tali kekang guru bertindak berlebihan dan tidak sesuai dengan ajaran Rasulullah yang tentunya akan memalukan dirinya sebagai guru/komunikator. Diriwayatkan dari Umar bin Hashim bahwa Rasulullah perna bersabda: malu positif tidak akan mendatangkan sesuatu apa pun selain kebaikan. (H.R. Bukhari).

5. Pujian; pada diri manusia sebenarnya terdapat sense of fairness (rasa keadilan). Seorang harus menjadiakn iman sebagai penopang hidupnya, dan ia tidak akan melontarkan ucapan-ucapan yang membuat kebencian atau penghinaan kepada orang lain. Dan Allah akan menjaga lisannya untuk selalu menebarkan kata-kata yang dapat dirasa hormat dan pujian dari sesama. Sebagaimana Allah berfirman dalam surat An-Nisa'[4]: ayat 19:
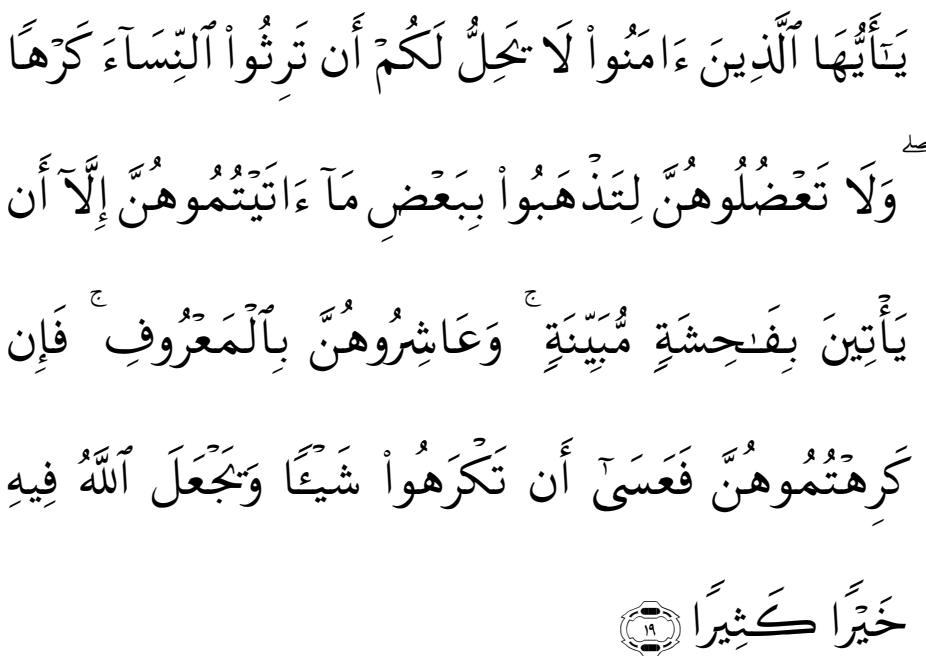

"Hai orang-orang yang beriman, tidak halal bagi kamu mempusakai wanita dengan jalan paksa dan janganlah

41 | Teknologi, Informasi, dan Komunikasi 
kaтu menyusahkan mereka karena hendak mengambil kembali sebagian dari apa yang telah kamu berikan kepadanya, terkecuali bila mereka melakukan pekerjaan keji yang nyata. dan bergaullah dengan mereka secara patut. kemudian bila kamu tidak menyukai mereka, (maka bersabarlah) karena mungkin kamu tidak menyukai sesuatu, Padahal Allah menjadikan padanya kebaikan yang banyak.

Ayat ini tidak menunjukkan bahwa mewariskan wanita tidak dengan jalan paksa dibolehkan. menurut adat sebahagian Arab Jahiliyah apabila seorang meninggal dunia, Maka anaknya yang tertua atau anggota keluarganya yang lain mewarisi janda itu. janda tersebut boleh dikawini sendiri atau dikawinkan dengan orang lain yang maharnya diambil oleh pewaris atau tidak dibolehkan kawin lagi.

6. Kasih sayang/belas kasih; guru sebagai komunikator yang mempunyai belas kasihan kepada peserta didiknya, akan mendapat atau menerima balasan kasih sayang pula. Dari Abu Huraira r.a. berkata: 'saya mendengar Rasulullah Saw. bersabda': 'Allah menciptakan rasa kasih sayang itu 100 bagian. 99 bagian itu disimpan-Nya di sisi-Nya (dan diberikan kelak di surga) 1 bagian saja yang Allah turunkan ke dunia ini. Dengan 1 bagian itu para makhluk seluruhnya saling menyayangi".

Untuk menciptakan suasana hubungan baik dan harmonis antara guru dengan peserta didik dan antarkomponen lainnya, ada banyak cara yang bisa dilakukan. Di antaranya dengan mengembangkan proses pembelajaran aktif bahwa proses belajar terjadi di dalam diri orang yang

42 | Teknologi, informasi, dan Komuníkasi 
belajar. Menurut ahli pendidikan, peserta didik yang belajar sudah memiliki pengetahuan ataupun pengalaman sebelumnya yang dapat dikembangkan. Melalui belajar aktif, para siswa dapat berinteraksi dengan sesamanya, dengan objek, fenomena alam, lingkungan, dan manusia serta hal ini memungkinkan mereka untuk merefleksikan, merekayasa ulang dalam upaya mengembangkan pengetahuan dan pengalaman yang diperoleh sebelumnya untuk menghasilkan yang lebih baru. Ketika proses ini terjadi, di sinilah proses belajar terjadi. Teknik-teknik belajar aktif dibangun berdasarkan cara-cara orang belajar secara alamiah. Mereka belajar secara alami dengan menemukan sendiri melalui uji coba baik pengalaman langsung maupun pengalaman kedua, seperti dengan membaca, mendengarkan orang lain. proses belajar biasanya terjadi pada saat mereka berinteraksi dan berkomunikasi dengan sesama teman, antara orang yang belajar dengan guru.

43 |Teknologi, Informasi, dan Komunikasí 


\section{Rangkuman dan Soal}

1. Unsur utama dalam komunikasi mencakup lima unsur utama, yaitu komunikator, pesan, media, komunikan, dan efek.

2. Komunikasi pada dasarnya merupakan suatu proses penyampaian informasi. Dilihat dari sudut pandang ini, kesuksesan komunikasi bergantung pada desain pesan atau informasi dan cara penyampaiannya.

3. Komunikasi adalah proses penyampaian gagasan dari seseorang kepada orang lain. pengirim pesan atau komunikator memiliki peran yang paling menentukan dalam keberhasilan komunikasi, sedangkan komunikan atau penerima pesan hanya sebagai objek yang pasif.

4. Pengelolaan kelas adalah keterampilan guru untuk menciptakan dan memelihara kondisi belajar optimal dan mengembalikannya bila terjadi gangguan dalam proses belajar mengajar. Dalam melaksanakan keterampilan mengelola kelas, perlu diperhatikan komponen keterampilan yang berhubungan dengan penciptaan dan pemeliharaan kondisi belajar yang optimal (bersifat preventif) berkaitan dalam kemampuan guru dalam mengambil inisiatif dan mengendalikan pelajaran, dan bersifat represif, keterampilan yang berkaitan dengan respons guru terhadap gangguan siswa yang berkelanjutan dengan maksud agar guru dapat mengadakan tindakan remedial untuk mengembalikan kondisi belajar yang optimal.

5. Komunikasi diartikan sebagai proses penciptaan arti terhadap gagasan atau ide yang disampaikan.

44 | Teknologi, informasi, dan Komunikasi 
Pemahaman ini menempatkan tiga komponen, yaitu pengirim, pesan, dan penerima pesan pada posisi yang seimbang. Proses ini menuntut adanya proses encoding oleh pengirim dan decoding oleh penerima sehingga informasi dapat bermakna.

6. Komunikasi dikatakan efektif apabila terdapat aliran informasi dua arah antara komunikator dan komunikan dan informasi tersebut sama-sama direspons sesuai dengan harapan kedua pelaku komunikasi tersebut. Jika dalam pembelajaran terjadi komunikasi yang efektif antara pengajar dengan siswa, maka dapat dipastikan bahwa pembelajaran tersebut berhasil.

7. Ketrampilan membimbing diskusi kelompok kecil memiliki dua prinsip, yakni 1) diskusi berlangsung dalam "iklim terbuka", 2) diskusi perlu perencanaan dan persiapan yang matang

\section{Latihan Soal}

1. Jelaskan secara rinci menyangkut unsur utama dalam komunikasi mencakup lima unsur utama, yaitu komunikator, pesan, media, komunikan, dan efek?.

2. Jelaskan bahwa komunikasi merupakan suatu proses penyampaian informasi?

3. Dalam proses komunikasi dikenal dengan istilah komunikan pasif dan komunikan aktif, jelaskan perbedaan keduanya?

4. Proses komunikasi menuntut adanya encoding dan decoding. Jelaskan makna keduanya?

45 | Teknologi, informasi, dan Komunikasi 
5. Ketrampilan membimbing diskusi kelompok kecil memiliki dua prinsip, yakni 1) iklim terbuka; dan 2) perencanaan. Jelaskan maksud keduanya?

46 | Teknologi, Informasi, dan Komunikasi 


\section{BAB IV \\ Media Pembelajaran Kontekstual Berbasis TIK}

Bab ini membahas tentang semakin sadarnya orang akan pentingnya media yang membantu pembelajaran sudah mulai dirasakan. Pengelolaan alat bantu pembelajaran sudah sangat dibutuhkan. Bahkan pertumbuhan ini bersifat gradual. Metamorfosis dari perpustakaan yang menentukan pada penyediaan media cetak, menjadi penyediaan permintaan dan pemberi layanan secara multi-sensori dari beragamnya kemampuan individu untuk menyerap informasi, menjadikan pelayanan yang diberikan mutlak wajib bervariatif dan secara luas. Selain itu, dengan semakin meluasnya kemajuan dicabang komunikasi dan teknologi, serta ditemukannya dinamika proses belajar, maka pelaksanaan kegiatan pendidikan dan pengajaran semakin menuntut dan memperoleh media pendidikan yang bervariasi secara luas. Karena memang belajar adalah proses internal dalam diri manusia maka guru bukanlah merupakan satu-satunya sumber belajar, namun merupakan salah satu komponen dari sumber belajar yang disebut.

Saat ini teknologi komputer tidak lagi hanya digunakan sebagai sarana komputasi dan pengolahan kata (word processor) tetapi juga sebagai sarana belajar multi media yang memungkinkan peserta didik membuat desain dan rekayasa suatu konsep dan ilmu pengetahuan. Sajian multimedia berbasis komputer dapat diartikan sebagai teknologi yang mengoptimalkan peran komputer sebagai sarana untuk menampilkan dan merekayasa teks, grafik, dan 47 | Teknologi, informasi, dan Komunikasi 
suara dalam sebuah tampilan yang terintegrasi. Dengan tampilan yang dapat mengkombinasikan berbagai unsur penyampaian informasi dan pesan, komputer dapat dirancang dan digunakan sebagai media teknologi yang efektif untuk mempelajari dan mengajarkan materi pembelajaran kepada peserta didik.

Bab ini akan menjelaskan secara rinci mengenai media pembelajaran kontekstual berbasis teknologi, informasi, dan komunikasi, diantaranya meliputi.

1. Media Pembelajaran Berbasis Komputer

2. Strategi Pembelajaran Dengan TIK

3. Pemanfaatan Microsoft Power Point untuk Pembelajaran

4. Inovasi Teknologi Informasi dan Komunikasi

\section{A. Media Pembelajaran Berbasis Komputer}

Kemajuan media komputer memberikan beberapa kelebihan untuk kegiatan produksi audio visual. Pada tahun tahun belakangan komputer mendapat perhatian besar karena kemampuannya yang dapat digunakan dalam bidang kegiatan pembelajaran. Ditambah dengan teknologi jaringan dan internet, komputer seakan menjadi primadona dalam kegiatan pembelajaran. Dalam proses pembelajaran, mengapa perlu sebuah media?. Pertanyaan ini sering dipertanyakan mengingat pentingnya penggunaan media dalam sebuah pembelajaran. Untuk itu kita harus mengetahui dahulu pengertian konsep abstrak dan konkrit dalam proses komunikasi, penyampaian pesan dari pengantar ke penerima. Pesan berupa isi yang dituangkan ke dalam simbol-simbil komunikasi baik verbal maupun non-verbal, proses ini

48 |Teknologi, Informasi, dan Komunikasi 
dinamakan encording. Penafsiran symbol-simbol komunikasi tersebut oleh siswa dinamakan decording.

Aplikasi komputer dalam bidang pembelajaran memungkinkan berlangsungnya proses belajar secara individual (individual learning). Pemakai komputer atau user dapat melakukan interaksi langsung dengan sumber informasi. Perkembangan teknologi komputer jaringan (computer network/Internert) saat ini telah memungkinkan pemakainya melakukan interaksi dalam memperoleh pengetahuan dan informasi yang diinginkan. Berbagai bentuk interaksi pembelajaran dapat berlangsung dengan tersedianya medium komputer dalam memberikan umpan balik (feedback) yang segera kepada pemakainya.

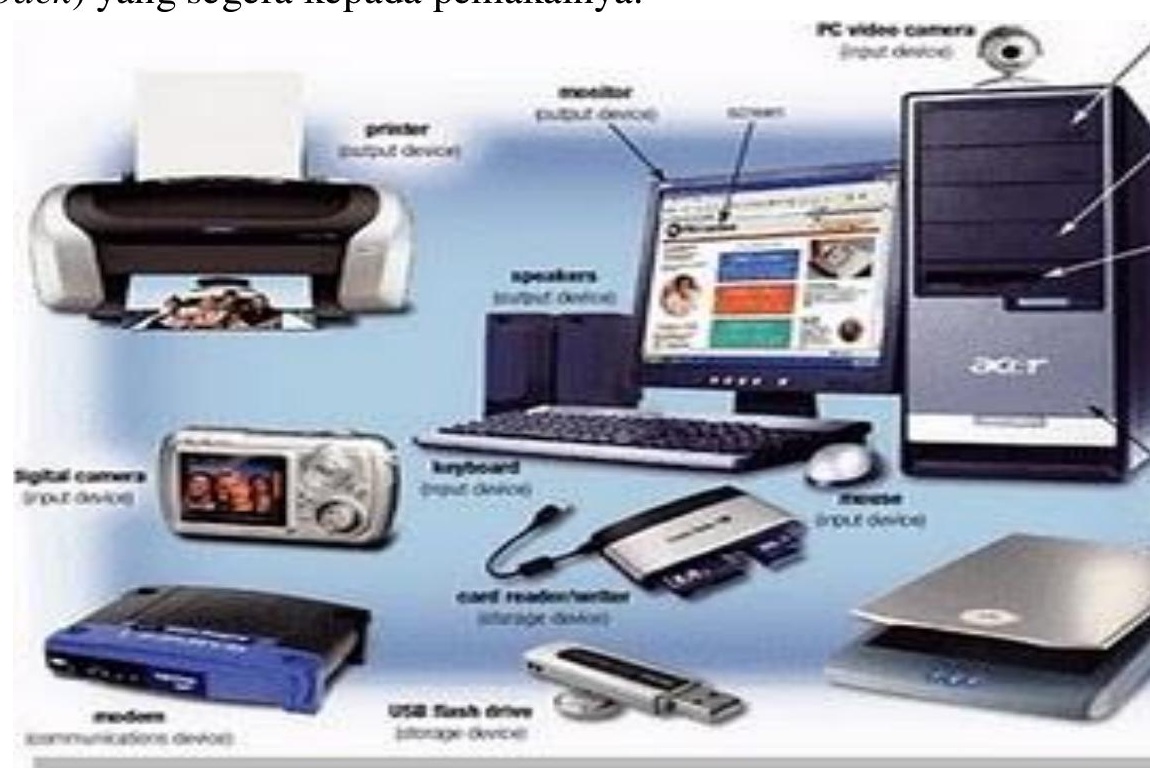

\section{Gambar 17. Media pembelajaran berbasis komputer}

Gambar diatas menjelaskan bahwa selama proses pembelajaran berlangsung ada kalanya penafsiran yang 49 | Teknologi, Informasi, dan Komunikasi 
dimiliki peserta didik berhasil dan ada kalanya tidak. Kegagalan atau ketidak berhasilan komunikasi dalam memahami apa yang didengar, dibaca, dilihat atau diamati dikenal dengan istilah barriers noise. Semakin banyak verbalisme, maka semakin abstrak pemahanan yang diterima. Karateristik dan kemampuan masing-masing media perlu diperhatikan oleh guru agar mereka dapat memilih media mana yang sesuai dengan kondisi dan kebutuhan. Sebagai contoh mesin kaset audio merupakan mesin auditif yang mengajarkan topik-topik pembelajaran yang bersifat verbal seperti pengucapan (pronounciation) bahasa asing. Untuk pengajaran bahasa asing media ini tergolong tepat karena bila secara langsung diberikan tanpa media sering terjadi ketidaktepatan yang akurat dalam pengucapan pengulangan dan sebagainya.

Pembelajaran efektif berkaitan langsung dengan keberhasilan pencapaian pengalaman belajar. Pembelajaran efektif menguatkan pratek dalam tindakan. Pembelajaran efektif mengintegrasikan komponen-komponen kurikulum inti. Pembelajaran efektif bersifat dinamis dan dapat membangkitkan kagairahan. Pembelajaran efektif merupakan perpaduan antara seni dan ilmu tentang pengajaran. Pembelajaran efektif membutuhkan pemahaman komprehensif tentang siklus pembelajaran. Pembelajaran efektif dapat menemukan sekspresi terbaiknya ketika guru berkolaborasi untuk mengembangkanya, mengimplementasikan, dan menemukan bentuk praktek mengajar yang professional.

Sejumlah variabel sebaiknya dijadikan pertimbangan ketika guru menyeleksi model pembelajaran, strategi, dan 50 |Teknologi, Informasi, dan Komunikasi 
metode-metode yang akan digunakan. Variabel-variabel tersebut diantara lain: 1) hasil dan pengalaman belajar siswa yang diinginkan; 2) urutan pembelajaran (sequence) yang selaras : dedukatif atau induktif; 3) tingkat pilihan dan tanggung jawab siswa (degree); 4) pola interaksi yang memungkinkan; dan 5) keterbatasan praktek pembelajaran yang ada.

\section{B. Strategi Pembelajaran Dengan TIK}

Muhamad Fuad Athman (2006) mengatakan istilah 'strategi' adalah berasal dari kata 'stratego' (perkataan greek) yang bermaksud saluran-saluran yang ada bagi ketenteraan. Dalam Kamus Besar Bahasa Indonesia arti kata strategi yaitu: "Ilmu dan seni dalam menggunakan semua sumber daya yang ada untuk melaksanakan kebijaksanaan negara tertentu". Strategi adalah rencana yang cermat mengenai kegiatan untuk mencapai sasaran khusus. Istilah strategi menurut The International Webster's Student Dictionary of The English Language mengandung arti 'the science of planning and conducting military campaigns on a broad scale; skill in management; an ingeniuous plan or method' (Ilmu perencanaan dan pelaksanaan gerakan militer secara luas; keahlian dalam manajemen; rencana yang cermat atau metode).

Table 2. Strategi mengolah materi berbasis komputer

\begin{tabular}{|c|c|c|}
\hline No & $\begin{array}{c}\text { Strategi Mengolah } \\
\text { Materi }\end{array}$ & Keterangan \\
\hline 1 & Seleksi buku & $\begin{array}{lcc}\text { Memilih buku yang } & \text { akan } \\
\text { menjadi acuan } & & \text { dengan } \\
\text { mempertimbangkan is materi, } & \text { isi } \\
\text { tingkat kesulitan, metodologi }\end{array}$ \\
\hline
\end{tabular}

51 | Teknologi, Informasi, dan Komunikasi 


\begin{tabular}{|c|c|c|}
\hline & & $\begin{array}{l}\text { instruksional, dan integritas } \\
\text { keilmuan } \\
\text { Penulis }\end{array}$ \\
\hline 2 & Strukturalisasi & $\begin{array}{l}\text { Strukturisasi diawali dengan } \\
\text { membuat proposisi dari teks dasar. } \\
\text { Setelah menentukan proposisi } \\
\text { utama, makro, dan mikro, langkah } \\
\text { selanjutnya adalah } \\
\text { mengalihkannya ke bentuk online, } \\
\text { sehingga didapat sebuah model } \\
\text { presentasi teks. }\end{array}$ \\
\hline 3 & Seleksi materi & $\begin{array}{l}\text { Tidak semua materi yang ada } \\
\text { dalam topic/materi diperlukan } \\
\text { oleh siswa. Oleh karena itu, } \\
\text { dibutuhkan pemilihan kembali } \\
\text { terhadap materi yang sesuai } \\
\text { dengan tuntutan kurikulum. }\end{array}$ \\
\hline 4 & Reduksi & 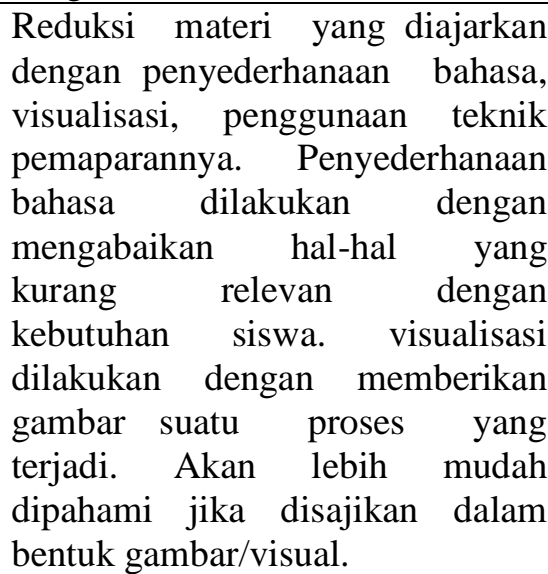 \\
\hline
\end{tabular}

Sistem komputer dapat menyampaikan pembelajaran secara individual maupun klasikal secara langsung kepada para siswa dengan cara berinteraksi dengan mata pelajaran yang diprogramkan ke dalam sistem komputer, inilah yang disebut dengan pembelajaran berbasis komputer.

52 | Teknologi, Informasi, dan Komunikasi 
Pembelajaran dengan komputer ini dapat membantu pencapaian pembelajaran secara tuntas dan efisien. Selain itu juga guru dapat melatih siswa secara terus menerus sampai ketuntasan pembelajaran tercapai dengan baik. Penggunaan komputer dalam pembelajaran juga dapat melatih keterampilan siswa dalam menggunakan komputer dengan seoptimal mungkin. Sehingga daya tangkap dengan materi yang terima pun juga lebih baik. Siswa pun akan secara cepat memperoleh penguasaan dan keterampilan yang diharapkan. Dengan mengembangkan strategi pengolahan materi pembelajaran berbasis komputer dapat memperluas kesempatan peserta didik untuk belajar, meningkatkan efisiensi, meningkatkan kualitas belajar, meningkatkan kualitas mengajar, memfasilitasi pembentukan keterampilan, mendorong belajar sepanjang hayat berkelanjutan, meningkatkan perencanaan kebijakan dan manajemen, serta mengurangi kesenjangan digital.

53 | Teknologi, Informasi, dan Komunikasi 


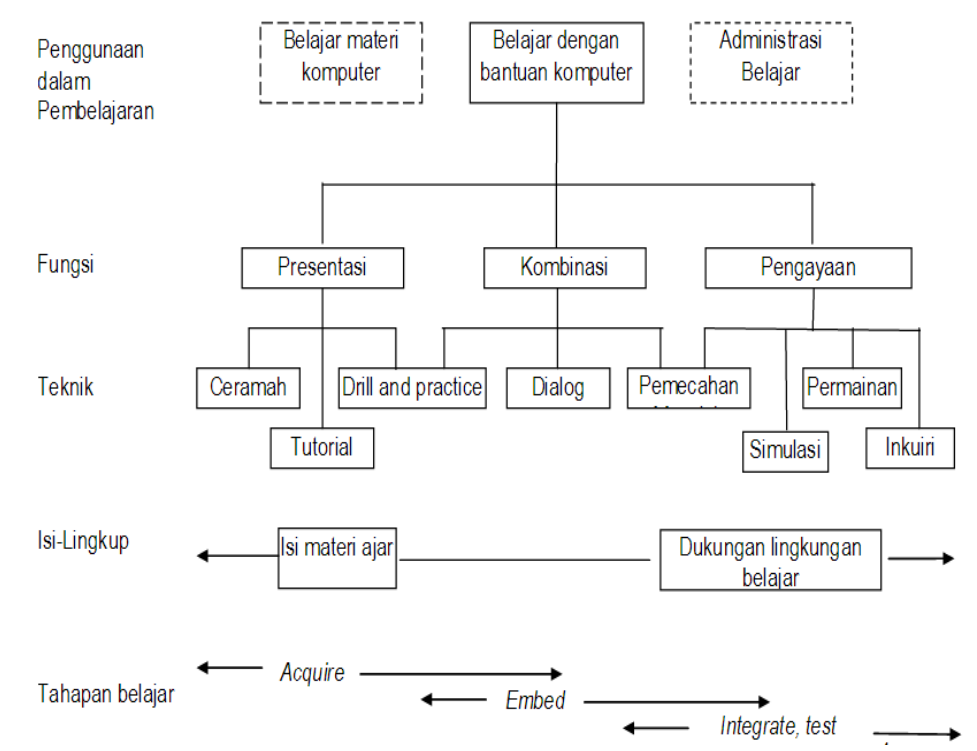

\section{Gambar 18. Taksonomi komputer dalam pendidikan}

Taksonomi tersebut digunakan untuk memberi perbedaan yang ekstrim dari materi ajar dan lingkungan belajar. Perbedaan antara komputer untuk presentasi dan komputer untuk pengayaan

secara jelas dipilihkan antara penggunaan komputer untuk mengajarkan isi materi perkuliahan dan

penggunaan komputer untuk mendukung lingkungan mahasiswa beraktivitas belajar. Pembelajaran berbasis komputer ini membuat siswa berinteraksi langsung dengan media pembelajaran, sehingga guru hanya sebagai desainer dan programer dalam pembelajaran tersebut. Siswa juga akan mendapatkan pengetahuan yang siap pakai. Pembelajaran berbasis komputer ini juga menanamkan pada siswa kebisaaan-kebisaaan belajar secara rutin, disiplin, dan mandiri. Konsep pembelajaran berbasis komputer ini adalah 54 | Teknologi, informasi, dan Komunileasi 
penyajian bahan-bahan pembelajaran dan keahlian atau keterampilan dengan unit-unit kecil, sehingga mudah dipahami dan dipelajari. Kontroling dalam pembelajaran ini berada pada siswa itu sendiri. Oleh karena itu, pembelajaran berbasis komputer ini membisaakan siswa untuk belajar mandiri dengan sistem piranti komputer.

Strategi pembelajaran berbasis komputer mengandung arti bagaimana guru merencanakan kegiatan mengajar ( $a$ plan for teaching) sebelum ia melaksanakan tugasnya bersama dengan anak didik. Strategi merupakan pola umum kegiatan yang harus dilakukan seorang guru untuk mencapai tujuan tertentu. Dikatakan pola umum, sebab suatu strategi pada hakekatnya belum mengarah kepada hal-hal yang bersifat praktis, namun masih berupa rencana atau planning holistic.

Pembelajaran berbasis komputer merupakan pembelajaran yang melibatkan peran serta komputer. Pembelajaran merupakan proses alamiah mengkontruksi sesuatu pada alam pikiran manusia, sehingga manusia mendapatkan pengetahuan yang berbeda dengan sebelumnya. Secara alamiah pula pembelajar akan mendapatkan sebuah pengalaman baru. Manusia pada umumnya telah melakukan kegiatan belajar secara terus menerus dengan melibatkan peran serta perangkat apapun.

Dari defenisi tersebut di atas dapat disimpulkan, bahwa 'strategi' adalah suatu proses penentuan rencana (planning) yang bersifat incremental (senantiasa meningkat) dan secara terus-menerus berfokus untuk mencapai tujuan. Strategi pengajaran oleg seorang guru/pendidik selalu dimulai dari apa yang dapat atau sedang terjadi dan bukan dimulai dari apa yang sudah terjadi. Strategi pembelajaran 55 | Teknologi, informasi, dan Komunikasi 
yang dapat diimplementasikan seorang pendidik terbagi menjadi lima bagian, diantaranya sebagai berikut.

1. Karakteristik strategi pembelajaran langsung (direct instruction)

a) Strategi pembelajaran langsung merupakan strategi yang berpusat pada guru dan strategi ini yang paling sering digunakan guru di kelas. Strategi ini termasuk didalamnya metode- metode ceramah, pertanyaan didaktik, pengajaran eksplisit, praktek dan latihan, serta demonstrasi.

b) Strategi pembelajaran efektif digunakan untuk memperluas informasi atau mengembangkan keterampilan langkah demi langkah, step by step, dll.

2. Karakteristik strategi tidak langsung (indirect instruction);

a) Pembelajaran tidak langsung memperlihatkan bentuk keterlibatan tinggi siswa dalam melakukan observasi, penyelidikan, penggambaran inferensi berdasarkan data, atau pembentukan hipotesis.

b) Dalam pembeljaran tidak langsung, peran guru beralih dari penceramah menjadi fasilitator, pendukung, dan sumber personal (resource person).

c) Guru merancang lingkungan belajar, memberikan kesempatan siswa untuk terlibat, dan jika memungkinkan memberikan umpan balik kepada siswa ketika mereka melakukan inkuiri.

d) Streategi pembelajaran tidak langsung mensyaratkan digunakannya bahan - bahan cetak, non-cetak, dan sumber-sumber manusia.

3. Strategi Pembelajaran Interaktif (Interactive Instruction)

56 | Teknologi, Informasi, dan Komunikasi 
a) Strategi pembelajaran interaktif merujuk kepada bentuk diskusi dan saling berbagi di antara pesrta didik.

b) Seaman dan Fellenz (1989) mengemukakan bahwa diskusi dan saling berbagi akan memberikan kesempatan kepada siswa untuk menerikan reaksi terhadap gagasan, pengalaman, pandangan, dan pengetahuan guru atau kelompok, serta mencoba mencari alternatif dalam berfikir.

c) Strategi pembelajaran interaktif dikembangkan dalam rentang pengelompokkan dan metode - metode interaktif.

d) Di dalamnya terdapat bentuk - bentuk diskusi kelas, dikusi kelompok kecil atau pengerjaan tugas berkelompok, dan kerjasama siswa secara berpasangan.

4. Strategi Belajar Melalui Pengalaman (experiental learning)

a) Strategi belajar melalui pengalaman menggunakan bentuk sekuen induktif, baerpusat pada siswa, dan berorientasi pada aktivitas.

b) Penekanan dalam strategi belajar melalui pengalaman adalah pada saat dalam proses belajar, dan bukan pada hasil belajar peserta didik.

c) Guru dapat menggunakan ini baik di dalam kelas maupun di luar kelas. Sebagai contoh, di dalam kelas digunakan metode simulasi, sedangkan di luar kelas 
dapat dikembangkan metode observasi untuk menperoleh gambaran pendapat umum.

5. Strategi Belajar Mandiri (Independent Study)

a) Strategi belajar mandiri merujuk kepada penggunaan metode pembelajaran yang tujuannya untuk mempercepat pengembangan inisiatif individu, percaya diri, dan perbaikan diri. Fokus strategi belajar mandiri ini adalah merencanakan belajar mandiri siswa di bawah bimbingan atau supervisi guru.

b) Belajar mandiri menuntut siswa untuk bertanggung jawab dalam merencanakan dan menentukan kecepatan belajarnya.

Rendahnya tingkat pemanfaatan TIK di sekolah selama ini disebabkan karena tidak semua sekolah mempunyai kelengkapan sarana TIK dan tidak semua sekolah menggunakan media pembelajaran berbasis radio streaming dan kalaupun ada penggunaannya juga masih jauh dari ukuran optimal (utilitas rendah). TIK telah berkembang seiring dengan globalisasi sehingga interaksi dan penyampaian informasi secara cepat. Dampak dari globalisasi tersebut membawa berdampak positif dan negatif pada suatu negara. Teknologi informasi saat ini telah memutuskan faktor jarak dalam berkomunikasi, hal ini dapat dilihat dengan adanya internet yang setiap saat, kapan dan dimana saja dapat mengakses informasi dari belahan dunia manapun. Dengan adanya globalisasi yang tidak terelakkan ini, mau tidak mau menimbulkan persaingan antar bangsa sehingga menuntut adanya pengembangan kualitas sumber daya manusia. Pendidikan adalah salah satu hal penting dalam pengembangan sumber daya manusia.

58 | Teknologi, informasi, dan Komunikasi 


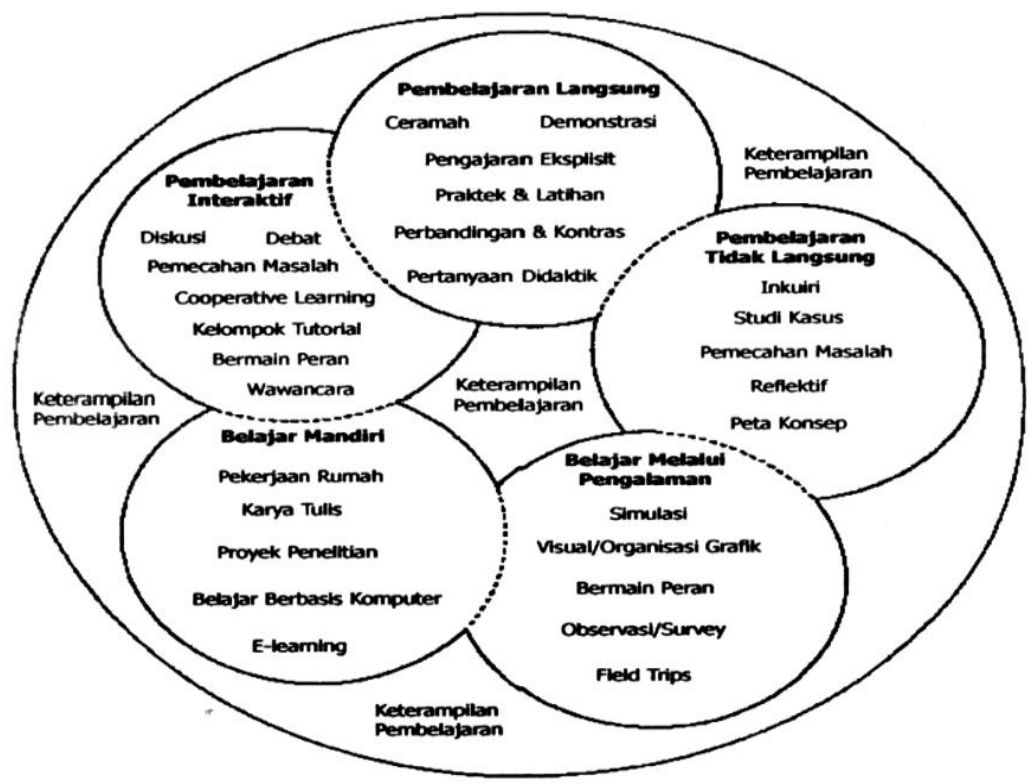

Gambar 19. Strategi pembelajaran peserta didik

\section{Pemanfaatan Microsoft Power Point untuk Pembelajaran}

E-Learning merupakan media dan proses pendidikan yang memanfaatkan perkembangan teknologi elektronika saat ini. Dalam konteks ini yang dimaksud dengan elektronik adalah teknologi komputer yang dikaitkan dengan penggunann internet. Dalam pelatihan tersebut, para peserta dilatih bagaimana cara menggunakan berbagai program aplikasi, baik yang berbasis pengolah kata (microsoft word), program aplikasi berbasis angka (microsoft excel), program aplikasi berbasis data (microsoft acces), program aplikasi berbasis multi media (power point), dan pembuatan situs Blog. Contoh nyata dari pemanfaatan perkembangan 59 | Teknologi, Informasi, dan Komunikasi 
teknologi ini adalah dengan pembuatan media pembelajaran yang memanfaatkan program aplikasi microsoft power point. Program ini memiliki kemampuan yang sangat baik dalam menyajikan sebuah materi presentasi, dan sudah banyak digunakan dalam dunia pendidikan.

Namun, dengan gaya penyajian yang 'berbeda', dengan memanfaatkan berbagai fasilitas yang ada di Ms Powerpoint, ditambah dengan sedikit sentuhan kreatifitas yang unik, akan membuat media presentasi yang biasa, menjadi luar biasa. Untuk mewujudkan suasana kelas yang kreatif dan inspiratif, tentu tidak bisa hanya melalui sebuah media ajar. Akan tetapi, kombinasi antara model pembelajaran dan media ajar berbasis teknologi informasi dan komunikasi yang mendukung keterlibatan (interaksi) antara siswa dan guru, akan membuat kelas menjadi "hidup“. Mengoptimalkan microsoft power point sebagai media belajar berarti memanfaatkan secara maksimal segala fitur untuk menunjang kegiatan belajar mengajar. Microsoft power point merupakan sebuah software yang dibuat dan dikembangkan oleh perusahaan Microsoft berbasis multi media. Aplikasi software microsoft power point yang digunakan untuk presentasi memanfaatkan berbagai fasilitas seperti hyperlink, insert picture, table, grafik movie, sound beserta efek animasinya (custom animation) dalam menampilkan gambar bangun, garis, teks dan gambar secara kolaboratif. Pada mata kuliah teknologi informasi dan komunikasi guna mempersiapkan mahasiswa mengantisipasi pesatnya perkembangan agar mereka memiliki bekal untuk menyesuaikan diri dalam kehidupan global yang ditandai dengan perubahan yang sangat cepat. Untuk

60 | Teknologi, Informasi, dan Komunikasí 
menghadapi perubahan tersebut diperlukan kemampuan dan kemauan untuk belajar sepanjang hayat.

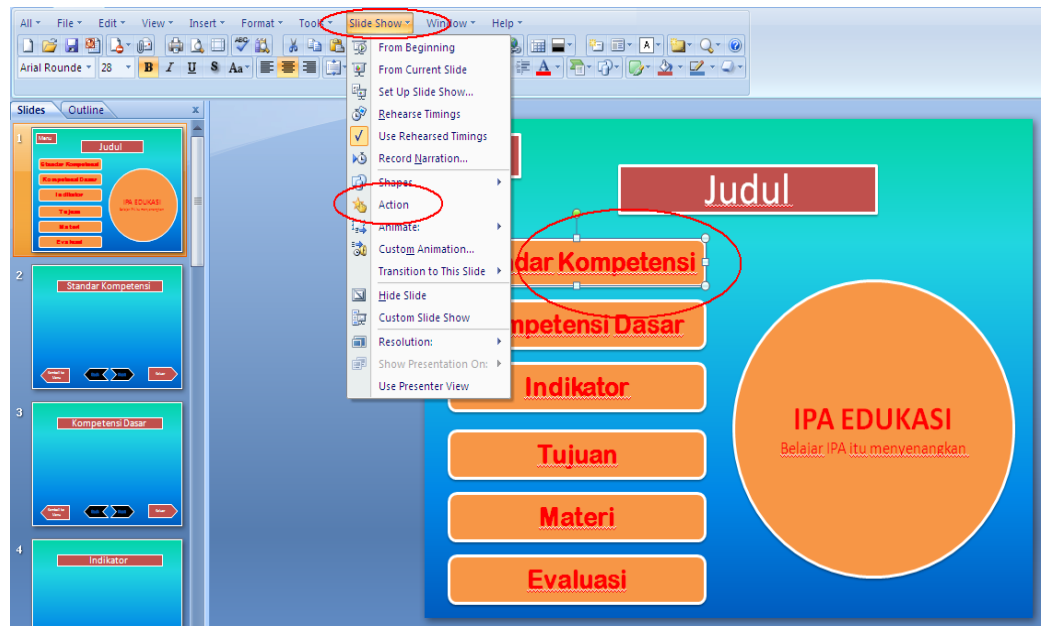

Gambar 20. Microsoft Power Point

Microsoft power point adalah program aplikasi untuk membuat atau mengolah data presentasi. Data presentasi yang dibuat dapat berupa teks, tabel, grafik, gambar, bagan organisasi, dan sebagainya. (Gumawang, 2007). Menurut Alfian (2010). Power point merupakan salah satu sarana yang populer karena kemudahan dan kelengkapan fitur-fiturnya sangat mendukung dalam pembuatan sebuah presentasi yang baik. Dengan program ini, dapat menjelaskan ide atau gagasan kepada orang lain seperti guru, teman-teman, atau orang tua secara efektif sehingga materi yang kita sampaikan akan lebih jelas, menarik, mudah dipahami dan praktis.

61 | Teknologi, Informasi, dan Komunikasi 
Karena program ini dapat memberikan gambar dan warna yang menarik pada lembar presentasi, serta penyusunnya dengan rapi.

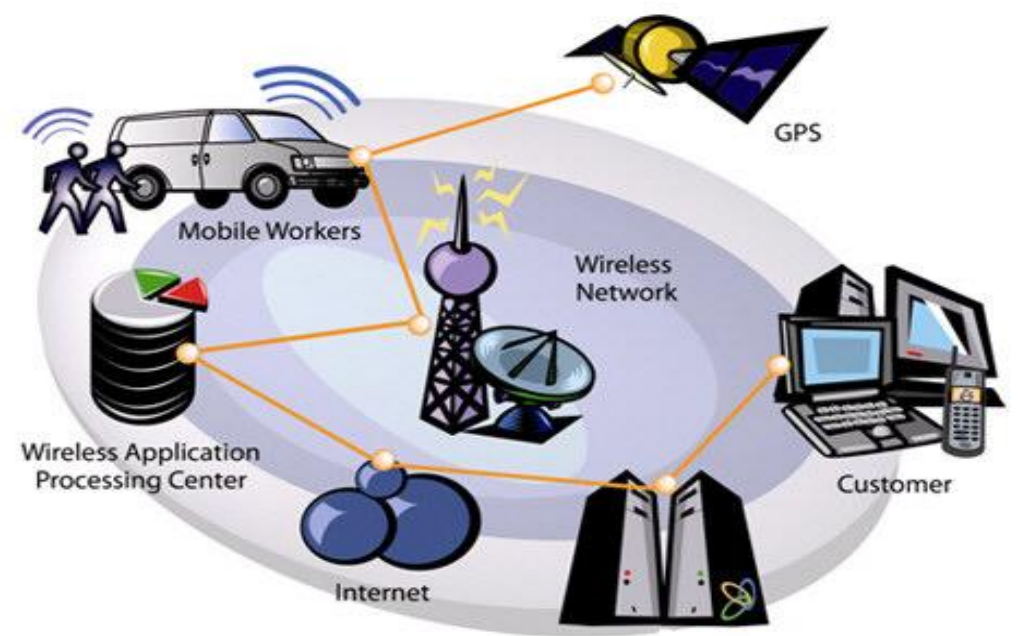

\section{Gambar 21. Perkembangan teknologi dalam aspek kehidupan}

Teknologi informasi dan komunikasi berkembang dengan pesatnya dipicu oleh temuan dalam bidang rekayasa material mikro elektronika. Perkembangan ini berpengaruh besar terhadap berbagai aspek kehidupan, bahkan perilaku dan aktifitas manusia kini banyak tergantung kepada pemanfaatan rekayasa teknologi informasi dan komunikasi. Hasil perkembangan teknologi informasi dan komunikasi telah banyak membantu manusia dalam segala aspek kehidupannya. Dengan demikian, teknologi informasi dan komunikasi dapat dimanfaatkan untuk merevitalisasi proses

62 | Teknologi, Informasi, dan Komunikasi 
belajar yang pada akhirnya dapat mengadaptasikan peserta didik dengan lingkungan dan dunia kerja.

Contoh nyata dari pemanfaatan perkembangan teknologi pendidikan ini adalah dengan pembuatan media pembelajaran yang memanfaatkan program aplikasi microsoft power point. Program ini memiliki kemampuan yang sangat baik dalam menyajikan sebuah materi presentasi, dan sudah digunakan dalam dunia pendidikan dan menjadi sebuah hal yang cukup menarik perhatian. Presentasi Power Point adalah bentuk yang paling sederhana dan paling mudah dan paling praktis sehingga paling banyak dipergunakan oleh kebanyakan pembicara, baik pembicara seminar, workshop, dan juga guru di kelas. Hendaknya, setiap guru paling tidak mempunyai kemampuan untuk membuat materi ajar dalam bentuk presentasi power point.

\section{Inovasi Teknologi Informasi dan Komunikasi}

Seperti yang telah dibahas sebelumnya, perkembangan teknologi informasi dewasa ini telah berimbas pada dunia pendidikan, dengan di tandai oleh munculnya berbagai inovasi dan kreasi dalam proses penyampaian bahan ajar kepada peserta didik. Sebagaimana kita ketahui, bahwa dalam proses pendidikan terdapat 3 proses inti pendidikan (core processes), yaitu; pengajaran (teaching), penelitian (research), dan pelayanan (services), dimana ketiganya menjadi sumber akses bagi penggunaan dan pemanfaatan teknologi informasi. Hal ini sebagaimana firman Allah dalam Q.S Al-Ghaasysiah (17-20)

63 | Teknologi, Informasi, dan Komunikasi 


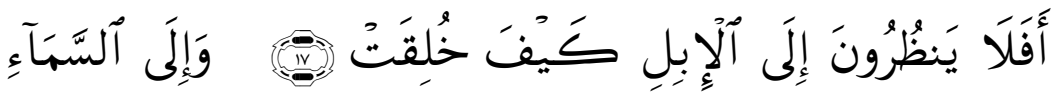

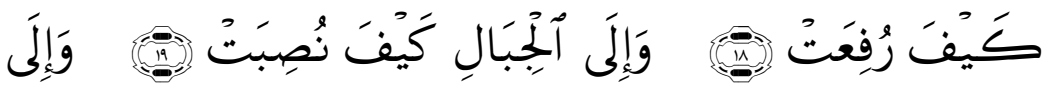

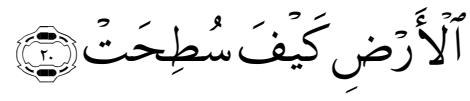

" Maka Apakah mereka tidak memperhatikan unta bagaimana Dia diciptakan? dan langit, bagaimana ia ditinggikan? dan gunung-gunung bagaimana ia ditegakkan? dan bumi bagaimana ia dihamparkan?"

Ada beberapa konsep yang melatar belakangi penggunaan teknologi informasi untuk pendidikan, dan beberapa diantara sudah banyak diterapkan di lembaga pendidikan baik tingkat dasar maupun tingkat menengah, apalagi di perguruan tinggi. Penggunaan teknologi telah berdampak langsung dan tidak langsung terhadap penyelenggaraan pendidikan yang mengarah pada peningkatan mutu sumber daya manusia. Konsep-konsep tersebut diantaranya adalah penggunaan teknologi untuk membantu tenaga pendidik dalam penyelenggaraan proses pembelajaran, terutama digunakan sebagai alat penggambaran / ilustrasi dari pelajaran yang sedang diajarkan sehingga peserta didik memperoleh gambaran jelas berkaitan antara teori dengan gambaran nyatanya.

64 | Teknologi, Informasi, dan Komunikasi 


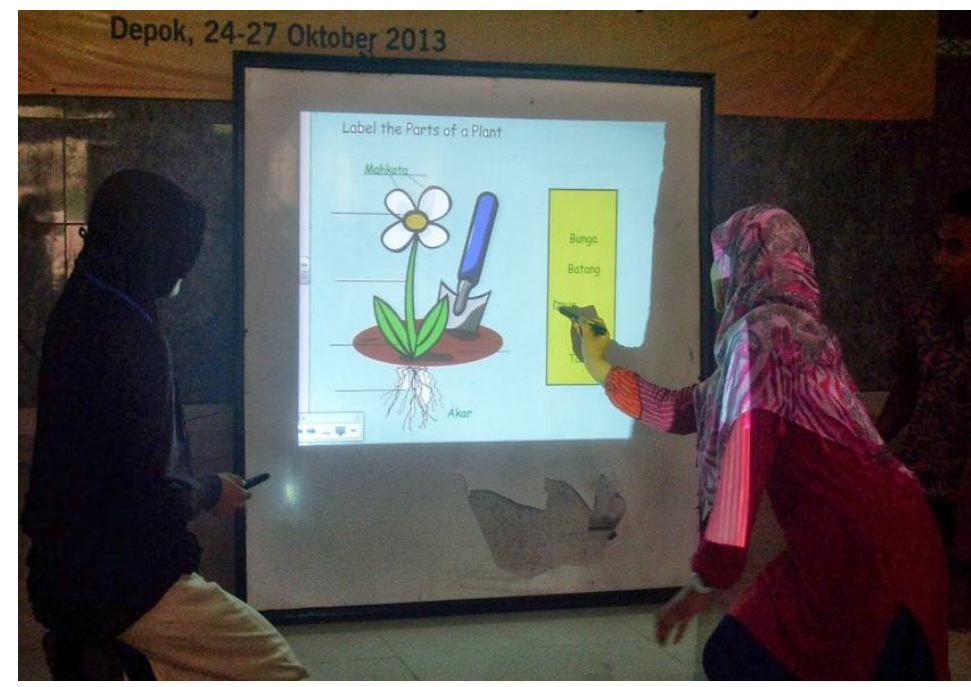

\section{Gambar 22. Pembelajaran dengan power point}

Menurut Kemp (1975), karakteristik sebuah media pembelajaran merupakan dasar pemilihan media sesuai dengan situasi belajar tertentu. Dia juga mengatakan, bahwa pengetahuan mengenai kekurangan dan kelebihan tertentu yang dimiliki oleh sebuah media pembelajaran, adalah sesuatu yang sangat penting diketahui oleh para tenaga pendidik. Pendapat lain mengenai prosedur pemilikan media komunikasi, dikemukakan oleh Anderson (2002). Menurutnya, prosedur pemilihan media dimulai dari pertanyaan; Apakah media tersebut diperuntuhkan bagi keterampikan fisik atau kognitif. Pertanyaan ini akan menentukan desain seperti apa media pembelajaran tersebut seharusnya dibuat. Jika kita mengacu pada hasil penelitian tersebut, maka penggunaan program microsoft power point 65 | Telenologi, Informasi, dan Komunikasí 
ini akan sangat berdampak pada tujuan pembelajaran yang menentukan pengenalan visual dan prinsip bahan ajar yang diberikan oleh tenaga pendidiknya. Microsoft power point merupakan sebuah sofware yang dibuat dan dikembangkan oleh perusahaan Microsoft, dan merupakan salah satu program berbasis multi media. Program ini dirancang khusus untuk menyampaikan presentasi dengan berbagai fitur menu yang mampu menjadikanya sebagai media komunikasi yang menarik. Beberapa hal yang menjadikan media ini menarik untuk digunakan sebagai alat presentasi adalah berbagai kemampuan pengelolahan teks, warna, gambar, serta animasianimasi yang bisa diolah sendiri sesuai kreatifitas penggunanya.

Pada prinsipnya program ini terdiri dari beberapa unsur rupa, dan pengontrolan operasionalnya. Unsur rupa yang dimaksud, terdiri dari slide, teks, gambar dan bidang-bidang warna yang dapat dikombinasikan dengan latar belakang yang telah tersedia. Unsur rupa tersebut dapat kita buat tanpa gerak, atau dengan gerakan tertentu sesuai keinginan kita. Seluruh tampilan dari program ini dapat kita atur sesuai keperluan, apakah akan berjalan sendiri seuai timing yang kita inginkan, atau berjalan secara manual, yaitu dengan mengklik tombol mouse. Biasanya jika digunakan untuk penyampaian bahan ajar yang mementingkan terjadinya interaksi antara peserta didik dengan tenaga pendidik, maka kontrol operasinya menggunakan cara manual. Selain itu,agar proses belajar menjadi lebih interaktif, e-learning for kids salah satu alternatif penggunaan media yang mampu memfasilitasi siswanya dengan permainan games- games

66 | Teknologi, Informasi, dan Komunileasi 
edukatif sehingga anak lebih terdorong untuk aktif dalam pembelajaran.

67 |Teknologi, Informasi, dan Komunikasi 


\section{Rangkuman dan Soal}

1. Aplikasi komputer dalam bidang pembelajaran memungkinkan berlangsungnya proses belajar secara individual (individual learning). Pemakai komputer atau user dapat melakukan interaksi langsung dengan sumber informasi. Perkembangan teknologi komputer jaringan (computer network/Internert) saat ini telah memungkinkan pemakainya melakukan interaksi dalam memperoleh pengetahuan dan informasi yang diinginkan. Berbagai bentuk interaksi pembelajaran dapat berlangsung dengan tersedianya medium komputer dalam memberikan umpan balik (feedback) yang segera kepada pemakainya

2. Strategi pembelajaran berbasis komputer mengandung arti bagaimana guru merencanakan kegiatan mengajar ( $a$ plan for teaching) sebelum ia melaksanakan tugasnya bersama dengan anak didik. Strategi merupakan pola umum kegiatan yang harus dilakukan seorang guru untuk mencapai tujuan tertentu. Dikatakan pola umum, sebab suatu strategi pada hakekatnya belum mengarah kepada hal-hal yang bersifat praktis, namun masih berupa rencana atau planning holistic.

3. Microsoft power point merupakan sebuah sofware yang dibuat dan dikembangkan oleh perusahaan Microsoft, dan merupakan salah satu program berbasis multi media. Program ini dirancang khusus untuk menyampaikan presentasi dengan berbagai fitur menu yang mampu menjadikanya sebagai media komunikasi yang menarik.

68 | Teknologi, Informasi, dan Komunikasí 
Beberapa hal yang menjadikan media ini menarik untuk digunakan sebagai alat presentasi adalah berbagai kemampuan pengelolahan teks, warna, gambar, serta animasi-animasi yang bisa diolah sendiri sesuai kreatifitas penggunanya.

4. E-Learning merupakan media dan proses pendidikan yang memanfaatkan perkembangan teknologi elektronika saat ini. Dalam konteks ini yang dimaksud dengan elektronik adalah teknologi komputer yang dikaitkan dengan penggunann internet. Dalam pelatihan tersebut, para peserta dilatih bagaimana cara menggunakan berbagai program aplikasi, baik yang berbasis pengolah kata (microsoft word), program aplikasi berbasis angka (microsoft excel), program aplikasi berbasis data (microsoft acces), program aplikasi berbasis multi media (power point), dan pembuatan situs Blog.

\section{Latihan Soal}

1. Jelaskan sistem aplikasi komputer dalam bidang pembelajaran memungkinkan berlangsungnya proses belajar secara individual (individual learning) sehingga dapat memberikan umpan balik (feedback) yang segera kepada penggunanya?

2. Jelaskan bagaimana strategi pembelajaran berbasis komputer yang biasa di sebut a plan for teaching yang harus dilakukan seorang guru untuk mencapai tujuan pembelajaran?

69 | Teknologi, Informasi, dan Komunikasi 
3. Jelaskan makna dari planning holistic kaitannya dalam pembelajaran berbasis komputer?.

4. Jelaskan perbedaan dari microsoft power point dan eLearning kaiitannya dalam perkembangan teknologi elektronika saat ini?

70 | Teknologi, Informasi, dan Komunikasi 


\section{BAB V \\ Media Pembelajaran Berbasis E-Learning}

Bab ini membahas tentang penerapan model pembelajaran yang dapat berkesinambungan dan memberikan pengaruh positif dalam pelaksanaannya. Berkaitan dengan pembelajaran, pemanfaatan teknologi informasi dalam hal ini e-learning diperlukan tidak hanya pendidik yang terampil memanfaatkan teknologi serta teknologi untuk pembuatan bahan ajar, akan tetapi diperlukan suatu rancangan agar dapat melaksanakan pembelajaran dengan efektif.

Dalam sebuah rancangan pembelajaran terdapat suatu proses untuk memandu pelaku untuk mendesain, mengembangkan, menerapkan konten e-learning dengan memanfaatkan infrastruktur dan aplikasi e-learning yang tersedia. Pada tahap selanjutnya dalam implementasi $e$ learning terdapat tahap evaluasi yang dimanfaatkan untuk merevisi atau penyesuaian terhadap tahap-tahap sebelumnya. Desain instruksional merupakan proses dinamis yang dapat berubah-ubah sesuai dengan informasi dan evaluasi yang diterima bertujuan untuk meningkatkan hasil pembelajaran peserta didik sehingga tujuan pembelajaran dapat tercapai.

Bab ini selanjutnya akan membahas lebih detail tentang media pembelajaran berbasis e-learning, diantaranya meliputi.

1. Pemanfaatan Media E-Learning

2. Teknologi Penunjang E-Learning

3. Pengajaran Berbasis Web

4. IT Pembelajaran Berbasis Multimedia

71 | Teknologi, Informasi, dan Komunikasí 


\section{A. Pemanfaatan Media E-learning}

E-Learning adalah sistem pembelajaran yang memanfaatkan media elektronik sebagai alat untuk membantu kegiatan pembelajaran. Sebagian besar beransumsi bahwa elektronik yang dimaksud disini lebih diarahkan pada penggunaan teknologi komputer dan internet. Melalui komputer, siswa dapat belajar secara individual baik secara terprogram maupun tidak terprogram. Secara tidak terprogram siswa dapat mengakses berbagai bahan belajar dan informasi di internet menggunakan fasilitas di internet seperti mesin percari data (search enggine). Secara bebas siswa dapat mencari bahan dan infomasi sesuai dengan minat masing - masing tanpa adanya intervensi dari siapapun. Sebagian user komputer juga sering dimanfaatkan untuk hiburan seperti bermain game, namun demikian hal tersebut tidak dapat dihindari sebab penggunaan media elektronik terutama internet bebas digunakan.

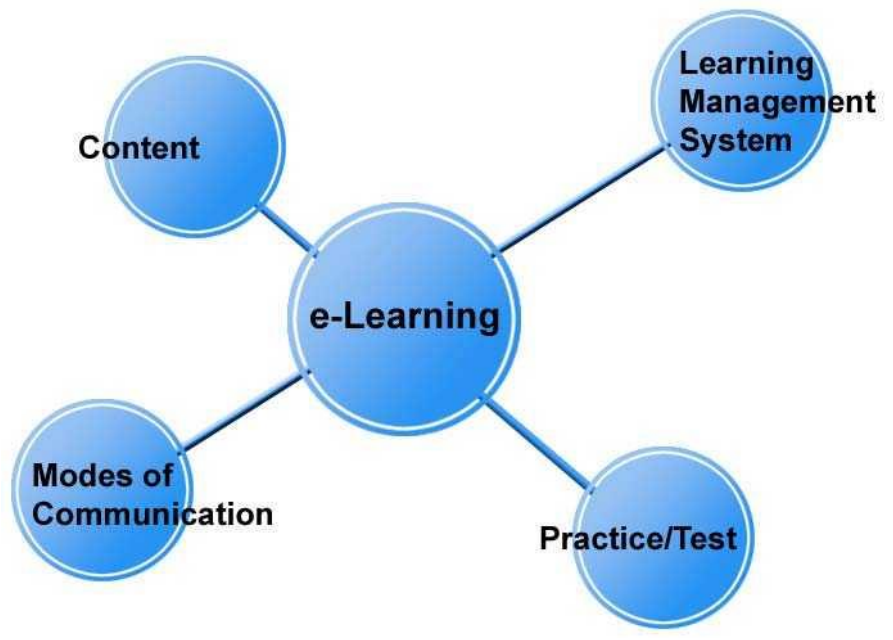

Gambar 23. Komponen e-learning

72 | Teknologi, Informasi, dan Komunikasi 
Internet juga dapat digunakan secara terprogram, salah satunya dengan program e-learning. Pada programini sekolah atau pihak penyelenggara menyediakan sebuah situs / web elearning yang menyediakan bahan belajar secara lengkap baik yang bersifat interaktif maupun non interaktif. Kegiatan siswa dalam mangaskses bahan belajar melalui e-learning dapat dideteksi dari apa yang mereka pelajari, bagaimana prosesnya, bagaimana kemajuan belajarnya, berapa skor hasil belajarnya dan lain sebagainya. Di indonesia pada umumnya masih bersifat blendded e-learning, yaitu e-learning bukan alat pelengkap dari pembelajaran konvensional. Perkembanagn teknologi komunikasi dan informasi telah membuka kemungkinan yang luas untuk dapat dimanfaatkan dalam bidang pendidikan. Hal ini disebabkan pesatnya teknologi komunikasi dan informasi yang sudah menjadi bagian dari kebudayaan masyarakat Indonesia.

Dalam prakteknya e-learning memerlukan bantuan teknologi. Karena itu dikenal istilah: computer based learning (CBL) yaitu pembelajaran yang sepenuhnya menggunakan komputer; dan computer assisted learning (CAL) yaitu pembelajaran yang menggunakan alat bantu utama komputer. Teknologi pembelajaran terus berkembang. Namun pada prinsipnya teknologi tersebut dapat dikelompokkan menjadi dua, yaitu: technology based learning dan technology based web-learning. Technology based learning ini pada prinsipnya terdiri dari audio information technologies dan video information technologies. Sedangkan technology based web-learning pada dasarnya adalah data information technologies.

73 | Teknologi, Informasi, dan Komunikasi 


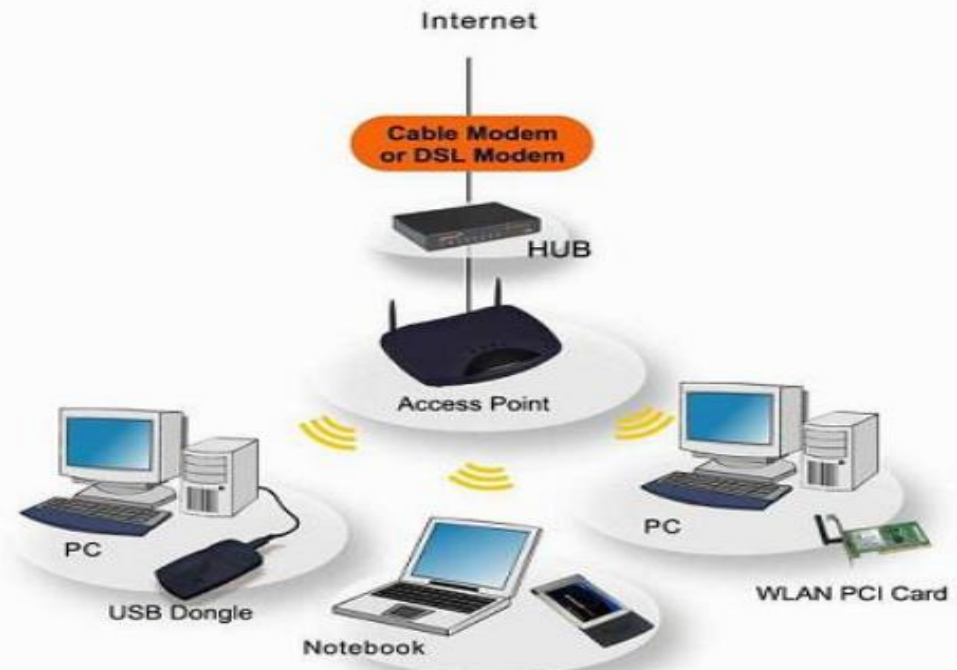

WLAN PC Card

\section{Gambar 24. Jaringan internet yang dapat diakses untuk pembelajaran}

Media yang diharapkan menjadi bagian dari suatu proses belajar mengajar di sekolah berupa internet harus mampu memberikan dukungan bagi terselenggaranya proses komunikasi interaktif antara guru dengan siswa sebagaimana yang dipersyaratkan dalam suatu kegiatan pembelajaran. Kondisi yang harus mampu didukung oleh internet tersebut terutama berkaitan dengan strategi pembelajaran yang akan dikembangkan, yang kalau dijabarkan secara sederhana, bisa diartikan sebagai kegiatan komunikasi yang dilakukan untuk mengajak siswa mengerjakan tugas-tugas dan membantu siswa dalam memeperoleh pengetahuan yang dibutuhkan dalam rangka mengerjakan tugas-tugas tersebut. Strategi pembelajaran yang meliputi pengajaran, diskusi, membaca, penugasan, presentasi dan evaluasi (Boettcher 1999).

74 |Teknologi, informasi, dan Komunikasi 


\section{B. Teknologi Penunjang E-learning}

E-learning merupakan salah satu bentuk model pembelajaran yang difasilitasi dan didukung pemanfaatan teknologi informasi dan komunikasi. E-learning mempunyai ciri-ciri, antara lain ( Mayer, 2008) menyebutkan beberapa hal, diantaranya 1) memiliki konten yang relevan dengan tujuan pembelajaran; 2) menggunakan metode instruksional, misalnya penyajian contoh dan latihan untuk meningkatkan pembelajaran; 3) menggunakan elemen-elemen media seperti kata-kata dan gambar-gambar untuk menyampaikan materi pembelajaran; 4) memungkinkan pembelajaran langsung berpusat pada pengajar (synchronous elearning) atau di desain untuk pembelajaran mandiri (asynchronous elearning); 5) membangun pemahaman dan ketrampilan yang terkait dengan tujuan pembelajaran baik secara perseorangan atau meningkatkan kinerja pembelajaran kelompok.

Sedangkan menurut Rusman dkk (2011) e-learning memiliki karakteristik, antara lain (a) interactivity (interaktivitas); (b) independency (kemandirian); (c) accessibility (aksesibilitas); (d) enrichment (pengayaan). Elearning merupakan singkatan dari Elektronic Learning, merupakan cara baru dalam proses belajar mengajar yang menggunakan media elektronik khususnya internet sebagai sistem pembelajarannya. E-learning merupakan dasar dan konsekuensi logis dari perkembangan teknologi informasi dan komunikasi. E-learning bisa juga dilakukan secara informal dengan interaksi yang lebih sederhana, misalnya melalui sarana mailing list, e-newsletter atau website pribadi, organisasi dan perusahaan yang ingin mensosialisasikan jasa,

75 | Teknologi, informasi, dan Komunikasi 
program, pengetahuan atau keterampilan tertentu pada masyarakat luas.

E-learning merupakan sebuah bentuk kemajuan teknologi informasi yang diterapkan di bidang pendidikan. Istilah e-learning lebih tepat ditujukan sebagai bentuk usaha untuk membuat sebuah transformasi proses pembelajaran yang ada di sekolah atau perguruan tinggi ke dalam bentuk digital yang dijembatani teknologi internet. Pembelajaran berbasis teknologi informasi dan komunikasi akan berjalan efektif jika peran pengajar dalam pembelajaran adalah sebagai fasilitator pembelajaran atau memberikan kemudahan pembelajar untuk belajar bukan hanya sebagai pemberi informasi. Proses pembelajaran dengan memanfaatkan teknologi informasi dan komunikasi merupakan bimbingan dari pengajar untuk memfasilitasi pembelajaran pembelajar yang efektif (Munir, 2009).
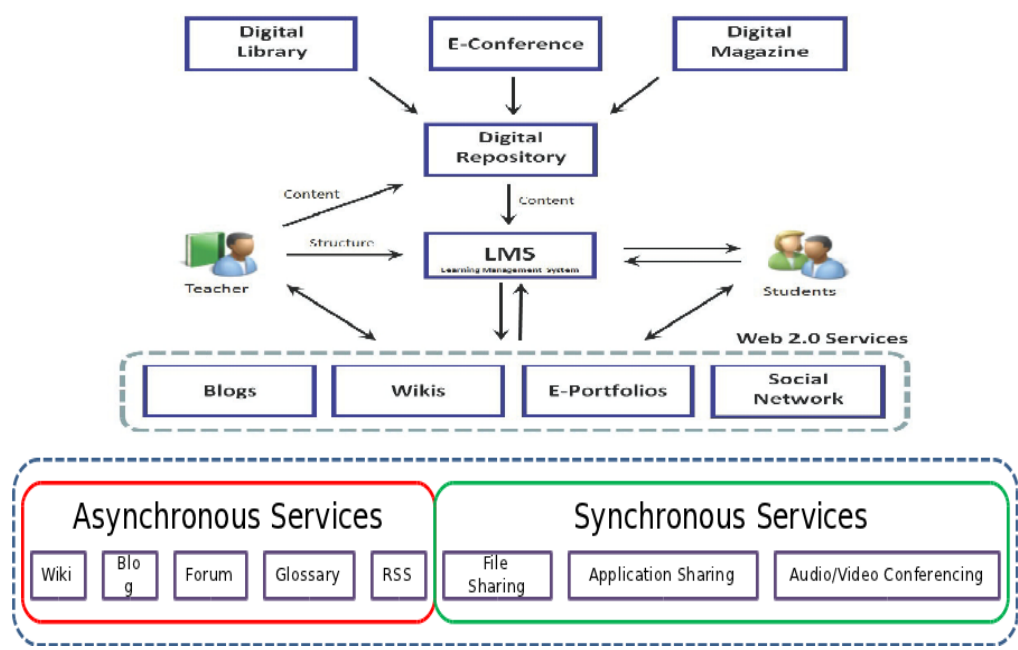

Gambar 25. Karakteristik Pemanfaatan E-learning

76 | Teknologi, informasi, dan Komunikasi 
Dalam pelaksanaan pembelajaran sehari-hari, yang sering dijumpai adalah kombinasi dari teknologi yang dituliskan di atas (audio/data, video/data, audio/video). Teknologi ini juga sering di

pakai pada pendidikan jarak jauh (distance education), dimasudkan agar komunikasi antara peserta didik dan guru bisa terjadi dengan keunggulan teknologi e-learning ini. Menurut Onno W. Purbo (1997), "ada lima aplikasi standar internet yang dapat digunakan untuk keperluan pendidikan, yaitu email, mailing list (milis), news group, dan world wide web (WWW).

Rosenberg (2001) mengkatagorikan tiga kriteria dasar yang ada dalam e-learning. Pertama, e-learning bersifat jaringan, yang membuatnya mampu memperbaiki secara cepat, menyimpan atau memunculkan kembali, mendistribusikan, dan sharing pembelajaran dan informasi. Kedua, e-learning dikirimkan kepada pengguna melalui komputer dengan menggunakan standar teknologi internet. Ketiga, e-learning terfokus pada pandangan pembelajaran yang paling luas, solusi pembelajaran yang menggungguli paradigma tradisional dalam pelatihan.

Dengan demikian karakteristik e-learning dapat disimpulkan, antara lain 1) dapat digunakan sebagai jasa teknologi, di mana guru dan siswa, siswa dan sesama siswa atau guru dan sesama guru dapat berkomunikasi dengan relatif mudah dengan tanpa dibatasi jarak dan tempat; 2) memanfaatkan keunggulan komputer (digital media dan computer networks); 3) menggunakan bahan ajar bersifat mandiri (self learning materials) yang dapat disimpan di komputer sehingga dapat diakses oleh guru dan siswa kapan 77 | Teknologi, informasi, dan Komunikasi 
saja dan di mana saja bila yang bersangkutan memerlukannya; 4) memanfaatkan jadwal pembelajaran, kurikulum, hasil kemajuan belajar dan hal-hal yang berkaitan dengan administrasi pendidikan dapat dilihat setiap saat di komputer.

Pembelajaran yang efektif adalah yang memanfaatkan teknologi informasi dan komunikasi secara optimal dalam proses pembelajarannya sebagai alat bantu. Salah satu pemanfaatan teknologi informasi dan komunikasi dalam pembelajaran adalah dengan memanfaatkan e-learning. Dengan demikian pendayagunaan ICT untuk pendidikan menjadi demikian penting, baik dalam rangka penyiapan tenaga ICT yang andal maupun mendukung proses pembelajaran tatap muka atau jarak jauh. Upaya tersebut diharapkan akan mampu menutup jurang kesenjangan digital, yang pada gilirannya diharapkan akan mampu meningkatkan daya saing bangsa dalam rangka meningkatkan perekonomian negara dan SDM yang handal. Contoh kongkrit dalam pendayagunaan ICT adalah proses belajar dikelas yang menggunakan internet sebagai media pembelajaran sebagai media yang diharakan akan menjadi bagian suatu proses belajar di sekolah, internet diharapkan mampu memberikan dukungan bagi terselenggaranya proses komunikasi interaktif antar guru dengan siswa. Kondisi yang perlu didukung oleh internet berkaitan dengan strategi pembelajaran yang akan dikembangkan, yaitu sebagai kegiatan komunikasi yang dilakukakan untuk mengajak siswa mengerjakan tugas-tugas dan membantu siswa dalam memperoleh pengetahuan yang dibutuhkan dalam rangka mengerjakan tugas-tugas tersebut. (Boettcher 1999).

78 | Teknologi, Informasi, dan Komunikasi 
Ironisnya, guru masih sedikit sekali menggunakan media internet ini sebagai media pembelajaran, kemungkinan disebabkan kurang pahamnya guru mengoperasikan komputer, sehingga timbul rasa keminderan dalam diri seorang guru untuk mengajak siswanya belajar dengan menggunakan media internet, padahal mau tidak mau kita tidak munkin terhindar dari teknologi komunikasi dan informasi. Banyak hal yang dapat dilakukan seorang guru agar mampu menyesuaikan diri dalam era pembelajaran yang semakin canggih, terutama manggunakan media internet. Kompetensi guru harus lebih ditingkatkan, misal dengan mengikuti pelatihan yang berbasis komputer, kursus-kursus, dan sekolah agar lebih tanggap untuk mengirim guru gurunya mengikuti pelatihan - pelatihan, baik yang diselenggarakan oleh dinas pendidikan maupun sekolahsekolah lain, dan memberikan kesempatan yang sama kepada guru -guru untuk dapat lebih aktif dalam mengikuti pelatihan yang berbasis komputer, serta mengadakan pelatihan komputer secara internal dilingkungan sekolah masingmasing. Bila hal itu dapat kita lakukan mudah-mudahan dapat mengurangi jumlah guru yang sangat alergi terhadap komputer dan dapat melakukan proses belajar dikelas dengan menggunakan media internet. Institusi pendidikan yang menyelenggarakan pembelajaran berbasis internet biasanya menggunakan web encaned course, yaitu pemanfaatan internet sebagai penunjang peningkatan kualitas kegiatan belajar mengajar dikelas. Bentuk ini juga dikenal dengan nama web life course, karena kegiatan pembelajaran utama adalah tatap muka dikelas antara guru dengan siswa.

79 | Teknologi, informasi, dan Komunikasi 
Sekolah merupakan sebuah sistem yang tidak dapat dipisahkan antara sub-sistem dengan sub sistem lainnya yaitu meliputi pihak sekolah, pemerintah daerah dan pemerintah pusat, komite sekolah, dan peran masyarakat. Sekolah yang ingin memanfaatkan internet sebagai media embelajaran harus bisa diberi otonomi dan keluwesan-keluwesan yang lebih besar dalam mengelola sumber daya pendidikan di sekolah tersebut. Karena walau bagaimanapun kita tidak bisa terhindar dari globalisasi yang salah satunya adalah meningkatnya pembelajaran teknologi komunikasi dan informasi. Dengan demikian, terlihat bahwa media lain yang selama ini telah dipergunakan sebagai media pendidikan secara luas, internet juga mempuyai peluang yang tak kalah besarnya, dan bahkan mungkin karena keunikanya yang bisa mengakses segala informasi dari penjuru dunia. Internet bisa menjadi media pembelajaran yang paling terkemuka dan dipergunakan secara luas di sekolah-sekolah, terutama sekolah yang berstandar Nasional dan Sekolah Berstandar Internasioanal.

\section{Pengajaran Berbasis Web}

Menurut Clark (1996), WBI adalah pengajaran individual yang dikirim melalui jaringan komputer umum atau pribadi dan ditampilkan oleh web browser. Oleh karena itu kemajuan WBI

akan terkait dengan kemajuan teknologi web (perangkat keras dan perangkat lunak) maupun Pertumbuhan jumlah situs-situs web di dunia yang sangat cepat. Kemajuan perangkat keras ditandai dengan pemakaian teknologi ATM (asynchronous

80 |Teknologi, Informasi, dan Komunikasi 
transfer mode) dan serat optis yang memungkinkan transfer data yang besar dan cepat.

Disamping itu perkembangan WBI juga dipacu oleh besarnya keuntungan yang didapat bila dibanding denganmedia pengajaran lainnya. Pemanfaatan internet dalam WBI ini mampu mendorong perkembangan universitas terbuka atau pembelajaran jarak jauh, karena WBI dianggap paling murah dibanding $\mathrm{CAI} / \mathrm{CBI}$, siaran radio, kaset video, dan lainnya. Dengan WBI ini belajar tidak lagi terikat dengan waktu dan ruang tentunya.

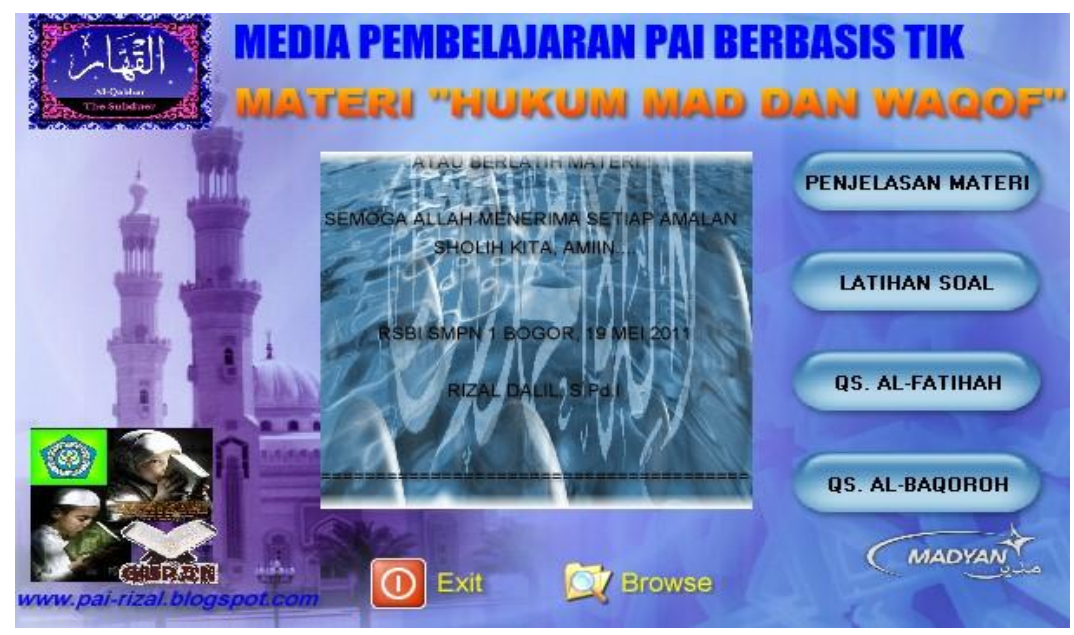

\section{Gambar 26. Pembelajaran Berbasis Web}

Dalam web bisa diperoleh informasi video dan suara sekaligus teks dan gambar serta dimungkinkan komunikasi interaktif dari berbagai sumber informasi di seluruh dunia. Di samping itu, menurut McManus (1995) ternyata jaringan internet bukanlah semata-mata suatu media, tetapi lebih dari

81 | Teknologi, Informasi, dan Komunileasi 
itu juga merupakan pemberi materi dan sekaligus materinya. Seorang dosen yang mengajarkan suatu topik tertentu melalui web akan dengan mudah menghubungkannya dengan situssitus web yang berkaitan dengan topik tersebut. Seperti halnya dalam program belajar jarak-jauh lainnya, tidak ada suatu cara untuk menjamin bahwa orang yang duduk mengerjakan soal-soal di depan komputer yang letaknya jauh di belahan bumi sana adalah mahasiswa yang telah terdaftar. Karena sifat internet yang dapat dihubungi setiap saat, artinya mahasiswa dapat memanfaatkan program-program pendidikan yang disediakan di jaringan internet kapan saja sesuai dengan waktu luang mereka sehingga kendala ruang dan waktu yang mereka hadapi untuk mencari sumbar belajar apat teratasi.

Perkembangan IT bagi dunia pendidikan seharusnya berarti tersedianya saluran atau sarana yang dapat dipakai untuk menyiarkan program pendidikan. Indonesia baru memasuki tahap mempelajari pengembangan dan penerapan IT untuk memasuki milenium ketiga ini. Informasi yang diwakilkan oleh komputer yang terhubung dengan internet sebagai media utamanya telah mampu memberikan kontribusi yang demikian besar bagi bidang pendidikan. Setiap sistem sekolah dikembangkan moderat terhadap teknologi untuk mereka belajar dengan lebih cepat, lebih baik, dan lebih cerdas. Dan teknologi informasi menjadi kunci menuju sekolah masa depan yang lebih baik.

Banyak aspek dapat diajukan untuk dijadikan sebagai alas an untuk mendukung pengembangan dan penerapan IT untuk pendidikan dalam kaitannya dengan peningktan

82 | Teknologi, Informasi, dan Komunikasi 
kualitas pendidikan nasional Indonesia. Salah satu aspeknya ialah kondisi geografis Indonesia dengan sekian banyaknya pulau yang terpencar - pencar dan kontur permukaan buminya yang sering kali tidak bersahabat, biasanya diajukan untuk menjagokan pengembangan dan penerapan IT di bumi nusantara, sebab IT yang mengandalkan kemampuan pembelajaran jarak jauhnya tidak terpisah oleh ruang, jarak dan waktu. Demi penggapaian daerah-daerah yang sulit tentunya diharapkan penerapan ini agar dilakukan sesegera mungkin di Indonesia.

Pesatnya perkembangan IT, khususnya internet , memungkingkan pengembangan layanan informasi yang lebih baik dalam suatu institusi pendidikan. Di lingkungan perguruan tinggi, pemanfaatan IT lainnya yaitu diwujudkan dalam suatu sistem yang disebut electronic univercity. Pengembangan e-university bertujuan untuk mendukung penyelenggaraan pendidikan, sehingga perguruan tinggi dapat menyediakan layanan informasi yang lebih baik kepada komunitasnya, baik didalam maupun diluar perguruan tinggi tersebut melalui internet. Layanan pendidikan lain yang bisa dilaksanakan melalui sarana internet yaitu dengan menyediakan materi kuliah secara online dan materi kuliah tersebut dapat diakses oleh siapa saja yang membutuhkan. Hal ini juga tentunya sangat membantu bagi calon mahasiswa maupun mahasiswa atau bahkan alumni yang membutuhkan informasi tentang biaya kuliah, kurikulum, dosen pembimbing, atau banyak yang lainnya.

83 | Teknologi, Informasi, dan Komunikasi 


\section{IT Pembelajaran Berbasis Multimedia}

Peningkatan mutu pendidikan merupakan salah satu unsur konkrit yang sangat penting dalam upaya peningkatan kualitas sumber daya manusia. Sejalan dengan itu, hal yang sangat penting untuk diperhatikan adalah masalah prestasi belajar. Masalah umum yang sering dihadapi oleh peserta didik khususnya siswa masih cukup banyak yang belum dapat mencapai prestasi belajar yang memuaskan. Sebenarnya banyak faktor yang menyebabkan prestasi belajar tersebut mengalami kegagalan dalam bidang akademik baik faktorfaktor yang berada dalam diri siswa maupun faktor-faktor yang berada diluar diri siswa seperti tingkat intelegensi yang rendah, kurangnya motivasi belajar, cara belajar yang kurang efektif, minimnya frekuensi dan jumlah waktu belajar, tingkat disiplin diri yang rendah, media belajar atau bahan ajar yang masih kurang disediakan pihak sekolah dan sebagainya.

Demi mencapai prestasi belajar yang memuaskan tersebut dengan sistem pendidikan yang semakin maju dan didukung juga perkembangan teknologi. Teknologi multimedia telah menjanjikan potensi besar dalam merubah cara seseorang untuk belajar, untuk memperoleh informasi, menyesuaikan informasi dan sebagainya. Pembelajaran berbasis multimedia menjadi semakin umum. Meskipun memiliki keterbatasan,dan tentu tidak harus dilihat sebagai pengganti untuk wajah-to-face interaksi, itu memang memiliki banyak keuntungan untuk pengembangan guru profesional.

Multimedia juga menyediakan peluang bagi pendidik untuk mengembangkan teknik pembelajaran sehingga 84 | Teknologi, Informasi, dan Komunikasi 
menghasilkan hasil yang maksimal. Demikian juga bagi peserta didik, dengan multimedia diharapkan mereka akan lebih mudah untuk menentukan dengan apa dan bagaiamana siswa dapat menyerap informasi secara cepat dan efisien. Sumber informasi tidak lagi terfokus pada teks dari buku semata-mata tetapi lebih luas dari itu. Kemampuan teknologi multimedia yang semakin baik dan berkembang akan menambah kemudahan dalam mendapatkan pengetahuan siswa.

Kerjasama antar pakar dan juga dengan mahasiswa yang letaknya berjauhan secara fisik dapat dilakukan dengan lebih mudah. Dahulu seseorang harus berkelana jauh menempuh ruang dan waktu untuk menemui seorang pakar untuk mendiskusikan sebuah masalah. Saat ini hal ini dapat dilakukan dari rumah dengan mengirimkan email. Makalah dan penelitihan dapat dilakukan dengan saling tukar menukar data melalui internet, vi email, ataupun dengan menggunakan mekanisme file sharring dan mailing list. Batasan geografis bukan menjadi masalah lagi, diharapkan di masa depan virtual university sehingga tercipta suatu sistem belajar mengajar yang efektif di dunia pendidikan.

Ada beberapa kendala di Indonesia yang menyebabkan IT dan Internet belum dapat digunakan Seoptimal mungkin. Kesiapan pemerintah Indonesia masih patut dipertanyakan dalam hal ini. Salah satu penyebab utama adalah kurangnya ketersediaan sumber daya manusia, proses transformasi teknologi, infrastruktur telekomunikasi dan perangkat hukumnya yang mengaturnya. Apakah infrastruktur hukum yang melandasi operasional pendidikan di Indonesia cukup memadai untuk menampung perkembangan baru berupa 85 | Teknologi, Informasi, dan Komunikasi 
penerapan IT untuk pendidikan ini. Sebab perlu diketahui bahwa cyber law belum diterapkan pada dunia hukum di Indonesia.

Selain itu masih terdapat kekurangan pada hal pengadaan infrastruktur teknologi telekomuniksai, multimedia dan informasi yang merupakan prasyarat terselenggaranya IT untuk pendidikan sementara personal komputer (PC) di Indonesia masih rendah. Biaya penggunaan jasa telekomunikasi juga masih mahal bahkan jaringan telepon masih belum tersedia diberbagai tempat di Indonesia. untuk itu perlu dipikirkan akses ke internet tanpa melalui komputer pribadi di rumah. Sementara itu tempat akses internet dapatdiperbesar jangkauannya melalui fasilitas di kampus, sekolahan, dan bahkan melalui warung Internet. Hal ini tentunya dihadapkan kembali kepada pihak pemerintah maupun pihak swasta; walaupun pada akhirnya terpulang juga pada pemerintah. Sebab pemerintahlah yang dapat menciptakan iklim kebijakan dan regulasi yang kondusif bagi investasi swasta di bidang pendidikan.

86 | Teknologi, informasi, dan Komunikasi 


\section{Rangkuman dan Soal}

1. WBI adalah pengajaran individual yang dikirim melalui jaringan komputer umum atau pribadi dan ditampilkan oleh web browser. Oleh karena itu kemajuan WBI akan terkait dengan kemajuan teknologi web (perangkat keras dan perangkat lunak) maupun Pertumbuhan jumlah situssitus web di dunia yang sangat cepat. Kemajuan perangkat keras ditandai dengan pemakaian teknologi ATM (asynchronous transfer mode) dan serat optis yang memungkinkan transfer data yang besar dan cepat

2. Tiga kriteria dasar yang ada dalam e-learning. 1) $e$ learning bersifat jaringan, yang membuatnya mampu memperbaiki secara cepat, menyimpan atau memunculkan kembali, mendistribusikan, dan sharing pembelajaran dan informasi; 2) e-learning dikirimkan kepada pengguna melalui komputer dengan menggunakan standar teknologi internet; 3) e-learning terfokus pada pandangan pembelajaran yang paling luas, solusi pembelajaran yang menggungguli paradigma tradisional dalam pelatihan

3. Dalam prakteknya e-learning memerlukan bantuan teknologi. Karena itu dikenal istilah: computer based learning (CBL) yaitu pembelajaran yang sepenuhnya menggunakan komputer; dan computer assisted learning (CAL) yaitu pembelajaran yang menggunakan alat bantu utama komputer.

4. Ada beberapa kendala di Indonesia yang menyebabkan IT dan Internet belum dapat digunakan Seoptimal

87 | Teknologi, Informasi, dan Komunikasi 
mungkin. Kesiapan pemerintah Indonesia masih patut dipertanyakan dalam hal ini. Salah satu penyebab utama adalah kurangnya ketersediaan sumber daya manusia, proses transformasi teknologi, infrastruktur telekomunikasi dan perangkat hukumnya yang mengaturnya.

\section{Latihan Soal}

1. Jelaskan apa yang dimaksud synchronous elearning) dan asynchronous elearning yang anda pahami?

2. Sebutkan dan jelaskan 3 karakteristik dari e-learning yang dapat diterapkan dalam pembelajaran di negara Indonesia?

3. Jelaskan e-learning dalam bentuk CBL dan CAL?

4. Jelaskan apa itu file sharring, mailing list, dan cyber law yang anda pahami!

88 | Teknologi, Informasi, dan Komunikasí 


\section{BAB VI \\ Pemanfaatan Media Pembelajaran}

Bab ini menjelaskan tentang pemanfaatan media dalam pembelajaran yakni kegiatan belajar mengajar yang melibatkan siswa dan guru dengan menggunakan berbagai sumber belajar baik dalam situasi kelas maupun diluar kelas. Dalam arti media yang digunakan untuk pembelajaran tidak selalu identik dengan situasi kelas dalam pola pengajaran konveksional namun proses belajar tanpa kehadiran gurupun dan lebih mengandalkan media termasuk dalam kegiatan pembelajaran. Misalnya e-learning, pembelajaran individual dengan CD interaktif, video interaktif dan lain - lain. Berdasarkar fungsi pemanfaatannya, terbagi antara lain: 1) digunakan untuk menunjang tercapainya tujuan tertentu dan penggunaannya dipadukan dengan proses belajar mengajar dalam situasi kelas; 2) penggunaan media di luar kelas, media ini tidak secara langsung dikendalikan oleh guru, namun digunakan oleh siswa sendiri tanpa instruksi guru atau melalui pengontrolan oleh orang tua siswa. Penggunaan media pembelajaran diluar situasi kelas dapat dibedakan dalam dua kelompok utama, yaitu penggunaan media tidak terprogram dalam penggunaan media secara terprogram.

Bab ini selanjutnya membahas lebih mendalam tentang pemanfaatan media pembelajaran yang terbagi atas.

1. Penggunaan Media Tidak Terprogram

2. Penggunaan Media Terprogram

3. Multimedia dalam Pembelajaran

4. Prinsip-prinsip Multimedia

89 | Teknologi, Informasi, dan Komunikasi 


\section{A. Penggunaan Media Tidak Terprogram}

Penggunaan media dapat terjadi di masyarakat luas. Hal ini ada kaitannya dengan keberadaan media massa yang ada di masyarakat, misalnya televisi, radio, penggunaan film melalui CD / DVD ROM, penggunaan media ini bersifat bebas yaitu bahwa media itu digunakan tanpa dikontrol atau diawasi dan tidak terprogram sesuai tuntutan kurikulum yang diberikan oleh guru atau sekolah. Pembuat media mendistribusikan program media tersebut di masyarakat, baik dengan cara menjual belikan maupun didistribusikan secara bebas dengan harapan media itu akan digunakan orang dalam menggunakannya mencapai tujuan tertentu. Pemakai media dalam menggunakannya menurut kebutuhan masing-masing. Sehingga penggunaan media didasarkan atas inisiatif sendiri tanpa disuruh oleh pihak sekolah, medianya pun dapat diperoleh dimana saja, misalnya di toko buku, supermarket, pameran pendidikan, dan lain-lain. Sebagai contoh jenis penggunaan media ialah:

1. Penggunaan kaset pelajaran bahasa Inggris. Orang yang merasa memerlukan program tersebut dapat membelinya secara bebas. Tidak hanya siswa sekolah tapi juaga orang tua atau masyarakat umum. Menggunakannyapun juga secara bebas, artinya kaset itu dapat digunakan kapan saja, dimana saja dan untuk kepentingan apa saja semuanya tergantung kepada pemilik kaset itu sendiri. Tidak ada orang yang ikut mengaturnya. Dalam istilah media konsep ini disebut media as a tools, media yang berfungsi sebagai alat untuk mempelajari materi tertentu.

2. Penggunaan siaran radio untuk pendidikan;

go | Teknologi, Informasi, dan Komunikasi 
Pada saat ini banyak siaran radio atau televisi yang bersifat pendidikan. Program-program itu disiarkan dengan maksud untuk menyampaikan pesan- pesan pendidikan tertentu. Penggunaan program itu kebanyakan tidak dikontrol oleh penyelenggara dan disiarkan dengan harapan didengarkan dan dimanfaatkan oleh orang. Artinya penyelenggara siaran tidak menilai sampai seberapa jauh pesan yang telah disampaikan kepada pendengar dan apa pengaruhnya terhadap kemampuan keterampilan dan sikap pendengar. Penggunaan media ini bersifat terbuka, siapapun dapat menggunakanya selain siswa juga yang lainnya.

\section{B. Penggunaan Media Terprogram}

Penggunaan media secara terprogram adalah bahwa media tersebut digunakan dalam suatu rangkaian kegiatan yang diatur secara sistematik untuk mencapai tujuan tertentu disesusikan dengan tuntutan kurikulum yang sedang berlaku. Bila media itu berupa media pembelajaran, sasaran didik (audience) diorganisasikan dengan baik hingga mereka dapat menggunakan media itu secara teratur, berkesinambungan dan mengikuti pola belajar mengajar tertentu. Biasanya siswa diatur dalam kelompok- kelompok belajar. Setiap kelompok dikuasai oleh pimpinan kelompok dan di supervisi oleh seorang tutor. Sebelum memanfaatkan media, tujuan pembelajaran yang akan dicapai dibahas atau ditentukan terlebih dahulu. Kemudian mereka dapat belajar dari media tersebut secara berkelompok atau secara perorangan. Anggota kelompok diharapkan dapa berinteraksi baik dalam diskusi maupn dalam berkerjasama untuk memecahkan masalah,

91 | Teknologi, Informasi, dan Komunikasí 
memperdalam pemahaman atau penyesuaian tugas-tugas tertentu. Hasil belajar mereka di evaluasi secara teratur oleh pembuat program media dengan menyediakan alat evaluasi.

E-learning sebagai sistem pembelajaran memanfaatkan media elektronik sebagai alat utuk mambantu kegiatan pembeljaran. Sebagian besar berasumsi bahwa elektronik yang dimaksud di sini lebih diarahkan pada penggunaan teknologi komputer dan internet. Melalui komputer, siswa dapat belajar secara individual baik secara terprogram maupun tidak terprogram. Secara tidak terprogram siswa dapat mengakses berbagai bahan belajar dan informasi di internet menggunakan fasilitas di internet seperti mesin pencari data (search enggine).secara bebas siswa dapat mencari bahan daninformasi sesuai dengan minat masingmasing tanpa adanya intervensi dari siapapun. Sebagian besar komputer juga sering dimanfaatkan untuk hiburan seperti games, namun demikian hal tersebut tidak dapat dihindari seab penggunaan media elektronik bebas digunakan. Di Indonesia pada umumnya masih bersifat blended e-learning, yaitu e-learning bukan alat pembelajaran utama melainkan sebagai bahan dan alat pelengkap dari pembelajaran utama melainkan sebagai bahan dan alat pelengkap dari pembelajaran konvensioanal. Pembelajaran dengan kontrol guru di kelas masih tetap dominan, siswa belum secara totalitas menggunakan internet sebagai sistem pembelajarannya. Internet baru berfungsi sebagai suplemen dan belum sebagai komplemen atau panganti PBM konvensional. Dilihat dari variasi penggunaanya, media dapat digunakan baik secara perorangan, kelompok atau siswa dalam jumlah yang sangat banyak (massal).

92 | Teknologi, informasi, dan Komunikasi 
Media dapat digunakan oleh seseorang sendiri saja atau istilahnya individual learning, banyak media yang dirancang untuk digunakan secara perorangan (manual book) sehingga dapat digunakan secara mandiri. Buku petunjuk itu biasanya mengandung keterangan tentang tujuan pembelajaran yang akan dicapai, garis besar isi, dan urutan cara mempelajarinya. Karel ialah meja belajar yang disekat- sekat menjadi bagian kecil yang hanya cukup untuk duduk satu orang. Tiap karel dilengkapi perlengkapan media seperti tape recorder, proyektor film bingkai, earphone dan sebagainya.

Media yang dirancang untuk digunakan secara berkelompok juga memerlukan buku petunjuk. Buku petunjuk ini biasa ditujukan kepada pimpinan kelompok tutor atau guru. Keuntungan belajar menggunakan media secara berkelompok ialah bahwa kelompok itu dapat melakukan diskusi tentang apa yang sedang dipelajari. Media yang digunakan secara berkelompok harus memenuhi beberapa persyaratan: 1) suara yang disajikan harus cukup keras sehingga semua anggota kelompok dapat mendengarnya; 2) gambar atau tulisan harus cukup besar sehingga dapat dilihat oleh semua anggota kelompok; dan 3) perlu alat penyaji yang dapat memperkeras suara (amplifier) dan membesarkan gambar (proyektor).

Media yang dirancang untuk orang banyak/massal biasanya disiarkan melalui pemancar, seperti radio, televisi, atau digunakan dalam ruang yang besar seperti film. Media yang digunakan secara masal diantaranya televisi edukasi. TV dirancang untuk memenuhi kebutuhan akan siaran yang bernuasa pendidikan dan pembelajaran, sehingga programprogram yang diluncurkan syarat dengan pengetahuan, 93 | Teknologi, Informasi, dan Komunikasi 
keterampilan serta mendidik tentang nilai-nilai yang positif. Media ini bersifat masal karena disiarkan ke seluruh Indonesia seperti halnya televisi -televisi swata yang lainnya. Pada jam - jam tertentu siswa dapat mempelajari berbagai nateri pelajaran seperti : matamatika, fisika, bahasa inggris, bahasa Indonesia dan lain-lain.

\section{Multimedia dalam Pembelajaran}

Istilah "multimedia" bisa punya makna berlainan bagi banyak orang. Bagi sebagian orang, multimedia berarti menggunakan seperangkat komputeitr lengkap dengan segala fitur didalamnya. Bagi kalangan lainnya, multimedia bisa berarti presentasi "live" saat sekelompok orang duduk dalam satu ruangan sambil memandang gambar-gambar yang disajikan dalam satu atau lebih layar lebar dan mendengar musik atau suara lain yang disampaikan oleh pembicara. Multimedia adalah suatu sarana (media) yang didalamnya terdapat perpaduan (kombinasi) berbagai bentuk elemen informasi, seperti teks, graphics, animasi, video, interaktif maupun suara sebagai pendukung untuk mencapai tujuannya yaitu menyampaikan informasi atau sekedar memberikan hiburan bagi target audiens-nya.

Multimedia sering digunakan dalam dunia hiburan seperti game. Kata multimedia itu sendiri berasal dari kata multi yang berarti banyak dan kata media yang berarti sesuatu yang dipakai untuk menyampaikan sesuatu.

Media merupakan salah isu penting dalam proses pembelajaran. Media digunakan mendukung dalam menjembatani pebelajar dengan pusat serta sumber belajar.

94 | Teknologi, Informasi, dan Komunikasi 
Media seringkali menjadi sandaran utama dalam proses pembelajaran konvensional. Dimana dalam proses pembelajaran konvensional, strategi pembelajaran langsung berpusat pada seorang guru, dimana guru ini menjadi sumber dan sekaligus menjadi pusat dalam pembelajaran. Namun perkembangan yang kita alami saat ini dan mungkin juga dimasa mendatang dihadapkan pada perubahan yang telah menyebabkan perubahan pada segala lini kehidupan utamanya pada sektor pendidikan. Perkembangan teknologi ini telah menyasar pada perubahan insfrastruktur (jaringan) yang melahirkan pembelajaran berbasis jaringan. Kemajuan piranti keras dan lunak telah melahirkan pengaruh yang siginifikan pada perubahan conten dan program pembelajaran yang seringkali kerap kita dengar dengan isitlah e-learning, online learning, long distance learning, teleclassroom, computer aided instruction, computer mediated instruction, computer base training, CMS, LMS sampai pembelajaran berbasis web.

Begitu banyaknya istilah yang ada tentang media pembelajaran berbasis multimedia. Namun sebagai gambaran awal untuk memahami media pembelajaran. Multimedia terbagi menjadi dua kategori, yaitu: multimedia linier dan multimedia interaktif. Multimedia linier adalah suatu multimedia yang tidak dilengkapi dengan alat pengontrol dalam bentuk apapun yang dapat dioperasikan oleh pengguna. Multimedia ini berjalan sekuensial, misal TV dan film. Multimedia interaktif adalah suatu multimedia yang dilengkapi dengan alat pengontrol yang dapat dioperasikan oleh pengguna, sehinnga pengguna dapat memilih apa yang dikehendaki untuk proses selanjutnya, contoh multimedia 95 | Teknologi, Informasi, dan Komunikasi 
interaktif adalah pembelajaran interaktif, aplikasi game, dan lain-lain.

Multimedia telah banyak digunakan dalam pembelajaran. Menurut Istiyanto (2011), multimedia adalah media yang menggabungkan dua unsur atau lebih yang terdiri dari teks, grafik, gambar, foto, audio, dan animasi secara terintegrasi. Menurut Mayer (2009), multimedia didefinisikan sebagai presentasi materi dengan menggunakan katakata (verbal form) sekaligus gambar-gambar (pictorial form). Multimedia merupakan sarana pendukung yang pengiriman pesan-pesan pembelajaran (instruksional), yakni dengan memanfaatkan pancaindera manusia untuk menerima pesanpesan instruksional. Ada tiga sudut pandang multimedia yaitu media pengiriman, mode presentasi, dan modalitas sensori. Untuk lebih jelasnya dapat $d$ ilihat pada tabel berikut.

\section{Table 3. Tiga Pandangan Multimedia}

\begin{tabular}{|l|l|l|}
\hline \multicolumn{1}{|c|}{ Pandangan } & \multicolumn{1}{|c|}{ Definisi } & \multicolumn{1}{|c|}{ C } \\
\hline Media pengiriman & $\begin{array}{l}\text { Dua atau lebih alat } \\
\text { pengiriman }\end{array}$ & $\begin{array}{l}\text { Layar komputer, ampli } \\
\text { atau suara penceramah }\end{array}$ \\
\hline Mode Presentasi & $\begin{array}{l}\text { Refresentasi verbal } \\
\text { atau pictoral }\end{array}$ & $\begin{array}{l}\text { Teks on screen dan ani } \\
\text { ilustrasi }\end{array}$ \\
\hline Modalitas sensori & $\begin{array}{l}\text { Indra auditori atau } \\
\text { visual }\end{array}$ & Narasi dan animasi; ce \\
\hline
\end{tabular}

Pembelajaran berbantuan multimedia dapat diartikan sebagai aplikasi multimedia yang digunakan dalam proses pembelajaran, untuk menyalurkan pesan (pengetahuan, keterampilan dan sikap) serta dapat merangsang pikiran, g6 | Teknologi, informasi, dan Komunikasí 
perasaan, perhatian, dan kemauan belajar sehingga terjadi proses belajar yang sesuai tujuan dan terkendali (Istiyanto, 2011). Menurut Mayer (2009), asumsi yang mendasari teori kognitif tentang multimedia learning, yakni dual-channel (saluran ganda), limited capacity (kapasitas terbatas), dan active-processing (pemrosesan aktif). Asumsi saluran ganda (dual-channel assumption) menyatakan bahwa manusia memiliki saluran terpisah bagi pemrosesan informasi untuk materi visual dan materi auditori. Informasi berupa kata-kata diterima oleh mata dan telinga, sedangkan gambar diterima oleh mata yang merupakan memori sensorik. Setelah diseleksi oleh memori sensorik, informasi diteruskan ke memori kerja. Di dalam memori kerja, informasi diorganisasikan untuk diintegrasikan ke memori jangka panjang.

Menurut Sweller (2009), jika kapasitas kognitif siswa kelebihan beban (overload cognitive) maka pembelajaran akan terganggu. Sehingga untuk mengatasi kesulitan belajar siswa antara lain melalui pembelajaran yang efektif dengan mengelola beban kognitif intrinsik, mengurangi beban kognitif eraneous dan meningkatkan beban kognitif germane (Kalyuga, 2009). Mayer dan Moreno (2010:131) menegaskan bahwa untuk mewujudkan pembelajaran yang efektif dapat dibantu dengan multimedia, karena multimedia efektif untuk mengelola beban kognitif intrinsic, mengurangi beban kognitif extraneous dan meningkatkan beban kognitif germane.

Lebih lanjut Mayer (2009) menjelaskan bahwa multimedia menawarkan teknologi pembelajaran yang berpotensi kuat untuk meningkatkan kualitas pembelajaran g7 | Teknologi, Informasi, dan Komunikasi 
manusia. Pesan-pesan instruksional multimedia menawarkan teknologi pembelajaran yang berpotensi sangat kuat yakni, sistem untuk meningkatkan pembelajaran manusia. Tujuan praktis multimedia adalah merencanakan prinsip-prinsip desain untuk presentasi multimedia. Desain multimedia dalam pembelajaran berpusat pada dua pokok yaitu technology centered (berpusat pada teknologi multimedia) dan learner centered (berpusat pada subjek belajar/mahasiswa), secara ringkas dapat dilihat pada tabel berikut.

\section{Table 4 Pandangan tentang Desain Multimedia}

\begin{tabular}{|c|c|c|c|}
\hline $\begin{array}{l}\text { Pandangan } \\
\text { Desain }\end{array}$ & Titik Awalan & Tujuan & Isu-isu \\
\hline $\begin{array}{l}\text { Technology- } \\
\text { Centered }\end{array}$ & $\begin{array}{l}\text { Kapabilitas- } \\
\text { kapabilitas } \\
\text { teknologi } \\
\text { multimedia }\end{array}$ & $\begin{array}{l}\text { Memberi akses } \\
\text { ke informasi }\end{array}$ & $\begin{array}{l}\text { Bagaimana } \\
\text { seseorang } \\
\text { menggunakan } \\
\text { teknologi } \\
\text { canggih } \\
\text { dalam } \\
\text { mendesain } \\
\text { presentasi } \\
\text { multimedia }\end{array}$ \\
\hline $\begin{array}{l}\text { Learner- } \\
\text { Centered }\end{array}$ & $\begin{array}{l}\text { Bagaimana } \\
\text { otak manusia } \\
\text { bekerja }\end{array}$ & $\begin{array}{l}\text { Membantu } \\
\text { kognisi } \\
\text { manusia }\end{array}$ & $\begin{array}{l}\text { Bagaimana } \\
\text { seseorang } \\
\text { mengadaptasi } \\
\text { teknologi } \\
\text { multimedia } \\
\text { untuk } \\
\text { membantu } \\
\text { kognisi } \\
\text { manusia }\end{array}$ \\
\hline
\end{tabular}

98 | Teknologi, Informasi, dan Komunikasi 
Penyampaian pesan pembelajaran melalui multimedia, memberikan kemudahan-kemudahan bagi pembelajar (mahasiswa) untuk dapat memahami sesuai yang diajarkan. Teknologi informasi sangat memungkinkan untuk menyiapkan aplikasi multimedia pembelajaran, sehingga keberhasilan pembelajaran dapat didukung dengan aplikasi teknologi informasi multimedia. Gambar atau bentuk visual banyak digunakan dalam berbagai kesempatan, setidaknya ada beberapa alasan yang menyebabkan gambar banyak digunakan dalam pembuatan bahan ajar, sebagaimana diuraikan Prastowo (2012) berikut ini, yaitu: 1) gambar dapat menjadi hiasan yang membuat bahan ajar menjadi menarik peserta didik, rasa bosan yang mungkin muncul pada peserta didikpun dapat diatasi, 2) gambar mampu memberikan motivasi, 3) gambar sebagai penyampai pesan, melalui gambar dapat dikirimkan pesan yang mencerminkan niat untuk mencapai target tertentu, 4) gambar dapat mempengaruhi orang yang melihatnya, dan 5) dengan gambar, informasi yang ingin disampaikan dapat lebih jelas dipahami, sebab informasi yang berbentuk naratif seringkali sering kali masih kurang mencukupi untuk dipahami peserta didik.

Satu gambar dapat memiliki lebih dari satu fungsi pada waktu yang bersamaan, berikut ini hal-hal penting yang mesti diperhatikan berkaiatan dengan penggunaan gambar, yakni: 1) terangkan fungsi gambar dengan sejelas-jelasnya untuk menjelaskan secara eksplisit, sehingga peserta didik memperhatikan gambar tersebut, 2) seimbangkan fungsi, jangan sampai fungsi gambar yang lebih minor (tambahan) berakibat negative terhadap fungsi mayor (utama) yang 99 | Teknologi, Informasi, dan Komunikasi 
sebenarnya, 3) tentukan aktivitas yang harus dilakukan peserta didik. Apabila menggunakan gambar, maka pastikan peserta didik membaca gambar tersebut untuk dapat memahami materi, 4) batasi informasi, jangan memunculkan banya.k informasi dalam satu gambar, walaupun secara teori satu gambar dapat memberikan banyak informasi, cobalah untuk membatasi informasi yang ingin disampaikan, dan 5) hindari SARA, artinya jangan menggunakan gambar yang dapat memicu SARA dan bias gender.

\section{Prinsip-prinsip Multimedia}

Dewasa ini multimedia pembelajaran berbasis ICT berkembang cukup pesat, hal ini tentu disebabkan oleh pengaruh perkembangan perangkat teknologi khususnya komputer yang semakin canggih dan murah serta telah menyentuh hampir semua lapisan masyarakat. Multimedia pembelajaran yang dikembangkan oleh mahasiswa, praktisi dan akademisi telah banyak dimanfaatkan oleh siswa atau pembelajar untuk membantu pemahaman materi yang ingin mereka pelajari, bahkan multimedia telah menjadi alternatif pilihan utama bagi siswa untuk belajar secara mandiri selain buku teks atau buku sumber.

Pembelajaran jenis ini merupakan terobosan baru dalam zaman informasi yang menuntut segalanya berjalan dengan cepat. Pembelajaran dengan multimedia merupakan gabungan dari berbagai macam media yang terintegrasi yang secara bersama-sama menampilkan informasi, pesan, atau isi pelajaran. Konsep penggabungan ini dengan sendirinya memerlukan beberapa jenis peralatan perangkat keras yang

100 | Teknologi, Informasi, dan Komunikasi 
masing-masing tetap menjalankan fungsi utamanya sebagaimana biasanya, dan komputer merupakan pengendali seluruh peralatan itu. Jenis peralatan itu adalah komputer, video kamera, video casette recorder (VCR), overhead projector, multivision (atau sejenisnya), CD player, campact disc. CD Player yang sebelumnya merupakan peralatan tambahan (exsternal peripheral) komputer.

Kesemua peralatan itu haruslah kompak dan bekerja sama dengan menyampaikan informasi kepada pemakainya. Informasi yang disampaikan melalui multimedia ini berbentuk dokumen yang hidup, dapat dilihat dilayar monitor atau ketika diproyeksikan ke layar lebar melalui overhead projector, dan dapat didengar suaranya, dilihat gerakannya (video atau animasi). Multimedia bertujuan untuk menyajikan informasi dalam bentuk yang menyenangkan, manarik, mudah dimengerti, dan jelas. Informasi akan mudah dimengerti karena sebanyak mungkin indera, terutama telinga dan mata, digunakan untuk menyerap informasi itu.

Vaughan (2006) mengatakan multimedia merupakan kombinasi teks, seni, suara, animasi, dan video yang disampaikan kepada seorang (peserta didik) dengan komputer atau peralatan manipulasi elektronik dan digital yang lain. Melalui gabungan media-media ini pengalaman belajar menjadi sesuatu yang interaktif yang mencerminkan suatu pengalaman dalam kehidupan sehari-hari. Lebih lanjut Hofstetter yang dikutip Suyanto (2005: 21) menyatakan ada empat komponen penting multimedia; (1) harus ada komputer yang mengkoordinasikan apa yang dilihat dan didengar, yang berinteraksi dengan pengguna, (2) harus ada link yang 101 | Teknologi, Informasi, dan Komunikasi 
menghubungkan kita dengan informasi, (3) harus ada alat navigasi yang memandu pengguna menjelajah jaringan informasi, (4) multimedia menyediakan tempat kepada pengguna untuk mengumpulkan, memproses, mengomunikasikan informasi dan ide. Apabila salah satu komponen tidak ada, maka bukan multimedia dalam arti yang luas. Misalnya tidak ada komputer untuk berinteraksi, maka namanya media campuran, bukan multimedia. Kalau tidak ada alat navigasi yang memungkinkan kita memilih jalannya suatu tindakan maka namanya film, bukan multimedia.

Multimedia memungkinkan peserta didik untuk lebih mengenal dan terbiasa dengan komputer yang saat ini sudah sangat dikenal dan digunakan oleh banyak orang. Komputer merupakan media penyampai pembelajaran yang efektif. Hasil riset Beerman, Kathy (1996) menyebutkan bahwa menggunakan komputer mempunyai efek yang positif terhadap peserta didik. Richard E. Mayer (2009) menyatakan pesan multimedia yang dirancang dengan tata cara otak manusia bekerja akan lebih mungkin pembelajaran menjadi lebih bermakna dibandingkan dengan pesan multimedia yang tidak dirancang dengan mengikuti cara kerja otak manusia. Oleh karena itu Richard E. Mayer menawarkan lima tahapan dalam merancan pesan multimedia yaitu; (1) memilih katakata yang relevan dari teks dan narasi yang tersaji, (2) memilih gambar-gambar yang relevan dari ilustrasi yang tersaji, (3) mengatur kata-kata yang terpilih kedalam represendasi verbal yang koheren, (4) mengatur gambargamabr yang tersaji kedalam representasi visual yang koheren dan (5) memadukan representasi verbal dan representasi visual secara koheren. Mayer (2009) menyebutkan tujuh 102 | Teknologi, Informasi, dan Komunikasi 
prinsip desain multimedia untuk dapat meningkatkan pemahaman dan kemampuan belajar siswa.

1. Prinsip multimedia, dimana siswa dapat belajar lebih baik menggunakann kata-kata dan gambar-gambar daripada hanya dengan kata-kata saja. Apabila seorang pendidik menginginkan peningkatan pemahaman dan meningkatkan kualitas pemahaman peserta didiknya, hendaknya memadukan dua hal yakni menggunakan kata-kata (teks) diikuti dengan sajian gambar.

2. Prinsip keterdekatan ruang, siswa dapat belajar lebih baik saat kata-kata dan gambar-gambar terkait disajikan secara berdekatan daripada saat disajikan saling terpisah. Gambar dan kata-kata yang disajikan haruslah berdekatan dalam on-screen. Gambar dan teks/ kata yang berjauhan akan menyulitkan bagi siswa untuk memahaminya.

3. Prinsip keterdekatan waktu Siswa dapat belajar lebih baik saat kata-kata dan gambar terkait disajikan secara simultan (berbarengan) daripada suksesif (bergantian). Untuk meningkatkan pemehaman siswa gambar dan teks/kata sebaiknya disajikan secara berbarengan dalam on screen bukan bergantian sebab jika disajikan secara bergantian dapat menyebabkan terjadi kesalahan dalam memproses informasi yaitu hubungan mental antara representasi verbal dan representasi visual tidak terjadi.

4. Prinsip koherensi, dimana siswa dapat belajar lebih baik saat kata-kata atau gambar-gambar yang menjadi unsur tambahan dalam pembelajaran dihilangkan dalam tampilan on screen, karena unsur tambahan tersebut akan mengalihkan perhatian siswa dari materi yang penting, bisa menggangu proses penataan materi, dan dapat 
menggiring siswa pada materi yang tidak sesuai dengan tujuan pembelajaran.

5. Prinsip modalitas, dimana siswa dapat belajar lebih baik dari animasi dan narasi daripada animasi dan teks onscreen. Penggunaan gambar-gambar dan kata-kata yang tidak berimbang akan menyebabkan saluran visual/pictorial kelebihan beban begitupula saluran auditori/verbal tidak termanfaatkan. Oleh karena itu dalam pengembangan multimedia saluaran visual dan auditori harus digunakan secara seimbang.

6. Prinsip redundansi, dimana siswa dapat belajar lebih baik dari animasi dan narasi daripada animasi, narasi dan teks on-screen.

7. Prinsip perbedaan individual, siswa berkemampuan spasial tinggi lebih baik daripada siswa berspasial rendah. Penggunaan multimedia sebainya digunakan pada siswa yang belum mempelajari materi bukan untuk mengulang (remidi), sebab siswa yang memiliki pengetahuan kurang tertarik pada unsur-unsur multimedia. Begitu juga siswa yang kemampuan spasial rendah juga tidak begitu tertarik dengan tampilan multimedia. 


\section{Rangkuman dan Soal}

1. Pembelajaran dengan multimedia merupakan gabungan dari berbagai macam media yang terintegrasi yang secara bersama-sama menampilkan informasi, pesan, atau isi pelajaran. Konsep penggabungan ini dengan sendirinya memerlukan beberapa jenis peralatan perangkat keras yang masing-masing tetap menjalankan fungsi utamanya sebagaimana biasanya, dan komputer merupakan pengendali seluruh peralatan itu.

2. Multimedia menawarkan teknologi pembelajaran yang berpotensi sangat kuat yakni, sistem untuk meningkatkan pembelajaran manusia. Tujuan praktis multimedia adalah merencanakan prinsip-prinsip desain untuk presentasi multimedia.

3. Desain multimedia dalam pembelajaran berpusat pada dua pokok yaitu technology centered (berpusat pada teknologi multimedia) dan learner centered (berpusat pada subjek belajar/mahasiswa)

4. Penggunaan media secara terprogram adalah bahwa media tersebut digunakan dalam suatu rangkaian kegiatan yang diatur secara sistematik untuk mencapai tujuan tertentu disesusikan dengan tuntutan kurikulum yang sedang berlaku. Bila media itu berupa media pembelajaran, sasaran didik (audience) diorganisasikan dengan baik hingga mereka dapat menggunakan media itu secara teratur, berkesinambungan dan mengikuti pola belajar mengajar tertentu.

\section{Latihan Soal}

1. Jelaskan bagaimana aplikasi pembelajaran yang menggunakan multimedia dan dengan e-learning dapat berjalan dengan maksimal?

105 | Teknologi, Informasi, dan Komunikasi 
2. Jelaskan apa yang dimaksud desain multimedia dalam pembelajaran berpusat technology centered dan learner centered?

3. Jelaskan perbedaan mengelola pembelajaran dengan menggunakan media secara terprogram dan tidak secara media terprogram dalam proses pembelajaran? 


\section{BAB VII Belajar Dengan Piranti Audio, Visual dan}

\section{Kinestetik}

Bab ini membahas tentang peran media sebagai sebuah alat yang mempunyai fungsi menyampaikan pesan dan menjadi salah satu faktor penentu keberhasilan pembelajaran. Melalui media, proses pembelajaran bisa lebih menarik dan menyenangkan, misalnya siswa yang memiliki ketertarikan terhadap warna dapat diberikan media dengan warna yang menarik, begitu juga dengan media-media yang lainnya. Sama juga dengan media teknologi, seperti halnya komputer yang banyak berisi tentang pembelajaran yang dikemas sangat menyenangkan buat siswa, sehingga siswa sangat tertarik dengan belajar melalui media. Maka di sinilah fungsi media sebagai alat bantu sangat memperjelas pesan pembelajaran. Sehingga siswa akan lebih tertarik untuk belajar. Keberhasilan penggunaan media tidak terlepas dari bagaimana media itu direncanakan dengan baik. Media yang dapat mengubah perilaku siswa, meningkatkan motivasi dan prestasi belajar tentu tidak dapat berlangsung secara spontanitas. Namun, diperlukan analisis yang komprehensif dengan memperhatikan berbagai aspek yang dapat mempengaruhi minat atau motivasi siswa untuk belajar, sehingga hasil pembelajaran yang optimal akan dapat dicapai sesuai dengan yang dicita-citakan.

Bab ini lebih lanjut membahas lebih detail tentang belajar dengan piranti audio, visual dan kinestetik, diantaranya.

1. Media Pembelajaran Visual

107 | Teknologi, Informasi, dan Komunikasi 
2. Fungsi Media Pembelajaran Visual

3. Manfaat Media Pembelajaran Visual

4. Jenis-jenis Media Pembelajaran Visual

5. Prinsip-prinsip Penggunaan Media Pembelajaran Visual

6. Kriteria Pemilihan Media Visual

7. Media Pembelajaran Audio dan Radio

8. Media Pembelajaran Kinestetik

\section{A. Media Pembelajaran Visual}

Di era globalisasi sekarang ini, tidak dapat dipungkiri lagi bahwasannya cukup banyak jenis dan bentuk media pembelajaran yang telah dikenal, mulai dari yang sederhana sampai yang berteknologi tinggi. Semakin lengkap media yang digunakan maka semakin baik hasil yang dicapai. Dilihat dari jenisnya media dibagi ke dalam media auditif, visual, dan audio visual. Media auditif adalah media yang banyak mengandalkan kemampuan suara saja, seperti radio, cassette recorder, piringan hitam, dan lain-lain. Media visual adalah media yang hanya mengandalkan indera penglihatan, seperti film strip, slide, film bisu, foto/ gambar, grafik, globe/ peta, chart/ bagan, diagram, OHP, dan lain-lain. Sedangkan media audio visual adalah media yang mempunyai unsur suara dan gambar. Jenis media ini mempunyai kemampuan yang lebih baik karena meliputi kedua jenis media yang pertama dan ke dua. Dari beberapa jenis dan bentuk media, kiranya patut menjadi perhatian dan pertimbangan agar dapat memilih media yang dianggap tepat untuk menunjang pencapaian tujuan pegajaran. Media yang sering dimanfaatkan dalam kegiatan pembelajaran adalah media 108 | Teknologi, Informasi, dan Komunikasi 
visual, karena media ini merupakan media yang sederhana dan mudah dijangkau baik dari kalangan ningrat sampai pada kalangan kurang mampu.

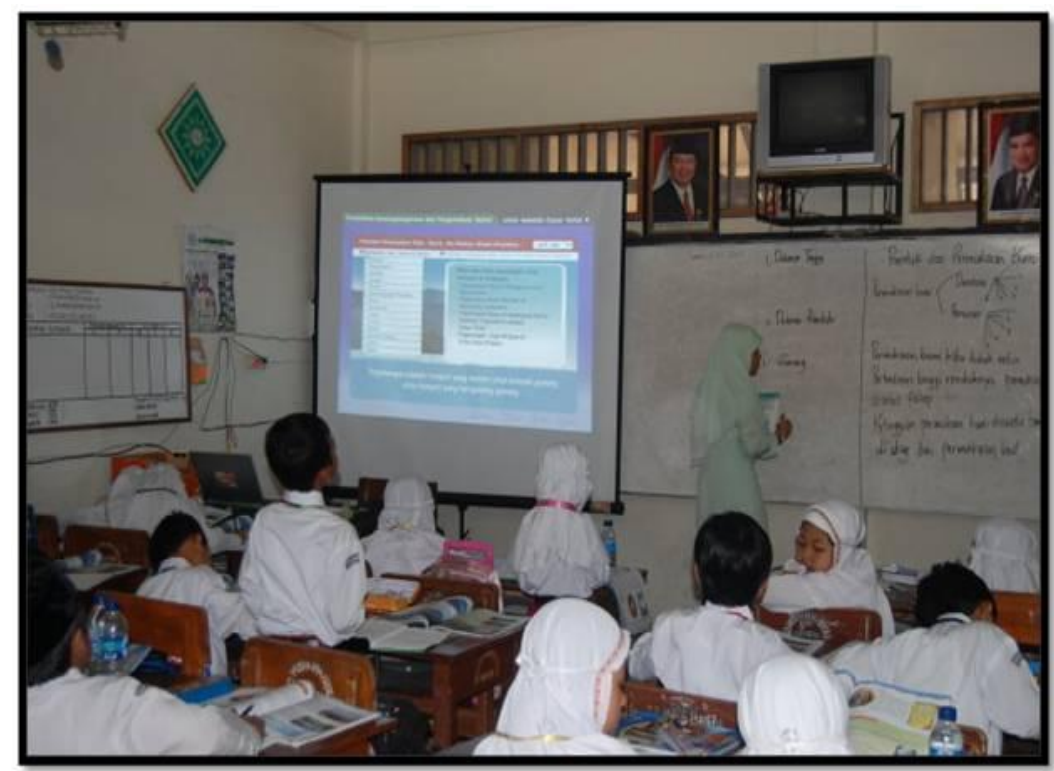

\section{Gambar 27. Media pembelajaran visual}

Lebih lanjut Tversky yang dikutip oleh Dwyer (1978) mengungkapkan bahwa informasi (pesan) verbal dan visual dapat dipahami secara berbeda tergantung atas penggunaan informasi yang diperoleh peserta belajar. Menurutnya, informasi visual akan diubah untuk disimpan dalam bentuk verbal simbolik. Namun ketika informasi ini akan diungkapkan kembali, maka terlebih dulu diubah dari bentuk verbal simbolik menjadi bentuk visual. Bahasa lisan dan tulisan menurut Su'udi (1990) merupakan simbol komunikasi verbal. Semestinya penggunaan simbol verbal ini tidaklah 109 |Teknologi, Informasi, dan Komunikasi 
mendominasi komunikasi dalam kegiatan pembelajaran. Selain menyangkut aspek proses belajar sebagai bentuk komunikasi, pembelajaran visual pun harus dikembangkan secara sistemik sampai pada aspek evaluasi. Bilamana proses komunikasi dalam pembelajaran berbentuk komunikasi visual, maka sudah seharusnya aspek evaluasi pun relevan dengannya.

Menurut Arsyad media berbasis visual (image atau perumpamaan) memegang peranan yang sangat penting dalam proses pmbelajaran. Media visual dapat memperlancar pemahaman dan memperkuat ingatan. Visual dapat pula menumbuhkan minat siswa serta dapat memberikan hubungan antara isi materi pelajaran dengan dunia nyata. Agar menjadi efektif, visual sebaiknya ditempatkan pada konteks yang bermakna dan siswa harus berinteraksi dengan visual (image) itu untuk meyakinkan terjadinya proses informasi.

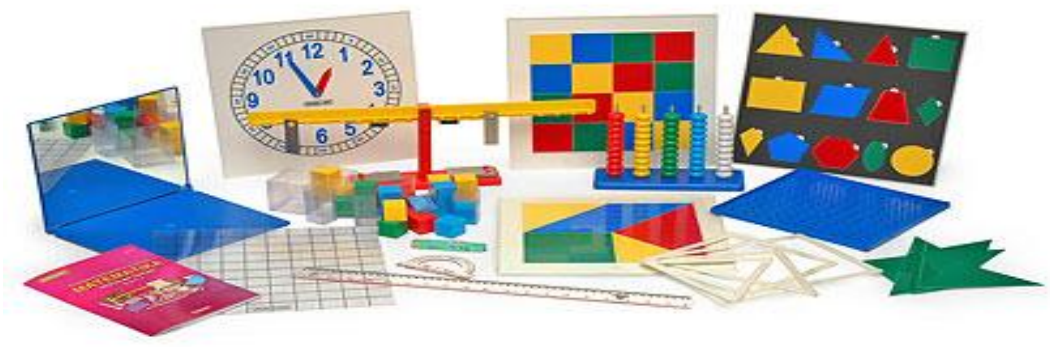

Gambar 28. Ragam media pembelajaran visual

110 | Teknologi, Informasi, dan Komunikasi 
Gambar diatas tentunya menganjurkan bagi setiap guru memanfaatkan media sebagai alat bantu, jadi kesannya dalam kegiatan pembelajaran itu tidak monoton, misalnya hanya guru saja yang merupakan satu-satunya sumber belajar sehingga kegiatan pembelajaran cenderung masih tradisional. Namun anjuran agar memanfaatkan media tersebut terkadang sukar dilaksanakan. Ada beberapa faktor mengapa pendidik sukar menerapkan media sebagai salah satu sumber belajar. Salah satu dari faktor tersebut karena dana yang terbatas. Untuk tercapainya tujuan pengajaran tidak harus dilihat dari mahalnya suatu media, karena media sederhana juga bisa mencapainya asalkan guru pandai memanfaatkannya. Guru yang pandai memanfaatkan media adalah guru yang bisa memanipulasi media sebagai sumber belajar dan sebagai penyalur informasi dari bahan yang disampaikan kepada anak didik dari proses belajar mengajar. Jadi dari sini dapat difahami bahwasannya, kehadiran media dalam proses pengajaran tidak boleh dipaksakan sehingga mempersulit tugas guru, tetapi harus sebaliknya, yakni mempermudah guru dalam menjelaskan bahan pengajaran. Karena itu, media bukan keharusan, tetapi sebagai pelengkap jika dipandang penting untuk mempertinggi kualitas belajar mengajar.

Ibrahim dalam bukunya Azhar Arsyad menjelaskan betapa pentingnya media pembelajaran karena media pembelajaran mampu membangkitkan rasa senang dan gembira bagi siswa dan memperbarui semangat mereka membantu menetapkan pengetahuan pada benak para siswa. Akhirnya dapat dipahami, bahwasannya media adalah bagian yang tidak dapat terpisahkan dari proses belajar mengajar karena media pembelajaran dapat membangkitkan Prestasi 111 | Teknologi, Informasi, dan Komuníkasí 
Belajar siswa dan rangsangan kegiatan belajar serta dapat memperlancar/ mempermudah pencapaian tujuan pengajaran. Dan gurulah yang memanfaatkannya untuk membelajarkan anak didik demi tercapainya tujuan pengajaran yang telah dirumuskan.

\section{B. Fungsi Media Pembelajaran Visual}

Levie dan Lentz (1982) dalam bukunya Azhar Arsyad mengemukakan 4 fungsi media pembelajaran visual, yaitu fungsi atensi merupakan inti yaitu menarik dan mengarahkan perhatian siswa untuk berkonsentrasi kepada isi pelajaran yang berkaitan dengan makna visual yang ditampilkan atau menyertai teks materi pengajaran. Sering kali pada awal pelajaran siswa tidak tertarik dengan materi pelajaran karena itu merupakan pelajaran yang tidak disenangi oleh mereka sehingga mereka tidak memperhatikan.

Media gambar yang diproyeksikan dapat menenangkan dan mengarahkan perhatian mereka kepada pelajaran yang akan mereka terima. Fungsi afektif, media visual dapat terlihat dari tingkat kenikmatan siswa ketika belajar (membaca) teks yang bergambar. Gambar atau lambang visual dapat menggugah emosi dan sikap siswa. Fungsi Kognitif, media visual terlihat dari temuan-temuan penelitian yang mengungkapkan bahwa lambang visual dapat memperlancar pencapaian tujuan untuk memahami dan mengingat informasi atau pesan yang terkandung dalam gambar. Fungsi Kompensatoris, media pembelajaran visual terlihat dari hasil penelitian bahwa media visual yang memberikan konteks untuk memahami teks membantu siswa 
yang lemah dalam membaca untuk mengorganisasikan informasi dalam teks dan mengingatnya kembali. Dengan kata lain, media pembelajaran berfungsi untuk mengakomodasikan siswa yang lambat menerima dan memahami isi pelajaran yang disajikan dengan teks atau secara verbal.

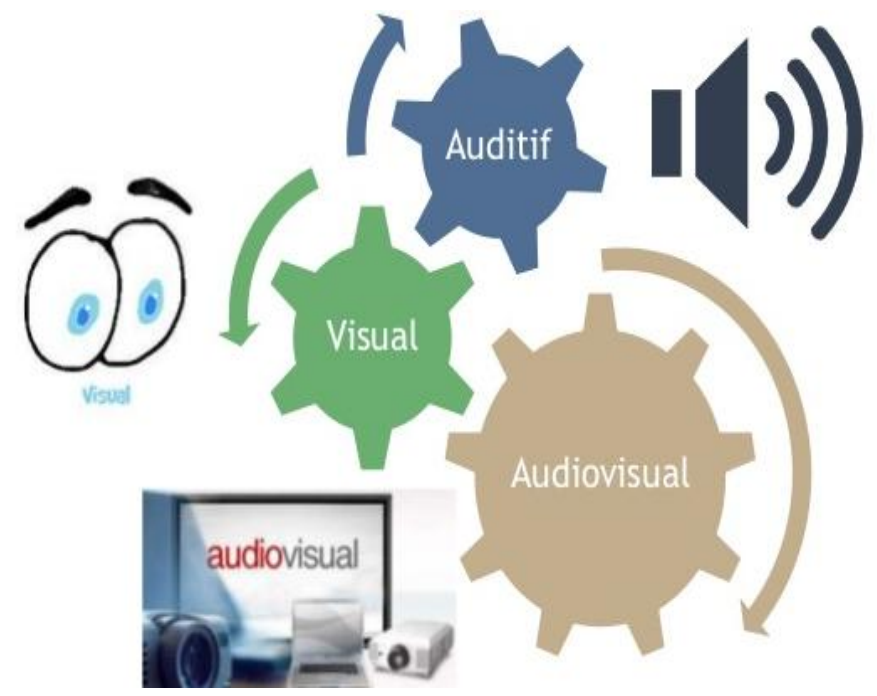

\section{Gambar 29. Kombinasi penggunaan media pembelajaran}

Pembelajaran adalah suatu kombinasi yang tersusun meliputi unsur-unsur manusiawi, material, fasilitas, perlengkapan, dan prosedur yang saling mempengaruhi mencapai tujuan pembelajaran. Manusia terlibat dalam sistem pengajaran tersendiri dari siswa, guru, dan tenaga lainnya, misalnya tenaga laboratorium. Material, meliputi buku-buku, papan tulis, alat tulis, fotografi, slide dan film, audio visual, juga komputer. Prosedur, meliputi jadwal dan metode 
penyampaian informasi praktik, belajar, ujian dan sebagainya (Oemar Hamalik, 2001).

Ada tiga ciri khas yang terkandung dalam sistem pembelajaran, ialah 1) rencana, ialah penataan ketenagaan, material, dan prosedur, yang merupakan unsur-unsur sistem pembelajaran, dalam suatu rencana khusus; 2) kesalingtergantungan, antara unsur-usur sistem pembelajaran yang serasi dalam suatu keseluruhan. Tiap unsur bersifat esensial, dan masing-masing memberikan sumbangannya kepada sistem pembelajaran; 3) tujuan sistem pembelajaran mempunyai tujuan tertentu yang hendak dicapai.

Dalam suatu proses belajar mengajar, dua hal yang sangat penting adalah metode mengajar dan media pembelajaran. Kedua aspek ini saling berkaitan. Pemilihan salah satu metode mengajar tertentu akan mempengaruhi jenis media pembelajaran yang sesuai, meskipun masih ada berbagai aspek lain yang harus diperhatikan dalam memili media pembelajaran, antara lain tujuan pembelajaran, jenis tugas dan respons yang diharapkan siswa. Meskipun demikian, dapat dikatakan bahwa salah satu fungsi utama media pembelajaran adalah sebagai alat untuk mengajar yang turut mempengaruhi iklim, kondisi, dan lingkungan belajar yang ditata dan diciptakan oleh guru.

Pemakaian media pembelajaran dalam proses belajar mengajar dapat membangkitkan minat dan keinginan yang baru, membangkitkan motivasi dan rangsangan kegiatan belajar, dan bahkan membawa pengaruh-pengaruh psikologis terhadap siswa. Penggunaan media pembelajaran pada tahap orientasi pengajaran akan sangat membantu keefektifan 
proses pembelajaran dan penyampaian pesan dan isi pelajaran pada saat itu.

\section{Manfaat Media Pembelajaran Visual}

Media pembelajaran dapat mempertinggi proses belajar siswa dalam pengajaran yang pada gilirannya diharapkan dapat mempertinggi hasil belajar yang dicapainya. Ada beberapa alasan, mengapa media pembelajaran dapat mempertinggi proses belajar siswa. Salah satu alasan tersebut berkenaan dengan manfaat media pembelajaran dalam proses belajar siswa, antara lain: 1) proses pembelajaran akan lebih menarik perhatian siswa; 2) bahan pengajaran akan lebih mudah difahami oleh siswa; c) metode pembelajaran akan lebih bervariasi dan tidak akan bersifat verbalistik; d) siswa akan dapat melakukan aktivitas, karena siswa tidak hanya mendengarkan tetapi juga dapat mengamati, mendemonstrasikan, memerankan, dan lain-lain. Firman Allah dalam Q.S. Al-furqon ayat (48)

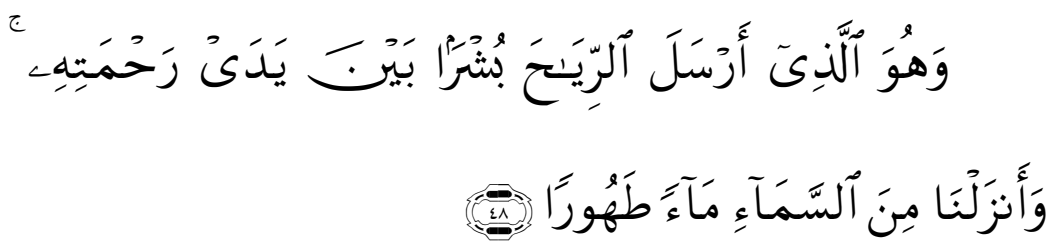

"Dia lah yang meniupkan angin (sebagai) pembawa kabar gembira dekat sebelum kedatangan rahmat-Nya (hujan); dan Kami turunkan dari langit air yang Amat bersih"

Dalam konteks Islam, penggunaan multi media tidak sekadar hanya memfungsikan sebagian fungsi komunikasi 115 | Teknologi, informasi, dan Komunikasi 
seperti menginformasikan, mendidik dan mempengaruhi saja, tetapi lebih pada mengoptimalisasikan upaya mengajak peserta didik untuk aktif mencari dan menyelidiki. Sehingga multimedia mengadopsi segala produk media komunikasi terutama multimedia berbasis teknologi informasi dan komunuikasi sebagai sarana komunikasi secara fundamental.

Dari sini dapat diketahui, bahwa penggunaan media pembelajaran dalam kegiatan pembelajaran dapat menarik perhatian siswa sehingga peserta didik dapat lebih mudah memahami materi yang disampaikan guru. Media pembelajaran juga dapat mewakili apa yang kurang mampu guru ucapkan melalui kata-kata atau kalimat yang bersifat verbalistik, bahkan keabstrakan bahan dapat dikonkritkan dengan menghadirkan media. Contoh sederhana, penggunaan peta atau globe dalam pelajaran ilmu bumi, pada dasarnya merupakan penyederhanaan dan pengkonkritan dari konsep geografis, sehingga dapat dipelajari dalam wujud yang mudah oleh peserta didik.

\section{Jenis-jenis Media Pembelajaran Visual}

Cukup banyak jenis dan bentuk media pembelajaran visual yang dikenal dewasa ini, dari yang cukup sederhana sampai yang berteknologi tinggi, dari yang mudah dan sudah ada secara natural sampai kepada media yang harus dirancang sendiri oleh guru. Banyak kebudayaan di dunia yang memberi pengaruh terhadap masyarakatnya menjadi sangat sensitif dan memiliki kapabilitas untuk memahami pesan melalui rangsangan visual /indera penglihatan. Oleh karena itu pesan visual sudah sangat familier dalam kehidupan manusia. Baik masyarakat tradisional maupun masyarakat modern masih banyak melakukan komunikasi secara visual dan bahkan 116 | Teknologi, Informasi, dan Komunikasi 
mengisi sebagaian besar waktunya saat tidak tidur. Hadirnya televisi mampu menyeret warga dunia untuk terlibat secara intens berkomunikasi melalui media ini. Apalagi sekaran muncul teknologi internet semakin menambah maraknya komunikasi visual.. Pada awalnya dalam konsep sistem informasi tradisional, manusia merupakan komponen utama dalam mengolah data menjadi informasi. Gambar berikut menunjukkan model dasar sistem tradisional, di mana manusia sebagai pengolah informasi.

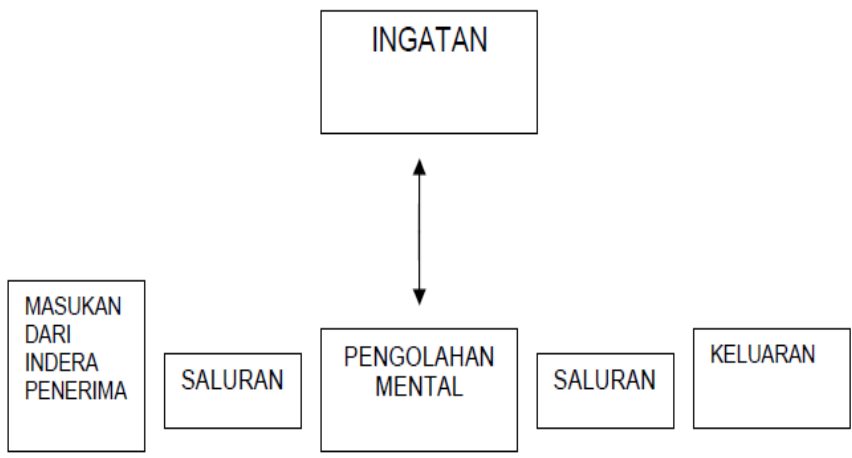

\section{Gambar 30. Sistem pengolah informasi tradisional}

Kapasitas manusia dalam menerima masukan dan menghasilkan keluaran adalah terbatas. Kenyataan lebih banyak menyediakan masukan dari pada yang dapat diterima oleh sistem pengolahan manusia. Manusia mengurangi masukan sampai batas tertentu. Oleh karenanya kemasan informasi sangat menentukan kapasitas informasi. Sebagai ilustrasi adalah pesan/informasi yang dikemas dalam bentuk gambar jauh lebih efisien daripada informasi dalam bentuk 117 | Teknologi, informasi, dan Komunikasi 
simbol verbal. Kata pepatah, satu gambar setara dengan seribu kata-kata. Konon menurut para ahli komunikasi, delapan puluh persen kegiatan manusia dalam mendapatkan informasi diperoleh melalui indera penglihatan (visual) Tentu saja ini berlaku untuk orang yang secara normal dapat melihat.

Menurut Plato, bahasa visual merupakan bahasa universal yang tidak terintangi oleh perbedaan makna katakata dari beragam bahasa yang ada di dunia. Ini berarti bahwa bahasa visual mempunyai arti yang sama untuk setiap orang yang menerimanya. Yang disebut visual adalah apa yang dapat dilihat, sehingga semua hal yang dapat dilihat masuk kategori visual. Konsep visual ini dapat dijelaskan dengan rangsangan yang mengenai indera penglihatan. Kita tidak bisa membayangkan bagaimana buku-buku pelajaran bahasa kedua tanpa gambar, mirip seperti buku-buku teks yang kering. Media audio berkaitan dengan indera pendengaran. Contohnya bisa mulai dari piringan hitam, kaset, audio CD, radio, hingga $\mathrm{mp} 3$.

Media audio-visual merupakan media yang menggabungkan indera pendengar dan penglihatan sekaligus. Televisi, video, film, VCD, dan sejumlah media sejenis lainnya seringkali dimanfaatkan untuk media pembelajaran. Kini hampir semua pembelajaran bahasa sudah meninggalkan kaset video dan menggantinya dengan cakram (VCD atau DVD) atau flashdisc yang berisi program-program pembelajaran yang bisa dioperasikan lewat komputer menjadi lebih praktis. Untuk mencapai suatu pengertian maka seseorang harus meresapkan apa yang dilihatnya ke otak sekaligus mengkaitkan dengan maklumat yang telah dimiliki 118 | Teknologi, Informasi, dan Komunikasi 
sebelumnya. Komunikasi visual ini sangat efektif. Efektivitas sejumlah indera untuk menerima rangsangan yakni sebagai berikut

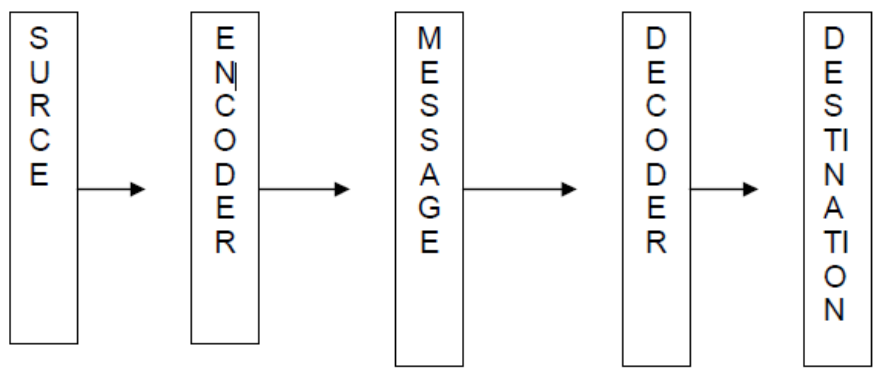

\section{Gambar 31. Proses komunikasi visual}

Media berbasis visual (image atau perumpamaan) memegang peranan yang sangat penting dalam proses belajar. Media visual dapat memperlancar pemahaman (misalnya melalui elaborasi struktur dan organisasi) dan memperkuat ingatan. Visual dapat pula menumbuhkan minat siswa dan dapat memberikan hubungan antara isi materi pelajaran dengan dunia nyata. Agar menjadi efektif, visual sebaiknya ditempatkan pada konteks yang bermakna dan siswa harus berinteraksi dengan visual (image) itu untuk meyakinkan terjadinya proses informasi. Bentuk visual bisa berupa (a) gambar representasi seperti gambar, lukisan atau foto yang menunjukkan bagaimana tampaknya

sesuatu benda; (b) diagram yang melukiskan hubunganhubungan konsep, organisasi, dan struktur isi materi; (c) peta yang menunjukkan hubungan-hubungan ruang antara unsurunsur dalam isi materi; (d) grafik seperti tabel, grafik.

119 | Teknologi, Informasi, dan Komunikasi 


\section{E. Prinsip-prinsip Penggunaan Media Pembelajaran Visual}

Ketika suatu media akan dipilih, ketika suatu media akan dipergunakan, ketika itulah beberapa rinsip perlu guru perhatikan dan pertimbangkan. Ada beberapa prinsip umum yang perlu diketahui guru ntuk penggunaan efektif media berbasis visual di antaranya yaitu: 1) berbentuk sederhana; 2) menekankan informasi sasaran sehingga pembelajaran dapat terlaksana dengan baik; 3) gunakan grafik untuk menggambarkan ikhtisar keseluruhan materi; 4) hindari visual yang tak-berimbang; 5) tekankan kejelasan dan ketepatan dalam semua visual ; 6) warna secara realistik digunakan untuk mengarahkan perhatian dan membedakan komponenkomponen.

Dari uraian di atas, dapat ditarik kesimpulan bahwa prinsip pokok yang harus diperhatikan dalam penggunaan media pembelajaran pada setiap kegiatan pembelajaran adalah bahwa media digunakan dan diarahkan untuk mempermudah siswa belajar dalam upaya memahami materi pelajaran. Penggunaan media harus dipandang dari sudut kebutuhan siswa. Hal ini perlu ditekankan sebab sering media dipersiapkan hanya dilihat dari sudut kepentingan guru. Contohnya, karena guru kurang menguasai bahan pelajaran yang akan diajarkan, maka guru mempersiapkan OHP, karena OHP digunakan untuk kepentingan guru, maka transparansi tidak di desain dengan menggunakan prinsip media pembelajaran, melainkan seluruh pesan yang ingin disampaikan dituliskan pada transparansi hingga menyerupai koran. Agar media pembelajaran benar-benar digunakan 120 |Teknologi, Informasi, dan Komunikasi 
untuk membelajarkan siswa maka dianjurkan pada setiap guru untuk selalu memperhatikan sejumlah prinsip-prinsip di atas dan chart (bagan) yang menyajikan gambaran/kecenderungan data atau antar

hubungan seperangkat gambar atau angka-angka.

\section{F. Kriteria Pemilihan Media Visual}

Media merupakan salah satu sarana untuk meningkatkan kegiatan proses belajar mengajar. Karena beraneka ragamnya media tersebut, maka masing-masing media mempunyai karakteristik yang berbeda-beda. Untuk itu, perlu pemilihannya dengan cermat dan tepat agar dapat digunakan secara tepat guna, beberapa pertimbangan yang perlu diperhatikan yaitu:

1. Media yang dipilih hendaknya selaras dan menunjang tujuan pembelajaran yang telah ditetapkan. Masalah tujuan pembelajaran ini merupakan komponen yang utama yang harus diperhatikan dalam memilih media,

2. Aspek materi menjadi pertimbangan yang dianggap penting dalam memilih media. Sesuai atau tidaknya materi dengan media yang digunakan akan berdampak pada hasil pembelajaran siswa.

3. Kondisi siswa dari segi subjek belajar menjadi perhatian yang serius bagi guru dalam pemilihan media yang sesuai dengan kondisi anak. Faktor umur, intelegensi, budaya, dan lingkungan anak menjadi titik perhatian dan pertimbangan dalam memilih media pengajaran,

4. Ketersediaan media di sekolah atau memungkinkan bagi guru mendesain sendiri media yang akan digunakan merupakan hal yang perlu menjadi pertimbangan seorang guru. Seringkali suatu media dianggap tepat untuk

121 | Teknologi, Informasi, dan Komuníkasi 
digunakan di kelas, akan tetap di sekolah tersebut tidak tersedia media atau peralatan yang diperlukan, sedangkan untuk mendesain suatu media yang dikehendaki tersebut tidak mungkin dilakukan oleh guru.

5. Media yang dipilih seharusnya dapat menjelaskan kepada siswa secara tepat dan berhasil guna, dengan kata lain tujuan yang ditetapkan dapat tercapai secara optimal.

6. Biaya yang akan dikeluarkan dalam penggunaan media harus seimbang dengan hasil yang dicapai. Penggunaan media yang sederhana mungkin lebih menguntungkan daripada memanfaatkan media yang canggih bilamana hasil yang dicapai tidak sebanding dengan dana yang diperlukan.

Dengan kriteria pemilihan media tersebut, guru dapat lebih mudah memanfaatkan media mana yang dianggap tepat untuk membantu mempermudah tugas-tugasnya sebagai pengajar. Kehadiran media dalam proses pembelajaran jangan dipaksakan sehingga mempersulit tugas guru, tetapi harus sebaliknya dengan mempermudah guru dalam menjelaskan bahan pengajaran. Media bukan keharusan tetapi sebagai pelengkap untuk mempertinggi kualitas belajar mengajar.

\section{G. Pemanfaatan Media Audio dan Radio}

Belajar tidak selamanya hanya bersentuhan dengan hal-hal yang kongkrit, baik dalam konsep maupun faktanya. Bahkan dalam realitasnya belajar seringkali bersentuhan dengan hal-hal yang bersifat kompleks, maya dan di balik realitas. Karena itu, media memiliki andil untuk menjelaskan hal-hal yang abstrak dan menunjukan hal-hal yang tersembunyi. Ketidak jelasan atau kerumitan bahan ajar dapat 122 | Teknologi, Informasi, dan Komunikasi 
dibantu dengan menghadirkan media sebagai perantara. Bahkan dalam hal-hal tertentu media dapat mewakili kekurangan guru dalam mengkomunikasikan materi pelajaran.

Banyak jenis ICT yang dapat dimanfaatkan sebagai media pembelajaran. Ada yang berbasis komputer, ada yang berbasis televisi, ada yang berbasis telephone yang berbasis audio. Media Dengar (Media Audio) adalah alat media yang isi pesannya hanya diterima melalui indera pendengaran saja. Media pembelajaran audio berupa suara-suara ataupun bunyi yang berkaitan dengan materi pembelajaran direkam dengan menggunakan alat perekam suara, kemudian hasil perekaman tersebut diperdengarkan kembali kepada peserta didik dengan menggunakan sebuah alat pemutarnya.

Media Audio Menurut Sadiman (2005) adalah media untuk menyampaikan pesan yang akan disampaikan dalam bentuk lambang-lambang auditif, baik verbal (ke dalam katakata atau bahasa lisan ) maupun non verbal. Sedangkan menurut Sudjana dan Rivai (2003) media audio untuk pengajaran adalah bahan yang mengandung pesan dalam bentuk auditif ( pita suara atau piringan suara), yang dapat merangsang pikiran, perasaan, perhatian dan kemauan siswa sehingga terjadi proses belajar mengajar.

Dari sisi fungsi media audio menurut Sudjana dan Rivai (1990 ) adalah untuk melatih segala kegiatan pengembangan keterampilan terutama yang berhubungan dengan aspek- aspek keterampilan pendengaran, yang dapat dicapai dengan media audio ialah antara lain: 1) pemusatan dan mempertahankan perhatian; 2) membantu konsentrasi mengikuti pengarahan; 3) melatih daya analisis; 4) 123 | Teknologi, Informasi, dan Komunikasi 
menentukan arti dan konteks; 5) memilah informasi dan gagasan; dan 6) merangkum, mengingat kembali dan menggali informasi.

Fungsi lain dari media audio adalah sebagai alat bantu bagi para pendidik, karena sifatnya hanya sekedar membantu, maka dalam pemanfaatannya memerlukan bantuan metode atau media lain, sehingga pengalaman dan pengetahuan siap dimiliki oleh pendengar yang akan membantu keberhasilan. Baik audio maupun radio dua-duanya merupakan media pembelajaran yang berbasis suara atau bunyi. Audio berasal dari kata audible, yang artinya suara yang dapat didengarkan secara wajar oleh telinga manusia. Kemampuan mendengar telinga manusia berada pada daerah frekuensi antara 20 sampai dengan 20.000 Hertz. Di luar itu, manusia tidak mampu lagi mendengarkannya. Ketika temannya menyanyi dan membaca puisi, mereka bisa mendengarkannya dengan baik, karena frekuensi suara yang dikeluarkan oleh kedua temannya tersebut masih berada pada daerah frekuensi antara 20 hingga 20.000 hertz. Sebailknya ketika melihat sekawanan semut yang sedang berjalan mereka tidak mendengarkan apa-apa, padahal sebenarnya gerakan semut tersebut juga mengeluarkan bunyi, hanya saja frekuensi bunyi yang dikeluarkannya di bawah 20 hertz, sehingga telinga kita tidak mampu mendengarkannya. Demikian pula ketika diminta untuk mendengarkan bunyi gerakan evolusi maupun revolusi bumi, telinga kita juga tidak mampu mendengarkannya, hal ini karena frekuensi suara yang dikeluarkannya melebihi 20.000 hertz, sehingga kita tidak mampu untuk menangkap bunyi dari gerakan bumi yang kita tempati ini.

124 | Teknologi, Informasi, dan Komunikasi 
Kaitannya Audio sebagai media pembelajaran, maka suara-suara ataupun bunyi direkam dengan menggunakan alat perekam suara, kemudian diperdengarkan kembali kepada peserta didik dengan menggunakan sebuah alat pemutar. Pengembangan dan pemanfaatan sumber belajar yang dapat menunjang dan mempermudah kegitan pembelajaran, merupakan upaya yang perlu dilakukan dalam meningkatkan mutu pembelajaran melalui pengembangan model pemanfaatan program kaset audio interaktif.

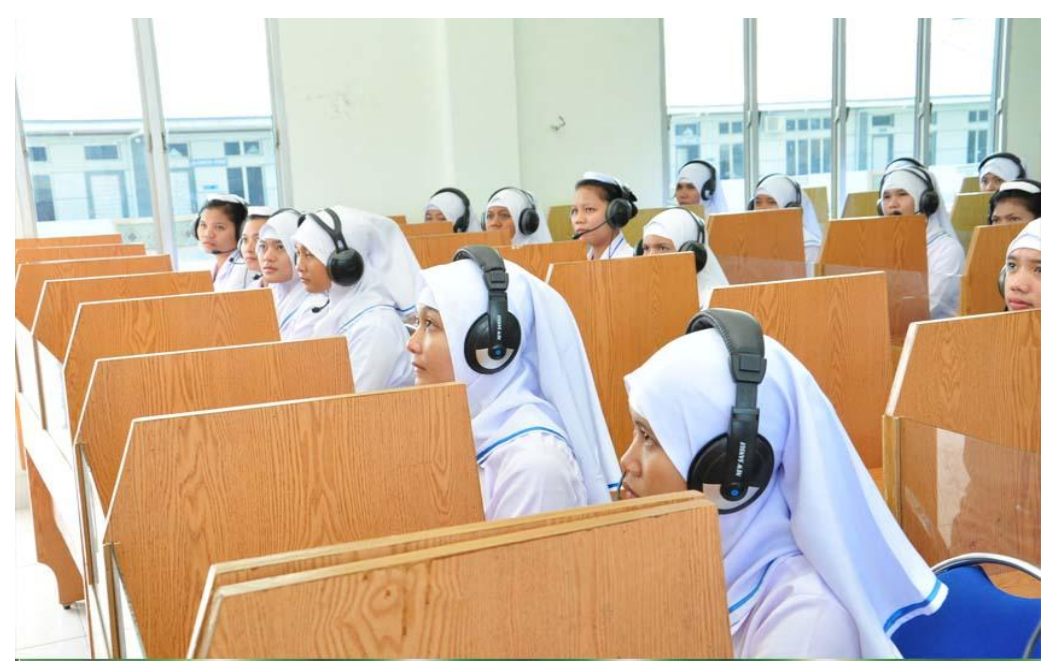

\section{Gambar 32. Pembelajaran melalui media audio}

Program kaset audio interaktif ini di desain sedemikian rupa sehingga peserta didik di mungkinkan dapat terlibat secara aktif dan terus-menerus berinteraksi dengan guru radio. Mengingingat pembelajaran yang harus selalu bersifat interaktif. Artinya peserta didik dapat memberikan respons setelah mendengarkan program program audio. Misalnya mengerjakan tugas latihan, mengucapkan dan sebagainya. 125 | Teknologi, Informasi, dan Komunikasí 
Media audio juga bisa dimanfaatkan untuk hampir semua topik, tipe pebelajar, dan setiap ranah: kognitif, afektif, psikomotorik, dan interpersonal. Pada ranah kognitif, pebelajar bisa mengobservasi rekreasi dramatis dari kejadian sejarah masa lalu dan rekaman aktual dari peristiwa terkini, karena unsur warna, suara dan gerak di sini mampu membuat karakter berasa lebih hidup.

Program audio mempunyai hubungan dengan tujuan pembelajaran kognitif, psikomotorik dan afektif, yakni 1) tujuan kognitif, audio dapat digunakan untuk mengajar pengenalan kembali dan pembedaan rangsang audio yang relevan; 2) tujuan psikomotor, program audio dapat digunakan untuk mengajar keterampilan verbal; dan 3) tujuan afektif, suara mungkin dapat diciptakan oleh musik latar, efek suara, suara narator. Program kaset audio interaktif dapat dimanfaatkan di dalam kelas di bawah dibawah bimbingan guru. Program yang di kemas di dalam kaset auidio ini memungkinkan peserta didik dapat belajar, baik secara individual maupun kelompok dengan atau tanpa bimbingan guru, berinteraksi engan program media audio pembelajaran. Interaksi peserta didik dapat berupa respons secara verbal terhadap latihan yang diberikan program audio. Selain itu, interaksi peserta didik juga dapat bersifat fisik, antara lain misalnya: menuliskan respons, menggerakkan anggota badan atau fisik, atau melakukan eksperimen yang di tuntun langsung oleh program audio.

Di dalam program kaset audio, di sediakan tempo (jeda) sehingga para peserta didik mempunyai waktu yang memadai untuk melakukan berbagai perintah yang di sampaikan oleh program audio. Setiap program audio diawali dengan musik 126 | Teknologi, Informasi, dan Komunikasi 
yang dapat mendorong terciptanya interaksi para peserta didik dengan program audio.

Adapun kelebihan pemanfaatan media kaset audio dalam kegiatan pembelajaran, antara lain sebagai berikut: 1) dapat diputar berulang-ulang tanpa mempengaruhi volume; 2) dapat dihapus secara otomatis dan pitanya bisa di pakai lagi; 3) dapat di gunakan sesuai jadal pelajaran yang ada; 4) dapat menyajikan kegiatan-kegiatan di luar sekolah (hasil wawancara, rekaman kegiatan, dll); 5) dapat memberikan efisiensi dalam pembelajaran bahasa; 6) penyajian sepenuhnya di control oleh penyaji; 7) biaya produksi dan penggandaannya relatif murah; dan 8) peralatannya juga paling murah dibanding dengan media audio visual lainnya. Sedangkan kelemahan kaset audio, antara lain sebagai berikut: 1) daya jangkauannya terbatas; 2) biaya jadi mahal apabila ingin disebarluaskan

\section{H. Media Pembelajaran Kinestetik}

Kecerdasan kinestetik merupakan suatu kecerdasan yang berhubungan dengan kemampuan dalam menggunakan tubuh secara terampil untuk melakukan gerakan-gerakan yang bagus, menggunakan keterampilan fisik dalam mengkoordinasikan seluruh tubuhnya dalam melakukan aktivitas untuk mengekspresikan ide dan perasaannya untuk menyelesaikan masalah. Seelfeldt dan Wasik (2008:95) memaparkan bahwa "Anak usia tiga, empat, dan lima tahun penuh dengan energi dan terus bergerak, waktu mereka tumbuh, keterampilan motorik kasar dan halus menjadi lebih cepat dan kemampuan mereka melakukan tugas yang menuntut keselarasan semakin baik".

127 | Teknologi, Informasi, dan Komunikasi 
Mengingat begitu pentingnya kemampuan kinestetik bagi anak, maka kemampuan kinestetik ini perlu diajarkan sejak dini, dengan berbagai media dan metode yang tepat yang tidak merusak pola perkembangan anak. Seperti riset yang dilakukan Ullman (Sujiono, 2009: 73) menemukan bahwa

anak-anak yang tidak disukai oleh lingkungan memiliki kemungkinan gagal di dalam sekolah mereka. Hal ini nantinya akan memungkinkan menyebabkan permasalahan sosial emosional ketika

mereka beranjak dewasa. Untuk membantu mengembangkan keterampilan sosial emosional anak usia dini terdapat banyak metode dan teknik yang dapat diterapkan.

Minat menghadirkan kegembiraan dalam belajar menjadi modal dasar belajar yang efektif bagi siswa dari setiap tingkatan umur atau kelas. Minat dalam belajar adalah suatu kekuatan yang dapat membuat anak didik tertarik kepada pelajaran. Anak didik yang mempunyai minat yang kuat terhadap suatu pelajaran akan mempelajari dengan sungguh-sungguh dan mengerahkan tenaga, pikiran, serta waktu tanpa ada suruhan atau paksaan dari orang lain.

Banyak jenis aktivitas yang dapat dilakukan siswa ketika belajar, tidak hanya menulis dan mendengarkan saja karena pelajaran tidak segera dikuasai dengan mendengarkan dan membacanya saja, tapi masih perlu lagi kegiatan-kegiatan lain seperti membuat rangkuman, mengerjakan tugas, mengadakan tanya jawab atau diskusi. Thomas M. Risk dalam bukunya Principles and Practices of Teaching yang dikutip oleh Zakiah Daradjat, mengatakan bahwa pengalaman 
belajar didapatkan siswa hanya dengan keaktifan sendiri bereaksi terhadap lingkungannya.

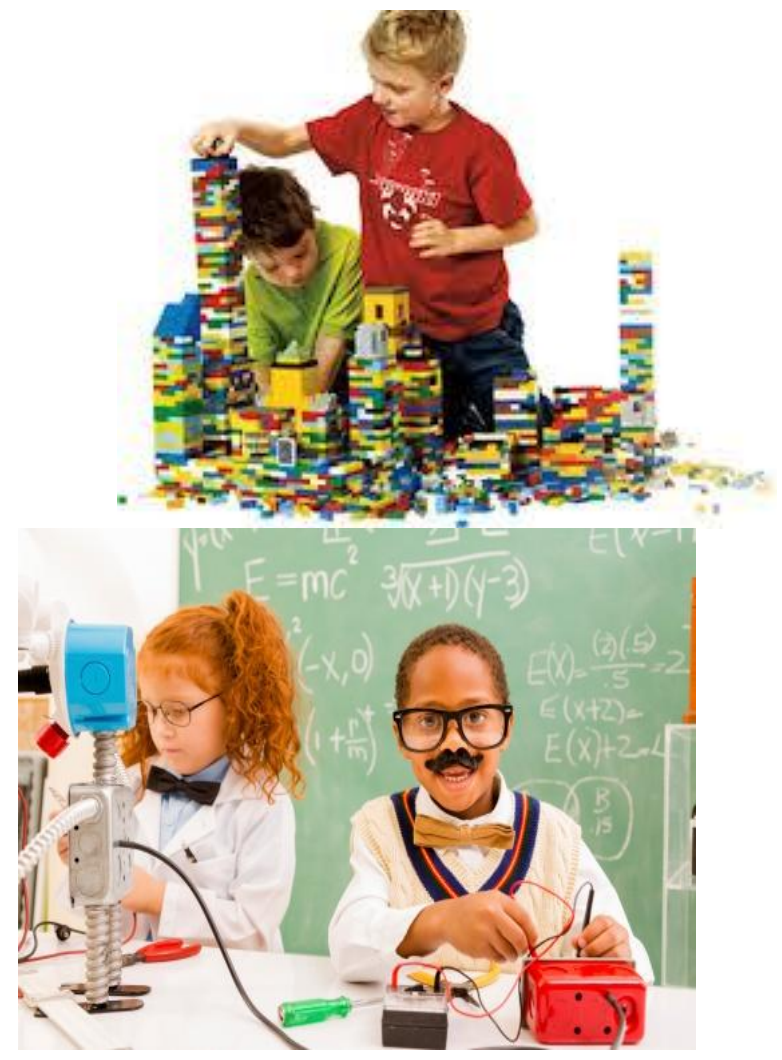

\section{Gambar 33. Belajar dengan kinestetik}

Bentuk kegiatan belajar lainnya berupa simulasi kehidupan melalui permainan-permainan (games) yang kreatif, rekreatif, dan edukatif, baik secara individual maupun kelompok dengan tujuan untuk pengembangan diri (personal development) maupun kelompok (team development). 129 | Teknologi, Informasi, dan Komunikasi 
Permainan dalam outbound dapat dijadikan sebagai terapi bagi anak yang bermasalah, seperti diungkapkan oleh Lesniak (Subagyo, 2013) bahwa keinginan anak, kebutuhan, dan perasaan, ditunjukkan melalui bermain. Setiap mainan yang dipilih oleh anak merupakan representasi/perwujudan dari apa yang dia sedang coba untuk sampaikan. Outbound menggunakan pendekatan belajar experintal learning karena pengalaman langsung membuat anak mudah menyerap pengetahuan yang anak alami sendiri (Rochmah, 2012).
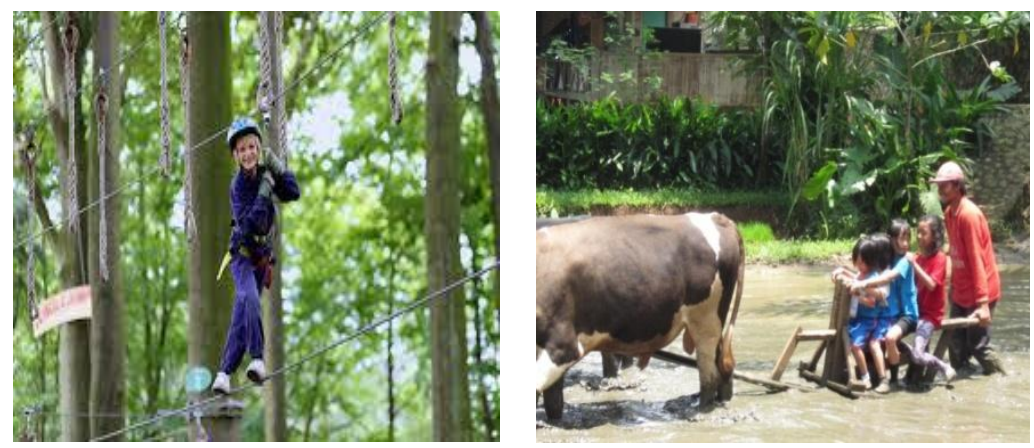

Gambar 34. Belajar melalui kegiatan outbound

Melakukan kegiatan outbound membantu mengekspresikan diri dan emosi anak, membantu dalam sosialisasi lingkungan sekitar anak, serta membantu anak mencari pengalaman secara langsung. Penyebab rendahnya kemampuan kinestetik anak disini adalah metode yang digunakan guru belum bervariasi, metode yang biasa digunakan adalah metode bercerita sehingga anak hanya mendengarkan saja dan cenderung pasif. Selain itu masih kurangnya kegiatan dalam mengembangkan gerak tubuh

130 | Teknologi, Informasi, dan Komunikasi 
melalui nyanyian, menselaraskan antara pikiran dan tubuh (koordinasi tubuh), mengembangkan kelincahan, kekuatan, dan keseimbangan tubuh serta mengkoordinasikan mata dengan tangan dan kaki sehingga merasa bosan dan acuh karena kegiatan motorik yang kurang variatif yaitu senam ceria. Apabila rendahnya kemampuan kinestetik anak tidak segera diatasi akan mempengaruhi perkembangan anak di tahap selanjutnya. Kelemahan tersebut dapat diatasi dengan suatu pembelajaran yang tepat, bermakna dan menyenangkan bagi anak.

Dalam proses pembelajaran terjadi komunikasi dua arah antara guru dan siswa. Tanpa adanya siswa maka kegiatan pembelajaran tidak akan berlangsung. Siswa harus bekerjasama secara aktif dalam mewujudkan tujuan yang telah ditetapkan.Aktivitas belajar merupakan kegiatan siswa selama proses pembelajaran berlangsung baik kegiatan jasmani maupun rohani. Tanpa adanya aktivitas dapat dikatakan bahwa siswa tidak belajar. Sebagaimana Nana Sudjana mengemukakan bahwa hasil belajar merupakan kemampuan-kemampuan yang dimiliki siswa setelah ia memperoleh pengalaman belajarnya. Pengalaman itu sendiri hanya mungkin diperoleh bila murid itu dengan keaktifan sendiri bereaksi terhadap lingkungannya.

131 |Teknologi, Informasi, dan Komunikasi 


\section{Rangkuman dan Soal}

1. Media berbasis visual (image atau perumpamaan) memegang peranan yang sangat penting dalam proses pmbelajaran. Media visual dapat memperlancar pemahaman dan memperkuat ingatan. Visual dapat pula menumbuhkan minat siswa serta dapat memberikan hubungan antara isi materi pelajaran dengan dunia nyata.

2. Media pembelajaran dapat mempertinggi proses belajar siswa. Salah satu alasan tersebut berkenaan dengan manfaat media pembelajaran dalam proses belajar siswa, antara lain: 1) proses pembelajaran akan lebih menarik perhatian siswa; 2) bahan pengajaran akan lebih mudah difahami oleh siswa; c) metode pembelajaran akan lebih bervariasi dan tidak akan bersifat verbalistik; d) siswa akan dapat melakukan aktivitas, karena siswa tidak hanya mendengarkan tetapi juga dapat mengamati, mendemonstrasikan, memerankan, dan lain-lain

3. Kapasitas manusia dalam menerima masukan dan menghasilkan keluaran adalah terbatas. Oleh karenanya kemasan informasi sangat menentukan kapasitas informasi. Sebagai ilustrasi adalah pesan/informasi yang dikemas dalam bentuk gambar jauh lebih efisien daripada informasi dalam bentuk simbol verbal.

4. Kriteria pemilihan media pembelajaran yang cermat dan tepat adalah: 1) media yang dipilih hendaknya selaras dan menunjang tujuan pembelajaran yang telah ditetapkan; 2) aspek materi menjadi pertimbangan yang dianggap penting dalam memilih media; 3 ) kondisi siswa

132 | Teknologi, informasi, dan Komunikasi 
dari segi subjek belajar menjadi perhatian yang serius bagi guru dalam pemilihan media yang sesuai dengan kondisi anak; 4) ketersediaan media di sekolah atau memungkinkan bagi guru mendesain sendiri media yang akan digunakan; 5) media yang dipilih seharusnya dapat menjelaskan apa yang akan disampaikan kepada siswa secara tepat dan berhasil guna; 6) biaya yang akan dikeluarkan dalam penggunaan media harus seimbang dengan hasil yang dicapai.

5. Kecerdasan kinestetik merupakan suatu kecerdasan yang berhubungan dengan kemampuan dalam menggunakan tubuh secara terampil untuk melakukan gerakan-gerakan yang bagus, menggunakan keterampilan fisik dalam mengkoordinasikan seluruh tubuhnya dalam melakukan aktivitas untuk mengekspresikan ide dan perasaannya untuk menyelesaikan masalah.

\section{Latihan Soal}

1. Jelaskan bagaimana sistem kerja media visual sehingga dapat memperlancar pemahaman dan memperkuat ingatan peserta didik?

2. Jelaskan mengapa media visual dapat meningkatkan minat belajar peserta didik?

3. Jelaskan yang dimaksud manusia memiliki kapasitas menerima masukan dan menghasilkan keluaran yang terbatas?

4. Sebutkan apa saja kriteria pemilihan media yang tepat?

133 | Teknologi, Informasi, dan Komunikasi 


\section{BAB VIII \\ Orientasi Pembelajaran Abad 21}

Bab ini menjelaskan tentang ciri menonjol pembelajaran abad-21 salah satunya adalah semakin bertautnya dunia ilmu dan teknologi, sehingga sinergi di antaranya menjadi semakin cepat. Teknologi informasi dan komunikasi atau ICT yang berkembang sangat pesat pada Dasawarsa terakhir ini membawa dampak yang luar biasa pada berbagai sektor kehidupan kita seperti bisnis, hiburan dan pendidikan. Pengaruh pada bidang pendidikan sangat jelas kita rasakan. Kita bisa melihat bagaimana ICT mempengaruhi para siswa belajar dengan sumber informasi yang begitu melimpah serta para guru mengubah cara mengajarnya. Kini kita juga bisa melihat bagaimana ICT mempengaruhi cara siswa maupun guru dalam berhubungan sosial, berinteraksi dan berkomunikasi dengan teman- teman mereka. Tantangan yang dihadapi para guru tentu tidak semakin ringan, karena siswa diharapkan bisa bersaing secara global yang bercirikan ICT. Guru saat ini tidak lagi sebagai pusat sumber belajar dan penyampai informasi utama, tetapi lebih dari itu yakni mampu berperan sebagai fasilitator, pendamping, pembimbing, dan sekaligus sebagai partner dalam mengembangkan skill dan pengetahuan. Potensi pemanfaatan ICT untuk meningkatkan akses pendidikan, meningkatkan efesiensi, serta kualitas pembelajaran dan pengajaran.

Bab ini akan diulas lebih mendalam tentang orientasi pembelajaran abad 21, diantaranya menyangkut.

134 | Teknologi, Informasi, dan Komunikasi 
1. Orientasi Baru Dunia Pendidikan

2. Paradigma Pendidikan Abad-21

3. Karakteristik Sekolah

4. Pembelajaran Berbasis Blended Learning

5. Mengembangkan Kecakapan Siswa

6. Desain Pembelajaran Berbasis Teknologi Informasi

7. Pembelajaran Secara Tatap Muka dan Virtual

8. Kompetensi Profesi Guru berbasis ICT

\section{A. Orientasi Baru Dunia Pendidikan}

Pendidikan yang ideal hakikatnya selalu bersifat antisipatif dan prepatoristik, yakni selalu mengacu ke masa depan, dan selalu mempersiapkan generasi muda untuk kehidupan masa depan yang jauh lebih baik, bermutu, dan bermakna. Sungguhpun demikian, apa dan bagaimana pendidikan ideal dengan sifatnya yang antisipatif dan prepatoristik seperti itu, berbeda bagi setiap bangsa dalam melihat dan menghadapi masa depannya. Bagi bangsa Indonesia, kondisi, tantangan, dan masalah masa depan yang harus dihadapi senantiasa berkaitan dengan pengembangan kualitas dan kemandirian manusia Indonesia yang memungkinkannya mampu dan proaktif menjawab tantangan globalisasi, baik di bidang sosial, budaya, ekonomi, politik, ilmu pengetahuan, dan teknologi.

Sebagian tenaga didik dan tenaga kependidikan sekarang pun sudah sangat mengenal dunia ini. Dengan diterapkan model pembelajaran berbasis multimedia ini akan membantu siswa dan mahasiswa agar lebih melek lagi dengan

135 | Teknologi, Informasi, dan Komunikasi 
dunia informasi teknologi karena tidak semua peserta didik kenal betul dengan dunia ini. Banyaknya harapan yang belum terpenuhi dan tingkat kecemasan yang tinggi, menuntut adanya pembekalan bagi lembaga pendidikan agar terjadi akselerasi ke arah pembelajaran masyarakat. Akselerasi pembelajaran masyarakat tersebut menuntut kesiapan sekolah, baik secara internal maupun eksternal.

Guru diharapkan dapat memanfaatkan ICT secara optimal untuk memfasilitasi aktivitas pembelajaran yang inovatif. Strategi dan metode pembelajaran yang berpusat pada siswa menjadi sangat cocok guna mendorong pengembangan pengetahuan dan skill siswa. Menurut Wagner (2008), dalam dunia global ini siswa tidak cukup dengan hanya mengetahui informasi dan mengingat fakta, tetapi mereka harus bisa berfikir kritis, dan menyelesaikan permasalahan, serta memiliki skill untuk berkomunikasi dan bekerja sama. Disamping itu, siswa harus mampu beradaptasi, mempunyai inisiatif, mampu mengakses dan menganalisis informasi serta mempunyai keingintahuan tinggi menggunakan ICT dan mengintegrasikannya dalam aktivitas pengajaran, guru diharapkan dapat mengantarkan para siswa memenuhi kompetensi tersebut.

Untuk mengoptimalkan kompetensi siswa tersebut diperlukan sistem pembelajaran yang terstruktur dengan baik. Upaya penggabungan model pembelajaran tatap muka di kelas dengan model pembelajaran online ini dikenal dengan istilah blended learning. Tujuan blended learning untuk mendapatkan kualitas pembelajaran yang baik dimana metode pembelajaran tatap muka (face to face) memungkinkan untuk dilakukan pembelajaran interaktif, sedangkan metode online 136 | Teknologi, Informasi, dan Komunikasí 
learning dapat memberikan materi secara online tanpa batas ruang dan waktu, namun masih memungkinkan mendapatkan bimbingan dan arahan untuk dicapai pembelajaran yang maksimal (Hadi, 2012).

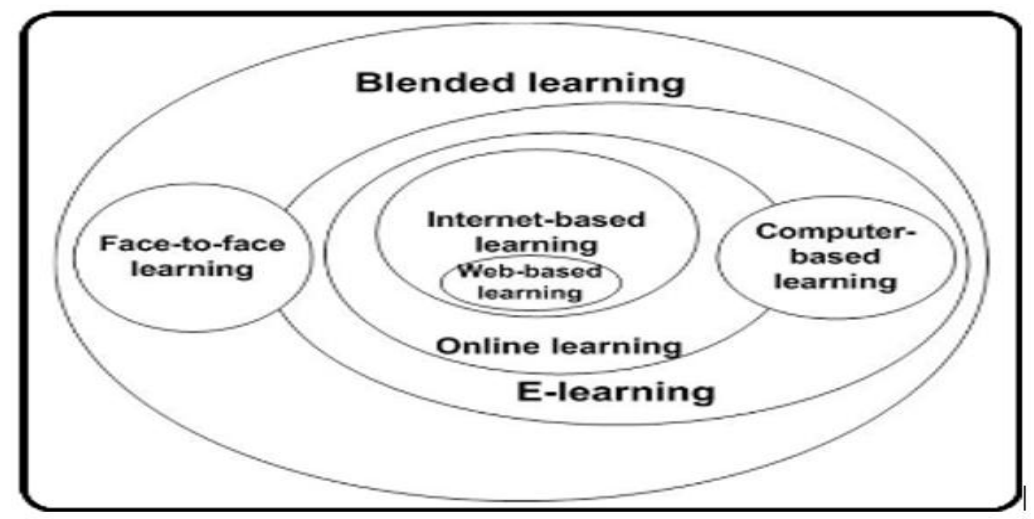

\section{Gambar 35. Siklus blended learning}

Berdasarkan gambar diatas, menunjukkan bahwa terdapat banyak kegiatan dalam pendidikan dan pengajaran yang bisa dilakukan guru dengan bantuan ICT, yaitu diantaranya adalah administrasi, komunikasi, pengembangan sumber belajar, pembuatan rencana pembelajaran, penyampaian bahan ajar, evaluasi, aktivitas dalam dan luar kelas, belajar mandiri, hingga pengembangan profesi guru. Akan tetapi pemanfaatan ICT dalam pembelajaran oleh guru dan siswa secara optimal memang tidaklah mudah. Paling tidak ada tiga kondisi yang harus dipenuhi, yakni: (1) guru dan siswa harus mempunyai akses yang mudah ke perangkat teknologi termasuk koneksi Internet, (2) tersedianya konten digital (bahan ajar) yang mudah dipahami guru dan siswa, (3) guru harus punya pengetahuan dan ketrampilan menggunakan 137 | Teknologi, Informasi, dan Komunikasi 
teknologi dan sumber daya guna membantu siswa mencapai standar akademik.

\section{B. Paradigma Pendidikan Abad-21}

Di abad ke 21 ini, pendidikan menjadi semakin penting untuk menjamin peserta didik memiliki keterampilan belajar dan berinovasi, ketrampilan menggunakan teknologi dan media informasi, serta dapat bekerja, dan bertahan dengan menggunakan keterampilan untuk hidup (life skills). Terkait dengan Paradigma Pendidikan di Abad-21, BNSP merumuskan 16 prinsip pembelajaran yang harus dipenuhi dalam proses pendidikan abad ke-21, yaitu: 1) dari berpusat pada guru menuju berpusat pada siswa; 2) dari satu arah menuju interaktif; 3) dari isolasi menuju lingkungan jejaring; 4) dari pasif menuju aktif menyelidiki; 5) dari maya/abstrak menuju konteks dunia nyata; 6) dari pribadi menuju pembelajaran berbasis tim; 7) dari luas menuju perilaku khas memberdayakan kaidah keterikatan; 8) dari stimulasi rasa tunggal menuju stimulasi ke segala penjuru; 9) dari alat tunggal menuju alat multimedia; 10) dari hubungan satu arah bergeser menuju kooperatif; 11) dari produksi massa menuju kebutuhan pelanggan; 12) dari usaha sadar tunggal menuju jamak; 13) dari satu ilmu dan teknologi bergeser menuju pengetahuan disiplin jamak; 14) dari kontrol terpusat menuju otonomi dan kepercayaan; 15) dari pemikiran faktual menuju kritis, dan; 16) dari penyampaian pengetahuan menuju pertukaran pengetahuan. (BSNP, 2010).

Tiga konsep pendidikan abad 21 telah diadaptasi oleh Kementerian Pendidikan dan Kebudayaan Republik Indonesia untuk mengembangkan kurikulum baru untuk Sekolah Dasar

138 | Teknologi, Informasi, dan Komunikasi 
(SD), Sekolah Menengah Pertama (SMP), Sekolah Menengah Atas (SMA) dan Sekolah Menengah Kejuruan (SMK). Tiga konsep tersebut diadaptasi untuk mengembangkan pendidikan menuju Indonesia Kreatif tahun 2045. Adaptasi dilakukan untuk mencapai kesesuaian konsep kapasitas peserta didik dan kompetensi pendidik dan tenaga kependidikan. Ketiga ketrampilan tersebut dirangkum dalam skema pelangi keterampilan-pengetahuan abad 21 (Trilling dan Fadel, 2009).

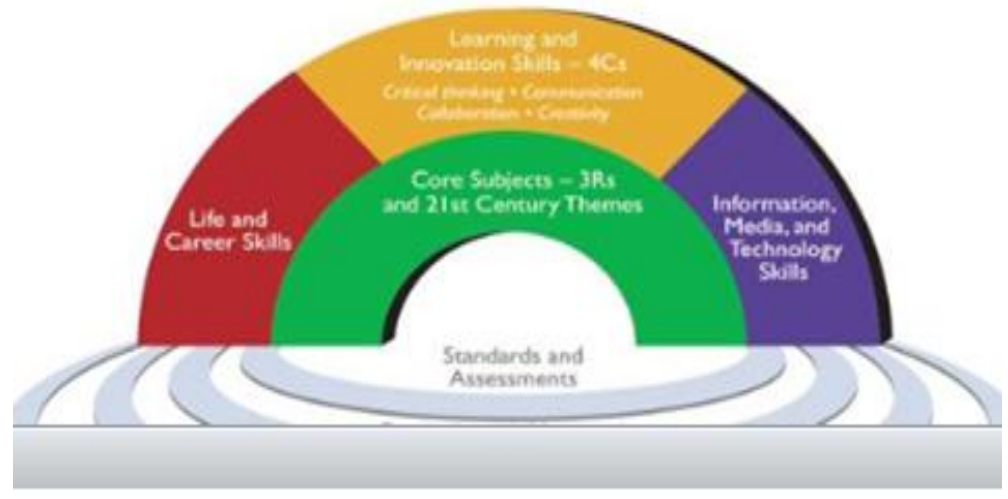

\section{Gambar 36. Ketrampilan pengetahuan Abad 21}

Skema diatas diperjelas dengan tambahan core subject 3R. Dalam konteks pendidikan, 3R adalah singkatan dari reading, writing dan (a) rithmatic, diambil lafal " $\mathrm{R}$ " yang kuat dari setiap kata. Dari subjek reading dan writing, muncul gagasan pendidikan modern yaitu literasi yang digunakan sebagai pembelajaran untuk memahami gagasan melalui media kata-kata. Perkembangan teknologi informasi sudah sedemikian pesatnya, terutama di pusat perkotaan. Seperti kita ketahui bersama adanya kebijakan dalam rangka mengintegrasikan informasi ke dalam pendidikan merupakan suatu terobosan yang diharapkan mampu meningkatkan mutu 139 | Teknologi, Informasi, dan Komunikasi 
pendidikan di Indonesia. Namun, sejauh ini pengembangan teknologi informasi terkonsentrasi di sekolah pusat kota, sedangkan sekolah di pusat desa dan di ujung desa masih sebatas retorika. Walaupun komitmen pemerintah menyatakan akan melakukan kebijakan internet masuk desa.

Kenyataan yang ada saat ini, kita masih mendapati besarnya kesenjangan pendidikan antara sekolah pusat kota, sekolah pinggir kota, dan sekolah pusat desa, serta sekolah di ujung desa. Banyak faktor yang menyebabkan terjadinya kesenjangan ini, salah satunya adalah infrastruktur sekolah yang belum memadai standar, fasilitas perangkat keras dan perangkat lunak teknologi informasi yang belum merata (komputer, jaringan internet, disamping itu distribusi kualifikasi guru dalam memahami dan menguasai teknologi informasi yang belum merata)

Pertukaran informasi menjadi semakin cepat dan instan, namun lembaga pendidikan masih menggunakan sistem tradisional dalam proses pembelajarannya. Sekolah dan perguruan tinggi seharusnya telah meninggalkan sistem tradisional sejak diketemukannya media komunikasi berupa multimedia. Karena sifat teknologi informasi (internet) yang dapat dihubungi setiap saat. Artinya siswa dan mahasiswa dapat memanfaatkan program-program pendidikan yang disediakan di jaringan internet kapan saja sesuai dengan waktu luang mereka sehingga kendala ruang dan waktu yang mereka hadapi untuk mencari sumber belajar dapat teratasi. Dengan perkembangan pesat di bidang teknologi telekomunikasi, multimedia dan informasi maka pembelajaran dengan mendengarkan ceramah, mencatat di atas kertas sudah tentu ketinggalan jaman. Untuk menjawab 140 | Teknologi, Informasi, dan Komunikasi 
tantangan ini diperlukan tenaga pendidik dan tenaga kependidikan yang sesuai dengan kebutuhan dan harapan masyarakat (Mukhtar, 2012).

Perkembangan ICT yang begitu pesat dan kemudahan mengaksesnya mengharuskan guru memanfaatkan berbagai keunggulan ICT tersebut secara inovatif dalam aktivitas pembelajaran baik di dalam maupun di luar kelas. Dengan Perancangan yang baik dan inovatif, ICT Dapat menjadikan materi pembelajaran menjadii lebih menarik, tidak membosankan, mudah dipahami, dan dapat dipelajari kapan saja dan dari mana saja. Blended learning yang merupakan kombinasi ICT (multimedia, e-learning), tatap muka (diskusi, ceramah), dan mandiri (penugasan, Proyek, lab) dirasa bentuk yang paling mungkin diimplementasikan di Indonesia Mengingat masih terbatasnya infrastuktur.

\section{Pembelajaran Berbasis Blended Learning}

E-learning adalah sebuah proses pembelajaran yang berbasis elektronik. Salah satu media yang digunakan adalah jaringan komputer. Sistem e-learning ini tidak memiliki batasan akses. Inilah yang memungkinkan perkuliahan bisa dilakukan lebih banyak waktu, kapanpun mahasiswa bisa mengakses sistem ini. Aktifitas perkuliahan ditawarkan untuk bisa melayani seperti perkuliahan biasa. Ada penyampaian materi berbentuk teks maupun hasil penyimpanan suara yang bisa di download, selain itu juga ada forum diskusi, bisa juga seorang dosen memberikan nilai, tugas dan pengumuman kepada mahasiswa.

141 |Teknologi, Informasi, dan Komuníkasi 
Jika dikaji secara terminologis maka blended $e$ learning menekankan pada penggunaan internet seperti pendapat Rosenberg (2001) bahwa blended e-learning merujuk pada penggunaan teknologi internet untuk mengirimkan serangkaian solusi yang dapat meningkatkan pengetahuan dan keterampilan. Hal ini senada dengan Campbell (2002) dan Kamarga (2002) yang intinya menekankan penggunaan internet dalam pendidikan sebagai hakikat blended e-learning, termasuk untuk pendidikan guru/dosen. Blended learning telah didefinisikan oleh Ciso Sistem (dalam Rusman, 2011:244) yaitu:

As the combition of the characteristic from both traditional learning and blended e-learning environment. It merges aspects of blended e-learning as such as: web based instruction, streaming video, audio synchronous and asynchronous communication, etc: with traditional "face to face learning" learning.

Blended learning merupakan istilah yang berasal dari bahasa inggris, yang terdiri dari dua suku kata, blended dan learning. Blended merupakan campuran, kombinasi yang baik. Sedangkan learning memiliki makna umum belajar, dengan demikian sepintas mengandung makna pola pembelajaran yang mengandung unsur pencampuran, atau penggabungan antara satu pola dengan pola yang lainnya. Berikut ini pengertian blended learning dari beberapa sumber.

1) Thorne (2003), Blended learning adalah perpaduan dari teknologi multimedia, CD ROM, video streaming, kelas virtual, voicemail, email dan telefon conference, animasi

142 | Teknologi, informasi, dan Komunikasi 
teks online dan video-streaming. Semua ini dikombinasi dengan bentuk tradisional pelatihan di kelas. Blended learning menjadi solusi yang paling tepat untuk proses pembelajaran yang sesuai tidak hanya dengan kebutuhan pembelajaran akan tetapi juga gaya si pembelajar.

2) Harding, Kaczynski dan Wood (2005), Blended learning merupakan pendekatan pembelajaran yang mengintegrasikan pembelajaran tradisonal tatap muka dan pembelajaran jarak jauh yang menggunakan sumber belajar online dan beragam pilihan komunikasi yang dapat digunakan oleh guru dan siswa Pelaksanaan pendekatan ini memungkinkan penggunaan sumber belajar online, terutama yang berbasis web, dengan tanpa meninggalkan kegiatan tatap muka.

3) Wilson \& Smilanich (2005) menyimpulkan bahwa Blended learning adalah penggunaan solusi pelatihan yang paling efektif, diterapkan dalam cara yang terkoordinasi untuk mencapai tujuan pembelajaran yang diinginkan.

4) MacDonald (2008), istilah blended learning biasanya berasosiasi dengan memasukkan media online pada program pembelajaran, sementara pada saat yang sama tetap mempertahankan kontak tatap muka dan pendekatan tradisional yang lain untuk mendukung siswa. Istilah ini juga digunakan pada media asynchronous seperti email, forum, blogs atau wikis digabungkan dengan teknologi, teks atau audio sinkronus.

Penerapan blended learning tidak terjadi secara begitu saja. Tapi, terlebih dulu harus ada pertimbangan karakteristik 143 | Teknologi, Informasi, dan Komunikasi 
tujuan pembelajaran yang ingin kita capai, aktifitas pembelajaran yang relevan serta memilih dan menentukan aktifitas mana yang relevan dengan konvensional dan aktifitas mana yang relevan untuk online learning. Tujuan dari blended learning adalah untuk mendapatkan pembelajaran yang baik dimana metode pembelajaran tatap muka memungkinkan untuk melaksanakan pembelajaran secara interaktif, sedangkan metode pembelajaran online dapat memberikan materi secara online tanpa batasan ruang dan waktu sehingga dapat dicapai pembelajaran yang maksimal. Tidak ada aturan baku tentang pembelajaran secara blended, oleh karena itu dapat disesuaikan dengan kebutuhan yang ada. Dalam penelitian ini ditentukan blended learning yang digunakan adalah kombinasi pembelajaran tatap muka dan pembelajaran online.

Blended learning diwujudkan dalam lingkungan belajar mengajar terdapat integrasi dari berbagai modus pengiriman, model pengajaran dan gaya belajar sebagai hasil dari strategis dan pendekatan sistematis penggunaan teknologi yang dikombinasikan dengan interaksi dalam model tatap muka. (Debra Bath and John Bourke: 2013). Blended learning terbukti efektif mengintegrasikan TIK ke dalam desain pengajaran dan pembelajaran. Dalam banyak kasus "blending" efisien sebagai desain pengajaran dan pembelajaran untuk memberikan pengalaman yang lebih baik bagi siswa. Hal ini dikarenakan blending dapat melibatkan campuran model pengiriman, pendekatan dan gaya belajar siswa. Kemajuan teknologi memberikan peluang untuk guru dalam merancang dan meningkatkan perannya dan siswa

144 |Teknologi, Informasi, dan Komunikasi 
memperoleh pengalaman kognitif melalui lingkungan belajarnya.

Mengajar atau "teaching" adalah membantu peserta didik memperoleh informasi, ide, keterampilan, nilai, cara berpikir, sarana untuk mengekspresikan dirinya, dan cara-cara belajar bagaimana belajar (Joyce dan Well, 1996). Sedangkan pembelajaran adalah upaya untuk membelajarkan peserta didik. Secara implisit dalam pembelajaran terdapat kegiatan memilih, menetapkan mengembangkan metode untuk mencapai hasil pembelajaran yang diinginkan. Pemilihan, penetapan, dan pengembangan metode didasarkan pada kondisi pembelajaran yang ada. Kegiatan-kegiatan tersebut pada dasarnya merupakan inti dari perencanaan pembelajaran. Konsep pembelajaran adalah "bagaimana membelajarkan peserta didik", dan bukan pada "apa yang dipelajari peserta didik". Dengan demikian pembelajaran menempatkan peserta didik sebagai subjek bukan sebagai objek. Oleh karena itu agar pembelajaran dapat mencapai hasil yang optimal guru perlu memahami karakteristik peserta didik.

\section{Mengembangkan Kecakapan Siswa}

Sekurang-kurangnya terdapat dua macam kecakapan kognitif siswa yang penting dikembangkan oleh seorang pendidik terhadap siswanya, yakni; 1) strategi belajar memahami isi materi pelajaran, 2) strategi memahami arti penting isi materi pelajaran dan aplikasinya serta menyerap pesan-pesan moral yang terkandung dalam materi pelajaran tersebut. Tanpa pengembangan dua macam kecakapan kognitif ini, agaknya siswa sulit diharapkan mampu 
mengembangkan ranah afektif dan psikomotornya sendiri (Muhibbinsyah, 2010).

Siswa dengan menggunakan perangkat Teknologi Informasi dan Komunikasi untuk mencari, mengeksplorasi, menganalisis, dan saling tukar informasi secara kreatif dan bertanggungjawab. Penggunaan Teknologi Informasi dan Komunikasi akan mengembangkan sikap inisiatif dan kemampuan belajar mandiri. Pada kondisi yang demikian siswa memiliki inisiatif sendiri dan motivasi intrinsik, menganalisis kebutuhan dan merumuskan tujuan, memilih dan menerapkan strategi penyelesaian masalah, memilih sumber belajar yang sesuai, serta mengevaluasi diri terhadap performansinya.

Pengaturan diri siswa dalam belajar digambarkan sebagai derajat tingkatan secara metakognitif, secara motivasional, dan secara perilaku berperan aktif dalam belajar siswa sendiri (Zimmerman, 1989). Siswa memiliki kemampuan mengatur diri (self-regulated) menerapkan berbagai strategi kognitif dan metakognitif untuk mencapai tujuan belajar (Corno \& Mandinach, 1983). Siswa juga menerapkan strategi manajemen sumber daya untuk memilih atau mengatur aspek lingkungan fisik untuk mendukung belajar mereka dan untuk mengatur waktu mereka secara efektif. Sebagai tambahan, mereka lebih mungkin mencari teman sebaya atau bantuan guru jika mereka menemukan kesulitan belajar.

Kaitan antara pengaturan diri dalam belajar dan penggunaan ICT dalam pembelajaran, sangat ditentukan oleh faktor kemandirian dalam kegiatan belajar, sehingga guru tidak lagi bertindak sebagai pemberi pengetahuan melainkan 146 | Teknologi, Informasi, dan Komunikasi 
sebagai fasilitator. Dalam hal ini siswa dapat menentukan sendiri apa yang akan dipelajarinya dan kapan mereka akan mempelajarinya secara mendalam. Merekapun diberi kebebasan untuk membuat kesimpulan/intisari dari apa yang telah dipelajarinya.

Bahasan tentang teknologi, tak lepas dari kemajuan Teknologi Informasi dan Komunikasi (TIK) dan berbagai kemungkinan penerapannya, khususnya pada pembelajaran. Kekuatan TIK pada pembelajaran, akan melahirkan konsep $e$ learning, manfaat e-learning, dan bahan-bahan pembelajaran untuk e-learning. E-learning termasuk model pembelajaran yang berpusat pada peserta didik. Dengan model pembelajaran ini, peserta didik dituntut mandiri dan bertanggung jawab terhadap proses pembelajarannya, sebab ia dapat belajar di mana saja, kapan saja, yang penting tersedia alatnya. E-learning menuntut keaktifan peserta didik. Peserta didik akan memiliki kekayaan informasi, sebab ia dapat mengakses informasi dari mana saja yang berhubungan dengan materi pembelajarannya.

Model pengembangan TIK dalam pembelajaran dapat dilakukan dalam empat tahapan, yaitu emerging, applying, infusing, dan transforming (Majumdar dalam Budi Murtiyasa (2012). Emerging adalah tahap dimana semua insan pendidikan menjadi memiliki perhatian terhadap TIK. Hal ini ditandai dengan kebutuhan akan dukungan terhadap performa kerja. Applying adalah tahapan dimana para insan pendidikan mulai belajar menggunakan TIK. Pada tahapan ini kebutuhan untuk meningkatkan kualitas pembelajaran tradisional dengan TIK mulai dirasakan sebagai suatu kebutuhan. Infusing adalah tahap dimana para insan pendidikan mulai mengetahui 147 | Teknologi, Informasi, dan Komunikasí 
bagaimana dan kapan menggunakan TIK. Ini ditunjukkan dengan kemampuan menyediakan fasilitas belajar berbasis TIK bagi para peserta didik Akhirnya tahap transforming adalah secara spesifik dapat menggunakan TIK untuk membantu menyelesaikan tugas-tugas pembelajaran yang dihadapinya. Dengan TIK dapat diciptakan lingkungan belajar yang inovatif, sehingga merangsang peserta didik untuk berpikir dan berkreasi untuk memecahkan masalah.

Keberhasilan pengembangan ranah kognitif tidak hanya akan membuahkan hasil pada kecakapan kognitif saja, melainkan dapat menghasilkan kecakapan ranah afektif. Sebagai contoh seorang guru agama yang piawai dalam mengembangkan kecakapan kognitif dengan cara akan berdampak positif terhadap ranah afektif para siswa. Dalam hal ini, pemahaman yang mendalam terhadap arti penting materi pelajaran agama yang disajikan guru serta preferensi kognitif yang mementingkan kecakapan ranah afektif para siswa. Ranah afektif berkenaan dengan sikap dan nilai dalam berbagai tingkah laku seperti perhatiaannya terhadap pelajaran, disiplin, motivasi belajar, menghargai guru, kebiasaan belajar, dan hubungan sosial.

Perkembangan teknologi informasi dan komunikasi (TIK) telah memberikan pengaruh terhadap dunia pendidikan khususnya dalam proses pembelajaran. Komunikasi sebagai media pendidikan dilakukan dengan menggunakan mediamedia komunikasi seperti telepon, komputer, internet, e-mail, dsb. Interaksi antara guru dan siswa tidak hanya dilakukan melalui hubungan tatap muka tetapi juga dilakukan dengan menggunakan media-media tersebut.

148 | Teknologi, Informasi, dan Komunikasi 
Guru dapat memberikan layanan tanpa harus berhadapan langsung dengan siswa. Penggunaan komputer dalam pendidikan dapat menggabungkan unsur inovasi, kreativitas dan hiburan, menjadikan peserta didik memiliki rasa senang, tidak jenuh menerima pelajaran dan memudahkan tenaga pendidik dalam mempersiapkan materi pembelajaran. Apabila media teknologi ini tersedia, maka dengan mudah siswa dapat memfokuskan pengambilan keputusan, refleksi, penalaran, dan problem solving. Hal ini akan mendorong daya pikir kritis siswa dan berkeasi dengan bebas. Keberhasilan pengembangan ranah kognitif juga akan berdampak positif pada perkembangan ranah psikomotor. Kecakapan psikomotor adalah segala amal jasmaniah yang konkret dan mudah diamati, baik kuantitasnya maupun kualitasnya, karena sifatnya yang terbuka. Namun kecakapan psikomotor tidak terlepas dari kecakapan afektif. Jadi, kecakapan psikomotor siswa merupakan manifestasi wawasan pengetahuan dan kesadaran serta sikap mentalnya.

\section{E. Pembelajaran Berbasis Teknologi Informasi}

Sejarah Teknologi Informasi dan Komunikasi, TIK (bahasa Inggris: Information and Communication Technologies /ICT). TIK mencakup dua aspek yaitu teknologi informasi dan teknologi komunikasi. Teknologi informasi meliputi segala hal yang berkaitan dengan proses, penggunaan sebagai alat bantu, manipulasi, dan pengelolaan informasi. Sedangkan teknologi komunikasi adalah segala sesuatu yang berkaitan dengan penggunaan alat bantu untuk memproses dan mentransfer data dari perangkat yang satu ke lainnya. Oleh karena itu, teknologi informasi dan teknologi

149 | Teknologi, Informasi, dan Komunikasi 
komunikasi adalah dua buah konsep yang tidak terpisahkan. Jadi Teknologi Informasi dan Komunikasi mengandung pengertian luas yaitu segala kegiatan yang terkait dengan pemrosesan, manipulasi, pengelolaan, pemindahan informasi antar media.

Pengertian Teknologi Informasi dan Komunikasi, adalah suatu teknologi yang digunakan untuk mengolah data, termasuk memproses, mendapatkan, menyusun, menyimpan, memanipulasi data dalam berbagai cara untuk menghasilkan informasi yang berkualitas, yaitu informasi yang relevan, akurat dan tepat waktu, yang digunakan untuk keperluan pribadi, bisnis, dan pemerintahan dan merupakan informasi yang strategis untuk pengambilan keputusan. Teknologi ini menggunakan seperangkat komputer untuk mengolah data, sistem jaringan untuk menghubungkan satu komputer dengan komputer yang lainnya sesuai dengan kebutuhan, dan teknologi telekomunikasi digunakan agar data dapat disebar dan diakses secara global. Pemanfaatan teknologi informasi dalam bidang pendidikan merupakan kelaziman untuk membantu menyediakan komputer dan jaringan yang menghubungkan rumah siswa dengan ruang kelas, guru, dan administrator sekolah. Semuanya dihubungkan ke Internet, dan para guru dilatih menggunakan komputer pribadi.

Menghadapi era globalisasi dan kompetisi sebagai konsekuensi tak terhindarkan dari proses itu menuntut peningkatan dan pengembangan kualitas sumber daya manusia (SDM). Persaingan era global telah dipenuhi segala teknologi canggih. Kita tahu bahwa kemajuan pendidikan step by step, sedangkan lajunya perkembangan teknologi jump by jump. Hamper semua bidang pendidikan harus bisa 150 | Teknologi, informasi, dan Komunikasi 
memberdayakan dan memanfaatkan kemajuan teknologi dalam upaya menghasilkan SDM yang berkualitas dan mampu bersaing dalam pencaturan global.

Fenomena globalisasi yang ditandai dengan kekuatan konvergensi teknologi informasi dan komunikasi (TIK) mestinya dijadikan faktor mendasar untuk menstranformasikan lembaga pendidikan. Pentingnya lembaga pendidikan membangun sistem yang emndukung terwujudnya lingkungan pembelajaran generasi baru alias Next Generation Learning Environment, yaitu dengan cara pemanfaatan teknologi TIK terkini untuk meningkatkan kualitas pembelajaran, adminisrasi serta interaksi dan kolaborasi antar guru, siswa, orang tua, komunitas dan sekolah yang lebih efektif dan murah.

Tugas yang besar bagi lembaga pendidikan di Indonesia untuk melakukan upaya-upaya terobosan dan progresif untuk meningkatkan kualitas tersebut. Sebab jika tidak, maka pengembangan SDM bangsa ini akan terus tertinggal. Kepentingan in I semakin mendesak mengingat dalam waktu yang tidak lama lagi, institusi pendidikan dari luar negeri dimungkinkan untuk diselenggarakan di Indonesia. Hal ini merupakan tantangan besar bagi institusi pendidikan dalam negeri untuk segera berbenah. Perkembangan teknologi informasi telah mengarah ke teknologi Web yang ditandai dengan berkembangnya sistem berbasis jejaring social (social networking) juga diwarnai teknologi yang memungkinkan berjalannya aplikasi web seperti aplikasi desktop, berkembnagnya teknologi multimedia baik audio dan video streaming dan lain sebagainya.

151 | Teknologi, Informasi, dan Komunikasi 
Pemanfaatan teknologi informasi dalam bidang pendidikan sudah merupakan suatu keharusan untuk memfasilitasi dan mempermudah proses pembelajaran. Seperti menggunakan komputer atau notebook/netbook, liquid, crystal display (LCD), interconnection-networking (internet), Compact Disk (CD), flasdisk, dimana pemanfaatannya tersebut dapat membantu proses kegiatan belajar mengajar. Kemajuan teknologi informasi memang membawa dampak positif bagi dunia pendidikan. Teknologi informasi khususnya teknologi komputer dan internet, baik dalam hal perangkat keras maupun lunaknya, memberikan banyak tawaran dan pilihan bagi dunia pendidikan untuk menunjang proses pembelajaran peserta didik. Keunggulan yang ditawarkan bukan saja terletak pada faktor kecepatan untuk mendapatkan informasi namun juga fasilitas multimedia yang dapat membuat belajar lebih menarik, visual dan interaktif.

Sejalan dengan perkembangan teknologi internet banyak kegiatan pembelajaran yang dapat dilakukan dengan memanfaatkan teknologi ini. Untuk selanjutnya pembelajaran melalui jalur internet kita sebut sebagai pembelajaran berbasis web. Harus diakui bahwa pembelajaran berbasis web ini dapat terlaksana karena pengembangan yang pesat di tiga bidang yaitu bidang pembelajaran jarak jauh, pembelajaran dengan menggunakan teknlogi komputer dan perkembangan yang sangat pesat dalam teknologi internet.

Pembelajaran jarak jauh mempunyai sejarah yang sudah sangat lama. Pembelajaran jarak jauh dimulai dan dikenal masyarakat dunia sekitar pertengahan tahun 1800-an di Amerika Serikat, Perancis dan beberapa negara Eropa 152 | Teknologi, Informasi, dan Komunikasi 
lainnya (Moore \& Kearsley, 1996). Pada umumnya pembelajaran jarak jauh dilakukan melalui korespondensi menggunakan media kertas dan jasa pos. Namun kemudian kemajuan teknologi komputer berkembang sangat pesat dan ini membawa dampak luar biasa dalam memberikan kesempatan bagi siapa saja untuk mengakses informasi untuk pembelajaran dengan lebih mudah, menarik, visual dan interaktif.

Berbagai istilah pembelajaran dengan memanfaatkan komputer mulai dari komputer-aided instruction (CAI), komputer based training (CBT) sudah tidak asing lagi di telinga kita. Sedangkan pembelajaran berbasis web mulai digunakan setelah teknologi internet berkembang pesat. Melalui internet banyak informasi yang dapat diakses oleh siapa saja, kapan saja dan di mana saja. Pengaksesan informasi menjadi relatif lebih cepat, murah dan mudah. Teknologi internet memberikan kemudahan bagi siapa saja untuk mendapatkan informasi apa saja dari mana saja dan kapan saja dengan mudah dan cepat. Informasi yang tersedia di berbagai pusat data di berbagai komputer di dunia, selama komputer-komputer tersebut saling terhubung dalam jaringan internet, dapat kita akses dari mana saja. Ini merupakan salah satu keuntungan belajar melalui media internet.

\section{F. Pembelajaran Secara Tatap Muka dan Virtual}

Sekalipun teknologi web memungkinkan pembelajaran dilakukan virtual secara penuh namun kesempatan itu tidak dapat dilakukan. Interaksi selama pembelajaran secara tatap muka masih tetap dibutuhkan. Ada tiga alasan mengapa forum tatap muka masih dibutuhkan

153 | Teknologi, Informasi, dan Komunikasi 
dalam kegiatan pembelajaran ini. Tiga alasan tersebut adalah: 1) perlunya forum untuk menjelaskan maksud dan mekanisme belajar yang akan dilalui bersama secara langsung dengan semua peserta didik, 2) perlunya memberikan pemahaman sekaligus pengalaman belajar dengan mengerjakan tugas secara kelompok dan kolaboratif pada setiap peserta didik. Karena model pembelajaran yang dirancang menuntut kerja kelompok maka peserta didik perlu memiliki kompetensi dalam berkomunikasi, 3) perlunya memberikan pelatihan menggunakan komputer yang akan digunakan sebagai media komunikasi berbasis web kepada setiap peserta didik.

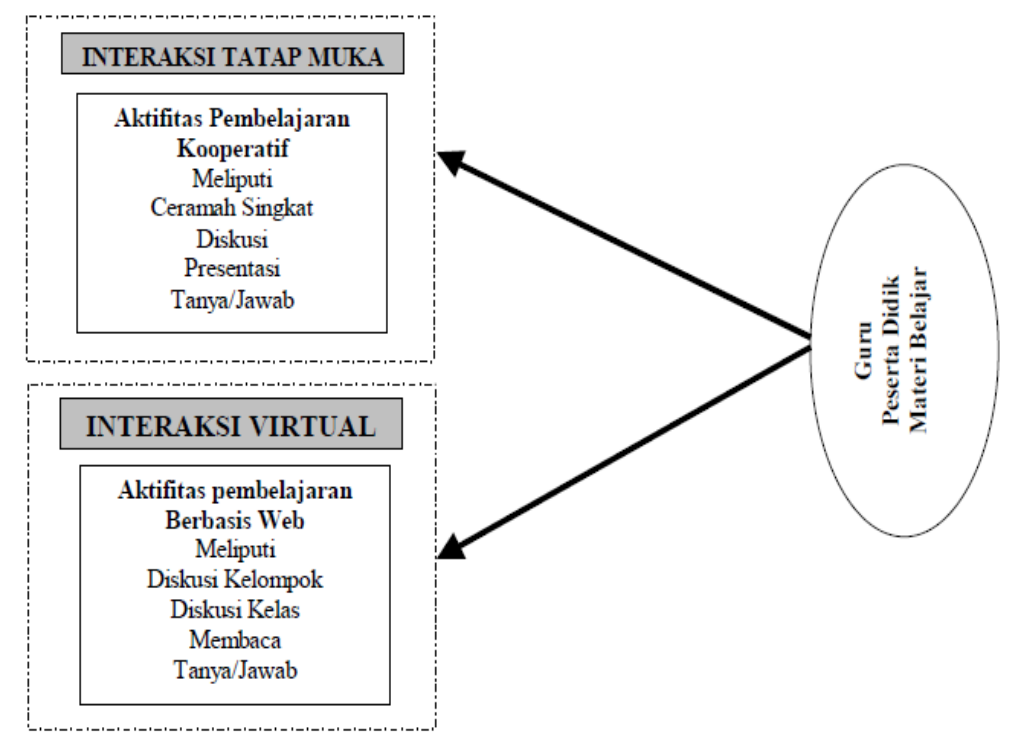

\section{Gambar 37. Aktifitas Pembelajaran Berbasis Virtual dan Tatap Muka}

154 | Teknologi, Informasi, dan Komunikasi 
Pada sesi tatap muka guru menyampaikan pokokpokok bahasan penting. Ceramah singkat dengan mengundang peserta didik untuk berpartisipasi langsung dalam diskusi sangat baik untuk dilakukan. Ini tentu saja membangun iklim partisipatoris dalam kelas. Mengerjakan tugas dalam kelompok maupun pribadi diberikan untuk melatih diri bekerja dalam kelompok. Sikap terbuka dan berani berekspresi merupakan sikap dasar dan penting yang dibutuhkan pada sesi diskusi virtual berikutnya.

Interaksi secara virtual dilakukan untuk mendiskusikan topik-topik penting untuk dipahami bersamasama. Mereka diharapkan untuk saling menyampaikan pikiran maupun mengkritisi pendapat lain atas sebuah topik yang telah ditentukan oleh guru maupun dipilih oleh mereka sendiri. Kerja dalam kelompok dan kolaborasi dilakukan melalui media atau forum khusus didedikasikan untuk masing-masing kelompok virtual yang ada. Forum diskusi tersebut dinamakan konferensi. Konferensi yang digunakan oleh setiap kelompok bersifat tertutup (private conference), artinya konferensi tersebut hanya dapat diakses oleh anggota kelompok itu saja dan guru (jika dikehendaki). Namun di samping itu, antar sesama peserta didik berbeda kelompok juga dapat saling berkomunikasi melalui sebuah konferensi kelas yang bersifat terbuka (opened conference).

Semua peserta didik dapat mengakses konferensi terbuka ini tidak bergantung kelompok apa dia berasal. Ini sengaja dibuat dengan maksud agar setiap temuan, hasil kerja kelompok juga dapat dibagikan kepada kelompok lain. Kelompok lain dapat memberikan pendapat dan kritik atas pendapat kelompok lain melalui konferensi ini.

155 | Teknologi, informasi, dan Komuníkasí 


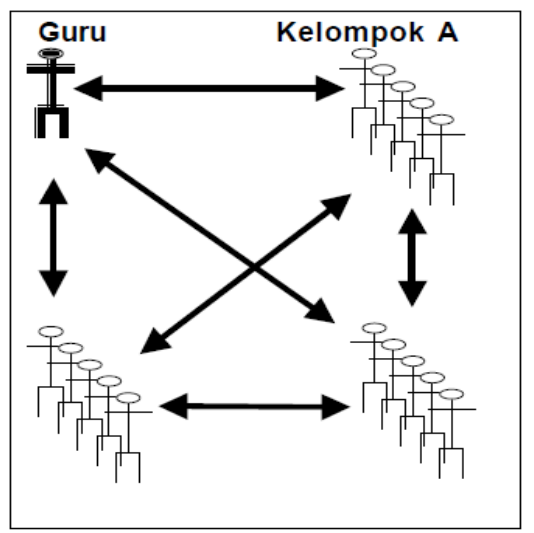

Kelompok B Kelompok C

(a)

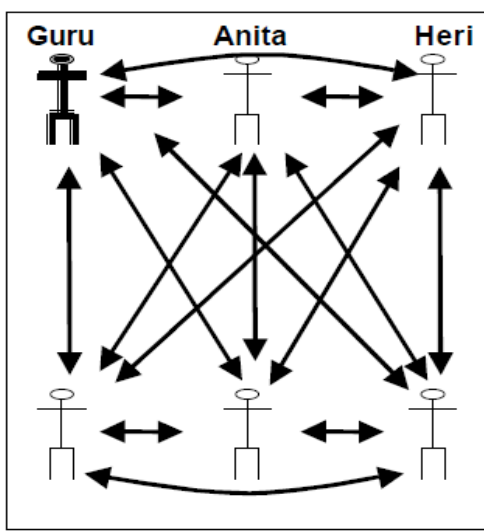

Dedi Linda

Kiki

(b)

\section{Gambar 38. Komunikasi antar peserta pada diskusi virtual}

Model jalur komunikasi dalam kerja kelompok dan kolaborasi dapat dilihat pada gambar 38. Diskusi dilakukan antar kelompok dan pihak guru (gambar 3a) maupun antar individu peserta didik dan guru (gambar 38). Penugasan atas nama kelompok didiskusikan antar anggota kelompok tersebut untuk kemudian disampaikan kepada kelompok lain. Selain diskusi, seseorang dapat menyampaikan pertanyaan kepada guru atau kepada sesama peserta didik. Semangat belajar dari dan untuk sesama merupakan warna kegiatan pendidikan ini.

\section{G. Kompetensi Profesi Guru berbasis ICT}

Berdasarkan definisi yang diberikan oleh UNESCO Asia and Pacific Regional Bureau for Education and Commonwealth of Learning, bahwa TIK adalah teknologi yang digunakan untuk berkomunikasi dan untuk membuat, 156 | Teknologi, Informasi, dan Komuníkasí 
mengelola dan mendistribusikan informasi. Dari definisi yang luas, TIK termasuk komputer, internet, telepon, televisi, radio, dan peralatan audiovisual (UNESCO, 2008). Bondan S. Prakoso dan Rakhmat Januardy (2005) mengemukakan bahwa program TIK di lingkungan Kemendikbud dirancang, disusun, dan dilaksanakan agar dapat memberikan sebesarbesarnya manfaat bagi semua pihak, khususnya komunitas.

Banyak perubahan yang terjadi dalam pendidikan, dimana TIK merupakan salah satu kekuatan pendorongnya. Salah satu bentuk perubahan itu adalah meningkatnya akses ke TIK di kalangan siswa dan guru baik di rumah maupun di sekolah, tak terkecuali di Indonesia. Sebagaimana yang dilansir oleh Communication and Information Unit UNESCO Bangkok bahwa penggunaan TIK di lingkungan pendidikan di Indonesia yang telah teridentifikasi, yaitu: (1) penggunaan TIK yang paling dominan adalah untuk email; (2) TIK dimasukkan dalam kurikulum di beberapa sekolah; (3) pusat pelatihan swasta menawarkan kursus singkat terkait TIK (misalnya, MS Office, Desain web , animasi); (4) anggaran telah dialokasikan untuk fasilitas TIK dan koneksi internet di sekolah; dan (5) pelatihan komputer dasar disediakan untuk guru.

Keterampilan TIK adalah kompetensi pada bidang pembelajaran, yang mencerminkan pemerataan yang luas dalam keterampilan penggunaan TIK. Keterampilan TIK di adaptasi, ditransfer, dan digunakan sebagai alat untuk membantu transformasi pembelajaran dalam hubungannya dengan keterampilan penting lainnya seperti membaca, berhitung dan pemecahan masalah (Mceetya, 2005). Hal senada dikemukakan oleh CETF bahwa keterampilan 157 | Teknologi, Informasi, dan Komunikasí 
TIK/digital adalah kemampuan untuk menggunakan peralatan komunikasi dan teknologi digital dan atau jaringan untuk mengakses, mengelola, mengintegrasikan, mengevaluasi, membuat dan mengkomunikasikan informasi sesuai fungsi nya dalam masyarakat berpengetahuan.

Dalam konteks Indonesia, UNESCO mengemukakan bahwa pada sejumlah sekolah di Indonesia TIK telah digunakan secara terpadu dalam pendidikan. Guru yang mempunyai kompetensi TIK ditunjuk sebagai koordinator TIK, yang bertanggung jawab atas pengelolaan penggunaan TIK di sekolah. Realitas yang ada adalah kebanyakan koordinator TIK tidak memiliki latar belakang pendidikan TIK. Oleh karena itu, melatih mereka dalam TIK yang berhubungan dengan keterampilan yang diperlukan. JIS (Jaringan Informasi Sekolah), sebuah program diprakarsai oleh Direktorat PSMK, bertujuan untuk memberikan pelatihan TIK bagi guru dalam jaringan.

Sebagaimana dikemukakan oleh Pelgrum, bahwa hasil survey yang dilakukan terhadap sekolah di 24 negara menunjukkan hambatan serius yang dirasakan oleh praktisi pendidikan dalam upaya mewujudkan tujuan mereka terkait TIK, antara lain:1) kurangnya jumlah komputer; (2) guru tidak memiliki pengetahuan/keterampilan; (3) kesulitan untuk mengintegrasikan dalam pembelajaran;(4) supervisi dari staf tidak cukup; dan (5) tidak cukup kesempatan mengikuti pelatihan.

158 | Teknologi, informasi, dan Komunikasi 


\section{Rangkuman dan Soal}

1. E-learning adalah sebuah proses pembelajaran yang berbasis elektronik. Salah satu media yang digunakan adalah jaringan komputer. Sistem e-learning ini tidak memiliki batasan akses. Inilah yang memungkinkan perkuliahan bisa dilakukan lebih banyak waktu, kapanpun mahasiswa bisa mengakses sistem ini.

2. Pelaksanaan blended learning bertujuan untuk mendapatkan kualitas pembelajaran yang baik dimana metode pembelajaran tatap muka (face to face) memungkinkan untuk dilakukan pembelajaran interaktif, sedangkan metode online learning dapat memberikan materi secara online tanpa batas ruang dan waktu, namun masih memungkinkan mendapatkan bimbingan dan arahan untuk dicapai pembelajaran yang maksimal

3. Keterampilan TIK adalah kompetensi pada bidang pembelajaran, yang mencerminkan pemerataan yang luas dalam keterampilan penggunaan TIK. Keterampilan TIK di adaptasi, ditransfer, dan digunakan sebagai alat untuk membantu transformasi pembelajaran dalam hubungannya dengan keterampilan penting lainnya seperti membaca, berhitung dan pemecahan masalah

4. Paradigma Pendidikan di Abad-21 merumuskan 16 prinsip pembelajaran yang harus dipenuhi dalam proses pendidikan, yaitu: 1) dari berpusat pada guru menuju berpusat pada siswa; 2) dari satu arah menuju interaktif; 3) dari isolasi menuju lingkungan jejaring; 4) dari pasif 
menuju aktif menyelidiki; 5) dari maya/abstrak menuju konteks dunia nyata; 6) dari pribadi menuju pembelajaran berbasis tim; 7) dari luas menuju perilaku khas memberdayakan kaidah keterikatan; 8) dari stimulasi rasa tunggal menuju stimulasi ke segala penjuru; 9) dari alat tunggal menuju alat multimedia; 10) dari hubungan satu arah bergeser menuju kooperatif; 11) dari produksi massa menuju kebutuhan pelanggan; 12) dari usaha sadar tunggal menuju jamak; 13) dari satu ilmu dan teknologi bergeser menuju pengetahuan disiplin jamak; 14) dari kontrol terpusat menuju otonomi dan kepercayaan; 15) dari pemikiran faktual menuju kritis, dan; 16) dari penyampaian pengetahuan menuju pertukaran pengetahuan

\section{Latihan Soal}

1. Jelaskan apa yang dimaksud e-learning dan bagaimana aplikasi pembelajarannya dapat diterapkan?

2. Sebutkan dan jelaskan perbedaan blended learning dan elearning dari segi makna maupun implementasinya?

3. Paradigma pendidikan abad 21, memfokuskan pada ketrampilan individu dalam hal penguasaan teknologi, informasi, dan komunikasi, jelaskan ketrampilan TIK yang dimaksud?

4. Sebutkan dan jelaskan 16 prinsip pembelajaran abad 21 dalam proses pendidikan? 


\section{DAFTAR PUSTAKA}

Azhar Arsyad. 2005. Media Pembelajaran. Jakarta: Raja Grafindo Persada

Agustiani Hendriati. 2009. Psikologi Perkembangan. Bandung. PT Refika Aditama

Alfian. 2010. Membuat Presentasi Menakjubkan dengan Microsoft Power Point. Mediakita.

Arends. 1997. Classroom Instructional and Management. The McGraw-Hill Companies, Inc.

Atang Gumawang. 2007. Belajar Otodidak Word, Excel, Power Point XP. (Cetakan ke-20). Bandung: Informatika.Bandung.

Banks, Teresa. 2000. "Teaching Learning Process: Assess, Plan, Implement, Evaluate, Document". Journal of Research in Science Teaching.

Benyamin S. 1979. Taksonomy Of Educational Objectives (The Clasification of Educational Goals). Handbook I Cognitive Domain. London: Longman Group Ltd

Budi Murtiyasa. 2012. Pemanfaatan Teknologi Informasi dan Komunikasi Untuk Meningkatkan Kualitas Pembelajaran Matematika. Surakarta : FKIP Univ. Muhammadiyah Surakarta.

Line].http://physicsmaster.orgfree.com/Artikel\%20\&\%20 Jurnal/Inovasi\%20

Dalam\%20Pendidikan /TIK_inEduMath.pdf

Budiman.2003. Etika Profesi Guru. Yogyakarta: Mentari Pustaka

161 | Teknologi, Informasi, dan Komunikasi 
Daniel J. 2012. ICT dan Pembelajaran (Kurikulum untuk Sekolah dan Program Pengembangan Guru), terjemahan dari Information and Communication Technology in Education (A Curriculum for Schoolsand Programme of Teacher Development). Jakarta : Referensi.

Danim S. 2010. Media komunikasi pendidikan. Jakarta : PT. Bumi Aksara. Cet. 3.

Daradjat, Zakiah. 1991. Ilmu Pendidikan Islam. Jakarta: Penerbit Bumi Angkasa

Departemen Pendidikan Nasional. 2003. Undang-Undang Republik Indonesia Nomor 20 Tahun 2003 Tentang Sistem Pendidikan Nasional. Bandung: Citra Umbara

Dick, W.and Carey, L. 1996. The sistematic Desaign Intruksional. New York: Longman.Dimyati dan Mudjiono, (2009), Belajar dan Pembelajaran, Jakarta: Rineka Cipta.

Djamaroh, Syaiful Bahri. 2001. Guru dan Anak Didik dalam Interaksi Edukatif. Jakarta: Rineka Cipta

Golu, W. 2002. Strategi Belajar Mengajar. Jakarta: Grasindo

Hamalik, Oemar. 2011. Proses belajar mengajar. Jakarta : Bumi Aksara

Hanafiah, Nanang, dkk. 2010. Konsep Strategi Pembelajaran. Bandung: PT Refika Aditama

Jhonson, B. 2002 Contextual Teaching Learning.Terjemahan oleh Ibnu Setiawan dan Ida Sitompul. 2007. Bandung: Mizan Learning Centre.

Joyce, B. dan Weil, M. 1996. Model Of Teaching. Englewood Cliffs, New Jersey: Prentice-Hall Inc.

162 | Teknologi, Informasi, dan Komunikasí 
Kemendiknas. 2007. Peraturan Menteri Pendidikan Nasional Republik Indonesia Nomor 16 Tahun 2007 Tentang Standar Kualifikasi Akademik dan Kompetensi Guru. Jakarta : Kemendiknas.

Literacy 2005 Years 6 and 10, An Assessment Domain for ICT Literacy, http://www.iste.org/Libraries/PDFs/Australia_ICT_Assess ment.sflb.ashx/.(Diakses 2 Agustus 2014).

Marhaeni, A.A.I.N. 2012. Landasan dan Inovasi Pembelajaran. Singaraja: Universitas Pendidikan Ganesha.

Mayer, RE \& Moreno, R. 2010b. TechniquesThat Reduce Extraneous Cognitive Load and Manage Intrinsic Cognitive Load during Multimedia Learning. Dalam JL. Plass, R. Moreno, \& R. Brunken (Eds.). Cognitive Load Theory (hlm.131-149). New York: Cambridge University Press.

Mayer, RE. 2009a. Multimedia Learning: Prinsip-Prinsip dan Aplikasi. Terjemahan Teguh Wahyu Utomo. Yogyakarta: Pustaka Pelajar.

Mulyasa, E. 2005. Menjadi Guru Profesional Menciptakan Pembelajaran Kreatif dan Menyenangkan. Bandung: Remaja Rosda

Munir. 2008. Kurikulum Pembelajaran Berbasis Teknologi Informasi. Bandung: PT. Remaja Rosda Karya.

Munir. 2009. Kontribusi Teknologi Informasi Dan Komunikasi (TIK) dalam Pendidikan di Era Globalisasi Pendidikan Indonesia. Jurnal Pendidikan Teknologi Informasi dan Komunikasi 2. Negeri Yogyakarta.Nasioanalpengertiandan-manfaat-multimedia-pembelajaran), diakses 11 Nopember 2011.

163 | Teknologi, Informasi, dan Komunikasí 
Piaget, J. 1971. Psychologi and Epistemology. New York: The Viking Press.

Prawiradilaga, 2009. Prinsip Desain Pembelajaran, Jakarta: Kencana.

Prupuh Faturrohman dan Sutino Shobri. 2007. Strategi Belajar Mengajar. Bandung: Refika Aditama

Rusman. 2010a. Model-model Pembelajaran:Mengembangkan Profesionalisme Guru. Jakarta: PT Raja Grafindo Persada

Rusman. 2011b. Model-model Pembelajaran. Mengembangkan Profesionalisme Guru. PT.Grafindo Persada.

Rustam, K.R. 2011. Pembelajaran Berbasis TIK, Jakarta:Raja Grafindo Persada.

Sanjaya, Wina. 2008b. Strategi Pembelajaran Berorientasi Standar Proses Pendidikan (Jakarta: Kencana Prenada Media Group)

Sanjaya, Wina. 2006a. Pembelajaran dalam Implementasi Kurikulum Berbasis Kompetensi. Jakarta : Prenada Media Group .

Slamento .1998. Evaluasi pendidikan . Jakarta. Bina Aksara

Sudjana,Nana. 2010. Penilaian hasil proses belajar mengajar. PT Remaja Rosdakarya

Suparman. 1997. Desain Intruksional. Jakarta: Raja Grafindo Persada.

Surya, M. 2008. Potensi Teknologi Informasi dan Komunikasi dalam Peningkatan Mutu Pembelajaran di Kelas. (online). akses 13 Pebruari 2009. http://eko13.wordpress.com/2008/04/12/potensi-

164 | Teknologi, Informasi, dan Komunikasi 
teknologi-informasi-dan-komunikasi-dalampeningkatan-mutu-pembelajaran-di-kelas/

Suyanto, Kasihani K.E. 2009. Model Pembelajaran (Malang: Universitas Negeri Malang).

Tandeur Jo, etal. 2006. Curricula and the use of ICT in education: Two worlds apart, British Journal of Educational Technology.

Trianto. 2007a. Model-Model Pembelajaran Inovatif Berorientasi Konstruktivistik. Jakarta: Prestasi Pustaka

Trianto. 2009b. Mendesain Strategi Pembelajaran Inovatif Progresif. Jakarta: Kencana Prenada Media Group.

Trianto. 2010c. Mendesain Model Pembelajaran InovatifPrograsif. Jakarta : Prenada Media

Undang-Undang Republik Indonesia No. 12 Tahun 2012, Tentang Pendidikan Tinggi

Undang-Undang Republik Indonesia Nomor 14 Tahun 2005, tentang Guru dan Dosen

Undang-Undang Republik Indonesia Nomor 20 Tahun 2003, tentang Sistem Pendidikan

165 | Teknologi, Informasi, dan Komunikasí 


\section{BIODATA PENULIS}

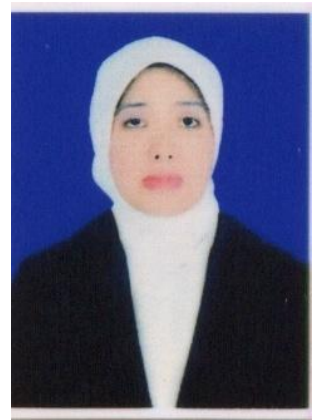

Eni Fariyatul Fahyuni adalah pengajar Fakultas Agama Islam, Universitas Muhammadiyah Sidoarjo yang mengampu beberapa mata kuliah diantaranya: profesi keguruan, ilmu kependidikan, bimbingan dan konseling, psikologi perkembangan, psikologi belajar, Kapita Selekta Pendidikan dan ICT pembelajaran. Putri ke-3 dari pasangan bapak $\mathrm{H}$. Ach. Fithon dan Ibu $\mathrm{Hj}$. Ismachu Djumroh ini lahir di Sidoarjo, 04 November 1978 yang mengawali kariernya sebagai konselor bimbingan dan konseling di SMK pada tahun 2011 hingga tahun 2014. Buku hasil karya yang sukses diterbitkan antara lain 1) Inovasi Model Pembelajaran Sesuai Kurikulum 2013; 2) Psikologi Belajar dan Mengajar; dan 3) Teknologi Informasi dan Komunikasi (prinsip-prinsip dan aplikasi). Latar belakang pendidikan yang digelutinya adalah sarjana Universitas Islam Negeri Sunan Ampel Surabaya Program Studi Psikologi (2011) kemudian dilanjutkan Pendidikan Islam Pascasarjana Universitas Muhammadiyah Sidoarjo (2013), dan saat ini penulis sedang menempuh studi Doktoral Program Studi Teknologi Pendidikan di Universitas Negeri Surabaya (UNESA).

166 |Teknologi, Informasi, dan Komunikasí 
167 | Teknologi, Informasi, dan Komunikasi 